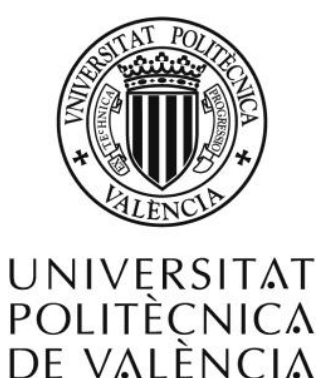

\title{
TABACO Y LITOGRAFÍA. LA LITOGRAFÍA COMERCIAL EN MÉXICO DURANTE EL SIGLO XIX. LAS ETIQUETAS DE CIGARROS Y PUROS
}

\author{
TESIS DOCTORAL \\ Departamento de Pintura \\ Facultad de Bellas Artes de San Carlos
}

Programa de Doctorado:

Artes Visuales: producción, gestión y restauración

Presentada por:

Laura del Carmen Mayagoitia Penagos

Dirigida por:

José Manuel Guillén Ramón

Enero de 2013 


\title{
AGRADECIMIENTOS
}

\section{A mi hijo: M. en C. en Servicio Exterior Juan Luis Espinosa Mayagoitia}

\author{
A mis padres \\ Gaspar Mayagoitia Barragán \\ Laura Penagos Martínez
}

A mi familia y amigos

\section{A la Universidad Politécnica de Valencia}

\section{Al Dr. José Manuel Guillén Ramón}

Su entrega a la docencia y a la dirección de alumnos del doctorado me ha permitido consultar investigaciones que son el producto de su asesoría y han dado luz a esta investigación.

El Dr. Guillén me ha acompañado e indicando generosamente el camino a seguir para concluir esta tesis. Aceptando ser mi asesor y compartir su talento. Sus consejos y compañía han sido eficientes, efectivos y oportunos. Superamos juntos a través de las nuevas tecnologías de comunicación los 9079 kilómetros que hay entre México y España. Siempre cerca. 
A los docentes que participaron en el Doctorado en Bellas Artes en la Ciudad de México por su entusiasmo, visión y por compartir los conocimientos que apuntalaron esta investigación:

\author{
Dr. Juan Bautista Peiró \\ Dr. Joaquín Aldás \\ Dra. Maribel Doménech \\ Dr. Elías Pérez \\ Dr. Juan Aliaga \\ Dr. Carlos Plascencia \\ Dra. Pilar Roig Picazo \\ Dra. Julia Osca Pons
}

\title{
A la Universidad Nacional Autónoma de México
}

Al Dr. Eduardo Báez Macías, en sus 51 años dedicados al trabajo académico y de investigación en Historia del Arte dentro de la Universidad Nacional Autónoma de México. Su trabajo incesante en los acervos de la Academia de San Carlos de México han permitido a muchos y grandes investigadores tener información fidedigna con relación a la Historia del Arte de los Siglos XVII al XIX, su interés y dedicación a la Historia de la Misión Carmelitana en México, las horas intensas en su labor docente pero sobre todo su consejo, su apoyo sin condiciones, su honestidad y el amor que expresa a cada alumno, a cada colega, en cada publicación nos obliga a realizar, tal vez no con su talento, pero a su manera, los resultados de investigaciones que permitan que el patrimonio de nuestro país continúe vivo.

Al Maestro Leo Acosta Falcón docente dedicado por más de 40 años a la litografía, por haberme dado la oportunidad de trabajar en 
su taller, bajo su dirección para conocer, ejercitar crear e imprimir las matrices litográficas. Su amistad, guía y consejo me han permitido valorar el esfuerzo que ha realizado por mantener vigente la técnica litográfica en la Academia de San Carlos de México.

- Escuela Nacional de Artes Plásticas

Acervo litográfico de la Escuela Nacional de Artes

Plásticas de la UNAM

- Facultad de Arquitectura de la UNAM

Archivo "Lino Picaseño" de la Facultad de Arquitectura de la UNAM

- Archivo General de la Nación

- Biblioteca del Instituto José María Luis Mora.

- Dra. Rocío Gamiño. Fototeca del Instituto de Investigaciones Estéticas. UNAM.

- Sr. Juan Pacheco: Encargado del acervo reservado de la Biblioteca "Lino Picaseño". Facultad de Arquitectura. UNAM.

- Lic. Filiberto García Solís responsable del acervo reservado de la Biblioteca "Samuel Ramos". Facultad de Filosofía y Letras. UNAM.

A quienes de alguna forma me apoyaron para realizar este proyecto.

....A cada una de las personas, instituciones e instancias académicas mi profundo amor y agradecimiento.

Qlaura del Gaxmen Slayagoitia Oenagos 
TABACO Y LITOGRAFÍA. LA LITOGRAFÍA COMERCIAL EN MÉXICO DURANTE EL SIGLO XIX. LAS ETIQUETAS DE CIGARROS Y PUROS.

INDICE

Pág.

INTRODUCCIÓN

HIPÓTESIS

OBJETIVOS

ESTADO DE LA CUESTION

ESTRUCTURA

METODOLOGIA

CAPITULO 1 LA ETIQUETAS DE CIGARROS Y PUROS

EN LOS ACERVOS ACADEMIA DE SAN CARLOS

Y LINO PICASEÑO

1.2 LOS ACERVOS

1.2.1 Piedras litográficas de la Academia de San Carlos

1.2.2 Imágenes de las etiquetas del Acervo Lino Picaseño. UNAM ENAP

CAPÍTULO 2 DEL ORIGEN DEL TABACO, USOS, CONSUMO Y OTROS ASUNTOS

2.1. EL CARÁCTER DIVINO DEL TABACO: MITO, RITO, 
2.1.1 El tabaco como medicina y como repelente

2.2. EL TABACO DURANTE LA CONQUISTA.

2.3 EL TABACO EN MÉXICO DURANTE EL SIGLO XVIII Y

LA PRIMERA MITAD DEL SIGLO XIX.

CAPITULO 3 EL TRABAJO PUBLICITARIO EN TORNO AL

TABACO

3.1 ¿EL ARTE DE FUMAR?

3.2 LA LITOGRAFÍA Y EL TEMA DEL TABACO

3.3 LAS ETIQUETAS COMERCIALES.

3.3.1 La evolución de la etiqueta como factor de publicidad

3.4 HABILITACIONES Y OTRAS IMÁGENES 
4.2 LA PRODUCCIÓN DE TABACO DURANTE LA GESTIÓN DE DÍAZ

4.4 LA LITOGRAFÍA EN AUXILIO DE LA LABOR COMERCIAL

CAPITULO 5 DESCRIPCIÓN DEL SISTEMA DE

CLASIFICACIÓN Y CATALOGACIÓN DE ETIQUETAS Y

PIEDRAS LITOGRÁFICAS

CAPITULO 6 CONCLUSIONES

DOCUMENTOS CONSULTADOS

ÍNDICE DE ILUSTRACIONES

Anexo 1 Registro fotográfico de la colección de piedras

Anexo 2 CD Sistema Mayaratacierraelpico 
Tobacco and Lithography. The commercial lithography in Mexico since the Nineteenth Century. Cigarettes and Havana cigars labels.

\begin{abstract}
Since the last thirty years of the Nineteenth Century, the tobacco enterprises printed their labels with a monochromatic lithographic technique which was introduced in Mexico by Claudio Linati at the Escuela de Bellas Artes de San Carlos in Mexico, and some time afterwards, by a chromolithographic technique.

Lithographic workshops were established little by little, and a growing amount of lithographers started working, drawing and printing labels.

Lithographers, who dedicated themselves to that type of work, set up their own workshops and some flourishing tobacco enterprises also established their own workshops.

The Ministry of Public Instruction and Fine Arts installed an Author's Registry Department for cigarettes and Havana cigar labels, in order to ensure the establishment of artistic property and avoid the use of false labels that were set on products that didn't belong to the original products signatures.
\end{abstract}

The Universidad Nacional Autónoma de México (UNAM) has more than one thousand lithographic stones as part of the heritage of the Escuela Nacional de Artes Plásticas, Academia de San Carlos and also keeps in a safe Lino's Picaseño heritage at the Faculty of Architecture. In that building there is an amazing amount of cigarette labels and a descriptive file for each one. At that time, the author's rights were registered in the Academia de San Carlos and afterwards, the files were sent to the Ministry of Public Instruction and Fine Arts, thus the labels have been preserved.

This thesis shows the relationship between lithography labels and tobacco products as a marketing media. As tobacco is a Mesoamerican product we present its history in México and have included the images showing tobacco as used at that time, in some pre Hispanic codex, up to the end of President Porfirio Diaz regime.

The photographs and digitalization for the Maya Catalog System, are those images of cigarettes and Havana tobaccos labels of the two consulted heritages. 


\title{
TABACO Y LITOGRAFÍA. LA LITOGRAFÍA COMERCIAL EN MÉXICO DURANTE EL SIGLO XIX. LAS ETIQUETAS DE CIGARROS Y PUROS.
}

\begin{abstract}
Resumen
Durante el último tercio del Siglo XIX, las empresas tabacaleras mexicanas imprimían sus etiquetas a partir de la técnica litográfica monocromática, que había introducido al país Claudio Linati en la Escuela de Bellas Artes de San Carlos de México y, posteriormente con la cromolitografía. Los talleres litográficos fueron desarrollándose poco a poco, y hubo cada vez más litógrafos que se dedicaron a dibujar o estampar las etiquetas. Algunas industrias, como la tabacalera, que estaba en auge, tenían sus propios talleres.
\end{abstract}

La Secretaría de Instrucción Pública y Bellas Artes instaló el registro autoral de etiquetas de cigarros y puros para asegurar los derechos de propiedad artística y evitar la falsificación de las que se colocaban en productos que no correspondían a las firmas originales.

La Universidad Nacional Autónoma de México conserva más de 1000 piedras litográficas en el acervo de la Escuela Nacional de Artes Plásticas, plantel Academia de San Carlos y también tiene resguardadas en el Acervo "Lino Picaseño" de la Facultad de Arquitectura, una cantidad impresionante de expedientes de diversos productos y más de doscientas etiquetas impresas de cigarros. El acervo se conservó gracias a los derechos autorales los cuales se tramitaban en la Academia de San Carlos y luego los expedientes se remitían a la Secretaría de Instrucción Pública y Bellas Artes para su registro.

En esta tesis se aborda principalmente la relación de la litografía como medio publicitario de etiquetas, habilitaciones y productos derivados del tabaco: cigarros y puros. Como el tabaco es un producto originario de Mesoamérica se presenta su historia en México, su representación en algunos códices prehispánicos y la evolución de la industria tabacalera hasta el final del porfiriato.

Se fotografiaron y digitalizaron los insumos para el sistema de catalogación Maya, son las imágenes de las etiquetas de tabacos y puros de los dos acervos consultados. 
La Escuela Nacional de Artes Plásticas de la Universidad Nacional Autónoma de México, cuenta con una colección de piedras litográficas que tienen grabadas diversas imágenes con etiquetas de cigarros, puros, cerillos, vinos, algunas historietas breves, etc. Fueron adquiridas en 1960 por el maestro Adolfo Mexiac, entonces Secretario de la Academia de San Carlos ${ }^{1}$.Tal parece que las etiquetas se imprimían en la Litografía Mercantil de México establecida en 1838, otras corresponden a la litográfica de el Buen Tono. Algunas piedras tienen imágenes por los dos lados, buen dibujo y grabado litográfico. Estas piedras pasaron del edificio de la Academia de San Carlos a la Escuela Nacional de Artes Plásticas de la UNAM, la profesora Martha Yáñez recuperó algunas imágenes y las imprimió. La pequeña muestra fue presentada en la exposición "Etiquetas y Empaques Litográficos del Siglo XIX" con motivo del bicentenario de la litografía, por el taller Claudio Linati de la UNAM, en 1998 y en la Sala del Sistema Tierra del Museo de Geología, exposición "Las piedras litográficas de Tlayua".

Una pequeña colección permanecía en el edificio de la Academia de San Carlos y posteriormente fueron retiradas hacia la parte trasera del estacionamiento ubicado en la calle de Academia No 22, estaban a la intemperie y a partir del año 2002

\footnotetext{
${ }^{1}$ Martha Yáñez, exposición "Etiquetas y Empaques Litográficos del S XIX" con motivo en el bicentenario de la litografía, por el taller Claudio Linati de la UNAM, en 1998; En la Sala del Sistema Tierra del Museo de Geología en la exposición "Las piedras litográficas de Tlayua”.
} 


\section{Som}

fue el motivo de mi proyecto de investigación inicié su limpieza, catalogación, impresión e historia.

El interés por el estudio de la litografía comercial surgió desde que cursé la Maestría en Historia del Arte en la Facultad de Filosofía y Letras de la Universidad Nacional Autónoma de México de 1998 al 2000. Me inscribí al curso de Técnicas y materiales e ingresé al taller del maestro Leo Acosta en donde ejercité la técnica litográfica. Observando algunos libros de litografía ${ }^{2}$, llamaron mi atención especialmente las etiquetas de cigarros y puros, algunas publicitaron productos de "La Principal" y "La Tabacalera Mexicana" ubicada cerca del ahora Museo de San Carlos, eran dos fábricas de cigarros y puros que imprimían sus etiquetas en la "Litográfica Mercantil de México" establecida desde 1838 hasta 1929. Estudié la historia de la litografía, sus funciones comerciales y plásticas, la importancia en la ilustración en obras históricas, geográficas y literarias. Obtuve el grado de Maestra en Historia del Arte con el tema de investigación: México en Miniaturas: El Atlas Pintoresco e Histórico de los Estados Unidos Mexicanos ${ }^{3}$.

\footnotetext{
2 Monumentos de México, Edición facsimilar de la que fue realizada por los establecimientos Massé y Decaen en México 1841, México, Fomento Cultural Banamex, 1989. Nación de Imágenes, Litografía Mexicana del Siglo XIX, México, el Equilibrista, MUNAL, 1994. Imágenes del Deseo. Arte y Publicidad en la Prensa Ilustrada Mexicana. UNAM, 2003.

${ }^{3}$ Laura Mayagoitia Penagos. México en Miniaturas. El Atlas Pintoresco e Histórico de los Estados Unidos Mexicanos de García Cubas. Tesis de Maestría en Historia del Arte. México, UNAM, 2002.
} 


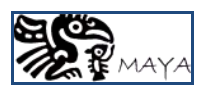

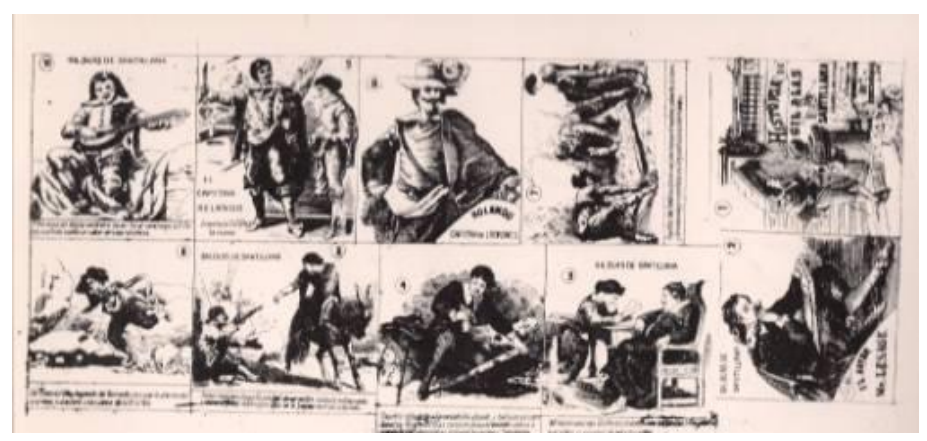

Figura 1 Gil Blas de Santillana. ENAP Colección de piedras litográficas Imp $^{\circ}$ Laura Mayagoitia. 2002

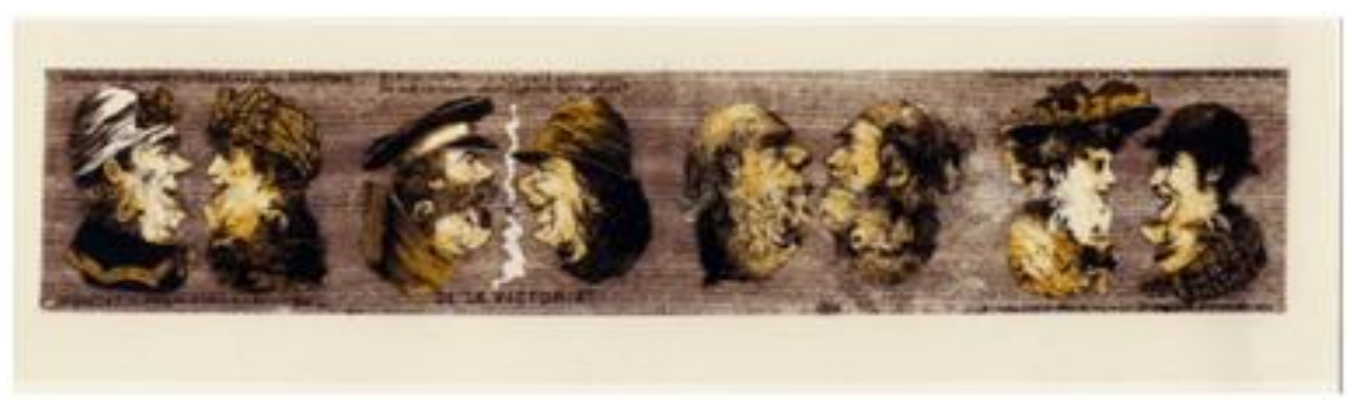

Figura 2 Etiqueta de cigarros "La Victoria" ENAP

Colección de piedras litográficas Imp $^{\circ}$ Laura Mayagoitia. 2002

Estudiar la producción comercial litográfica de cigarros y puros, encontrarme con las piedras de San Carlos, las colecciones de etiquetas ubicadas en el Acervo del Archivo General de la Nación y el acervo "Lino Picaseño" de la Facultad de Arquitectura de la UNAM y la formación que obtuviera con los cursos del Doctorado en Bellas Artes, me hicieron comprender la importancia de conservar el patrimonio artístico, que en el caso de las etiquetas impresas, es material frágil, debido a la poca calidad del papel en que se imprimieron, sin embargo las condiciones de conservación 
son buenas. En cuanto a las piedras, tienen el infortunio de haber sido manipuladas con descuido en diversas ocasiones durante su transporte desde plantel de la Escuela Nacional de Artes Plásticas Xochimilco al plantel Academia de San Carlos y viceversa, además presentan fisuras o fracturas debidas a su archivo incorrecto. Algunas han perdido tinta o ha desaparecido parte de la misma porque no se conservaron bien protegidas con goma arábiga, esto ha causado que se hayan engrasado, oxidado 0 cubierto de hongos.
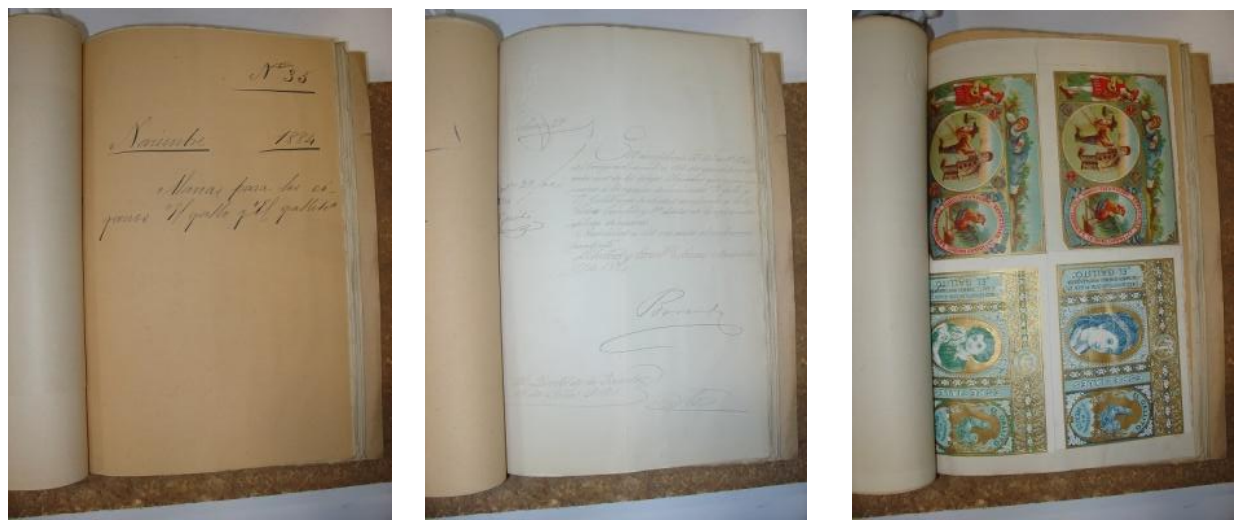

Figuras 3,4 y 5 Expediente de Registro de Autor. Para las marcas de cigarros El Gallo y El Gallito. Año1884 Exp. 35 (Fotografía L. Mayagoitia 2003)

Comprendí entonces que el material era valiosísimo para mi trabajo de investigación y me dirigí hacia esa fuente de información: Las etiquetas impresas de cigarros y puros del Acervo "Lino Picaseño". Procedí a realizar el registro fotográfico de cada etiqueta y su respectivo expediente, página por página. Después observé que aún cuando el material esta registrado en la obra del Dr. Báez Macías Guía de la Academia de San Carlos, no existe un archivo digitalizado de la impresionante colección. Este 
fue el motivo por el cual me he dedicado a realizar un sistema de clasificación y catalogación que permita manejar el material virtualmente y aporte la posibilidad a otros investigadores para profundizar en este tema.

Durante mi proyecto de investigación para la Universidad Politécnica de Valencia, inicié la limpieza de las piedras, catalogación e impresión, para determinar el objeto de estudio e iniciar la tesis doctoral y debido a que son más de 1200 piedras y por lo menos el cuádruplo de imágenes, fue necesario elegir aquellas que deseaba historiar, por lo tanto seleccioné las que abarcan el tema del tabaco. Ya avanzada la catalogación seleccioné 62 imágenes de las más bellas de cigarrillos y puros e hicimos con el apoyo del alumno Claudio Romo (Chileno) algunas impresiones en papel algodón y un video en el que abordamos la técnica de recuperación de imágenes. Con este avance participé en el Primer Congreso Internacional sobre "Arte y Cultura siglo XIX al XXl" organizado por la Benemérita Universidad Autónoma de Puebla. Puebla, México 14 al 18 de noviembre de 2005, dictando la conferencia "Las etiquetas comerciales en el siglo XIX" y publiqué en el Periódico Metlalpilli de la Facultad de Filosofía y Letras. Ciudad Universitaria, Año III. Número 23, Mayo de 2006. "Las etiquetas de tabacos durante el porfiriato".

He podido apreciar como la tradicional técnica litográfica que fue utilizada en sus orígenes comercialmente, ha sabido recuperarse y mantenerse a través de escuelas y artistas como un 
medio de expresión de gran versatilidad, creándose centros y talleres dedicados al medio como Mourlot o Desjobert en Francia, Quensen en Alemania; Polígrafa, Don Herbert, Antonio Gayo o "6A" en España, el Tamarind Workshop en Albuquerque, Nuevo México, y en la Escuela Nacional de Artes Plásticas de la UNAM en los talleres "Claudio Linati" con la Maestra Martha Yáñez y Leo Acosta en el plantel Academia de San Carlos entre otros.

\section{HIPOTESIS}

Si se estudia la importancia del tabaco desde la época prehispánica hasta el porfiriato destacando su utilización, comercialización, importancia artística e histórica, a partir del registro fotográfico de los materiales litográficos e impresos podremos estructurar un sistema digitalizado que al ser divulgado, facilite la catalogación de la información e imágenes para que sean utilizados en investigaciones posteriores, de manera sencilla sin dañar el material original.

\section{OBJETIVOS}

Objetivo general

Estructurar un sistema digitalizado que permita facilitar la catalogación y manejo de los materiales litográficos e impresos a partir del estudio de la historia del tabaco, su importancia, y el registro fotográfico del material ubicado en diversos acervos mexicanos. 


\section{Objetivos específicos}

1.-Estudiar la importancia del tabaco desde la época prehispánica hasta el final del porfiriato.

2.-Seleccionar las imágenes relativas al tabaco, etiquetas para puros, vitolas etc., contenidas en las piedras litográficas del Acervo de la Academia de San Carlos de México.

3.-Seleccionar las imágenes relativas al tabaco, etiquetas para puros, vitolas etc. ubicadas en el Acervo "Lino Picaseño" de la Biblioteca de la Facultad de Arquitectura de la UNAM.

4.-Realizar registros fotográficos de las piedras con imágenes dibujadas o grabadas de etiquetas de tabacos y puros (Academia de San Carlos).

5.-Realizar registros fotográficos de los expedientes de Propiedad Artística relacionados con las etiquetas de cigarros y puros en el acervo "Lino Picaseño".

6.-Capturar en un video breve datos sobre la técnica litográfica.

7.- Desarrollar un sistema digitalizado del material fotografiado.

\section{ESTADO DE LA CUESTION}

La litografía había sido inventada en Munich por Alois Senefelder, inició sus investigaciones sobre esta técnica en 1796, poniéndola a punto y patentándola en 1798.

La introducción de la litografía en México por Claudio Linati (1790-1832) data de 1825 y la enseñanza de la técnica inició en la Academia de San Carlos de México, durante la dirección de Pedro Patiño Ixtolinque, siendo el primer profesor de litografía Ignacio 
Vicente Serrano. Esta técnica se popularizó en los talleres litográficos mexicanos que publicaron mapas, etiquetas, viñetas, imágenes para ilustrar textos literarios, religiosos, imágenes costumbristas, personajes célebres, pagarés, boletos, etc. A través de los impresos podemos tener una visión del tema de diseño gráfico comercial en México del siglo XIX.

La utilización de la litografía en el ámbito comercial mexicano permitió publicitar gran cantidad de productos porque era una técnica versátil, más rápida y económica, logrando grandes tirajes de impresión en comparación con otras técnicas, además se combinaban fácilmente textos e imágenes, la utilización del color era más sencilla y a muy bajo costo. Al principio, las imágenes y viñetas eran generalmente importadas de España, Francia, o de Inglaterra y la tipografía se les fue adaptando de acuerdo al mensaje escrito que permitiera invitar a consumir los productos. En las etiquetas poco a poco se fueron incluyendo dibujos de artistas mexicanos. Fue a partir de 1923 cuando la litografía se utilizó con fines plásticos en la Escuela Central de Artes Plásticas, con Francisco Díaz de León, Carlos Mérida y Gabriel Fernández Ledesma y en el Taller de la Gráfica Mexicana. Hacia 1929 las fotomecánicas comenzaron a descartar el uso de piedras en litografía, sustituyéndolas por planchas de zinc o aluminio como fuente de reproducción de imágenes en el ambiente empresarial y muchas de las piedras desechadas, pararon en construcciones, o fueron vendidas en mercados como piedras para afilar cuchillos. 
Comprendo que en el mundo, la litografía es un campo de investigación vasto y estudiaremos particularmente las etiquetas de cigarros y puros durante el final del siglo XIX y principio del XX cuya factura aparece de forma paralela al desarrollo histórico de mi país. La fecha de impresión y especialmente las imágenes nos remontan a momentos heroicos, personajes históricos, tipos étnicos que no están lejanos al estilo de pensamiento del pueblo que vivía el porfiriato ${ }^{4}$ periodo cuyo objetivo político, una vez lograda la estabilidad social, era presentar a México como una nación independiente y libre con grandes posibilidades para atraer a los inversores de otros países y lograr el desarrollo económico. En este sentido podemos relacionar las imágenes con algunos hechos históricos relevantes, detectar algunas intenciones como invitar al pueblo para comprar cigarros o puros, relacionando las imágenes y la información escrita en las etiquetas con la ideología de las diversas capas sociales consumidoras de estos productos, para quienes era fundamental al adquirir los cigarros, leer algunos datos contenidos en las etiquetas como: la marca, fábrica, medidas, costo, mensajes y ver las imágenes que las conformaban. El trabajo de campo, las imágenes y la lectura de las leyendas contenidas en las etiquetas, me llevaron y motivaron a estudiar ese periodo histórico y su relación con el tabaco.

En España y en México se han escrito algunas obras que abordan el tema de la estampería litográfica y nos presentan información relevante en torno a las obras producidas durante el

\footnotetext{
${ }^{4}$ Porfiriato. Es el periodo de gobierno del Presidente mexicano Porfirio Díaz. 18801910. El país entró en una fase capitalista definida por la industrialización.
} 
siglo XIX y principio del XX. Tres tienen como característica común haber sido el resultado de tesis doctorales en las áreas de Historia del Arte o Bellas Artes. A continuación haré mención de ellas.

Litografía Industrial en el norte de España de 1800 a 1950 de Concepción Lidón Martínez, nos muestra aspectos históricos que envolvieron el descubrimiento de la técnica, su difusión en Europa e incorporación a la industria gráfica española especialmente en el Litoral Cantábrico. Su discurso de lo general a lo particular aborda la situación socioeconómica de Europa hasta llegar a España y concentrarse en el litoral. Parte de la importancia de la Revolución Industrial y utilización de nuevas máquinas que propiciaron el desarrollo de la producción industrial y el auge manufacturero, el progreso técnico y científico a partir del siglo XVIII que obligó la migración del campo a las ciudades conformando ejércitos aliados a la producción industrial aprovechando las naciones europeas la red financiera a partir de la extracción de materiales preciosos de América y el comercio con otros continentes.

La arquitectura, hasta entonces considerada Arte, pasa a ser obra de ingeniería funcional práctica y se utilizan nuevos materiales de construcción a partir del desarrollo o de hierro colado, vidrio y cemento que desplazan a la madera y adobe. Se construyen grandes museos, universidades bibliotecas etc., con un distinto sentido estilístico y arquitectónico.

En este contexto la autora aborda el auge de las artes plásticas en donde la litografía como técnica de impresión, aportó 
un estilo distinto de información, una síntesis entre lenguajeimagen atractiva para la burguesía capitalista que eran consumidores de productos un tanto superfluos como el tabaco. Desarrolla el tema de las condiciones que llevaron Senefelder a descubrir y perfeccionar su técnica en 1796, resalta su constancia como estudioso de la química, y de la estructura de materiales hasta obtener reconocimiento con base en su productividad. La técnica fue descrita en publicaciones traducidas a partir de escritos de Marcel de Serres editadas en julio de 1815 y marzo de 1816 en el periódico Memoria de Agricultura y Artes de la Real Junta de Comercio de Cataluña en la sección de mecánica. En 1815 las prensas tenían sistemas automatizados para humedecer, limpiar y cargar la piedra y en 1833 ya contaban con motor de vapor, las cilíndricas, etc. y no escapan de la obra los fabricantes de tintas alemanas que las comercializaron hacia España, Francia y el Continente Americano. La difusión rápida de la técnica principalmente en Cataluña, Barcelona y Tolosa a partir de 1819 se logró por el intercambio de litógrafos extranjeros para difundir la técnica en España y el envío de artistas españoles a Francia y Alemania para aprenderla.

Es así como las carpetas con estampas litográficas, los paisajes de monumentos españoles, realizados por artistas españoles, empezaron a difundirse por todos los lugares de Europa y considero que también en América. Los ilustradores gráficos y extranjeros dedicados a retratar la vida regional del siglo XIX, comprometieron sus obras en publicaciones románticas 
prestigiadas como El Artista (1835), revistas pintorescas, viajes pintorescos, guías históricas y descriptivas etc.

Concepción Lidón nos aproxima, poco a poco a la litografía y su desarrollo en el Litoral Cantábrico, en donde desde 1868 se publicaron revistas periódicas, folletos de propaganda y otras publicaciones que permanecieron vigentes desde la Revolución 1868 hasta 1950, cuando el offset y los nuevos sistemas de impresión la desterraron de la circulación.

La autora, considera que la cercanía del país Vasco y Cataluña con Francia propició que las litográficas privadas o en pequeña escala del Litoral Cantábrico fueran pioneras de la industria gráfica española y lograran que la técnica se difundiera en las provincias. El libro presenta cuadros precisos con la cronología de los establecimientos litográficos, los propietarios de los talleres, el tipo de impresos que publicitaban y la manera en que los talleres litográficos españoles, su técnica y estilos repercutieron en América a través de sus filiales.

En España el Real Decreto del 20 de noviembre de 1850 obligó el uso y propiedad de marcas de distintas fábricas inclusive el anuncio publicitario y el tema de la pequeña estampería, hojas de correspondencia, papel empréstito, prospectos, tarjetas de visita, cajas de cerillos, etiquetas de productos envasados, vitolas, cigarros y puros, estampas religiosas etc. La Dra. Lidón considera importante reconocer el valor del análisis estilístico de la pequeña estampería salida de los talleres del litoral en los que el lenguaje escrito e icónico produce una sintaxis sensitiva a través de nuevos significantes formales y nuevas formas de articularlos en el 
espacio plástico. Considera que se definen dos patrones en los modelos compositivos de estamperías pequeñas: el primero en el periodo romántico delimita excesivamente los espacios que corresponden al texto y a la imagen. Cada uno cubre áreas de información de diferente manera y espacios plásticos distintos: en ocasiones el texto y la imagen aparecen inscritos en una orla y en otras el texto aparece en un espacio limitado, mientras que la imagen se distribuye con libertad por toda la superficie plástica. El segundo durante la última década del siglo XIX emplea de manera masiva los elementos decorativos. El texto se integraba en el espacio plástico de la ilustración gráfica, convirtiéndose en un importante elemento decorativo, a la vez que suministraba a la imagen un contenido informativo complementario. Texto e imagen continuarán cubriendo áreas de información diferentes. El texto definía el anuncio, enumeraba y facilitaba los datos, proporcionaba información más elaborada y sintética utilizando un código que se fundamenta en el empleo de la lengua. La ilustración en cambio es el motivo de atención plástica del carácter afectivo, dirigido a los sentidos provocando sentimientos en el receptor.

Dentro del criterio técnico la Dra. Lidón aborda la temática relacionada con las matrices litográficas: piedras calizas y planchas metálicas de zinc o aluminio, procedimientos de dibujo manuales, pruebas en matrices de zinc y posteriormente aluminio. Como en 1855 Poitevin pone a punto la aplicación de la fotografía a la litografía, haciendo más accesible la reproducción de imágenes fotográficas con tintas grasas, y como se producen a 
finales del siglo XIX importantes avances en el uso de la fotolitografía y e fotograbado. Ya en el siglo XX, la utilización del offset, técnica industrial derivada de la litografía, permitió el uso de planchas emulsionadas, menos pesadas, que podían ser colocadas en máquinas rotativas, esto hizo que fuera quedando en desuso la utilización de piedras litográficas en la litografía industrial, quedando estas matrices relegadas a la litografía artística.

Considero que el análisis y la forma de presentar los temas de manera organizada y precisa, es en lo que radica el mérito de la obra de la Dra. Lidón ha escrito un texto que nos permite ver, con claridad, lo que sucedía ayer y entonces y comparar a través de sus ejemplos, el desarrollo de la litografía comercial en México durante el siglo XIX. En general, Concepción Lidón opina que la litografía como técnica surgió gracias a la evolución y divulgación de la ciencia y la tecnología en Europa, y entre España y México observamos que existen coincidencias y divergencias en tanto a su introducción y desarrollo.

La técnica litográfica llegó a México con el experto Linati en 1825, después fueron trasladadas sus prensas por barco desde Italia hacia Veracruz para iniciar la práctica litográfica en la Academia de San Carlos, dentro del taller del Gral. Serrano. Sin embargo motivo de otro estudio sería encontrar la vinculación entre las litográficas españolas y las que fueron estableciéndose en México especialmente la Litográfica Catalana, Litográfica 
Española y otras cuyos propietarios presumiblemente tendrían origen ibérico.

Otra obra importante para mi investigación es Imágenes del deseo ${ }^{5}$, de Julieta Ortiz Gaitán quien realizó un análisis de la imagen publicitaria en la prensa ilustrada mexicana durante el periodo 1884 - 1932. La publicación evidenció la ausencia de un estudio sobre la imagen publicitaria en la prensa mexicana desde una perspectiva historiográfica rigurosa, que hiciera énfasis en los valores plásticos y su importancia como documento histórico, desde el desarrollo de las artes visuales de México en el siglo XX.

La autora consideró un corpus iconográfico de 900 anuncios publicados en la prensa ilustrada en México: Revistas como El Mundo seminario ilustrado (1884-1900) El Mundo Ilustrado (1900-1914), Revista Moderna (1898-1911), Álbum de damas (1907-1908). El tiempo ilustrado (1893-1912), Arte y Letras (1904-1912), México Actual (1913), México, Revista Ilustrada (1915-1917), Multicolor (1911-1914), Arte Gráfico (1919-1923), Revista de Revistas (1910- a la fecha) El Universal Ilustrado (1917-1941). Durante el periodo que abarca, en la investigación afirma que los grandes acontecimientos históricos y transformaciones sociales en México, fueron reproducidos mediante la imagen publicitaria que fue consecuencia directa del proceso de reproducción mecánica, desarrollada en la segunda mitad del siglo XIX. Este proceso incide en la divulgación del

\footnotetext{
${ }^{5}$ Julieta Ortiz Gaitán. Imágenes del Deseo. Arte y Publicidad en la prensa ilustrada mexicana (1894-1939) México, UNAM, 2003
} 
nuevo lenguaje visual, público, urbano. La autora describe y analiza la proliferación iconográfica tanto en los muros de las calles, como en las páginas de la prensa ilustrada, que corresponde a un nuevo lenguaje visual propio de las sociedades urbanas del siglo XX. En el texto, se identifican los estilos y la presencia del desarrollo formal de las artes plásticas del siglo XX "Los primeros anuncios se ubican en un complejo panorama del modernismo con las exuberancias del academicismo tardío y el florecimiento del art nouveau, hasta transitar a los estilos geométricos de los años veinte y treinta, inspirados por la nueva modernidad del art decó y el racionalismo purista" ${ }^{6}$. El relato inicia con el resplandor del porfiriato cuando el presidente Díaz logró la modernización en las estructuras social y económica, sueño que concluyó en 1910 violentado por la crisis nacional que provocó la desestabilización de la nación mexicana.

La Dra. Gaitán comenta que la democratización de la imagen es un fenómeno cercano a la idea del progreso propio de la modernidad, que involucra a la litografía y a la fotografía por la fidelidad como se refieren los eventos y la gran cantidad de imágenes reproducidas. Entre los fines que se perseguían a través de las imágenes, menciona la adquisición de bienes y objetos para posesión o consumo de la sociedad capitalista que surgió a partir de la revolución industrial que a la vez se conforma por los cambios que provocaron las máquinas, la producción en serie y la aparición de las grandes fábricas. Entonces el mercado

\footnotetext{
${ }^{6}$ Julieta Ortiz Gaitán Op. Cit. p. 19
} 
se vio inundado por bienes manufacturados a nivel artesanal que insertos en una producción masiva necesitaba canales adecuados para su distribución y venta y también dispositivos que estimularan su adquisición y consumo.

Otro texto interesante es el de la Dra. Thelma Camacho Morfín. Escribió -como resultado de su tesis doctoral Imágenes de México. Las historietas del Buen Tono de Juan B. Urrutia 1909-1912. Las imágenes estudiadas fueron dibujadas e impresas en la litográfica de la fábrica de tabaco el Buen Tono establecida en 1892, en donde por primera vez, se engargolaron los cigarros de manera mecánica. Esta empresa era tan próspera que creó una colonia cercana a la fábrica donde vivían los trabajadores.

"La publicidad era una actividad vital para el Buen Tono ya que los cigarros no son un producto de primera necesidad y, en esa época, los fumadores estaban habituados a fumar picadura de hoja, producto del uso tradicional muy accesible y económico, que no era objeto de la producción industrial “7

El taller litográfico e imprenta del Gran Tono fueron empresas importantes durante la tercera década del XIX que reproducían ilustraciones de libros periódicos y empaques de las mercancías e imágenes publicitarias. Los dueños estaban seguros de que podían descalificar a la competencia a través de la publicidad, convenciendo al público de la calidad de sus productos y

\footnotetext{
${ }^{7}$ Thelma Camacho Morfín. IMÁGENES DE MEXICO. LAS HISTORIETAS DE EL BUEN TONO DE JUAN B. URRUTIA 1909-1912 p. 20
} 
demostrándoles que el tabaco industrializado era mejor y más higiénico. ${ }^{8}$ El taller tenía infinidad de piedras litográficas.

El Buen Tono producía gran cantidad de marcas de cigarros: Reina Victoria (1908) Alfonso XIII (1908) Héroe de la Paz (1909) Elegantes, Superiores, y Jockey Club La parisienne, Turcos, Eclipses, Chorritos, elaborados con papel chorrito (1895) Canela Pura con papel canela (1901) Flores de Arroz con papel arroz. Otros cigarros estaban dirigidos al consumo de las mujeres: Gardenias y Margaritas, La Popular o la Mascota.

Uno de los litógrafos más importantes del Buen Tono fue Juan Bautista Urrutia nacido en la ciudad de México en 1871 o 1872. A los 16 años ingresó al Taller Montouriol, luego varios años más tarde trabajó en la Litografía Latina establecida en Arcos de Belén desde 1889. Fue un dibujante irónico, ingresó al Buen Tono cuando tenía 27 años y allí permaneció hasta su muerte en 1938. Nunca firmó sus litografías, y curiosamente tenía fobia al tabaco, producto que publicitó casi 40 años. En el periódico El Imparcial en 1896 aparecían las historietas de El Buen Tono, abordaba en principio temas cotidianos argumentos sencillos y los personajes tenían nombres comunes (Fig. 6). Las historietas no estaban dirigidas especialmente al público infantil pero eran ellos los que más las leían. En este libro la autora da cuenta de las historietas realizadas en la fábrica de tabaco, el contexto que el autor narraba en las historietas, los personajes y 
los eventos políticos, históricos y de la vida cotidiana que irónicamente relataba.

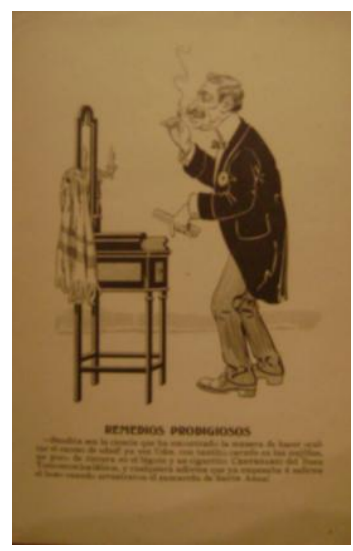

"Bendita sea la ciencia que ha encontrado la manera de hacer ocultar el exceso de edad! Ya ven ustedes, con tantito carmín en las mejillas, un poco de tintura en el bigote y un cigarrito CENTENARIO del Buen Tono entre los labios, y cualquiera adivina que ya empezaba a salirme el boso cuando arrestaron a zancarrón de Santa Anna!"

Figura 6 REMEDIOS PRODIGIOSOS

Urrutia. Litográfica y Fábrica de Cigarros del Buen Tono.

Museo del Estanquillo. Acervo Carlos Monsiváis México D.F.

Urrutia creó una serie litográfica en contra de la realidad posrevolucionaria en "Las maravillosas aventuras de Ranilla", sus historietas se difundieron de 1904 hasta 1914 y algunas en $1922^{9}$. El Imparcial imprimió a primera colección del 7 de mayo de 1905 al 29 de septiembre de 1907 entonces Urrutia numeró las historietas en colecciones de 100. Los productos del Buen Tono alcanzaron premios en las exposiciones internacionales de París 1900, St. Louis Missouri 1904, exposiciones internacionales, medallas de oro en Londres (1889), en Búfalo (1895) y Guatemala (1907). La fábrica de cigarros anunciaba en 1908, que la Real Casa de España la había nombrado proveedora oficial de tabaco; a partir de entonces, Alfonso XIII se convirtió en un personaje muy recurrente en las marcas de cigarros y por supuesto en las etiquetas litográficas.

\footnotetext{
${ }^{9}$ Ibidem p. 24
} 


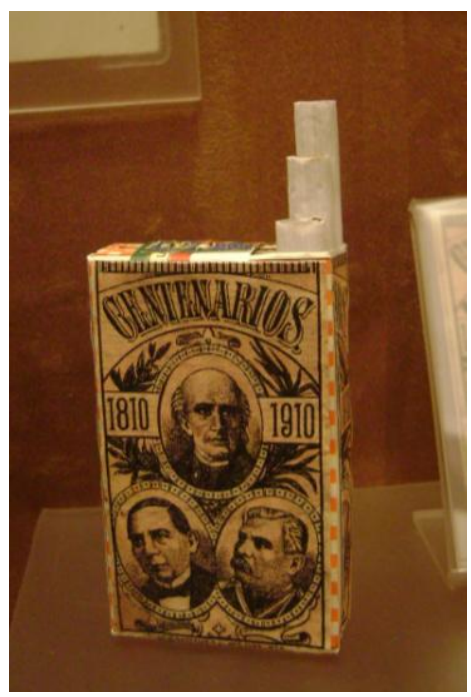

Figura 7 Etiqueta de cigarros CENTENARIOS 1810-1910 Litografía del Buen Tono. Museo del Estanquillo. Acervo Carlos Monsiváis

Urrutia realizó historietas y muchas etiquetas para cigarros y puros, desafortunadamente no hemos podido dar fe de que la factura le corresponda debido a que nunca las firmó; los derechos pertenecían a la Cigarrera del Buen Tono. En esta obra podemos encontrar con precisión el vínculo entre litografía y tabaco.

Florencio Giménez Caballero y Manuel López Rodríguez presentan una obra dedicada principalmente a la vitolfilia: Cien Anillas de Calidad en la Litografía Tabacalera ${ }^{10}$ en la que determinan el concepto de calidad para seleccionar las vitolas o anillos para puros y expresan de manera sucinta la importancia de la litografía como técnica de impresión y su aplicación en las vitolas que eran conmemorativas, hacen hincapié en el establecimiento de los talleres alemanes, ingleses, italianos y

\footnotetext{
${ }^{10}$ Florencio Giménez Caballero y Manuel López Rodríguez. Cien Anillas de Calidad en la Litografía Tabacalera. Sevilla, Giralda, 1998.
} 
españoles que aplicaron esta técnica y se fueron estableciendo en la isla de Cuba durante el siglo XIX, en donde realizaron anillas por encargo de los dueños de las fábricas de puros. Este libro nos ha proporcionado valiosa información sobre las "habilitaciones" que son diversas etiquetas que se colocan en las cajitas para puros. Presenta una colección de 100 vitolas, de las cuales 10 se refieren a empresarios tabacaleros establecidos en México. Es muy importante para mi investigación la información que nos proporcionan sobre las marcas de tabacos, los dueños de las fábricas, su ubicación y las compañías litográficas que las imprimieron.

\section{ESTRUCTURA}

En el primer capítulo de la tesis presento el método de investigación, los acervos consultados y su importancia, el interés que reporta estudiar las piedras y las etiquetas de cigarros y puros, se reportan las imágenes de la colección de piedras seleccionadas de la Escuela Nacional de Artes Plásticas, Plantel Academia de San Carlos de México.

Como historiadora de arte me sentí motivada a incluir en esta investigación un estudio y análisis de la importancia del tabaco y su uso desde la época prehispánica hasta el porfiriato así el capítulo 2 hace referencia al tabaco durante la época prehispánica, su carácter divino representado en algunos códices mexicanos, los usos ceremoniales, médicos y el descubrimiento que hicieran de esta planta y la costumbre de fumar los primeros españoles que llegaron a México. Se ofrece el estudio del 
desarrollo de las fábricas durante la época colonial y algunas costumbres en la sociedad novohispana, relacionadas con el consumo del tabaco, la época independiente con la participación de las mujeres en la manufactura de los cigarrillos y su problemática como obreras. Acompañan al texto de este capítulo algunas imágenes de códices, pinturas y litografías tanto costumbristas, como de etiquetas de puros y cigarros.

Presento, en el Capítulo 3, el trabajo publicitario en torno al tabaco con el objetivo de dilucidar si la acción de fumar fue considerada un arte o si en realidad se representó a través de imágenes litográficas en el marco publicitario del tabaco. Abordo la historia de las etiquetas hasta llegar a las comerciales y el registro de propiedad artística que se estableció durante el siglo XIX en México. En este entorno surge la impresión litográfica de etiquetas de cigarros y puros como apoyo para publicitar estos productos y hacerlos atractivos para los compradores atrayendo al público, masculino y femenino de acuerdo al tipo de imágenes dibujadas y los textos que inducían la acción de fumar, la calidad de los productos, el costo, el prestigio de los fabricantes y comerciantes. Así estamos en condiciones de relacionar la imagen, el tabaco, los productos derivados y los consumidores.

En este sentido cobró importancia la producción del tabaco, el desarrollo de la litografía comercial con grandes casas litográficas como la Litográfica Mexicana, La Catalana, Litográfica Española, Debray, Mountauriol etc., en donde trabajaron artistas plásticos de la talla de Posada, Casimiro Castro, Urrutia, y otros y con la aparición de las grandes fábricas de papel que apoyaron la 
fabricación de cigarrillos y de etiquetas comerciales más finas. La competencia de los productos, y la producción de etiquetas que los publicitaron dieron origen al Registro de propiedad autoral, conservándolas en el archivo de la entonces Academia de Nobles Artes de San Carlos en México, los documentos están actualmente bajo resguardo en la Biblioteca "Lino Picaseño" de la Facultad de Arquitectura de la Universidad Nacional Autónoma de México.

En el capítulo 4 resalta el tema del Porfiriato que exalta la figura del General Díaz quien asumió la presidencia de mi país por 30 años, el tema del tabaco fue recurrente, durante su gestión tanto en la economía, como en el arte.

El capítulo 5 recoge el trabajo de campo, es aparentemente el más pequeño sin embargo, es sobre el que recae la organización, selección, fotografía, de: a) piedras litográficas las imágenes grabadas en las piedras que ilustran la invitación a fumar, presentan datos diversos: en ocasiones hacen alusión a la marca, presentan el nombre de la casa litográfica, otras tienen anotada la dirección del establecimiento comercial que expendía los cigarros y puros, su costo y registro.

b) Etiquetas de tabacos y puros, en las que se escribían: Marcas, las ciudades a las que se enviarían las etiquetas, son diversos y los conceptos utilizados en las etiquetas, para publicitar el producto e invitar a su compra. Las marcas referían personajes célebres, lugares pintorescos, desarrollo tecnológico, etc. La calidad del tabaco y su forja, determinaban el costo de los productos y el tipo de consumidores. Muchas etiquetas de 
cigarros al mismo tiempo formaban parte del embalaje. En el caso de los puros, las imágenes corresponden a la etiqueta que se colocaba sobre la caja de puros, dentro de ella o en las vitolas ovaladas, rectangulares, circulares, formatos de recibos y pagarés, etc. En el último capítulo presentaré las conclusiones.

\section{METODOLOGIA}

- Recopilación y análisis de documentación escrita y gráfica.

- Catalogación, limpieza, impresión y fotografía de piedras litográficas de la ENAP Academia de San Carlos.

- Registro fotográfico de los expedientes que corresponden a las etiquetas de tabacos y puros del Acervo Lino Picaseño (Facultad de Arquitectura)

- Diseño y alimentación del programa "Mayaratacierraelpico": fotografías de las imágenes grabadas en las piedras litográficas, las etiquetas de tabacos y puros y documentos (expedientes) que amparan su registro autoral. 


\section{CAPÍTULO 1 LAS ETIQUETAS DE CIGARROS Y PUROS EN LOS ACERVOS "ACADEMIA DE SAN CARLOS DE MÉXICO" Y "LINO PICASEÑO"}

El trabajo que presento tiene como objetos de estudio las piedras litográficas de la colección de la Escuela Nacional de Artes Plásticas y las etiquetas de cigarros y puros del Acervo "Lino Picaseño" en la Facultad de Arquitectura, ambos pertenecen a la Universidad Nacional Autónoma de México.

\subsection{LOS ACERVOS}

El acervo litográfico de la Academia de San Carlos de México, pertenece a la Escuela Nacional de Artes Plásticas y se ubica en el centro histórico, en la calle de Academia 22. En tanto el acervo "Lino Picaseño se ubica en la Biblioteca de la Facultad de Arquitectura de la Universidad Nacional Autónoma de México, dentro de la Ciudad Universitaria. Para acceder a ambos solicitamos permisos y la entrega del proyecto de investigación con el compromiso de donar un ejemplar de la tesis y del material fotográfico organizado en un sistema automatizado.

1.2.1 Piedras litográficas de la Academia de San Carlos.

El primer grupo de etiquetas comerciales dibujadas y grabadas sobre piedra, constituyen parte del acervo de piedras litográficas de la Escuela Nacional de Artes Plásticas ubicadas en el plantel Academia de San Carlos. Inicié en el año 2002 la limpieza y el 
registro fotográfico de casi 200 piedras, cada piedra tiene de 3 a 6 imágenes con etiquetas comerciales, las piedras no estaban acomodadas por temas, estaban amontonadas en columnas de 20, cada una pesa de 7 a $10 \mathrm{~kg}$ y mide aproximadamente $30 \times 45 \times 6 \mathrm{~cm}$, estaban cubiertas con polvo y algunas con hongos. Como las tomas de agua estaban alejadas del taller fue necesario solicitar que se adaptara una que estuviera cercana, debido a estos problemas pude seleccionar pocas piedras relacionadas con el tabaco, cigarros y puros. Para manejar las piedras desde la limpieza hasta la fotografía se hacen aproximadamente 24 movimientos por cada una y conté con cinco personas que me ayudaran a cargarlas, lavarlas utilizarlas para imprimir, protegerlas con goma arábiga y meterlas en estuches de cartón.
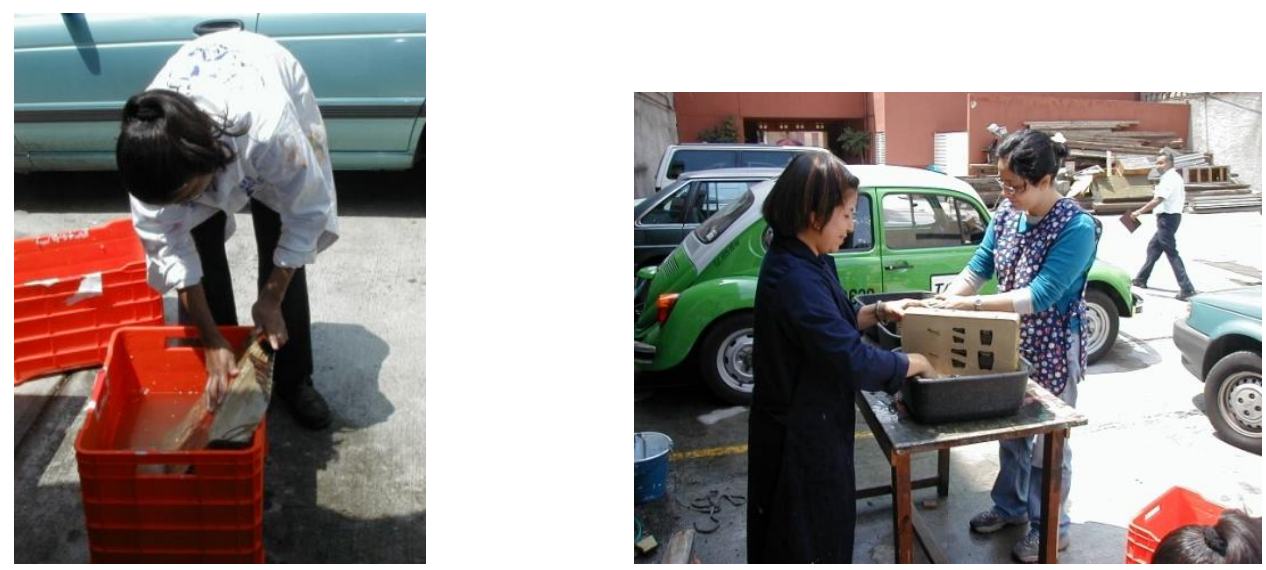

Figuras 8 y 9 Lavado de piedras. Becarios de la Maestría en Artes Plásticas. Estacionamiento de la Academia de San Carlos. México.

El trabajo duró dos años y tuvo que ser suspendido. En 2007 pude volver a revisar más piedras y hacer algunos registros más. El trabajo realizado en San Carlos y la recuperación de piedras e imágenes dio pauta para que en ese año varios alumnos de la ENAP 
empezaran a realizar trabajos de investigación para exámenes de licenciatura en el área de grabado y litografía.

El acervo litográfico cuenta con imágenes de etiquetas de caricaturas, historietas, etiquetas de vinos, café, conservas, chocolates, cerveza, puros, cigarros, cerillos, medicamentos, etc. Presento dos ejemplos:

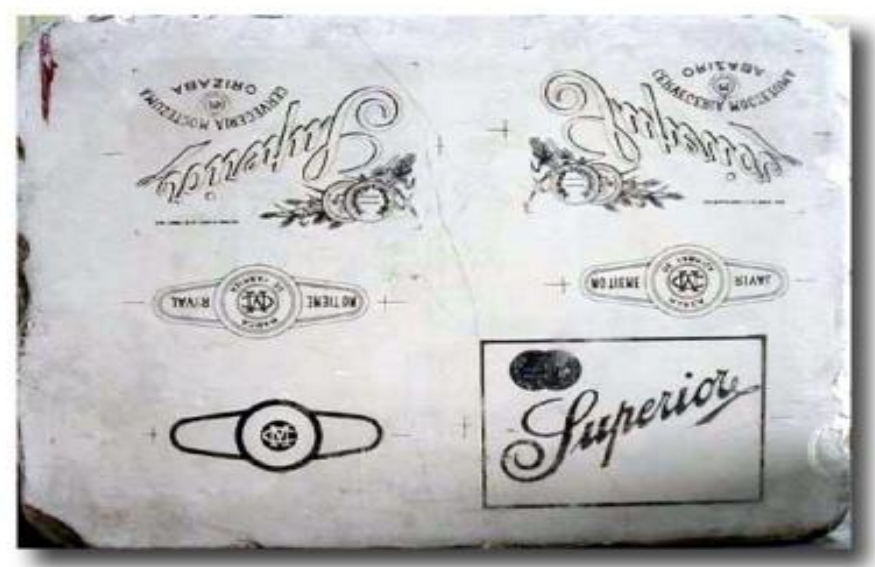

Figura 10 Piedra litográfica. "Cerveza Superior” Academia de San Carlos

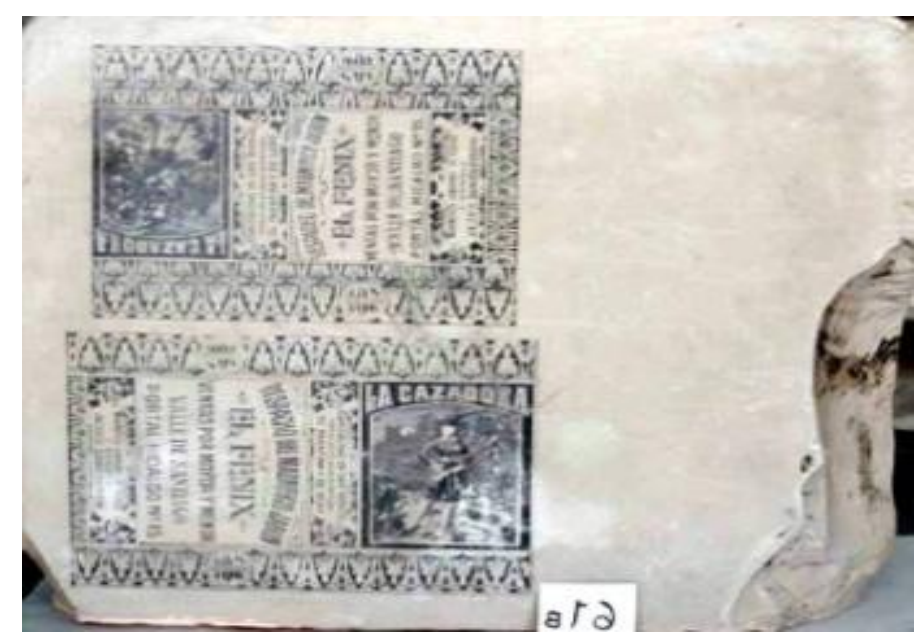

Figura 11 Piedra litográfica. "El Fénix” Academia de San Carlos 
Cuando entramos a la litoteca de la Academia de San Carlos y vemos las columnas de piedras, no podemos sino sorprendernos por la cantidad, sin embargo cuando lavamos cada una, la fotografiamos e imprimimos nos emociona ver la cantidad de imágenes y la calidad del dibujo y grabado.
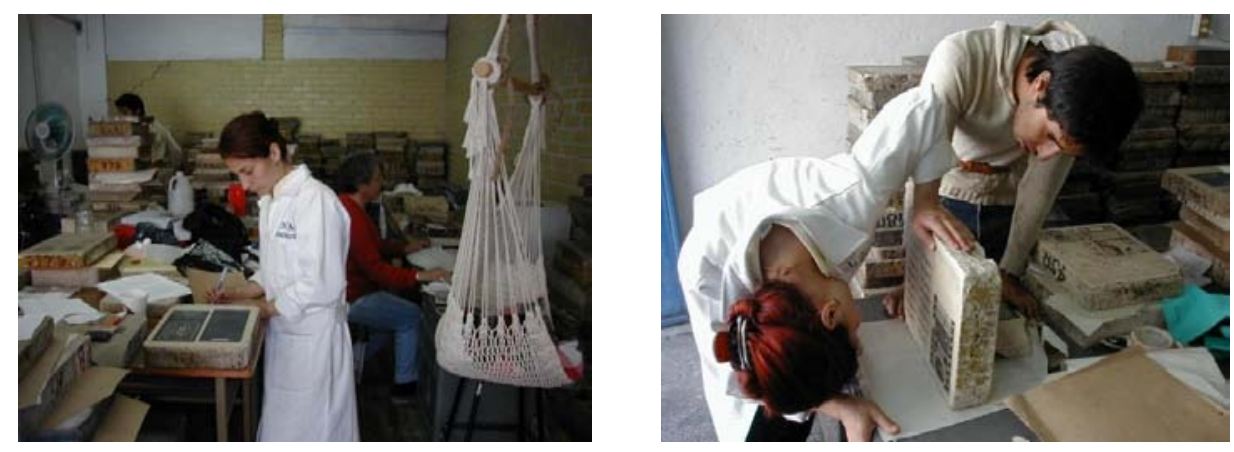

Figuras. 12 y 13Alumnos becarios del posgrado en Artes Visuales Taller litográfico Calle Academia 22.

Desde Septiembre del 2003 cuando inició el proyecto doctoral, hasta 2005 tratamos de recuperar las imágenes y con relación a las etiquetas de tabacos, puros y cigarros realicé la impresión de 32 etiquetas en papel algodón guarro y un video del proceso litográfico para la recuperación de las imágenes.
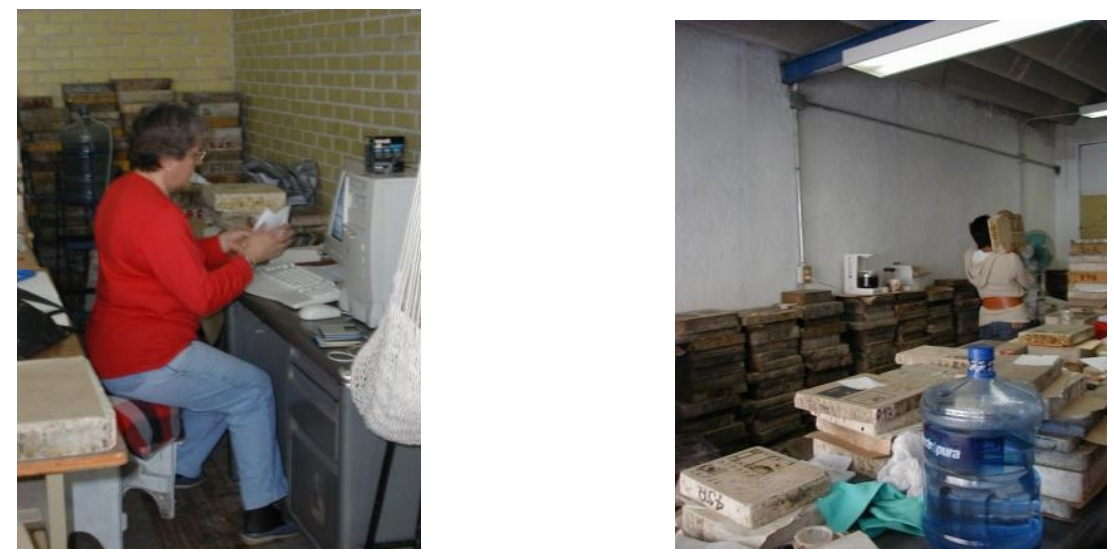

Figuras 14 y 15 Imágenes del taller de conservación de piedras litográficas 2002. Calle Academia No 22 (estacionamiento) 
Además de la ciudad de México otros estados contaban con compañías que se dedicaban a fabricar puros y cigarros pero la mayoría imprimían sus etiquetas en las litográficas de la Ciudad de México. Hemos seleccionado algunas imágenes de productos que se expendían en otros Estados de mi país que se conservan grabadas en las piedras litográficas

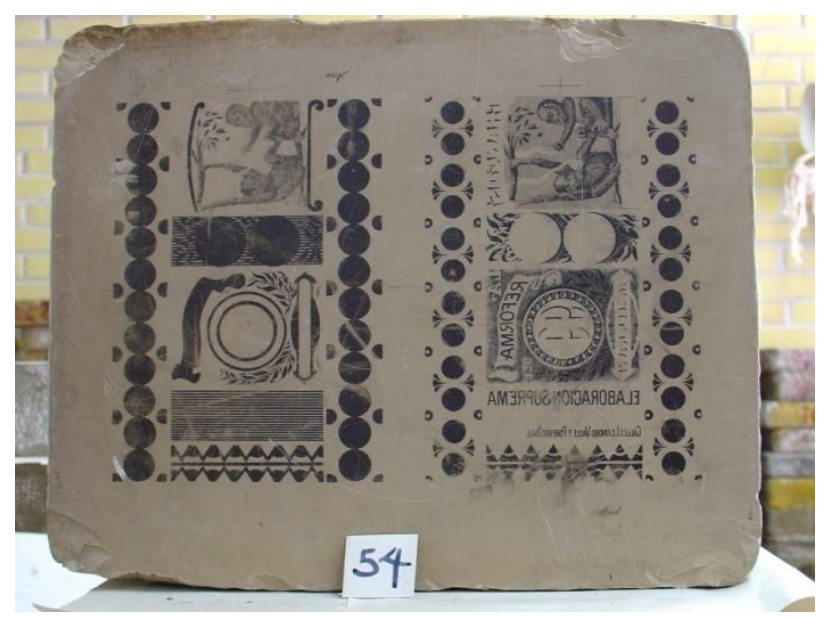

Figura 16 Piedra Litográfica. Academia de San Carlos. ENAP

Como comenté anteriormente realicé la impresión de algunas etiquetas para la tesis doctoral a partir de piedras litográficas de la Academia de San Carlos, en la imagen que sucede presentamos la separación de color de una etiqueta cromolitográfica, técnica inventada y patentada por Engelmann en 1837. El término define la impresión litográfica por sobreimpresión de varios colores con objeto de obtener imágenes polícromas. Requería tantas matrices como tintas a imprimir no había un límite pero las de mejor calidad plástica eran las que tenían más tonalidades. La realización de una litografía requería que el dibujante o el grabador litógrafo conociera los efectos de la superposición de colores para obtener mejores resultados de acuerdo con el orden de la impresión de las matrices, pero la gama 
cromática era creación del litógrafo; la correcta preparación del primer calco que se obtenía del boceto a color de la imagen original así se delimitaban las zonas correspondientes a cada color, una por cada color con sus cruces de registro que eran la guía para ajustar las tintas durante la impresión y por último el decalco exacto de las imágenes en la matriz o matrices de reportes y después su dibujo o grabado en función del tipo de matriz a emplear. ${ }^{11}$

Etiqueta de la Tabacalera Michoacana, S.A. en La Piedad Michoacán con un registro 239 que corresponde a "Triunfos" y otro Marca de Registro 24571 del 8 de mayo de 1925 tiene el nombre de la litográfica y tipográfica que realizaron la etiqueta: Graue. Además se observa que el registro es industrial, es decir para esta fecha ya no aplicaba el registro de propiedad artística en la Academia de San Carlos a pesar de ser una imagen litográfica.

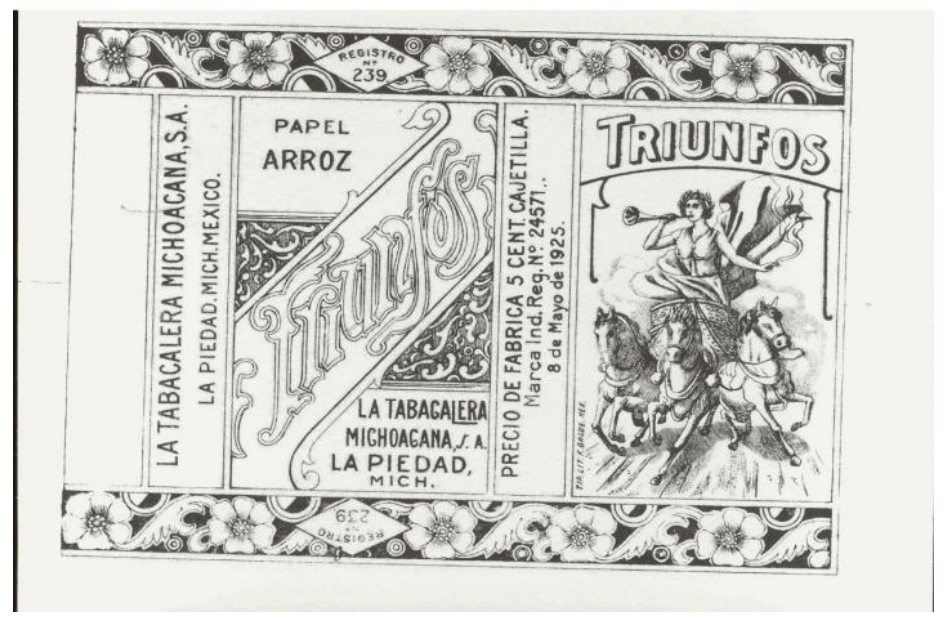

\footnotetext{
${ }^{11}$ Lidón Martínez Concepción. La litografía industrial en el norte de España de 1800 a 1950. Aspectos históricos, estéticos y técnicos. Guijón, Asturias, Trea, pp 250-253
} 


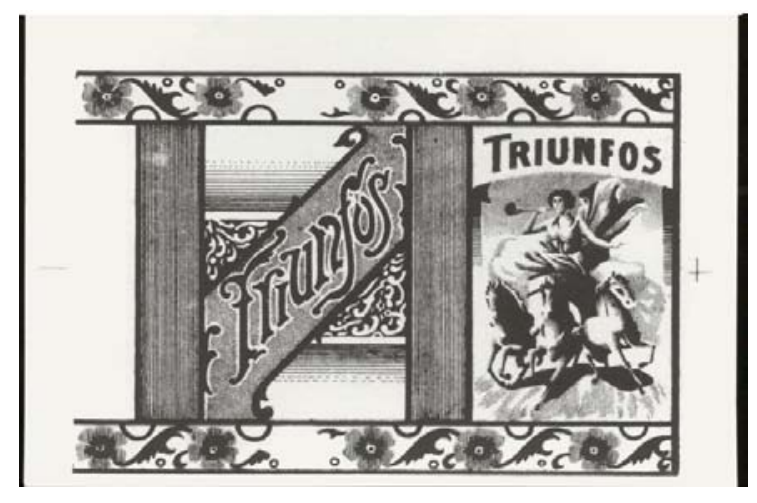

Figuras 17 y 18 Triunfos Tabacalera Michoacana. S.A. La Piedad Michoacán. Papel arroz. Precio de fábrica 5 centavos cajetilla. Marca Ind. Registrada 8 de mayo de 1925. Impr. L. Mayagoitia. Academia de San Carlos. 2003

En Culiacán Zazueta y C ${ }^{a}$ publicitaban la marca de cigarros "La Abundancia". Esta etiqueta proporciona muchos datos: nombre de la fábrica y almacén; el tipo de tabaco y sus presentaciones, los lugares de producción y el tipo de producto (puros o cigarros), forma de venta y la ubicación del local.

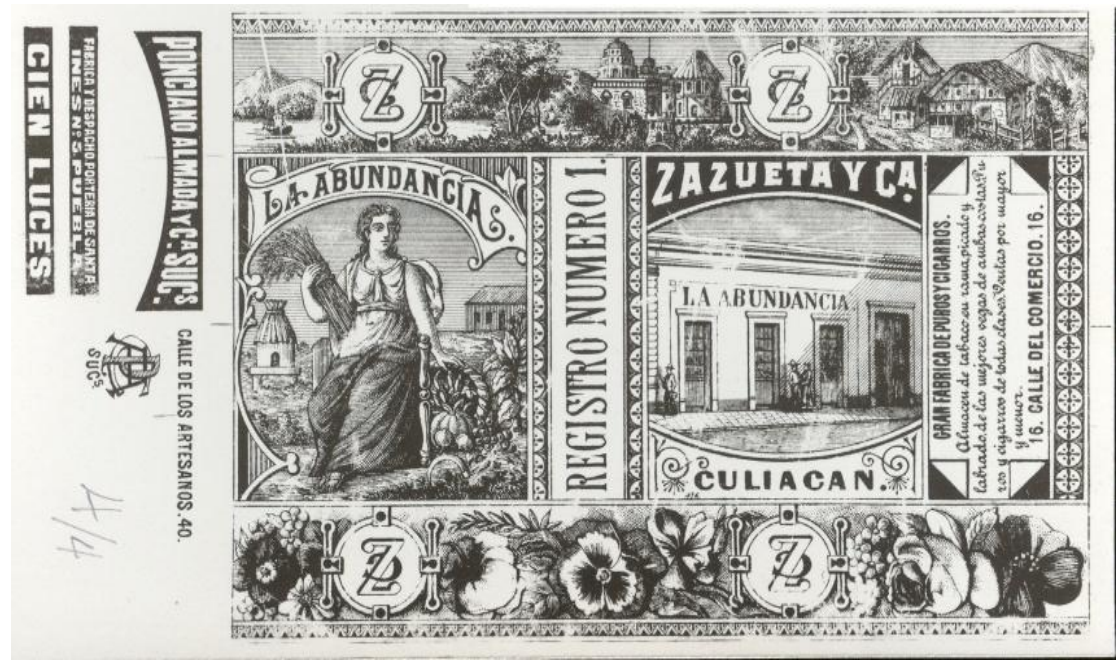

Figura 19 Ponciano Almada y Ca. Sucs. Zazueta y Ca. Culiacán, Registro No 1, Calle del Comercio no 10, Marca La Abundancia, Imp. L. Mayagoitia 2003. 


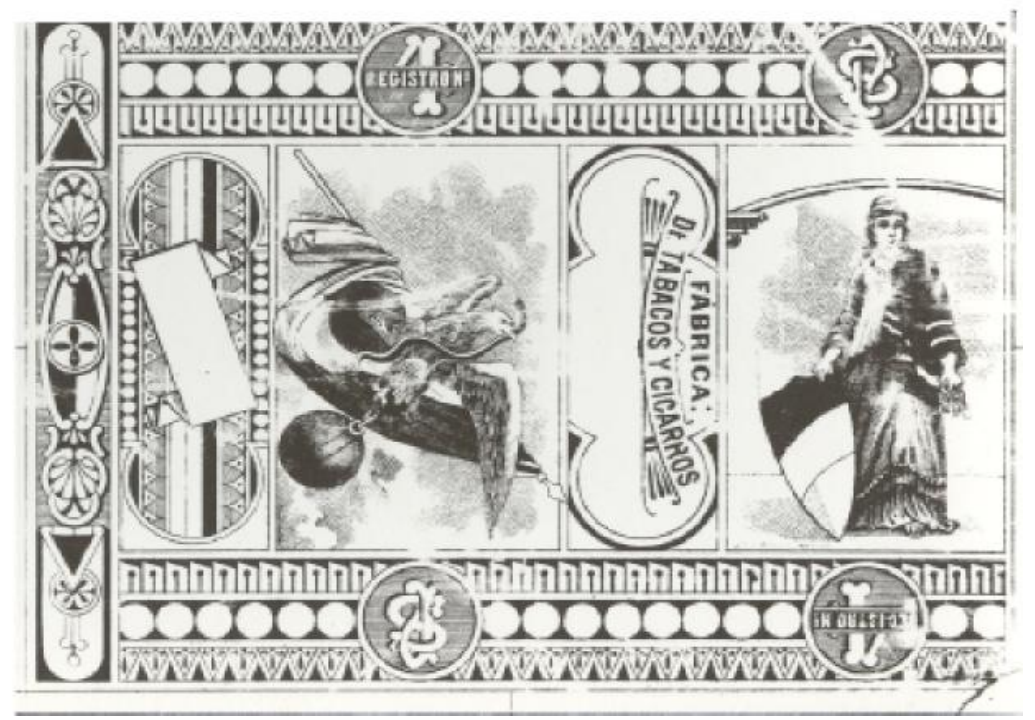

Figura 20 Fábrica de tabacos y cigarros. Selección de color. Imp. L. Mayagoitia 2003

\subsubsection{Etiquetas del Acervo Lino Picaseño.}

El segundo grupo de imágenes son etiquetas impresas con registro de propiedad artística ante el Ministro de Educación Pública y Bellas Artes, Sección de Instrucción Preparatoria y Profesional. La fecha de registro de propiedad artística abarca de 1879 hasta 1900. Las etiquetas se entregaban en la Academia de San Carlos procedía este trámite, abriéndose un expediente en el que se indicaba la cantidad de ejemplares de etiquetas que se recibían, el nombre del dueño de la propiedad artística, la marca del producto en este caso cigarros o puros el lugar de procedencia, la fecha y la firma de la persona que recibía las etiquetas en la Secretaría de Estado y de Justicia e Instrucción Pública.

La Escuela de San Carlos turnaba otro oficio al Secretario de Justicia e Instrucción Pública, en el que mencionaba haber recibido el 
material litográfico y haber realizado el trámite de propiedad artística, el nombre de la marca y del dueño de la propiedad artística. Estos registros permanecen en el acervo reservado de la Biblioteca de la Facultad de Arquitectura de la Universidad Nacional Autónoma de México “Lino Picaseño".
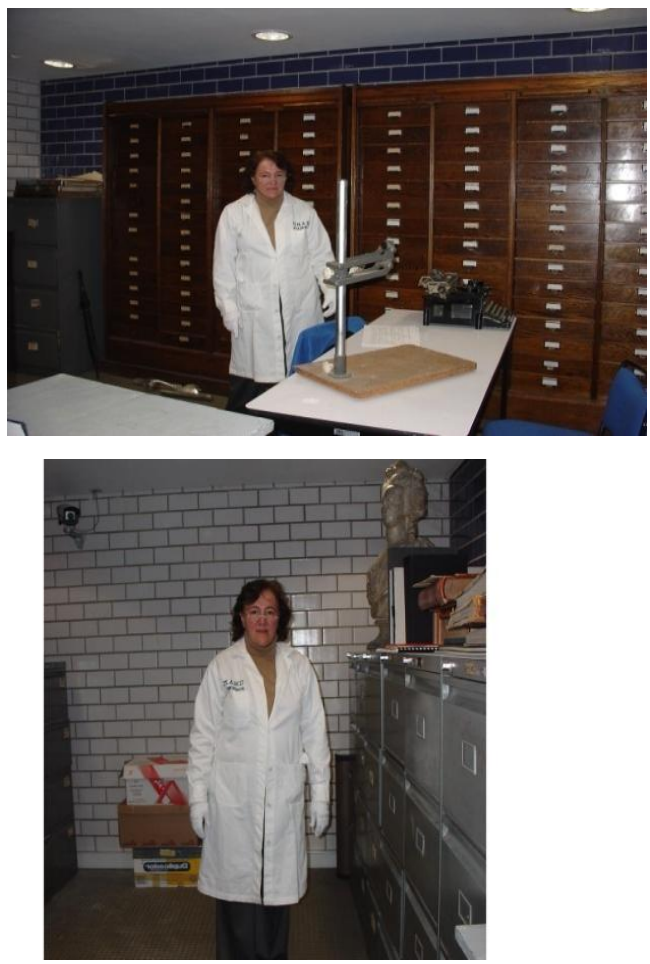

Figura 21 y 22 Laura Mayagoitia en el Acervo Lino Picaseño. Facultad de Arquitectura. UNAM. 2007. Fotografía. L. Mayagoitia

En los registros se asentaba en manuscrito el número de registro, se escribía el número del artículo del Código Civil a que se daba cumplimiento fecha y firma del responsable del registro. A continuación podemos observar un expediente: 

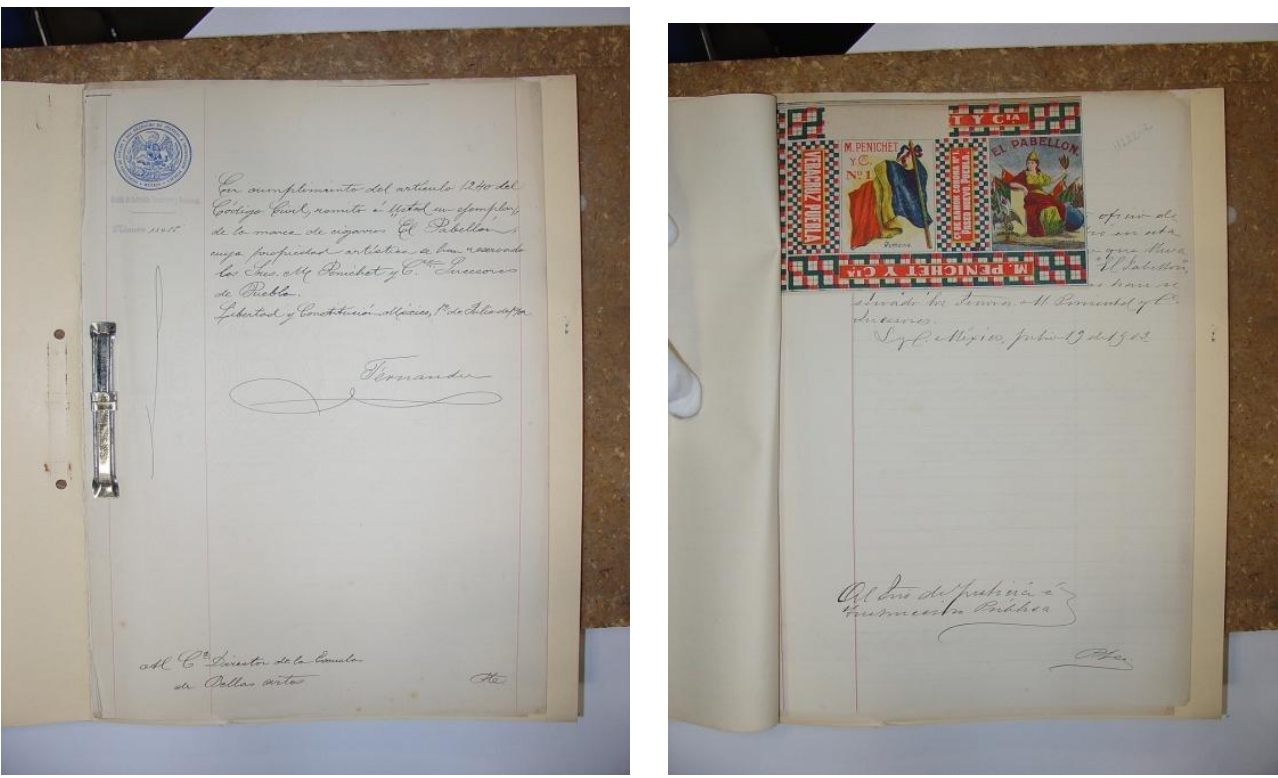

Figuras 23 y 24 Expediente de registro de propiedad artística. Penichet y Cía. 1 de Julio de 1902. Acervo Academia de San Carlos. Biblioteca Lino Picaseño. Etiqueta Marca "El Pabellón Mexicano"

Como parte del proceso de investigación realizamos un registro fotográfico de cada documento recibido por la Escuela de San Carlos el duplicado se enviaba a la Secretaría de Estado y de Justicia e Instrucción Pública, así como de cada una de las etiquetas litográficas ubicadas en cada uno de los expedientes consultados. Los datos de cada expediente son reportados en el sistema Maya que presentaremos en el capítulo 5, por tanto no consideré tan importante integrar en el mismo la fotografía de cada página de los expedientes, sin embargo estas fotografías se tomaron y están guardadas en Cd's. Nuestro trabajo abarca documentos emitidos del 5 de diciembre de 1879 hasta el 1 de julio de 1902, sacamos registro fotográfico de 271 etiquetas y sus respectivos expedientes, con registro de propiedad artística. La mayoría de las etiquetas tienen la firma de la casa litográfica o de la imprenta, y las de este periodo son 
de: Litográfica La Española, Victor Debray y Sucs., Emilio Moreau, Litográfica del Borrego y Litografía Catalana.

Antonio López y González ${ }^{12}$ fundó la fábrica denominada "La Rosa Aromática" fundada en 1885 en La Habana, Cuba en la calle Concepción Valla oㅜ 9, al paso de los años la fábrica pasó a manos de otros propietarios y algunas marcas son La ilusión, Reina Victoria, La Rosa Aromática, en México encontramos registro de propiedad autoral y algunas etiquetas

Algunas estampas eran impresas en otros países como Cuba o en algunas otras casas litográficas filiales de las españolas, francesas o inglesas, un ejemplo es la estampa de la litográfica The Guglier en $1910(30 \times 40 \mathrm{~cm})$ de la que se tomaron simplificadas las imágenes para las etiquetas de cigarros Centenarios que fueron litografiadas por una compañía extranjera The Goosefin

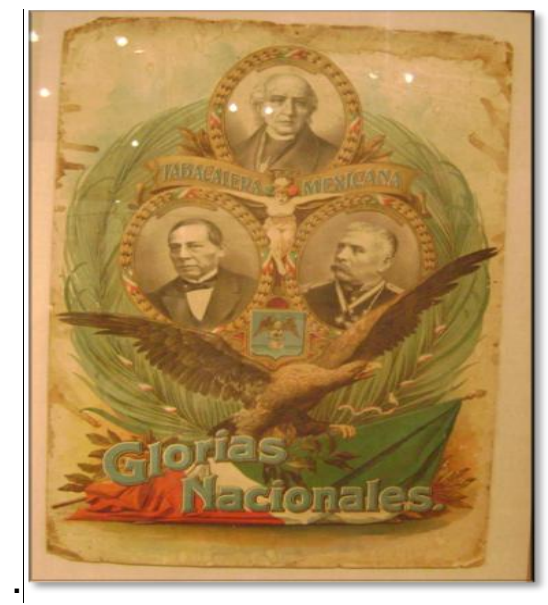

Figura 25 The Gugler Lito. Co. Cromolitografía. Museo del Estanquillo

Acervo Carlos Monsiváis. Glorias Nacionales

\footnotetext{
${ }^{12}$ Florencio Giménez Caballero y Manuel López Rodríguez. Cien Anillas de Calidad en la Litografía Tabacalera Sevilla, Giralda, 1998 p.348
} 


\section{管e}

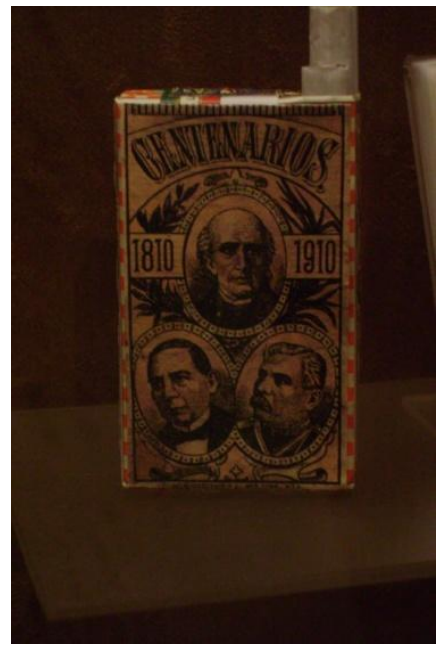

Figura 26 Cía. litográfica Gossefin Empaque para cigarros Centenarios, 1919.

Museo del Estanquillo. Acervo Carlos Monsiváis.

Presentamos como parte de este capítulo la impresión de las 271 etiquetas que fotografiamos en el acervo "Lino Picaseño". 
Etiquetas del Acervo Lino Picaseño. Pertenece a la Escuela Nacional de Artes Plásticas. En custodia en la Facultad de Arquitectura. UNAM
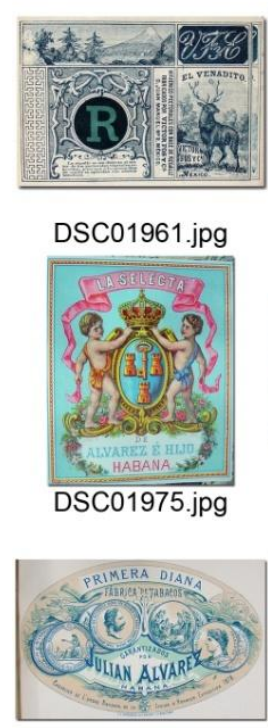

DSC01983.jpg

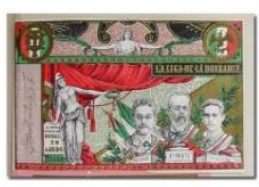

DSC02010_B.jpg
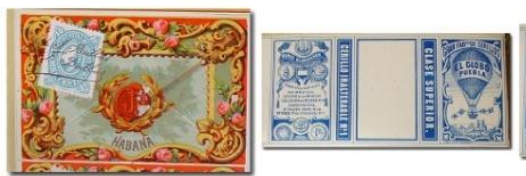

DSC02020_B.jpg

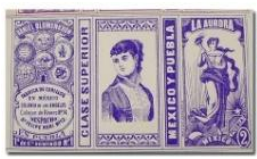

DSC02031_B.jpg
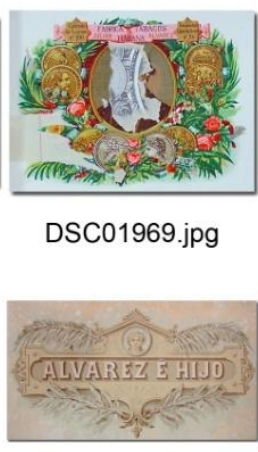

DSC01976.jpg

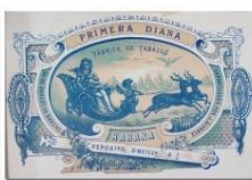

DSC01984.jpg

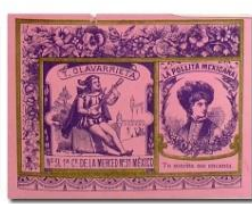

DSC02010_C.jpg

DSC02030_A.jpg

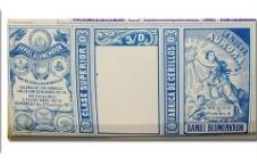

DSC02031_C.jpg

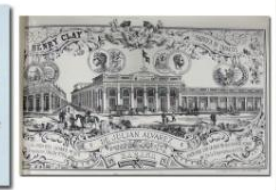

DSC01971.jpg
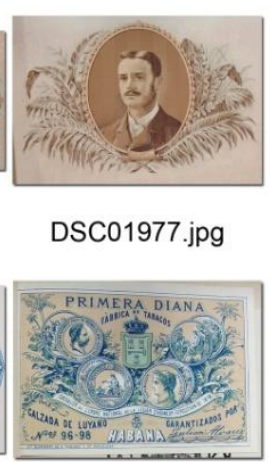

DSC01986.jpg

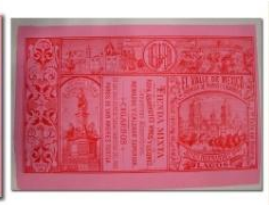

DSC02014.jpg

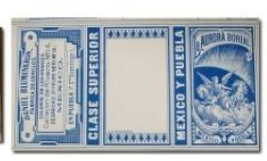

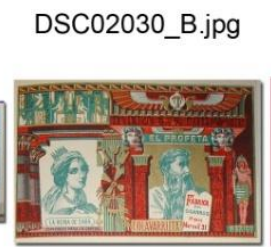

DSC02282.jpg
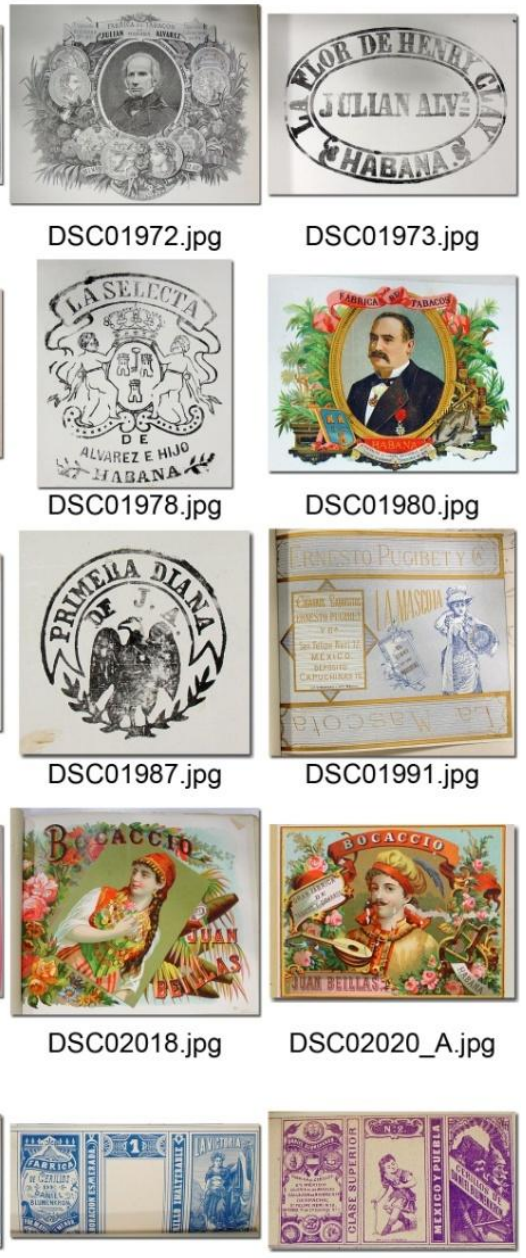

DSC01973.jpg
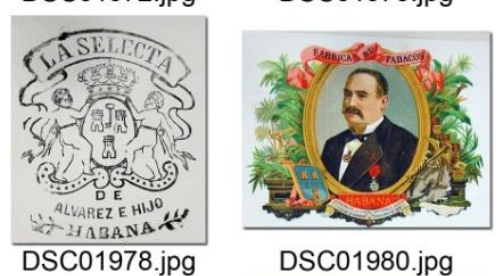

DSC01980.jpg
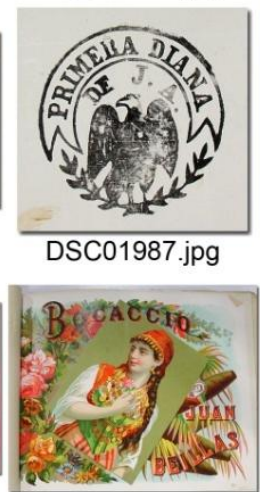

DSC02018.jpg
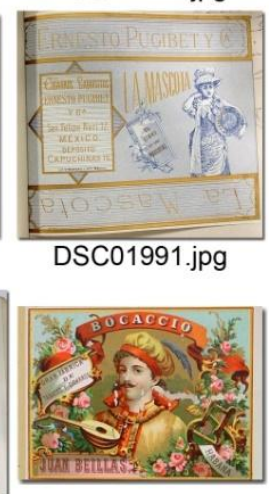

DSC02020_A.jpg

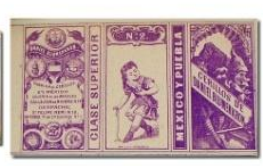

DSC02030_C.jpg

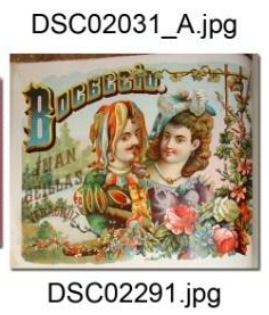




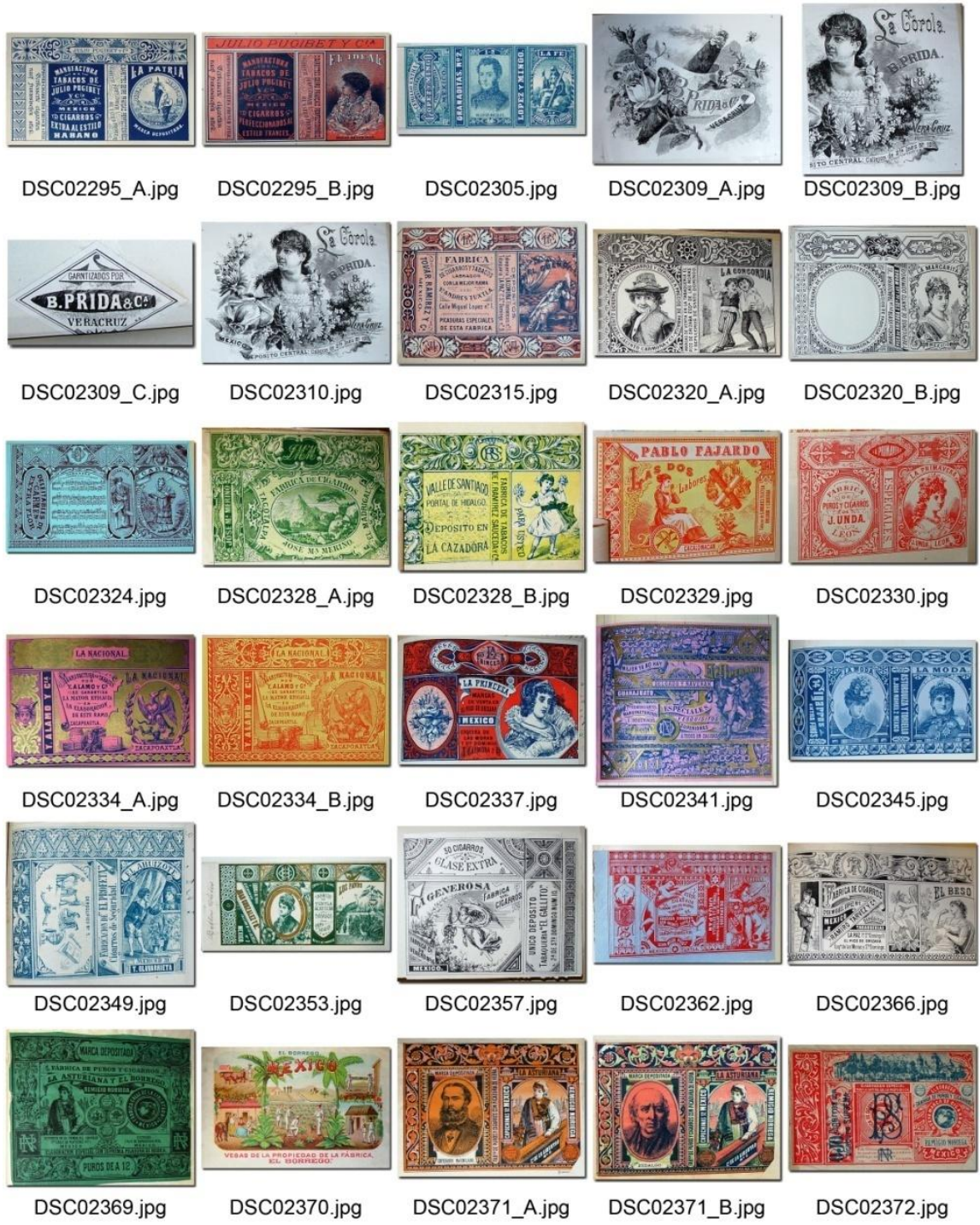



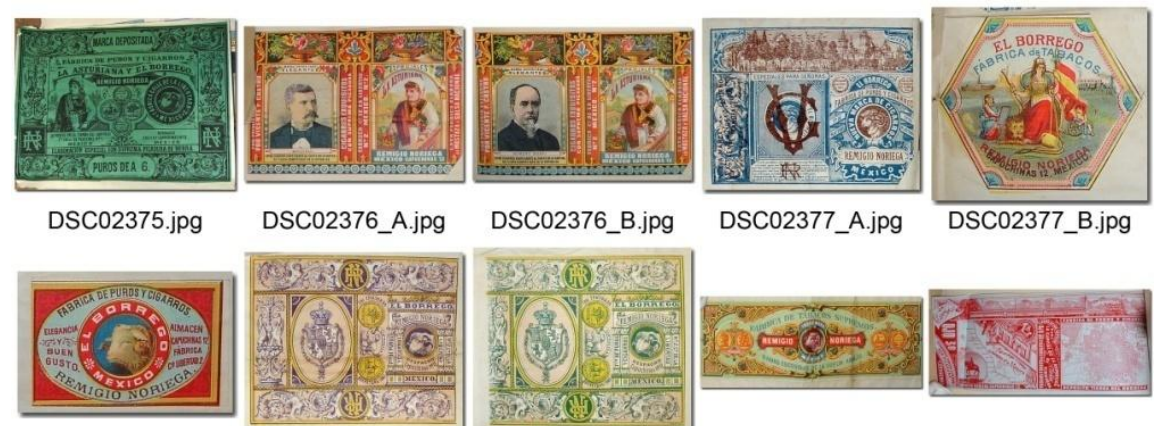

DSC02376_A.jpg

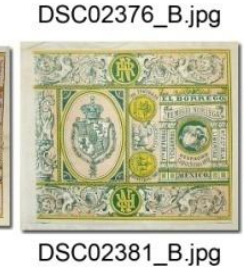

DSC02377_A.jpg
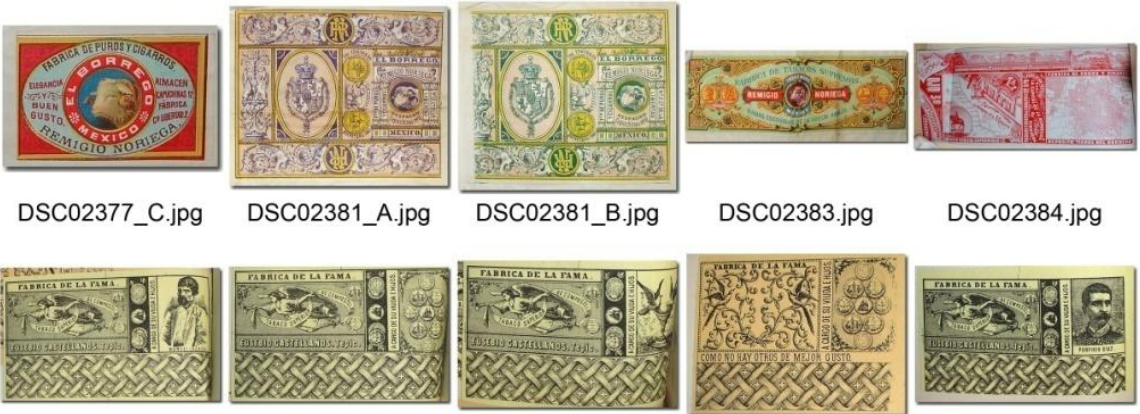

DSC02383.jpg

DSC02384.jpg
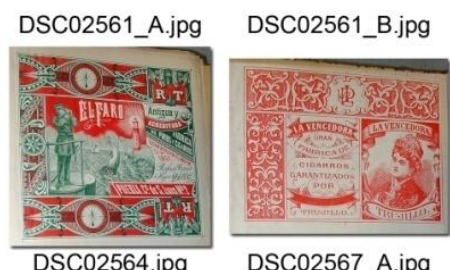

DSC02561_C.jpg
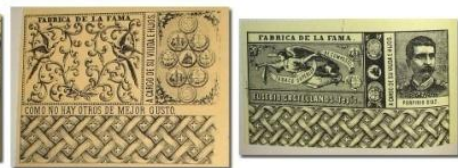

DSC02562_A.jpg
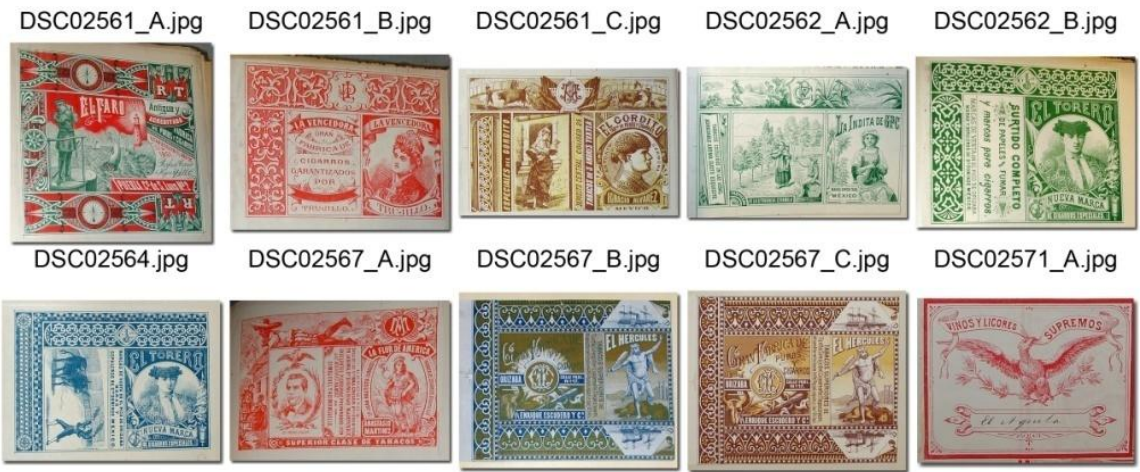

DSC02567_C.jpg

DSC02571_A.jpg

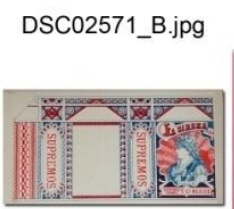

DSC02590.jpg
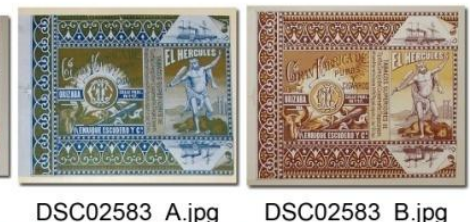

DSC02583_B.jpg

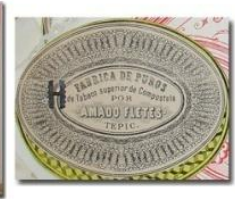

DSC02597.jpg

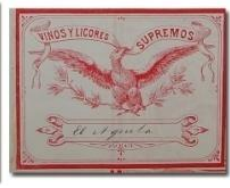

DSC02586.jpg

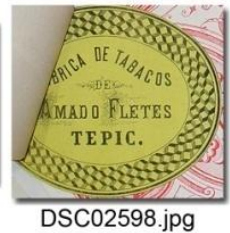



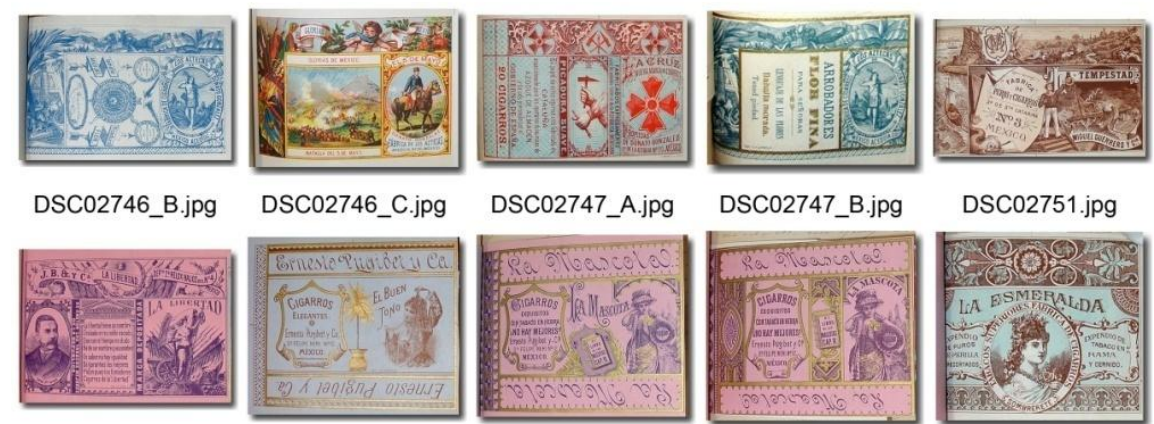

DSC02751.jpg
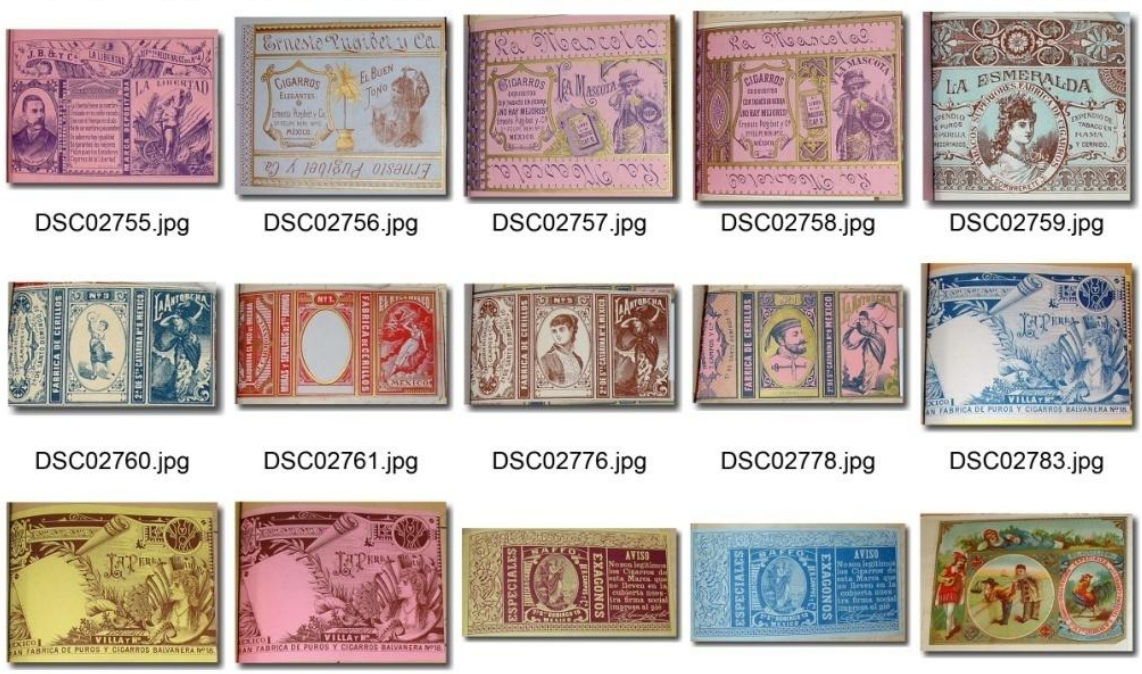

DSC02761.jpg

DSC02776.jpg

DSC02778.jpg

DSC02783.jpg
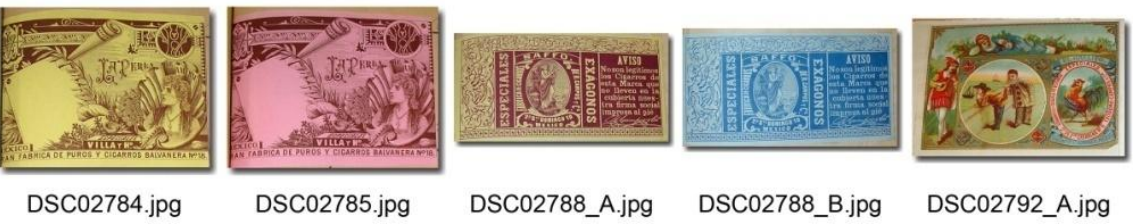

DSC02785.jpg

DSC02788_A.jpg

DSC02788_B.jpg
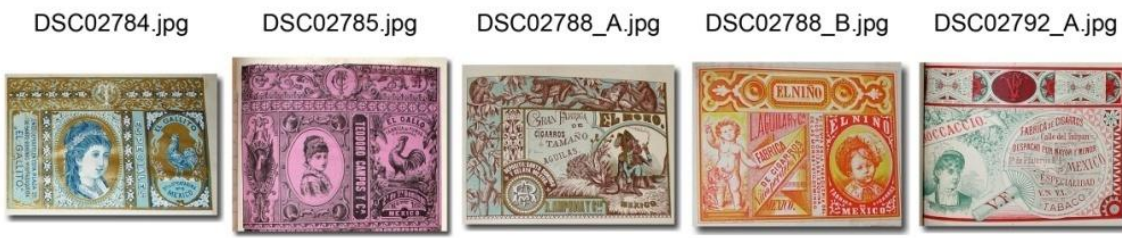

DSC02792_B.jpg

DSC02793.jpg
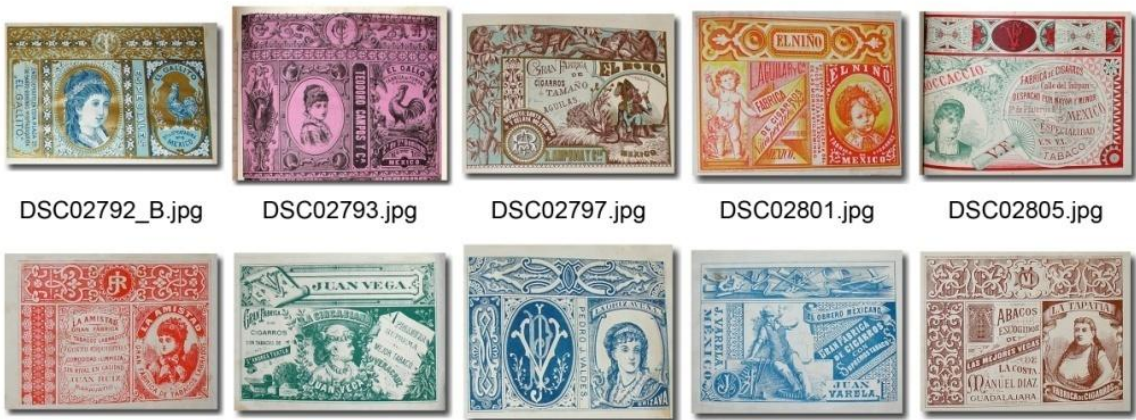

DSC02809.jpg

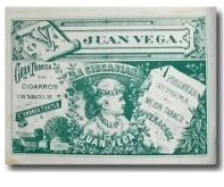

DSC02797.jpg

DSC02801.jpg

DSC02805.jpg

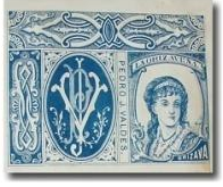

DSC02811.jpg

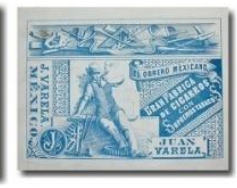

DSC02812.jpg

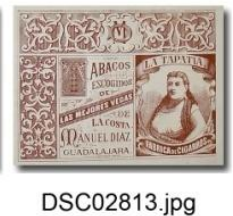




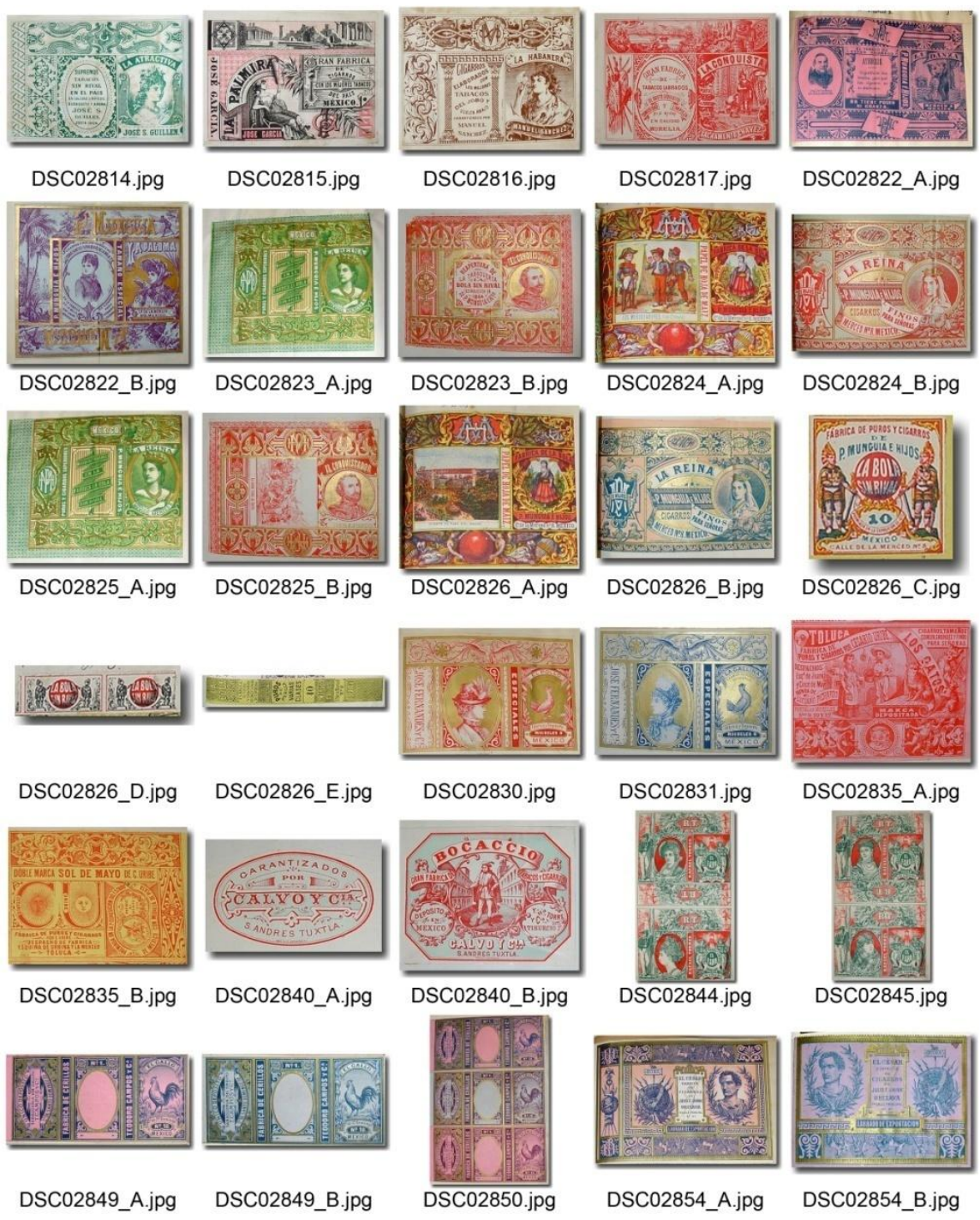



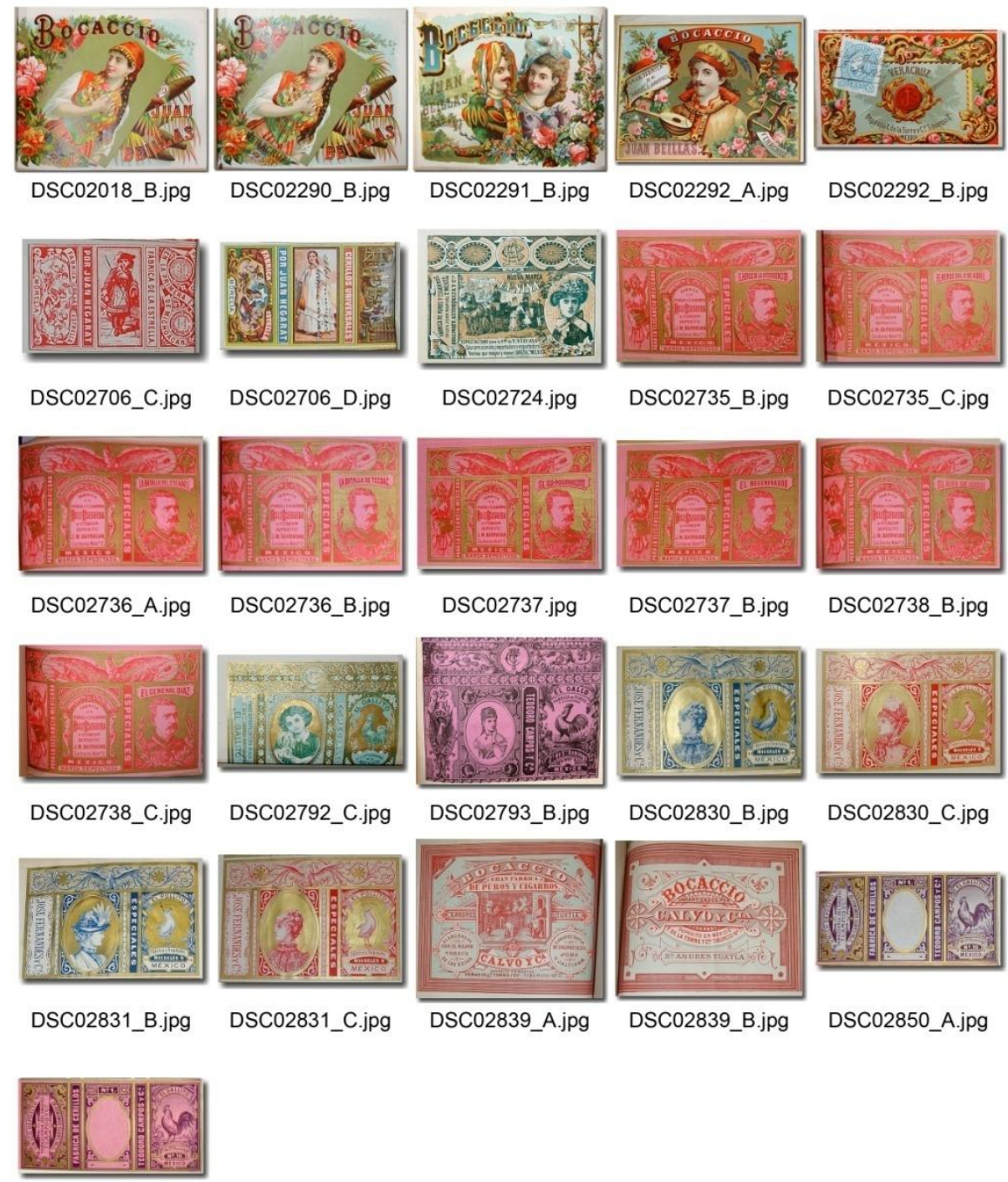

DSC02850_B.jpg 

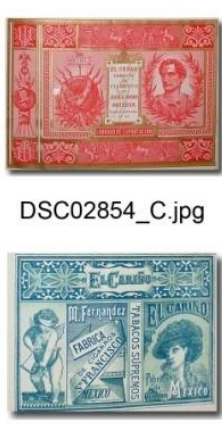

DSC02860_B.jpg

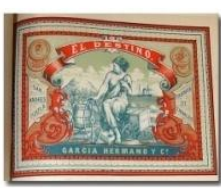

DSC02890_A.jpg

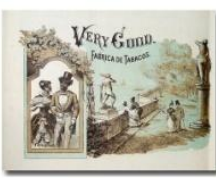

DSC02893.jpg
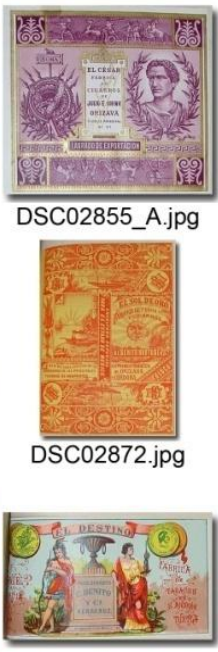

DSC02890_B.jpg

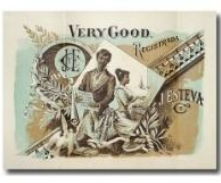

DSC02894.jpg

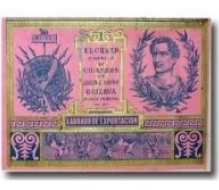

DSC02855_B.jpg

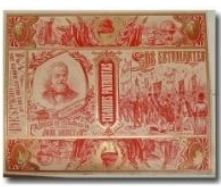

DSC02877.jpg

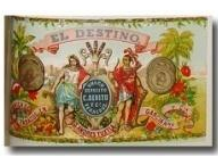

DSC02890_C.jpg

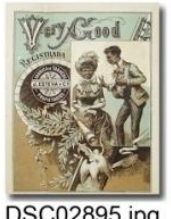

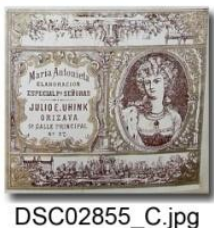

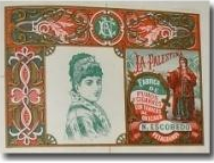

DSC02860_A.jpg

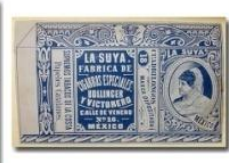

DSC02882.jpg

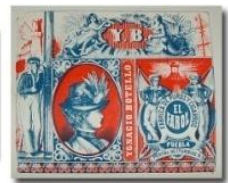

DSC02886.jpg

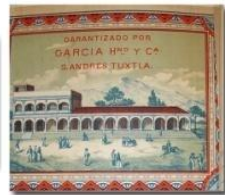

DSC02891_A.jpg

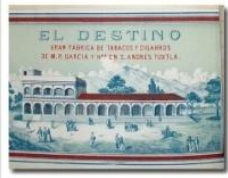

DSC02891_B.jpg

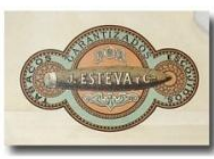

DSC02896.jpg

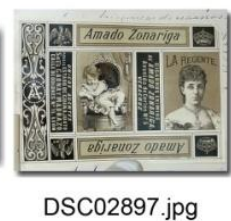


"Para el indígena simplemente era y se llamaba, pues su origen se perdía diluido en el tempo mitológico, a través del cual los dioses otorgan sus dones" ${ }^{13}$

\section{CAPITULO 2. DEL ORIGEN DEL TABACO, USOS, CONSUMO Y OTROS ASUNTOS.}

El tabaco ha sido sin lugar a dudas, uno de los productos que se venden más en el mundo, las etiquetas y su embalaje han sido modificados en el transcurso de los años. Durante la época prehispánica el tabaco se guardaba en toles (bules o calabazas) adornados con piedras preciosas y cintas, después era empacado en grupos de 20 cigarritos atados con hilo obtenido de hojas de plantas deshebradas, posteriormente fueron utilizando diversos papeles, cajas de cartón, de madera de cedro, hasta que se produjeron las cajetillas de cigarros con cartón delgado o cajas de puros bellamente adornadas y envueltas con papel celofán.

A través de la historia, en México durante el Siglo XIX se imprimieron etiquetas de cigarros y puros con la técnica cromolitográfica en talleres como: Debray, La Española, El Buen Tono, La Catalana, etc. Los diseños actuales por medio de líneas o imágenes sencillas, contienen características consideradas subliminales y acompañan a la publicidad en diversos medios. Tal como lo expresa Concepción Lidón ${ }^{14}$ refiriéndose al Litoral Cantábrico, en México durante la segunda mitad del siglo XIX el impreso publicitario y específicamente las etiquetas de tabacos y

\footnotetext{
${ }^{13}$ Manuel González Galván. El tabaco y las cigarreras mexicanas de oro y plata México, UNAM- IIE, 1980 p. 19

${ }^{14}$ Lidón Op. Cit. Pp176-180
} 
puros eran imágenes figurativas, en las que el texto transmite el mensaje y focaliza la atención del receptor, en tanto las imágenes de corte romántico, presentan figuras alegóricas que representan símbolos de progreso, piezas de arquitectura clásica, motivos vegetales, vistas, panorámicas, medallones, marcas, escudos, diseños de rótulos tipográficos, mensajes de tradición y regionalismo, paisajes regionalistas relativos a la actividad comercial por mar o tierra, acontecimientos históricos representados con las efigies de héroes, batallas, cuentos, epigramas, que representaban el más amplio nacionalismo, necesario para recobrar la identidad mexicana.

El capítulo que presentamos aborda la historia del consumo del tabaco y su representación en México prehispánico, colonial e independiente, para lo cual describiremos sus diversos usos y la publicitación de los productos derivados: cigarrillos y puros.

El uso del tabaco en México prehispánico formaba parte del mito, rito, magia y sacrificio. En Mesoamérica, cuando los grupos humanos se hicieron sedentarios desarrollaron una cosmovisión agrícola en la que el tabaco adquirió un carácter divino. Se le utilizaba en ceremonias religiosas tal como fue representado en los códices mexicanos. La calabaza en donde era colocado el tabaco aparece dibujada en el en el Códice Borgia y en el Nuttall, entre otros libros sagrados, como parte de los accesorios utilizados por los sacerdotes y también como símbolo de abundancia para pedir alimentos a algunos dioses como: Iztac Mixcoatl, el dios viejo del cielo; Ome Itzcuintli, el dios viejo de la vida; Tonacantecutli dios de la 
vida, dios anciano del Manuscrito de Viena; Izcoacahqui el dios el fuego ${ }^{15}$ en el Códice Vaticano 3773 , etc.

\subsection{EL CARÁCTER DIVINO DEL TABACO.}

En México, durante la época prehispánica, el tabaco era utilizado en ritos, ceremonias y en las prácticas curativas y si bien su historia se refleja en los códices no fue sino hasta después del descubrimiento de América, que algunos escritores españoles hicieron referencia al uso del tabaco y posteriormente de sus cualidades botánicas. A partir de entonces se presentaron grabados de la planta y de escenas en las que se mostraban las formas en las que los hombres indígenas la fumaban o esnifaban.

Según la interpretación de los códices y la historia de los pueblos prehispánicos, los aztecas, seguían ciertas tradiciones de los mayas y de otros pueblos de México alterándolas un poco. En el Códice Borgia por ejemplo, se representa la calabaza para tabaco yetecómatl como parte integrante del aderezo de los sacerdotes mexicanos. En los manuscritos, la calabaza de tabaco es el símbolo de abundancia de los víveres y pertenece al atavío de diversas deidades ${ }^{16}$.

Los indígenas ofrendaban a los dioses el tabaco considerándolo un alimento que les era digno, se colocaba dentro de un yetecómatl (fig. 29) que era un objeto lobulado de color amarillo, provisto de borlas en los lados y en la parte de abajo. Por encima de cuya abertura, de color oscuro sobresale una correa chalchihuitt, en la que

\footnotetext{
${ }^{15}$ Ibid. p 14

${ }^{16}$ Eduard Seler. Comentarios al Códice Borgia T-I México, FCE, 1963 p. 28
} 
los sacerdotes traían el yecualli, las bolitas de tabaco "la comida del tabaco" que utilizaban para provocar estados visionarios y extáticos ${ }^{17}$.

Los códices del Grupo Borgia son testimonio del arte extraordinario de Mesoamérica contienen representaciones de índole sagrada que presentan un orden y lógica propia y son muy expresivos, eran utilizados con fines religiosos como medio de comunicación entre el hombre y la divinidad a través de un sistema pictográfico ingenioso, preciso, armonioso y lleno de colorido. Los manuscritos pictográficos que integran este grupo son: El Códice Borgia, Códice Vaticano B, Códice Cospi, Códice Fejérváry Mayer y Códice Laud. En nuestra cultura prehispánica correspondió al dios Quetzalcoatl, Serpiente Emplumada, el portento de inventar la escritura y el calendario, en el tiempo cuando los dioses organizaron el mundo y crearon al hombre. Abordaremos la representación del tabaco en el Códice Borgia y en el Nuttall en los que aparece con mayor frecuencia.

El carácter sagrado de la escritura en los códices presenta una naturaleza mística y su importancia tiene un sentido mágico-ritual, que estrecha el vínculo entre los símbolos escritos y su influencia sobre lo real. Incorpora a los signos la esencia de los seres divinos en una manifestación festiva y debido a la fuerza que contenía la escritura, era asumida con respeto y veneración. El códice se dibujaba de forma artística y con una actitud mística, sobre papel amatl o tiras de piel de venado curtida, se colocaba entre pastas de piel de jaguar o madera. Los tlacuilos eran sacerdotes considerados sabios, es decir conocedores y guardianes de los secretos de la 
divinidad, conocían la escritura a través de la cual incursionaba al mundo sagrado de los dioses y la producían bajo un estado anímico y físico especial, no profano debían tener además de excelente memoria y destreza visual.

El códice Borgia ${ }^{18}$ o códice Yoalli Ehecatl fue escrito antes de la conquista de México, en algún lugar en el sur u oeste del estado mexicano de Puebla. Fue llevado a principios del la época colonial desde México probablemente a Italia y redescubierto en 1805 por Alexander von Humboldt entre las propiedades del cardenal Stefano Borgia. Actualmente el Códice Borgia permanece en la Biblioteca Apostólica del Vaticano. Este códice fue dibujado sobre piel de venado, consta de 39 hojas. Cada hoja es un cuadrado que mide 27 cm de lado tiene una longitud de casi 11 metros. Todas las páginas están ilustradas por ambos lados, 76 páginas en total y se lee de derecha a izquierda. Reproducimos algunas láminas e imágenes del códice en las que observamos la representación del tabaco.

\footnotetext{
${ }^{18}$ El Códice Borgia debe su nombre al cardenal italiano Stefano Borgia, que lo poseía antes de que fuera adquirido por la Biblioteca Vaticana. En 2004, Marten Jansen y Gabina Aurora Pérez Jiménez propusieron que se le rebautizara con el nombre indígena de códice Yoalli Ehecatl, náhuatl para "Noche y viento" aunque aún no es claro si sus creadores fueron nahuas. Obtenido de http://es.wikipedia.org/wiki/C\%C3\%B3dice_Borgia
} 


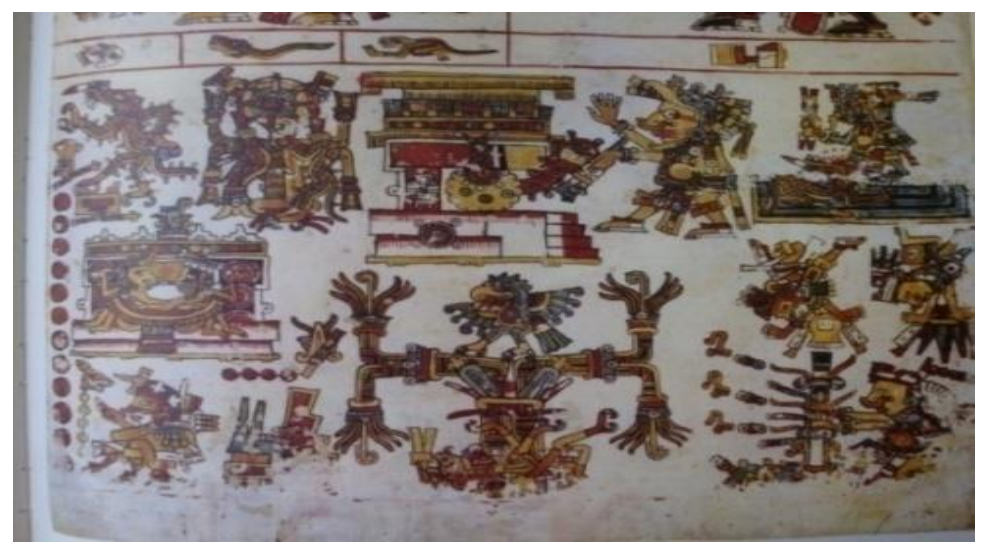

Figura 27 Códice Borgia, lámina 10, pintura 18 Las cinco regiones del mundo y sus deidades. Cintéotl Dios del maíz.

En el códice la tercera casa, Cihuatlampa representa el templo del oeste, tiene un Xochicalli (templo) provisto del friso de piedras preciosas con las siete flores en la base del tejado de paja, y tiene la forma característica de la casa de la serpiente roja, con su caballete ancho, doblado hacia abajo en sus extremos, solo en las jambas de la puerta de la cámara la decoración es distinta, parece representar un incensario o brasero de color blanco (Figs.27 y 28 ).

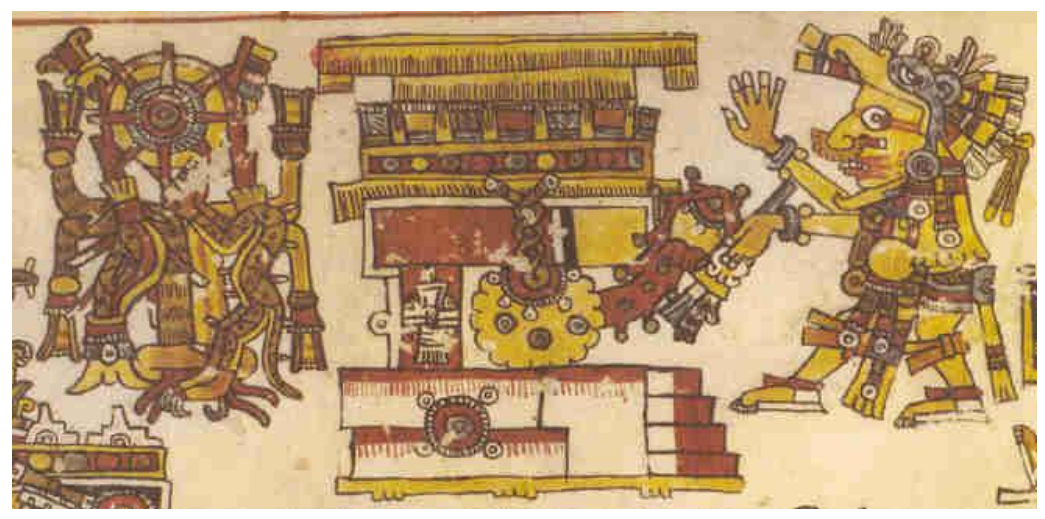

Figura 28 Casa del Oeste, Casa de los Mantenimientos (Detalle) 
El yetecómatl en el templo oeste, en la casa del maíz, representa una ofrenda a la diosa del maíz. ${ }^{19}$ La calabaza para tabaco (Fig. 26) es también un símbolo de Tonacatecuhtli, anciano dios y sacerdote, Señor de los Mantenimientos de esta forma la casa del Oeste queda caracterizada como una casa "de mantenimientos" 20.

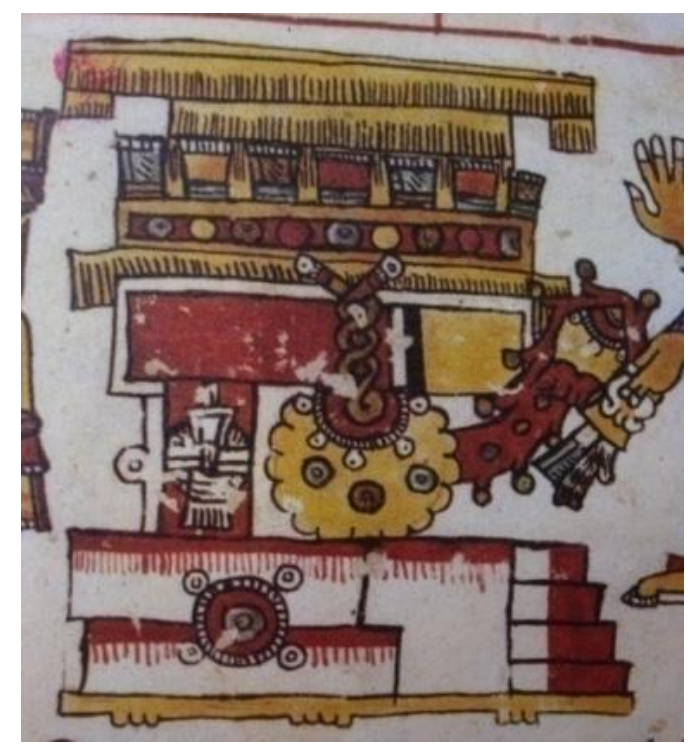

Figura 29 El yetecómatl Casa del Oeste, Casa de los Mantenimientos (Detalle)

A modo de fetiche o ídolo en la cámara vemos un yetecómatl (Fig. 29) como los que llevan a cuestas los sacerdotes, con incrustaciones de discos de piedras preciosas, el cierre y cintas de chalchihuitl entrelazadas se levantan verticalmente sobre la abertura: es exactamente igual al yetecómatl del dios anciano Iztac Mixcóatl en la el Códice Borgia o en los códices Vindobonensis y Nuttall. La calabaza en ocasiones contenía píldoras de tabaco molido y cal (yetecomatl o yeitecomatl) y era atributo del sacerdocio y objeto que

\footnotetext{
${ }^{19}$ Ibidem "Las cinco regiones del mundo y sus deidades" lamina 15 p. 51

${ }^{20}$ Eduard Seler. Comentarios al... T I y II.
} 
simbolizaba la fertilidad y abundancia. Se utilizó en prácticas mágicas, de tal suerte, que los hombres trataron de usarlo en su beneficio para tener acceso a la esfera sobrenatural y así liberarse de espíritus malignos, aplacarlos y obtener beneficios de dioses benefactores. ${ }^{21}$

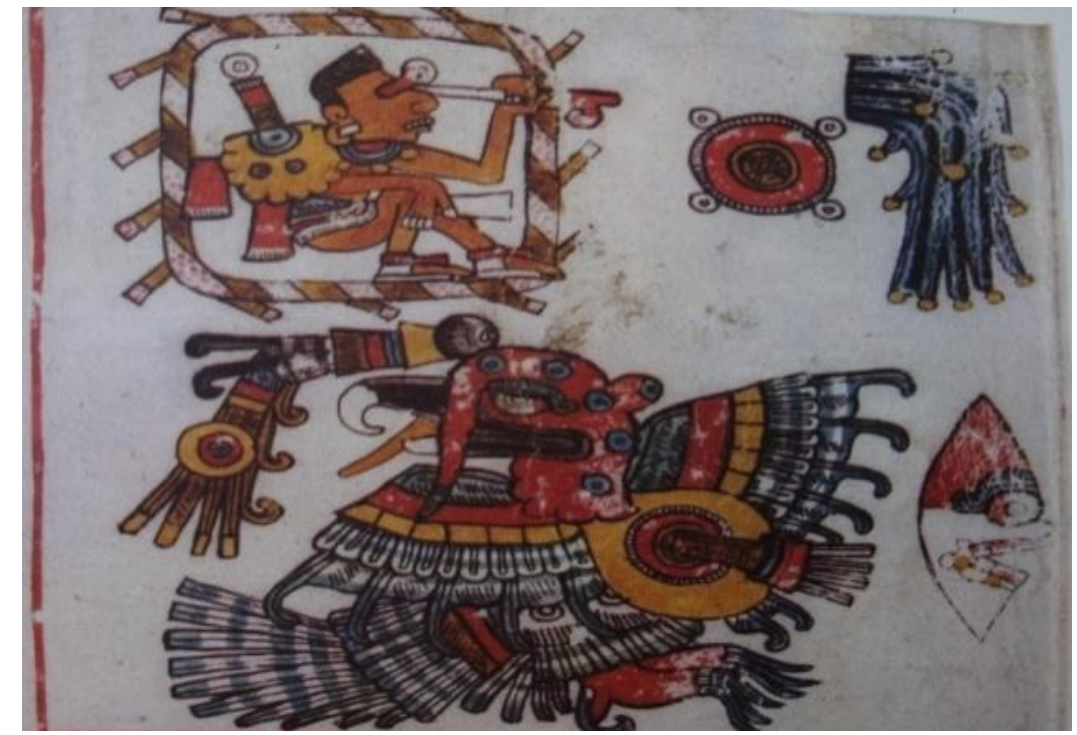

Figura 30 Día 18 Chalchihuitl. “Joya de agua”

Entre los mexicanos y sobre todo en los códices, en los que cualquier hecho está impregnado de alusiones al sacrificio, se da a Chalchihuiatl "Agua de piedra preciosa" "líquido precioso" el significado de la sangre que los penitentes se extraían en el auto sacrificio, de tal forma que el Chalchiuitotoli, "Gallina de piedra preciosa" o sea el pavo se convierte en el símbolo de Tezcaltlipoca, dios del castigo y símbolo de la penitencia. El Códice Borgia muestra en ese lugar los jeroglíficos chalchihuitl piedra preciosa verde, jade, esmeralda y "atl', agua, que juntos componen chalchihuiatl, "agua de

\footnotetext{
${ }^{21}$ Guillermo Céspedes del Castillo, El tabaco en Nueva España, Madrid, Discurso leído el día 10 de mayo de 1992 en el Acto de su Recepción Pública.
} 
piedra preciosa", "agua preciosa”, y el dibujo a su lado no deja dudas en cuanto al significado de esta agua que es la sangre ${ }^{22}$. Observamos en las figuras anteriores del Códice Borgia a Nezolistli, la muerte y Chalchih-atl agua preciosa, ambas tienen como atributo una calabaza de tabaco.

La descripción del día 18 corresponde a Chalchihuitl "Joya de agua" ${ }^{23}$ cuyo atributo es el yetecomatl. En el Códice Borgia, vemos sentado en medio de una especie de cercado (Fig. 30) trenzado por tiras de hierba malinalli o de juncos de color verde con puntos rojos, a un sacerdote que se está sacando el ojo con un hueso puntiagudo, es un punzón de hueso, "omitl'. Lleva a cuestas el yetecómatl, como atributo sacerdotal. Por el modo del trenzado en que sobresalen los cabos sueltos de las tiras, podemos identificar el cerco, como el dibujo que en los jeroglíficos de los reyes Nezahualcoyotl y Nezahualpilli muestra el elemento nezahualli, ayuno.

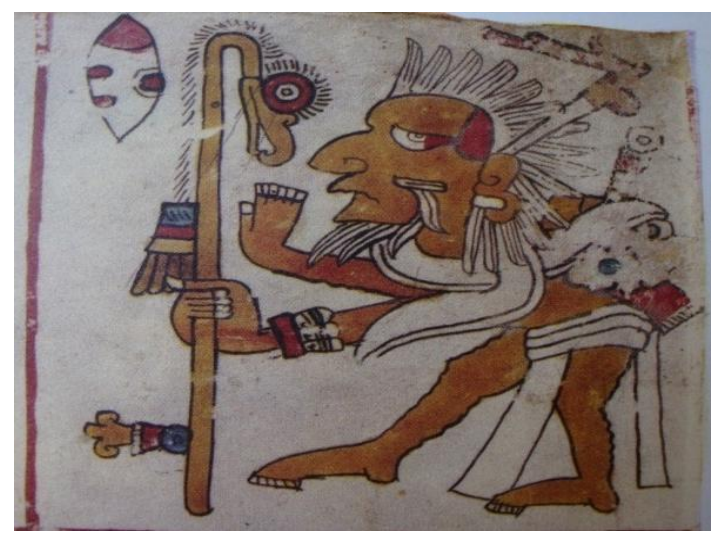

Figura 31 Iztac Mixcóatl Códice Borgia Lámina 24

\footnotetext{
${ }^{22}$ Códice Vaticano, lámina 93 figura 382 revela que el agua simbolizada por el pavo el chalchihuitotoli es sangre.

${ }^{23}$ Eduard Seler, Códice Vaticano 3773, La cuenta de los días y sus deidades figura 390 p. 184
} 
A Iztac Mixcóatp ${ }^{4}$ el viejo dios celeste, el anciano numen de la vida (Fig.31) lo caracterizan como dios anciano: los cabellos, la forma de la boca y la piel arrugada de las piernas y como sacerdote la mancha roja en la sien; asimismo por la calabaza para tabaco yetecómatl, que lleva a cuestas, además por el punzón de hueso cubierto de sangre, clavado junto a su oreja. Lleva como únicas prendas de vestir un taparrabo blanco y un paño blanco anudado alrededor de los hombros. Su orejera es una barra blanca. Le ciñe la muñeca una ajorca de caracol en forma de la especie llamada oliva que se encuentra fija sobre una correa. En la mano sostiene el báculo de la garza, aztatopilli. Aparentemente esta figura representa al Anciano Dios del Cielo o Dios Primordial. El cielo en cuanto morada de los sacrificados es quizá el concepto que une a esta deidad con el signo Tecpactl, pedernal ${ }^{25}$.

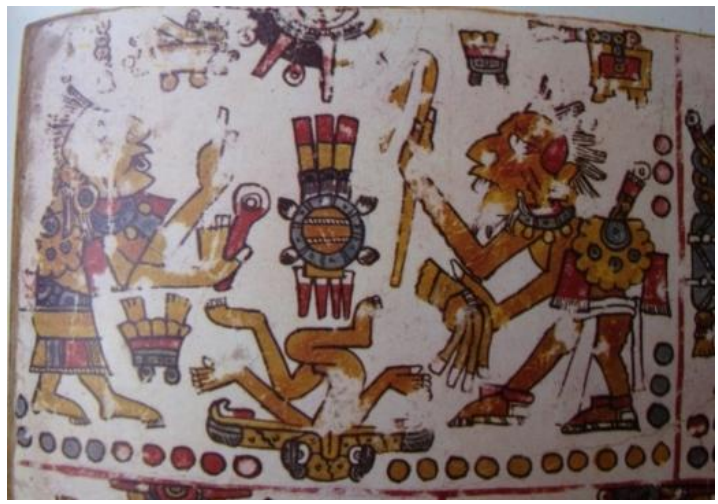

Figura 32 Las veinticinco parejas divinas. Ilancueye La vieja diosa de la tierra. Iztac Mixcoatl Viejo Dios del Cielo

\footnotetext{
24 Iztac Mixcóatl es el Ome Izcuintli, del Códice Vindobonensis es al mismo tiempo Tonacantecuhtli "Señor de la Vida" e Ixcozahuqui, la deidad del fuego es posible que el dibujo del Códice Borgia esté emparentado con uno se esos dioses. (Códice Borgia T-I p. 28). También se encuentra en la lámina 24, del Códice Feyhevary Mayer con Ixtac Ixcoatl, el anciano Dios celeste corresponde directamente, el dios anciano del bastón blanco de plumas de garza que aparece en el Códice Borgia junto al signo Tecpal- los dos: dios celeste el supremo y la serpiente de nube son los representantes genuinos de la fertilidad y la abundancia. (En: Eduard Seler Cometarios...Op. Cit. T-I p. 237).

${ }^{25}$ Eduard Seler Comentarios... Op. Cit. p. 232-233.
} 
En la figura 6 que corresponde a la lámina 60 del Códice Borgia, vemos a dos figuras ancestrales (Fig. 32): Xochiquetzal (Ilancueye) a la izquierda representa la tierra, tiene en la mano un tallo largo rematado con un ojo. En su labio superior lleva un apéndice anular. Observamos en su espalda un yetecómatl.

Motolinia y Mendieta mencionaba a Mixcóatl y a llancueye como habitantes de Chicomóztoc (lugar de siete cuevas) de quienes desciende el género humano. Son llamados también Tonacatecuhtli y Tonacacíhuatl o Huéheteotl e Ilamatecuhtli. La primera cautiva y sacrificada fue la anciana diosa lunar, diosa de la tierra y que por esta razón se convirtió en diosa de la guerra. El anciano dios a la derecha ${ }^{26}$ representa el cielo, tiene la cabellera y la barba con plumas blancas, un apéndice anular en el labio superior y tiene un yetecómatl en la espalda lo que lo caracteriza como un sacerdote, una mancha roja en la sien, en su mano porta un báculo con cabeza en forma de garza es el aztatopilli malinalli y en la otra malinalli, hierba.

Entre los dos dioses aparece un escudo y el haz de dardos que representan a la guerra, es importante recordar que aun cuando los dioses no son guerreros es precisamente la guerra la que aporta las víctimas del sacrificio. El Sol no podía nacer hasta que se le ofrecieran sangre y corazones para alimentarlo, elementos que le proporcionó la guerra. La dirección de "arriba - abajo" está representada por un hombre que se precipita de cabeza a las facuces terrestres abiertas (cipact/l), pero como los dos númenes

\footnotetext{
${ }^{26}$ Este sacerdote es igual al de la lámina 24 del Códice Borgia, es el 18 de los 20 númenes (lamina 55) y el en Códice Fejevary Mayer corresponde a la figura 143 y 144 en Los seis caminantes celestes.
} 
personifican tanto el cielo como a la tierra, la dirección hacia arriba y hacia abajo son la expresión perfecta del centro del mundo; son el tocle nahuaque es decir el señor de la vecinidad inmediata, el ilhuicahua: señor del cielo, tlaltipaque el señor de la superficie terrestre, el dios anciano, el dios del fuego. Al lado de los dioses hay vasijas que contienen sartas de piedras preciosas: cózcatl y plumas de quetzal: quetzalli lo que caracteriza a los númenes como dioses de la riqueza y abundancia y tal vez como señores de la procreación ${ }^{27}$

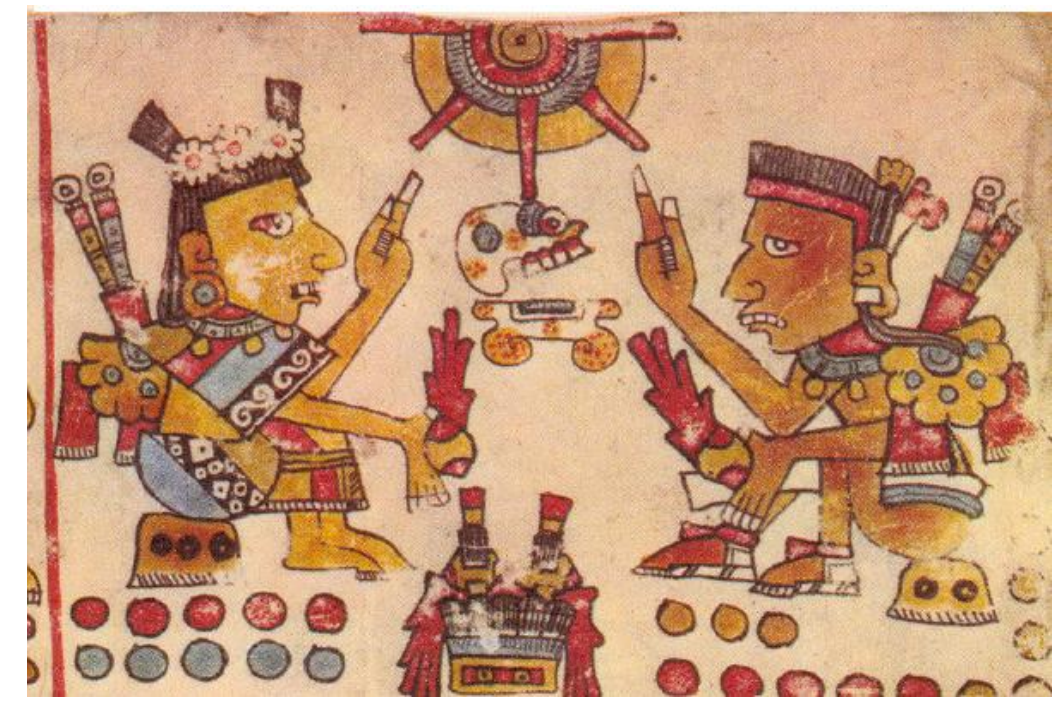

Figura 33 Día 12 de la región de abajo

El día $12^{\circ}$ de la región de abajo (Fig.33) es una imagen del Códice Borgia (pintura 492) y de acuerdo con los comentarios al códice, aparecen sentados dos sacerdotes que representan una de

27 Eduard Seler Comentarios...Op. Cit. TI p. 170 
las veinticinco parejas divinas: Tlamacazqui, y Xochiquetzal ambos portan una calabaza de tabaco en su espalda. ${ }^{28}$

La diosa con corona de flores blancas es Xochiquetzal. Ambos sostienen en la mano un corazón sangrante. A sus pies una vasija donde se colocaban los corazones. La vasija está ornamentada con plumas de águila en la parte superior y tiene dos cañas para absorber la sangre.

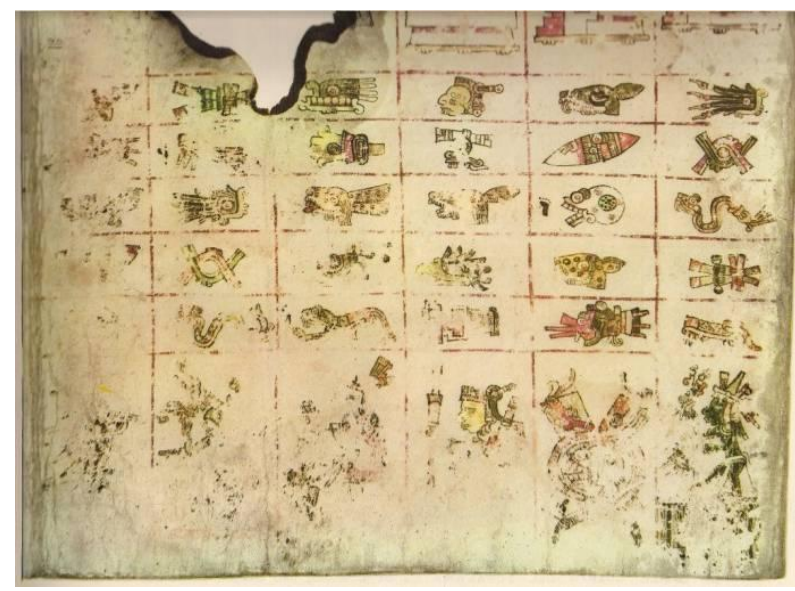

Figura 34 Tonalámatl Libro de los días

El Tonalámatl ${ }^{29}$ es el libro de los días y su influencia sobre los destinos (Fig.34). El número 20 fue el numeral de los mexicanos y de los habitantes de Mesoamérica debido a que es la suma de lo que el hombre puede contar con su cuerpo: los dedos de las manos y de los pies y utilizaba la combinación de los números 1 al 13 en hileras de 20 signos es decir 260 días.

\footnotetext{
${ }^{28}$ Códice Borgia, Op. Cit. lámina 22, p. 59.

${ }^{29}$ Eduard Seler. Comentarios...Op. Cit. T.I pp.11-13
} 
Pero los diferentes días no solamente tienen un ordinal, también tienen el nombre de objetos concretos, como animales: jaguar, caimán o cosas: casa, caña, viento, movimiento, pedernal, flor etc. En el primer cuarto del Tonalámatl en la columna 3 casa Ce cipactli "Uno Caimán" que también representa la Región del este, vemos un personaje (figs. 35 y 36) pintado con amarillo. Su cabello largo cae en la espalda y está adornado, a los lados de la coronilla, con un disco de piedra preciosa del cual sale hacia atrás una correa chalchihuitl, pintada con colores del jeroglífico. Lleva un báculo pintado de rojo y aparentemente la parte superior tiene una flor estilizada y en la espalda, una calabaza de tabaco que es el símbolo de la abundancia de los víveres, como hemos visto a lo largo de nuestro trabajo. Como mencionamos se trata de un objeto redondo, lobulado pintado de amarillo con una abertura en la parte superior y le sobresale una correa chalchihuitt.. El personaje representado es un caminante que tiene una mancha en la sien que denota a los sacerdotes debido a que éstos se untaban la sangre extraída de las heridas que causaban a sus víctimas. El personaje hace alusión al Dios del fuego Tlamacazqui que tlalsicco ónoc quien "vive en el ombligo de la tierra", es un sacerdote caminante que representa al numen de los mantenimientos. 


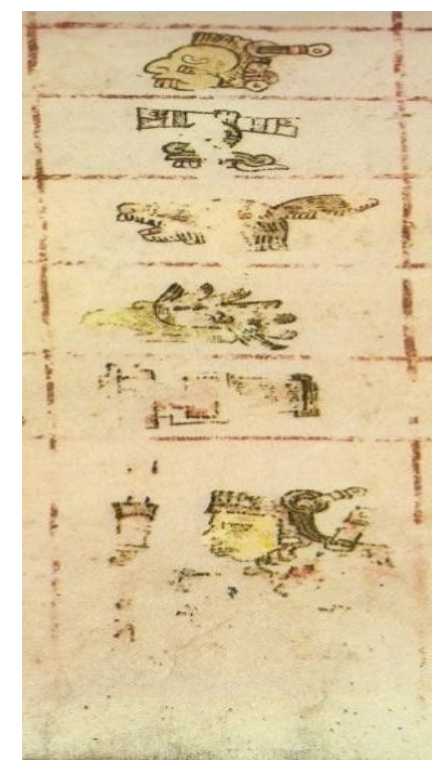

Figura. 35 Tonalámatl (detalle de la lámina 1, Codice Borgia)

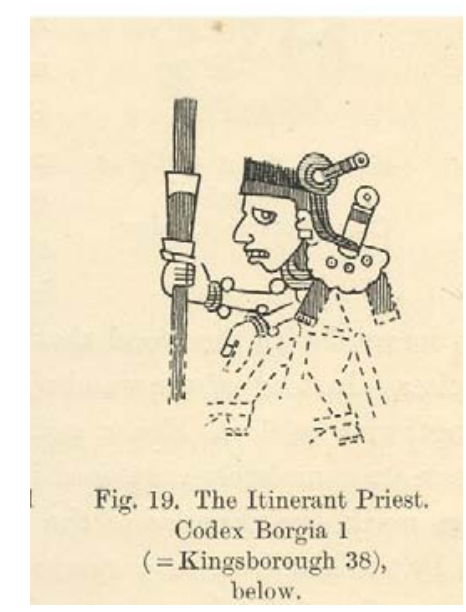

Figura 36 Tlamacazqui,

En otra pintura del códice (fig. 37) se observa al sacerdote Ome itzcuintli "2 Perro" con la calabaza para tabaco, yetecómatl a cuestas. El sacerdote lleva en su espalda un recipiente para la "comida" del tabaco llamada yacualli. ${ }^{30}$

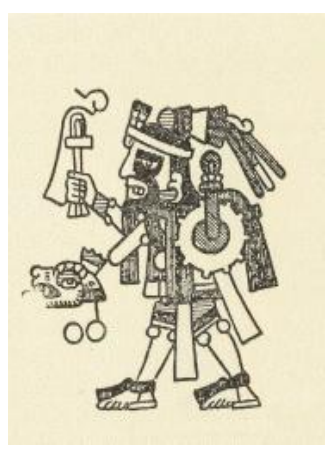

Figura. 37 Ome Izuintli Manuscrito de Vienna 10

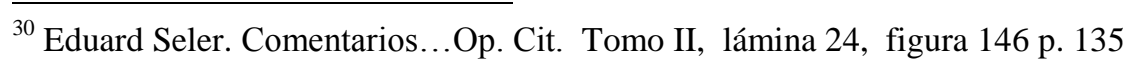



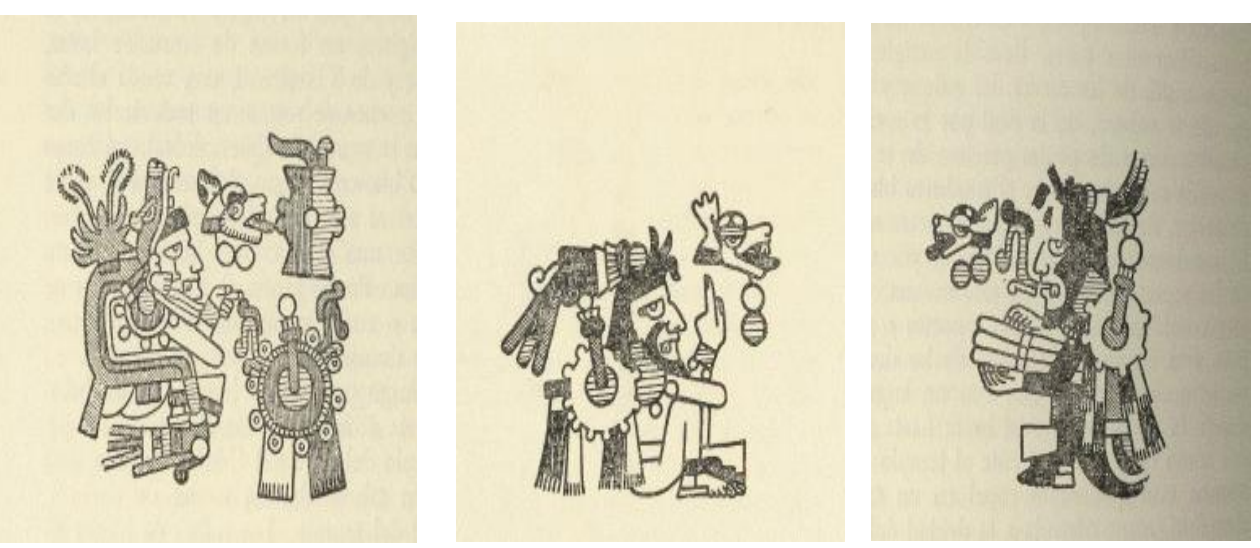

Figuras. 38,39 y 40 El Anciano Sacerdote Ome Itzcuintli, 2 Perro

\section{El sacerdote Ome itzcuintli "2 Perro" (Figs. 38,39 y40) también está representado en otros códices y lleva el yetecómatl a cuestas. ${ }^{31}$}

\section{Códice Nuttall o Zouche-Nuttall ${ }^{32}$ es de los pocos manuscritos pictóricos que sobrevivieron los embates del tiempo ${ }^{33}$. Provienen de}

\footnotetext{
${ }^{31}$ Ibíd. Lamina 24, figura 146 p. 135

${ }^{32}$ Códice Zouche Nutall. Ms 39671 British Museum, Londres.
}

${ }^{33}$ Es muy interesante el corpus que se refiere a la historia de La Mixteca Alta, donde los documentos más importantes son: Códice Vindobonensis Mexicanus 1 (Viena), cuyo anverso describe el origen de las dinastías mixtecas y en el reverso presenta la genealogía de los reyes de Tilantongo, lugar de donde probablemente proceden. Edición con comentario: Anders, Jansen, Pérez Jiménez (1 992a). Códice Colombino-Becker (México y Viena), que procede de La Mixteca de la Costa, al igual que el reverso del Códice Nuttal, contiene la biografía del Señor 8 Venado. Editado bajo el nombre de Códice Alfonso Caso, con comentarios del propio Caso (1966), y una introducción de Miguel León-Portilla (1996). Códice Bodley 2858 (Oxford), que contiene la historia genealógica de las familias reinantes de Tilantongo (anverso) y Achiutla-Tlaxiaco (reverso); es el documento clave para la cronología de la historia mixteca en general. Edición con comentario: Caso (1960). Códice Selden 3135 (Oxford), que trata de la historia dinástica de Jaltepec. Edición con comentario: Caso (1964); véase también Jansen, Pérez Jiménez (en preparación). Mapa de Teozacualco (Austin), que contiene un mapa redondo de la extensión del señorío de Teozacualco y una lista de los reyes y reinas de Teozacualco y Tilantongo. Véase Caso (1949), Anders, Jansen y Pérez Jiménez (1992b).Los primeros cuatro documentos fueron pintados en la época precolonial a mediados del siglo XV, probablemente poco antes de 1521. El Códice Selden 
la región mixteca y son notables por su magnífica factura, belleza y la importante información histórica representada en composiciones que asombran por su riqueza iconográfica. Es Códice Nuttall es rico en imágenes que representan al tabaco. El soporte del documento está conformado por 16 tiras de piel de venado unidas en cada uno de sus extremos de manera que forman una faja plegable de una extensión total de 11.41 metros. Las páginas de este códice son el resultado de los dobleces de esta faja de piel unida. Las dimensiones de cada página son aproximadamente 24.3 por $18.4 \mathrm{~cm}$. El número de láminas en ambos lados del códice es de 47, sin embargo, no todas fueron pintadas. En el reverso se narra la vida de 8 Venado y tiene pintadas solamente 44 hojas. El anverso que registra la historia y genealogía de varios pueblos tiene solamente 42 láminas con pinturas. Los colores aplicados en el Nuttall son: rojo, amarillo, azul, morado, café, ocre y negro. La superficie de la hoja es blanca debido a que se preparaba con una fina capa de estuco o yeso.

Se cree que dicho códice puedo haber sido hecho en el siglo XIV de nuestra era en el señorío de Teozoacoalco. Debido a que en el lado anverso se incluye una relación genealógica de los gobernantes de Teozoacoalco y Zaachila pone más énfasis en las conquistas, alianzas, reuniones políticas y actos de obediencia y reconocimiento a 8 Venado que otros códices. Además el lugar más representado en este lado es Tilantongo posible lugar de origen de la biografía del gran conquistador, aun cuando se ignora la fecha de 
entronización de 8 Venado en el señorío costero de Tututepec, entre otros acontecimientos.

Se desconoce la fecha exacta en la que pudo realizarse el lado 1 del códice, pero los hechos que registra pueden ubicarse entre los siglos XI y XII. Probablemente su factura respondió a una legitimación por parte de los descendientes de 8 Venado alrededor del siglo XIV, cuando la rama de Tilantongo comenzaba a desvanecerse.

El códice rinde cuenta de la genealogía, alianzas matrimoniales y hazañas militares del Señor Ocho Venado de Tilantongo y Tututepec, ciudades localizadas en el occidente del estado de Oaxaca. Narra el devenir de los pueblos y señores mixtecos en tiempos antiguos; una de esas historias, el trayecto al poder y el ulterior ocaso del Señor 8 Venado, constituye una de las más fascinantes epopeyas conocidas de la época prehispánica. En su anverso contiene la genealogía de la dinastía de Tezoacoalco, así como de otros señoríos, y el reverso narra la biografía del gran rey Señor 8 Venado. Varios años después, los señoríos de Tilantongo y Tezoacoalco fueron unificados por el señor 9 Casa, por lo que tal vez el códice cambió de residencia a Tezoacoalco, lugar donde se pintaría la segunda parte.

El códice es una pintura preciosa y de gran belleza artística. Es uno de los mejor acabados y más espectaculares que se conservan, sin menospreciar su calidad estética. Se observa que el contenido tiene un carácter diferente a su preciosismo, es importante para el estudio de los usos del tabaco en la época precolombina en México. Es recurrente encontrar en las láminas del Códice Nuttall personajes que tienen como atributos la calabaza y la bolsa de tabaco en la 
muñeca, el polvo del tabaco o el humo del tabaco. A continuación presentamos la representación del tabaco en este códice y algunos episodios que relata.

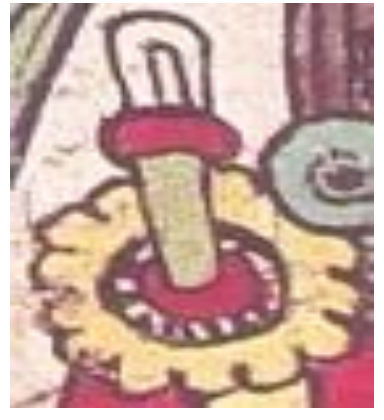

Figura 41 Representación del bule de tabaco

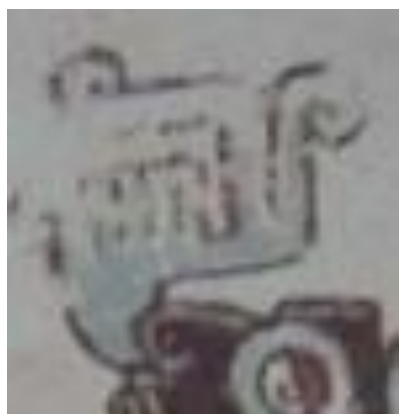

Figura 42 Representación del humo de tabaco

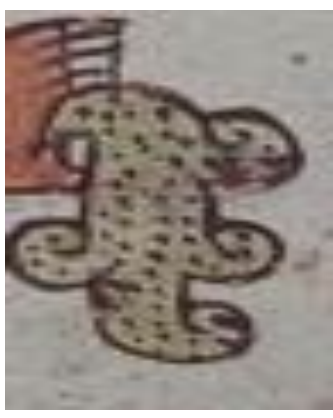

Figura 43 Representación del polvo de tabaco

El tabaco era utilizado en los nacimientos, matrimonios, entierros, aclamaciones a los reyes, sacrificios humanos. Se ofrecía en hojas, como canutos, sahumerios, etc. No solamente se fumaba o esnifaba, sino también se quemaba para ofrecer el aroma y humo a las deidades.

El códice Zouche-Nuttall principia con el nacimiento del Señor 8 Viento, quien según la interpretación del códice ${ }^{34}$ nació del Gran Árbol, Apoala se ubicaba entre dos ríos aledaños al asentamiento humano. Es un lugar identificado en la Sierra Norte de Puebla. En el Códice Vindobonensis se menciona un Valle de Tabaco Ardiente, Valle Sagrado donde estaba el Gran Árbol de Origen del que nacieron los fundadores de las dinastías mixtecas. Tanto el códice

\footnotetext{
${ }^{34}$ Crónica Mixteca El rey 8 venado, Garra de Jaguar, y la dinastía Teozacualco-Zachila libro explicativo del llamado Códice Zouche-Nuttall. Sociedad Estatal Quinto Centenario, Madrid y FCE, México, 1992.
} 
citado como el Nuttall, relatan que allí se realizaba la ceremonia del Fuego Nuevo. ${ }^{35}$

Además de indicar la historia dinástica, el códice nos da referencias de topografía, hidrografía y vegetación. De esta forma en cada una de sus páginas se ha dibujado parte de la historia de los habitantes de Teozacualco y Zaachila. En este trabajo abordaré lo relacionado con el tabaco porque en el libro que acompaña al códice se menciona que probablemente el tabaco representa una ofrenda, práctica considerada como algo sagrado.

La historia dinástica narrada es la del Señor 8 Viento, que surgió de la morada de los muertos, y fue recibido por varios personajes, entre los cuales estaban el Señor 12 Lagarto cargador del Sagrado Haz de Varitas que era el encargado del culto a los antepasados. Lo acompañaba El Señor 11 Flor que era el Cargador del Rollo de Mecate, un utensilio para medir los terrenos y al mismo tiempo símbolo de linaje. El Señor 10 Lagartija le ofreció fuego, el Señor 3 Águila sacrificó una codorniz y los señores 7 Mono y 7 Jaguar le ofrecieron vestimentas ceremoniales. Otros personajes le rindieron homenaje: 8 Zopilote sacrificó una codorniz, el Señor 1 Caña le ofreció leña para el fuego y el Señor 1 Lluvia vestimentas ceremoniales. Estos personajes lo acompañan como señal de su real dignidad y autoridad.

El nacimiento de los hijos de los reyes era todo un acontecimiento y las tribus prehispánicas tenían sus propios ritos, como lo veremos a través del estudio del uso del tabaco. Cuando nacían los niños eran recibidos por personajes importantes. El Señor 8 Águila ${ }^{36}$ nació entre

\footnotetext{
${ }^{35}$ Ibid. p. 95 Cita 21

${ }^{36}$ Códice Nuttall p.2
} 
magueyes y los cerros del Pájaro Azul, del Águila y de la Piedra. Lo acompañaron durante su nacimiento dos señores: 7 Viento, Hombre Verde quien esparció polvo de tabaco (Fig.44) esta acción era una ofrenda a la tierra y un acercamiento por medio del humo a la divinidad 10 Jaguar era el cargador del bule de tabaco. Su atributo es la calabaza de tabaco (Fig. 45).

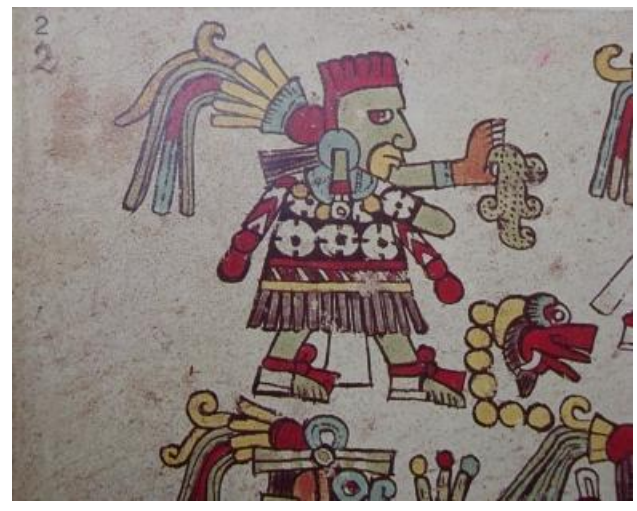

Figura 44 Lamina 2, pintura 8 del Códice Nutall El Señor 7 Viento, el Hombre verde que esparció tabaco.

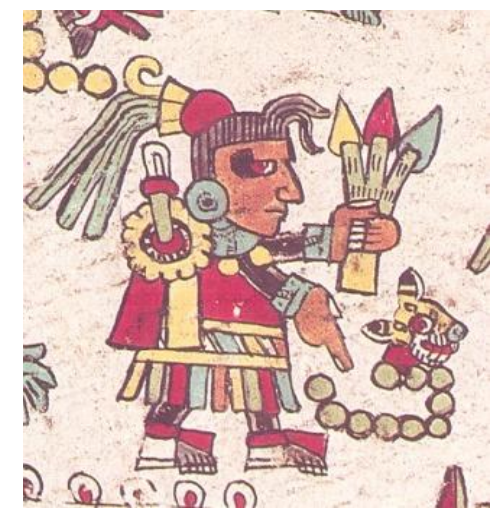

Figura 45 Lamina 2, pintura 9 del Códice Nutall El Señor 10 Jaguar Cargador del Bule de tabaco.

En las ceremonias guerreras también tenía un lugar importante el tabaco. Encontramos como ejemplo al luchar contra los Hombres Rayados $^{37}$ el Señor 4 Serpiente apresó a algunos, e hizo un sacrificio en la cumbre del cerro, le sacó el corazón al Señor Águila 1 Jaguar. En la misma página se dibuja el casamiento del Señor 10 Muerte con la Señora 8 Mono; siendo el Señor 2 Perro, el cargador del precioso bule de tabaco (Fig. 46) quien hizo ofrendas y puso un rosetón ante el Dios de la Lluvia, Patrono de la Mixteca

\footnotetext{
${ }^{37}$ Códice Nuttall p.4
} 


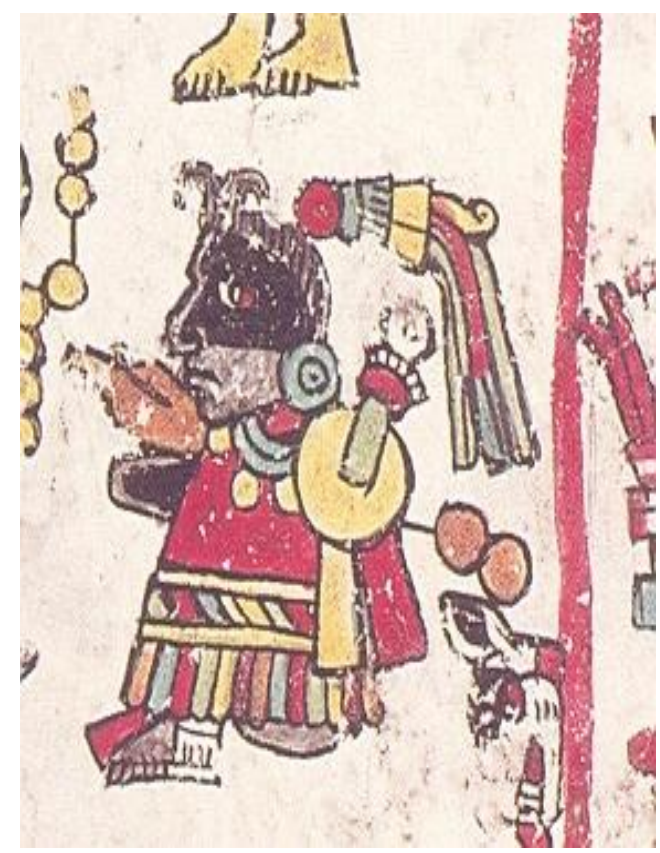

Figura 46 Lámina 4 pintura 19 El cargador del precioso bule de tabaco El Señor 2 Perro.

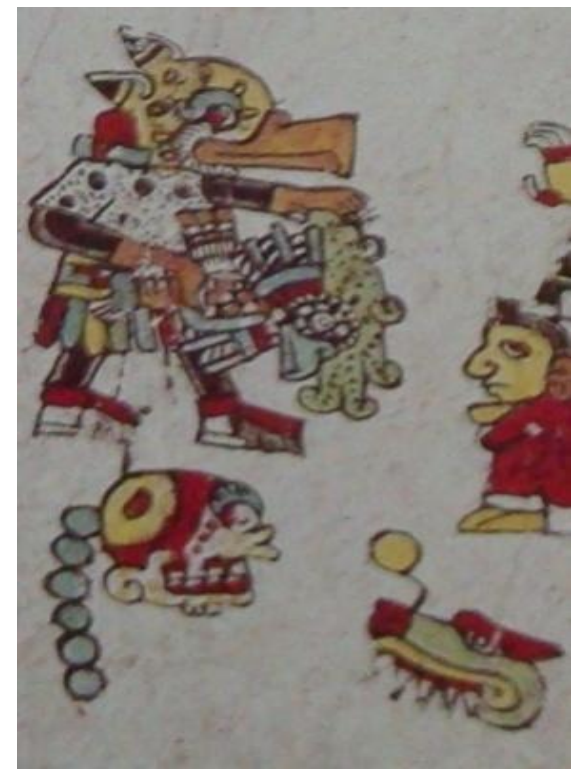

Figura 47 El señor 6 Muerte, Pájaro Jaguar ofrece una codorniz y polvo de tabaco.

En la ceremonia en que fue aclamado como soberano el Señor 8 Viento, el Señor 6 Muerte Pájaro Jaguar le ofreció una codorniz y 
polvo de tabaco. (Fig. 47) Otros personajes también le ofrecieron fuego, le hicieron reverencia con hojas de palma, y durante la ceremonia el Señor 6 Agua Cuchillo de Pedernal tocó el caracol, instrumento ritual.

Las páginas 5 a 7 del códice abordan la genealogía del Señor 8 Viento, se representa en éstas del primer matrimonio hasta el tercero y el nombre y representación de sus 24 hijos e hijas, entre los cuales ocupa el lugar 18 el Señor 5 Movimiento, Águila Roja de Tabaco Ardiente representado en la página 7 pintura 3. (Fig. 48)

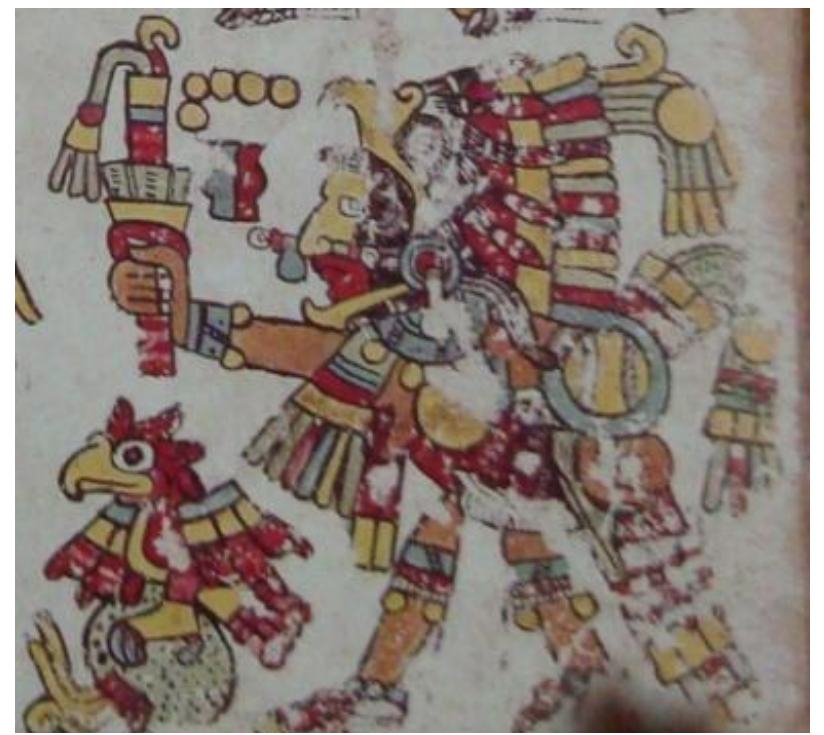

Figura 48 Lámina 7 pintura 3. El señor 5 Movimiento, Águila Roja de Tabaco Ardiente.

Las páginas 8 a 10 del códice tratan los linajes relacionados con el Señor 8 Viento, el matrimonio del señor 9 lluvia con fuego en la mano que tomó por esposo la Señora 6 Lluvia. En este episodio se menciona y dibuja al Señor 4 Agua, Jaguar de Cuya boca Sale Vapor, con polvo de tabaco en la mano (Fig 49). 


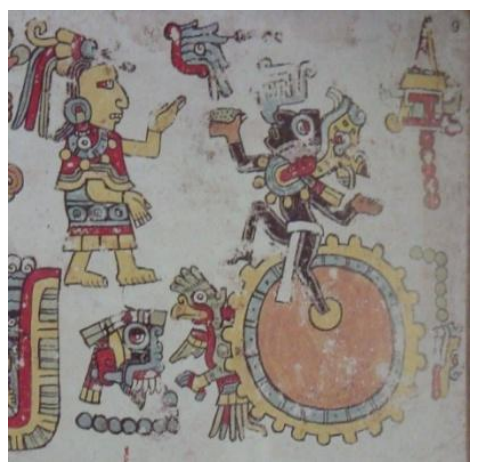

Figura 49 Lámina 9 pintura 5. Señor 4 Agua, Jaguar de Cuya boca sale vapor

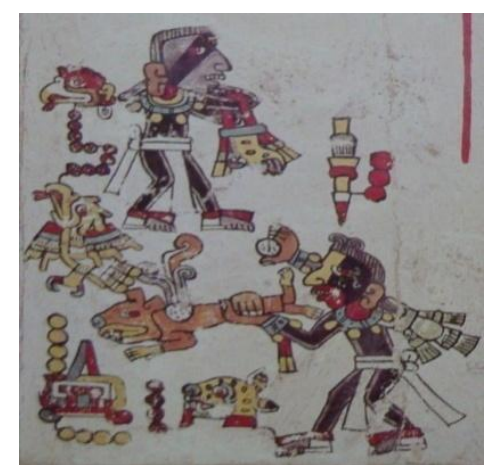

Figura 50 Lámina 9 pinturas 17 y 18 Señor Caña, tiene polvo de tabaco en la mano y Señor 4 Jaguar quien quemaba tabaco en un Incensario en forma de animal.

En la misma página se relata la historia de la concepción y nacimiento de gemelos. En esta hoja indican que la Señora 5 Venado Joya del Dios de la Lluvia, se bañó en un rio que se localizaba frente a una cueva. Ella cubría su parte íntima con un cuchillo de pedernal, entonces fue fecundada por el dios Sol, después dio a luz gemelos y fue a sentarse ante el Señor Sol en su Templo de la Flecha de Guerra en Cerro Encorvado Quetzal. Años después los gemelos se convirtieron en sacerdotes: uno el cargaba su bolsa de copal mientras que su hermano el Señor 4 Jaguar quemaba tabaco en un incensario en forma de animal (Fig. 50).

Las páginas 11 y 12 del códice tratan de la dinastía de Montes Nevados y el matrimonio de la Señora 3 Movimiento de la primera dinastía de Tilantongo. Los fundadores de este lugar fueron el Señor 1 Jaguar y la Señora 1 Flor uno de sus tres hijos fue el Señor 7 Caña, Antorcha de Tabaco Ardiente que se casó con la Señora 7 hierba, Estrella de Fuego y Humo (Fig. 51). Otro de los hijos de esa pareja fue el Señor 10 Mono Jaguar que se casó con la Señora 1 Agua, Veinte Ruecas y uno de sus hijos el Señor 7 Mono, Lanza 
Dardos Precioso fue aclamado como rey y el Señor 3 Flor, Príncipe dedicado al fuego le ofreció tabaco (Fig. 52)

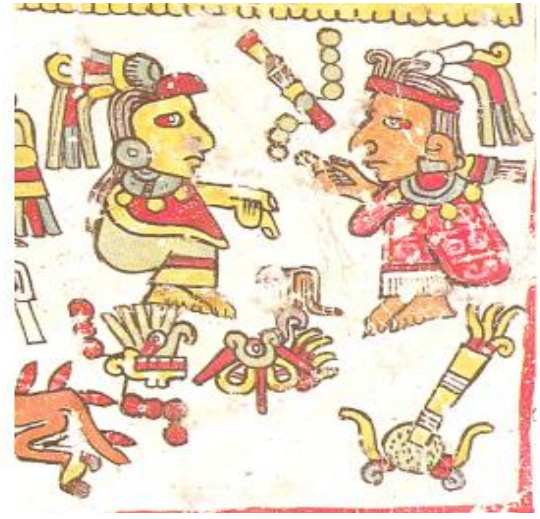

Figura 51 Lámina 11 pinturas 14 Señor 7 Caña Antorcha de Tabaco Ardiente esposo de la señora 7 hierba

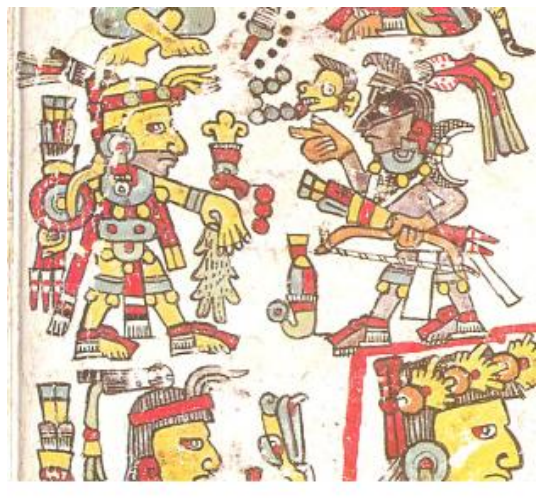

Figura 52 Lámina 20 Señor 3 Flor, Príncipe dedicado al fuego ofreciendo tabaco.

Las páginas 14 a la 22 muestran la historia del la Señora 3 Pedernal (hija) y del Señor 12 Viento. La pagina 14 trata de los seis lugares primordiales. Indica que estuvieron en uno de esos lugares en la Peña del Águila y Ciudad del Monte de Fuego los dos ancianos cargadores de bules de tabaco el Señor 10 Lluvia, Jaguar que respira fuego y el Señor 10 Hierba, Jaguar que respira fuego. Los dos cargaban en su mano una jícara preciosa con ofrenda de rajitas de ocote y hule (Fig. 53) 


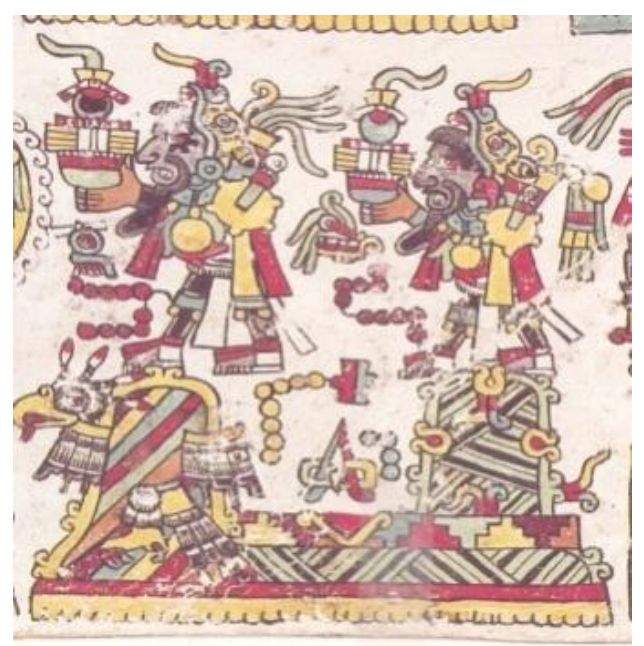

Figura 53 Lámina 14 Dos ancianos cargadores de bules de tabaco:

Pintura 8: El Señor 10 Lluvia "Jaguar que respira fuego" y

Figura 9: el Señor 10 Hierba "Jaguar que respira fuego".

En la página 15 mencionan que el Señor 5 Flor y la Señora 3 Pedernal (madre) iniciaron su peregrinación. Entre los personajes que los acompañaron estaban los ancianos cargadores de los bules de tabaco el Señor 10 Lluvia y el Señor 10 Hierba quienes de la misma manera que en la lámina anterior traían jícaras preciosas con ofrendas de rajitas de ocote y hule (Fig. 54).

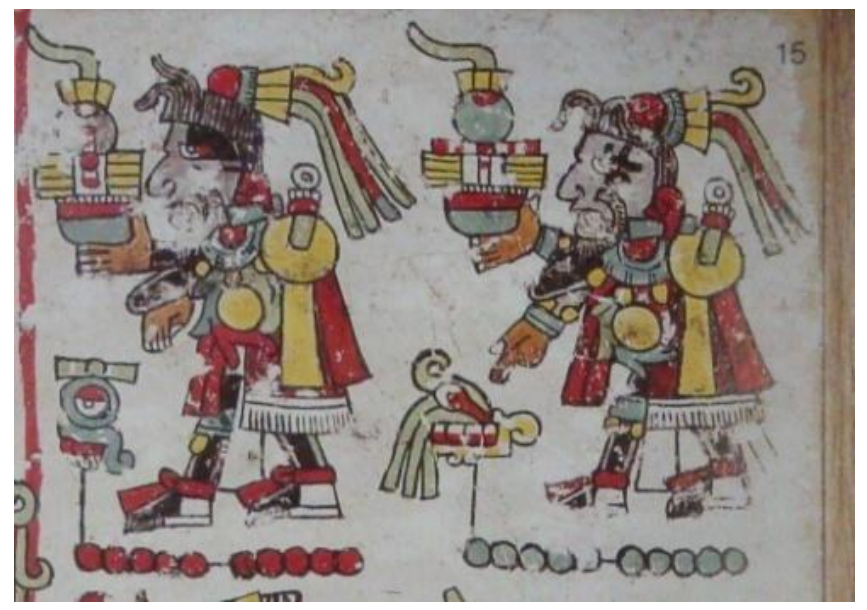

Figura 54 Lámina 5 figuras 5 y 6 ancianos cargadores de los bules de tabaco el Señor 10 Lluvia y el Señor 10 Hierba 
La página 16 nos muestra el nacimiento y peregrinación de la Señora 3 Pedernal (hija) quien llegó a ser reina en el Templo de la Serpiente emplumada. Algunos personajes observaban como se prendía el temazcal para que se bañara su madre, parturienta y mandaron poner una ofrenda para la patrona del baño: Era una vasija con rajitas de ocote y hule y un haz de varitas sagrado dedicado a Xipe y un haz de varitas verdes atadas con papel. Entonces nació la Señora 3 Pedernal que se llamó Quechquemitl de Jade y su madre la Señora 3 Pedernal tomó la forma de su nahual, Serpiente Emplumada; se metió en una cueva dentro de una peña en un rio subterráneo y se transformó en el Río de la Ceniza que brotó de la roca, éste era rico en fauna acuática y estaba guarnecido por árboles. A los lados del río estaban el anciano cargador del bule de tabaco el Señor 10 Hierba (Fig. 55) y otros sacerdotes.

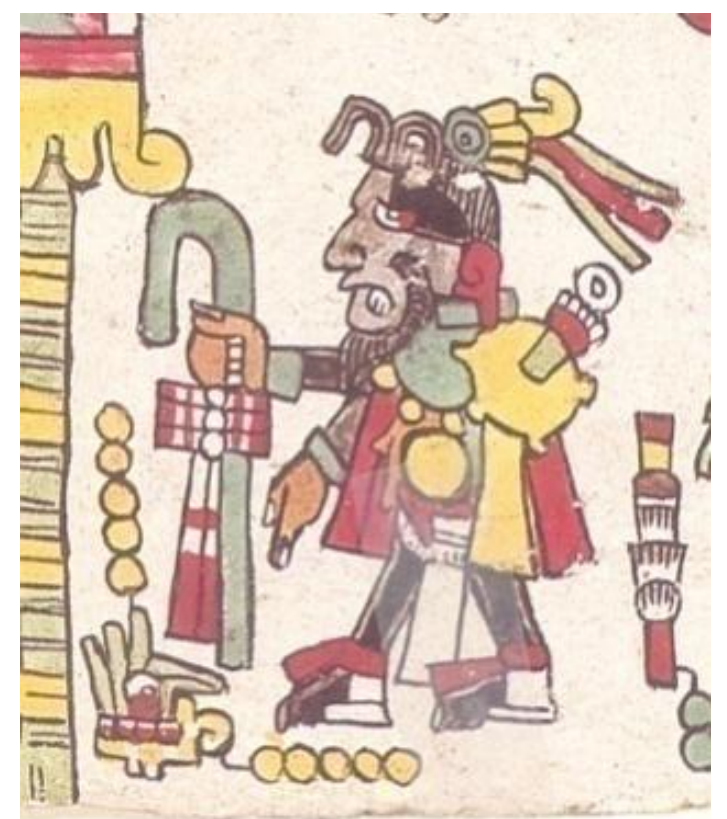

Figura 55 Lámina 16 pintura 12, Anciano Cargador del Bule de Tabaco "Señor 10 Hierba" 
La pagina 17 relata cómo la Señora 3 Pedernal participó en una ceremonia y recibió las enseñanzas de su padre el Señor 5 Flor y de los ancianos cargadores del Bule de tabaco Señor 10 Hierba y Señor 10 Lluvia. Después fue instruida por otros personajes y se realizó una gran ceremonia en donde el Señor 9 Flor ofreció y encendió el fuego (Fig. 56) y el Señor 10 Hierba hizo una ofrenda de una codorniz y jícara con rajitas de ocote y hule ante un altar grande.

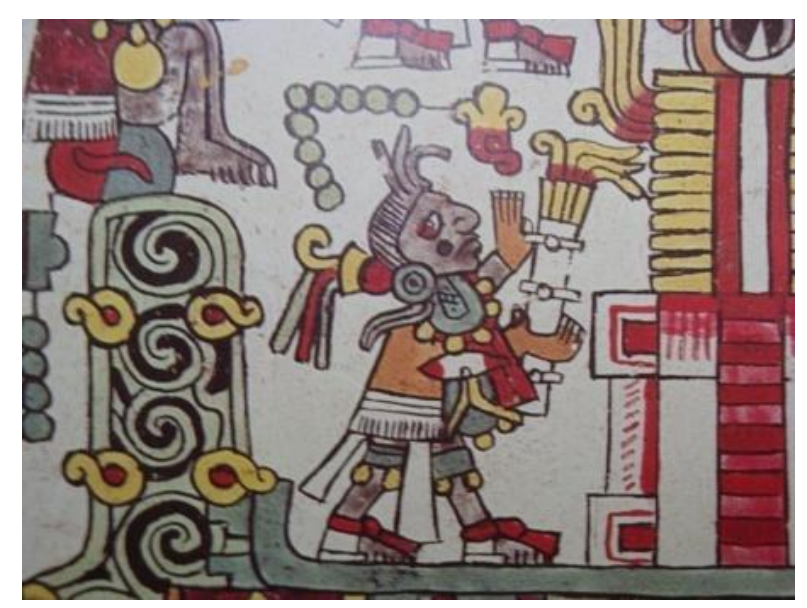

Figura 56 Lámina 17 pintura 7. El Señor 9 Flor

En la página 18 aparece en el puesto 1 el Señor 2 Perro, Cargador del Bule de Tabaco (Fig. 57) quien formó parte de la ceremonia en la que la joven Señora 3 Pedernal tomó el poder como reina. Durante la ceremonia ella se sentó sobre un cojín de piel de jaguar y su padre el Señor 5 Flor sobre una piedra, era el sacerdote que la educaba y ella recibió siempre sus consejos dentro del palacio. 


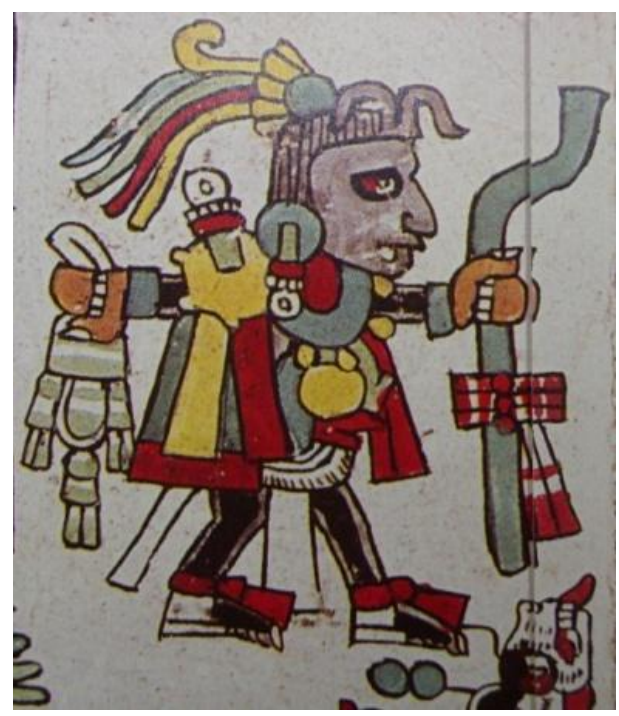

Figura 57 Lámina 17 pintura 1 Señor 2 Perro Cargador del Bule de Tabaco.

Las páginas 19 a y 19 b dan cuenta del casamiento de la señora 3 Pedernal con el señor 12 Viento Ojo que Humea, quien recibió el encargarse del templo y del Fuego Nuevo, señal de fundación del nuevo señorío. Entre su comitiva se encontraba el Señor 9 Movimiento Antorcha de Tabaco Ardiente, como cargador del caracol (Fig. 58).

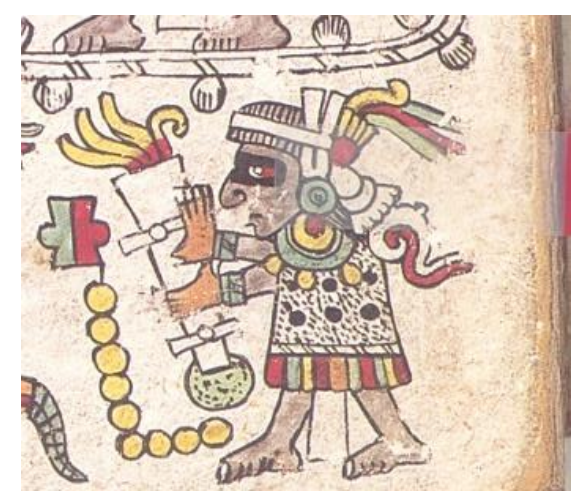

Figura 58 Lámina 19 a El Señor 9 Movimiento Antorcha de Tabaco Ardiente como el Cargador de Caracol. 
El Señor 12 Viento fue recibido por los ancianos cargadores del bule de tabaco El Señor 10 Hierba y el Señor 10 Lluvia (Fig. 59).

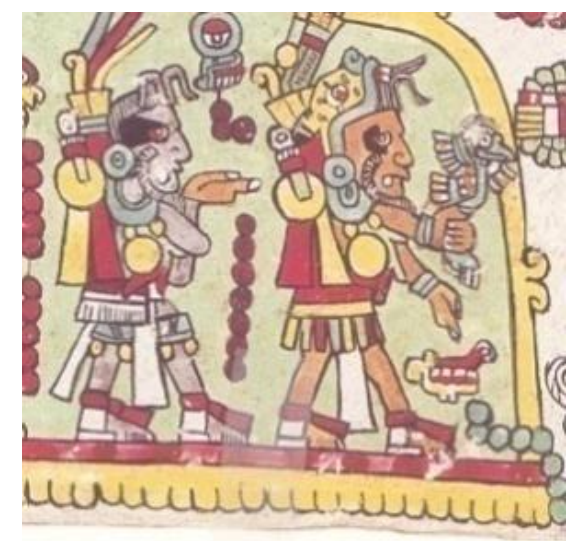

Figura 59 Lamina 19a pinturas 13 y 14 Ancianos cargadores del bule de tabaco

Explican cómo la Señora 3 Pedernal fue cargada sobre la espalda del Señor 6 Agua, quien empuñaba un bastón, mientras el Señor 6 Muerte lo seguía con flores de maguey y le ofrecieron la vestimenta ceremonial, hierbas y una bolsa de copal. Por el camino iban otros personajes que traían el fuego y otro más que hacía sonar el caracol. También la acompañaba el anciano cargador del bule de tabaco el Señor 7 Flor quien portaba un incensario y una sonaja (Fig. 60)

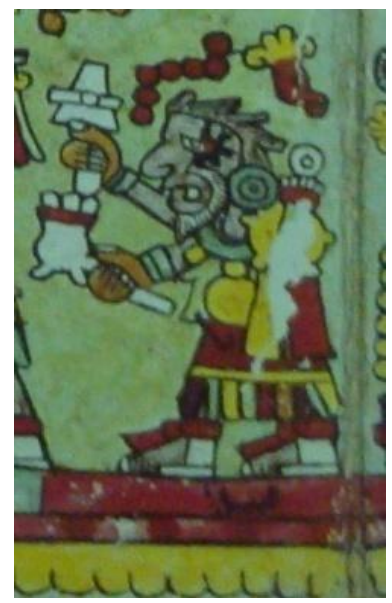

Figura 60 Lamina 19b pintura 27 Anciano cargador del bule de tabaco Señor 7 Flor 
La ceremonia se celebró en una cueva en donde los novios, sentados en cuclillas sobre palma verde fueron bañados con jícaras por las Señoras 10 Casa y 6 Pedernal, después les dieron una cobija. Ya estaban colocados los símbolos del señorío al pie del cerro Blanco de Pedernales: un envoltorio sagrado con el rollo de papel (códice) y el instrumento para taladrar el fuego nuevo así como el cuchillo de pedernal. Después los recién desposados se acostaron bajo la cobija que habían recibido.

Se habian colocado en el suelo manojos de palma verde envueltos en papel.El anciano cargador del Bule de tabaco, Señor 10 lluvia Jaguar se sentó sobre el trono, ocupó un puesto de gran autoridad y hacía ofrendas al Abuelo 1 Hierba: una codorníz y una jícara. (Fig. 61)

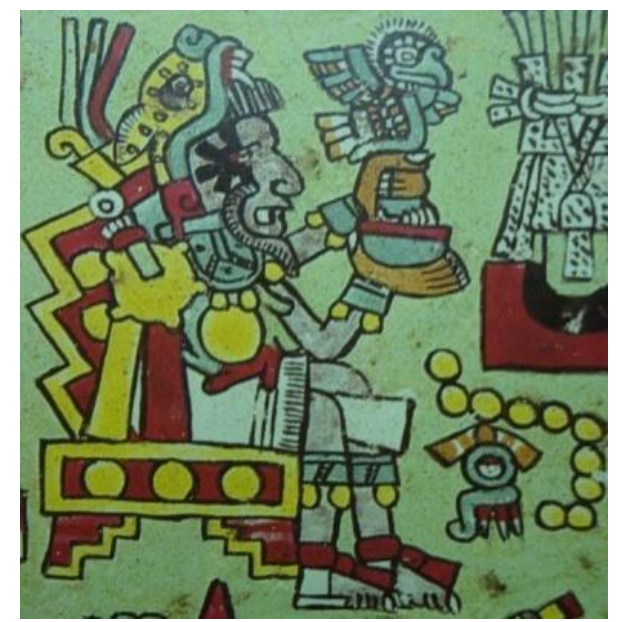

Figura 61 Lámina 19 b pintura 42.EI Señor 10 Lluvia Jaguar.

Tal parece que la guerra contra la gente de piedra era constante, es dibujada también en las páginas 20 y 21 del códice. En estas hojas se relata una ceremonia mortuoria. Los guerreros que cayeron muertos eran la Señora 12 Zopilote y el Señor 12 Lagartija y fueron 
entregados a la sacerdotisa que cuida a los difuntos. Tambien murieron sus hijos el señor 4 Casa y el Señor 3 Mono. Sus cuerpos fueron secados y ahumados sobre el fuego, en esta ceremonia el Señor 10 Hierba les hizo música con una sonaja preciosa y el anciano cargador del bule de tabaco Señor 10 lluvia Jaguar les cantó la canción del Señor 7 Flor.

Se observa en este códice que los cargadores del bule de tabaco generalmente eran ancianos que ocupaban lugares importantes en ceremonias como la decapitación, este acontecimiento se dibuja en la página 21. El Señor 10 lluvia (Fig. 62) hizo el rito de la decapitación junto con el sacerdote Señor 10 caña.

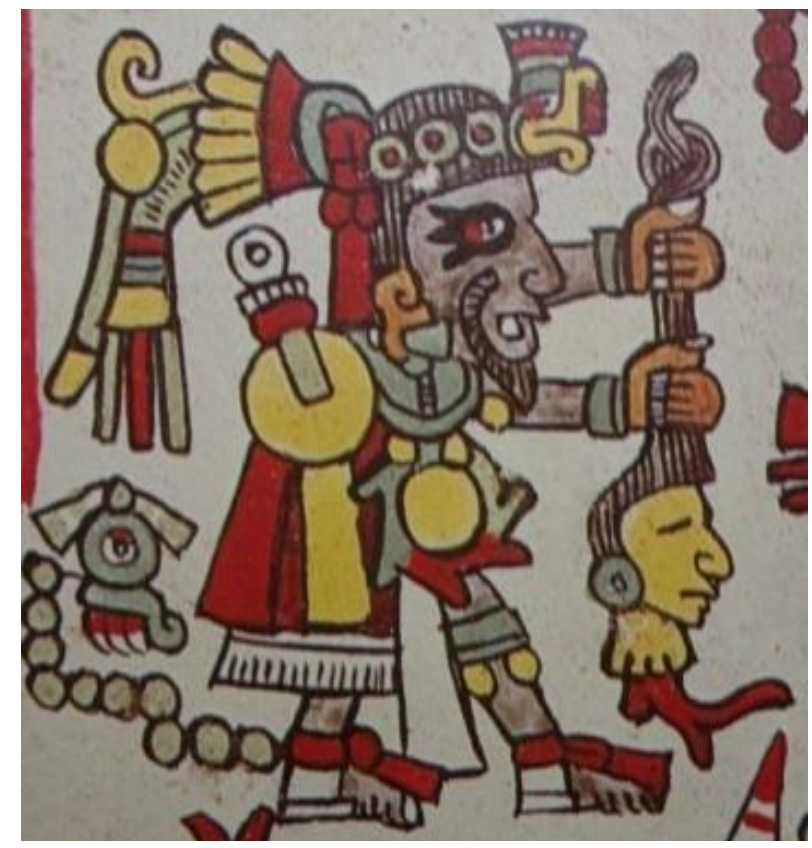

Figura 62 Lámina 21 pintura 1. Anciano cargador del bule de tabaco. En la ceremonia de decapitación

En las láminas que corresponden a los reyes de Tilantongo, principalmente en la 25 observamos que debido a las guerras y para lograr alianzas, cuando un pueblo era sojuzgado por otro, al paso del 
tiempo, cuando se asentaba el gobierno sobre los derrotados, los lazos familiares se iban entretejiendo.

Observamos que en las ceremonias de nombramiento de los sacerdotes, cargo que fue otorgado al padre de 8 Venado, llamado Señor 5 Lagarto, cuando lo visitan los sacerdotes para investirlo, le rinden homenaje, le hablan con respeto y le ofrecen tabaco (Fig. 63). En este caso el nombramiento fue de Sacerdote de la Muerte.

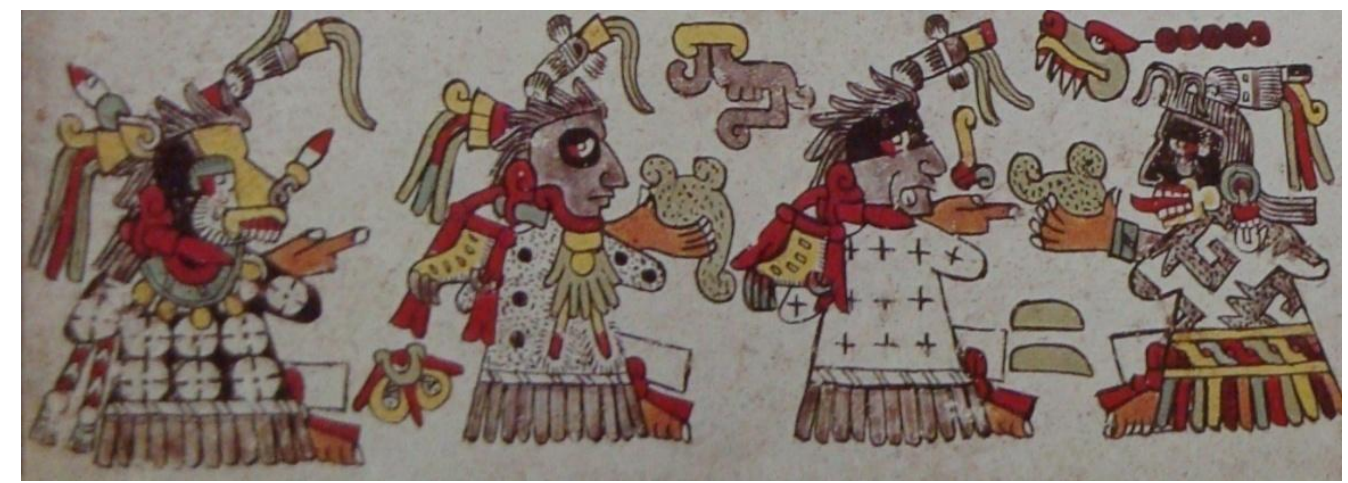

Figura 63 Lamina 25 pinturas 11,12 y 13 el Señor 5 lagarto recibe a los sacerdotes que le rinden homenaje con tabaco.

Entre los reyes de Tilantongo se encontraban el Señor Lagarto y durante su segundo matrimonio, con la Señora 11 Agua Pájaro Precioso nació el Señor 9 Flor, Antorcha de Tabaco Ardiente. (Fig. 64) 


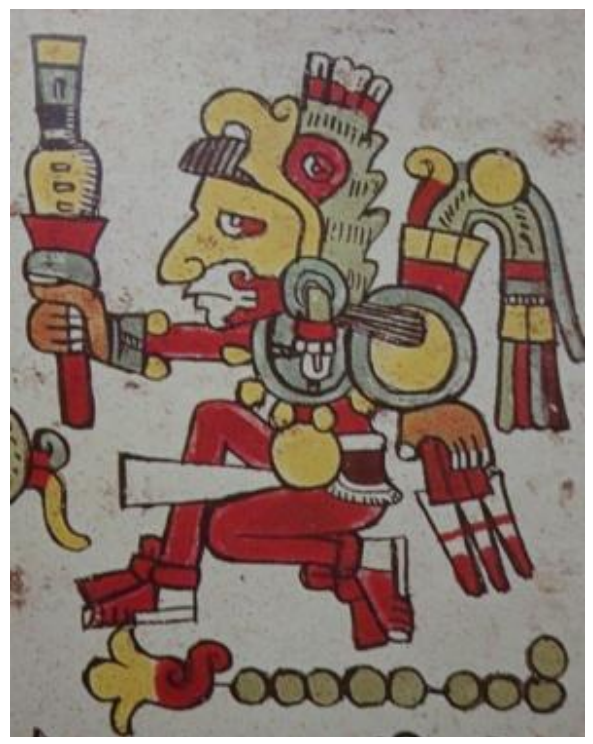

Figura 64 Lamina Señor Nueve Flor Antorcha de Tabaco Ardiente

Una de las hijas de 8 Venado nació durante su cuarto matrimonio: fue la Señora 2 Hierba, Joya de Tabaco Ardiente. (Fig. 65)

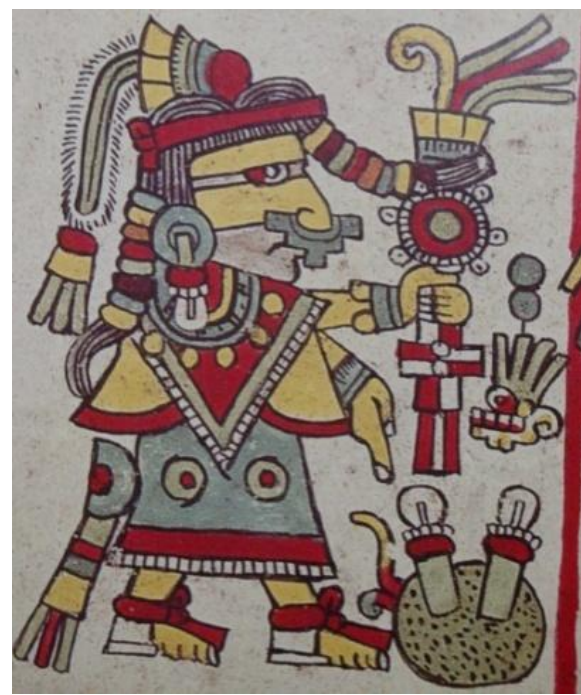

Figura 65 Lámina 27 pintura 8. Señora 2 Hierba Joya de Tabaco Ardiente 
La Señora 11 agua fue la segunda esposa de 5 Lagarto y el segundo hijo de este matrimonio fue el Señor 9 Flor, flecha de Tabaco Ardiente. (Fig. 66)

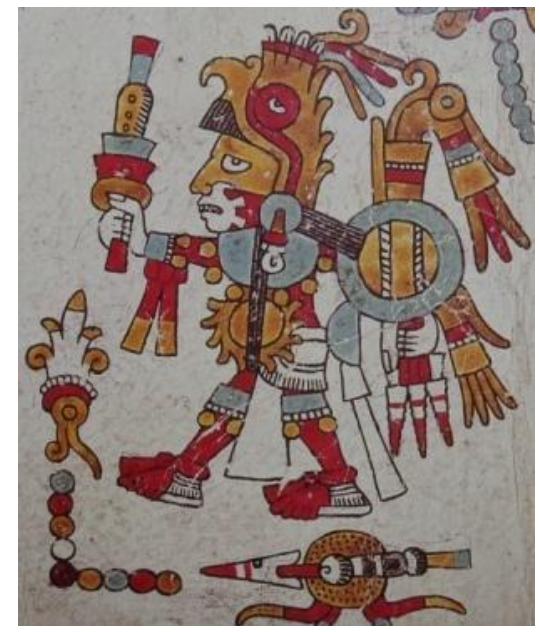

Figura 66 Lámina 43 pintura 2 Señor 9 Flor Flecha de Tabaco Ardiente.

En las peregrinaciones religiosas y ceremonias de 8 Venado ocupaban un lugar importante los sacerdotes, los ancianos cargadores del bule de tabaco quienes se encargaban de realizar adoraciones.

Las páginas 81 y 82 del Nuttall son particularmente interesantes. La pagina 81 relata que 12 Movimiento, Jaguar Sangriento, medio hermano de 8 Venado, se bañó en el temazcal en donde se realizaban las limpias rituales. 12 Movimiento iba acompañado de otro hombre quien debía poner agua en las piedras para formar vapor y llevar hierbas para "ramearlo", como se hace todavía en las "limpias" rituales. Una vez solo con el príncipe lo asesinó. Esto representaba traición y sacrilegio en el temazcal (Fig. 67). El cuerpo de 12 Movimiento se colocó sobre un armazón de 
madera puesto en tierra, se decoró con papel y plumas rojas encima del fuego y ceniza caliente para realizar un bulto mortuorio y en la ceremonia los sacerdotes le rindieron homenaje ofreciéndo tabaco, una codorniz y el fuego de una antorcha (Fig.68).

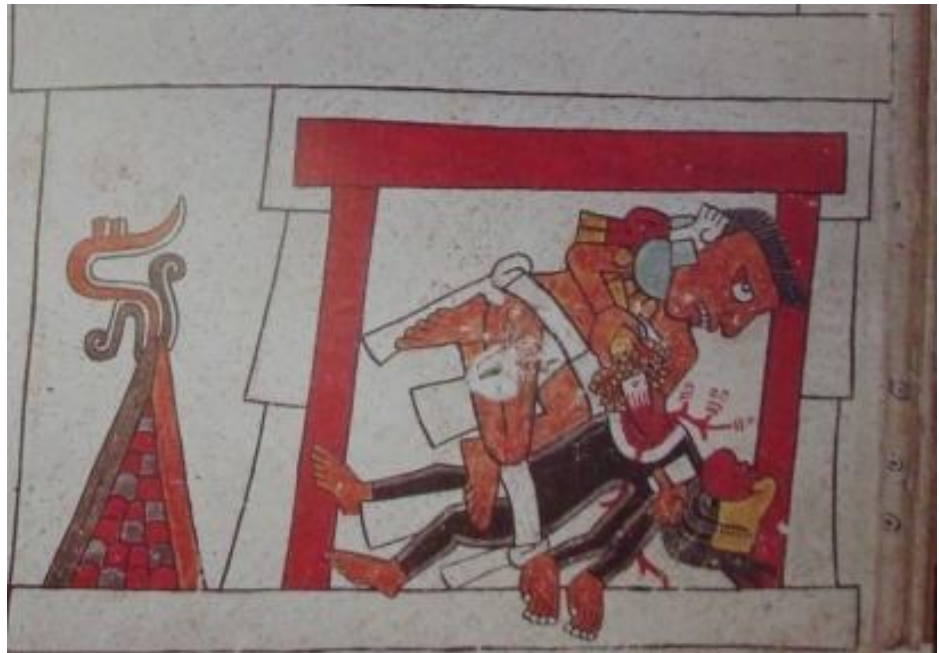

Figura 67 Lamina 82 pintura 1,2,3 Gráfica del asesinato de 12 Movimiento en el temazcal

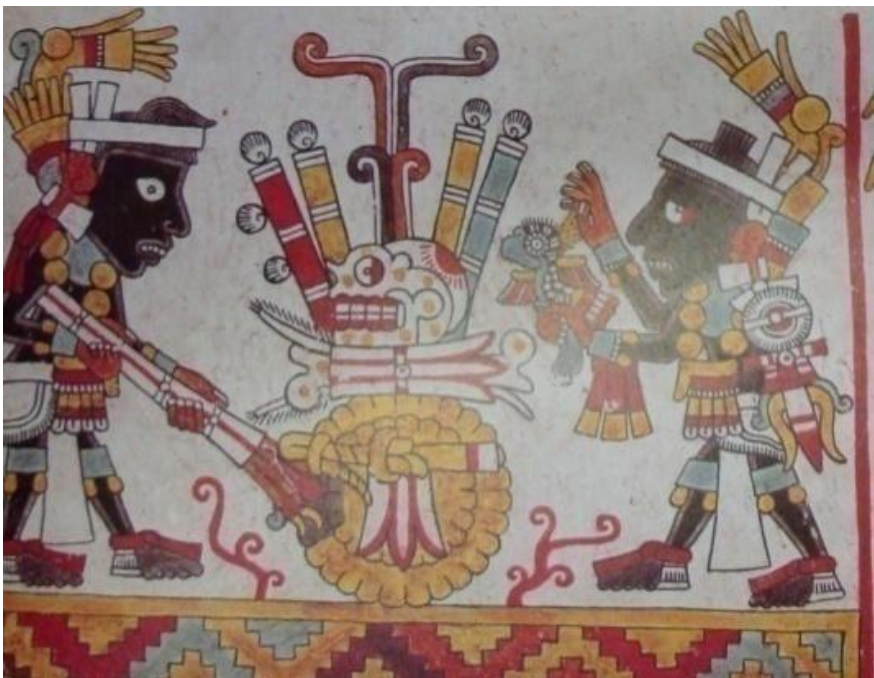

Figura 68 Lamina 82 pinturas 9,10,11 Los sacerdotes colocan el cráneo y huesos de 12 Venado sobre un rosetón lo adornaron y ofrecieron codornices y tabaco hicieron humear el rosetón con el fuego de la antorcha 
Los sacerdotes llegaron para entregar las ofrendas del Cerro Gordo, Loma de la Flecha y Ciudad del Jaguar (Fig. 69)

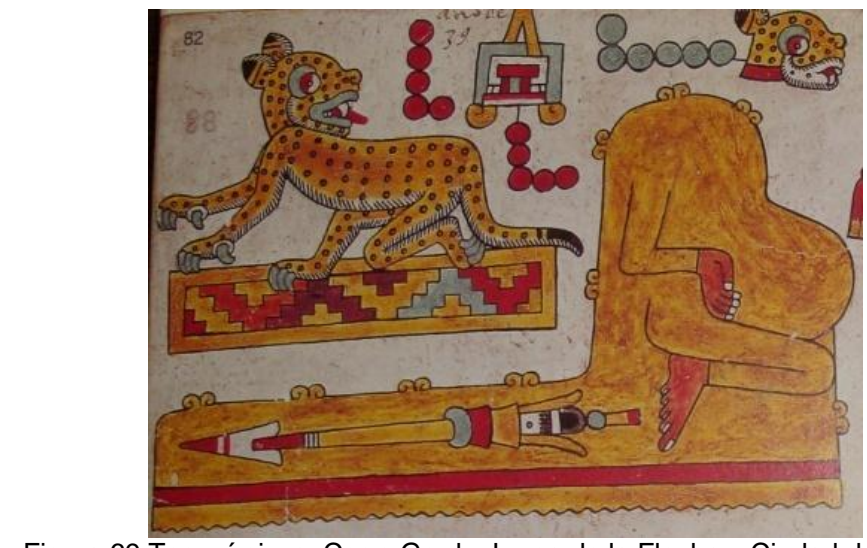

Figura 69 Toponímicos: Cerro Gordo, Loma de la Flecha y Ciudad del Jaguar.

365 dias después del asesinato en el temazcal el Señor 8 Venado inició su campaña de venganza. Culpó a los dos hijos de su media hermana, los apresó, y luego los hizo ejecutar. Otro de los presos el Señor 4 Viento se echó a llorar y 8 Venado lo dejó con vida. Algunos autores opinan que tal vez el Señor 8 Venado fue el autor del asesinato de su medio hermano, porque así pudo monopolizar el poder, quedando liberado de su principal competidor: su medio hermano mayor 12 Movimiento y sus dos sobrinos que eran los dos últimos descendientes masculinos del primer matrimonio de su padre. Es la última página del códice la única que reproducimos completa. (Fig. 70) 


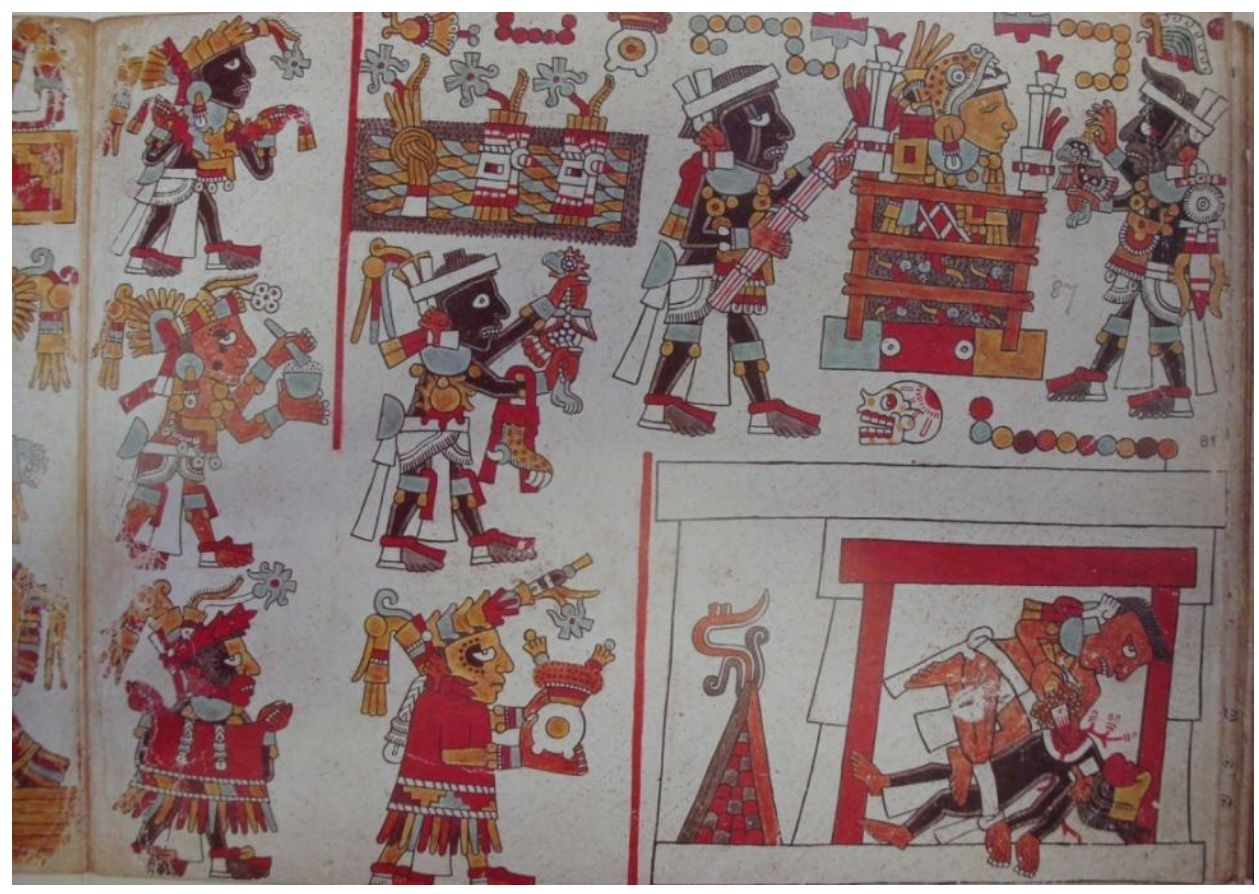

Figura 70 lámina 81.

Las diferentes tribus de México prehispánico tenían una relación muy particular en torno al tabaco y a las deidades; el fuego y el humo. En el área de Michoacán por ejemplo, la vida religiosa se realizaba alrededor de las fogatas, el principal oficio del Señor tarasco, era traer leña para abrasar las fogatas del templo, por lo que era considerado Fogonero Supremo y Sacerdote Mayor, era el encargado de encender el fuego, por lo que se le denominaba "Teniente del Dios Curicaueri".

El sahumerio era en general importante entre las tribus indígenas debido a que el humo era el único contacto entre los hombres y el cielo, era alimento de los dioses. Como los sacerdotes y señores eran representantes de la divinidad podían fumar con largas pipas de barro, ellos al igual que los dioses debían alimentarse 
de humo, ofrendaban al dios del fuego bolitas de tabaco que arrojaban a la lumbre, con el objetivo de que el humo oliera bien..$^{38}$

Creo que también la manera de ver "la palabra" era a través del humo que se exhalaba al pronunciarla.

No solamente en los códices se retomaba la cuestión del tabaco, con el descubrimiento de la Nueva España algunos frailes como Bernardino de Sahagún, Bartolomé de las Casas, Mendieta y otros escribieron sobre el particular. Sahagún comentaba que los indios bailaban una danza llamada tecomapiloloya, en Teopeopulco, durante la gran fiesta de la "barredura". Esta fiesta duraba varios días, los reyes y príncipes se presentaban en el papel de magos y llevaban colgada sobre el hombro una calabaza de tabaco ${ }^{39}$ Este autor también narra que Opochtli era adorado y uno de los habitantes del paraíso terrenal, aunque sabían que era hombre, le atribuían la invención de las redes para pescar, los remos etc. Cuando le hacían una fiesta, los pescadores le ofrecían cañas de maíz verdes, flores y cañas de humo que llamaban Yetl. ${ }^{40}$

El tabaco también se utilizó en prácticas adivinatorias o augurios, para comunicarse con los espíritus, en estado de trance ó para averiguar cosas ocultas. Los indios lo mezclaban con otras hierbas y minerales para que al fumar pudieran conocer, por ejemplo las causas de alguna enfermedad, las catástrofes naturales en las que se revelaba la ira de algún dios, la suerte de la cosecha, los

\footnotetext{
${ }^{38}$ José Coroña Núñez. Mitología Tarasca. México, FCE, 1957 p. 15

${ }^{39}$ Cfr. Seler Eduard Comentarios...Op. cit. Los veinte signos de los días y sus deidades. Tomo I, p. 118

${ }^{40}$ Bernardino de Sahagún. Historia de las Cosas de la Nueva España. Capítulo XVII del Libro I. México, Porrúa, 1977 p. 44
} 
resultados de la guerra, etc. Observamos que la planta tenía muchas funciones y se consideró un elemento importante en todo el ciclo de vida, por ejemplo: a las mujeres embarazadas les aplicaban picietl en el seno para tener un embarazo feliz y librar a su futuro hijo de enfermedades, antes y después del alumbramiento la familia se reunía para inhalar tabaco. Mendieta ${ }^{41}$ asocia el tabaco con Ciuacoatl mujer serpiente quien era la deidad del embarazo y del nacimiento, con ella la planta se asociaba con lo vital.

No podemos abordar todo lo que pasaba en el mundo indígena con relación al tabaco, pero en la teología maya se describe la forma en que los dioses y los sacerdotes lo utilizaban en ritos de adoración o súplica al dios solar. Aún cuando en la península de Yucatán, las mujeres lo ofrendaban en el templo antes de casarse, el tabaco se vincula en general y de manera más directa con los hombres: fue un amuleto protector para la caza, la guerra y otras actividades peligrosas; era considerado hechizo contra enemigos; unido con plumas de águila y flechas ensangrentadas, fue un símbolo para declarar hostilidades; se otorgaba como homenaje al guerrero que regresaba de una campaña; era un rito del campesino para lograr el beneficio de la lluvia; se utilizó en dedicación de templos, entierros, aniversario de fallecimiento, ofrendas funerarias, etc. Además le acompaña magia y poesía, cuando se define que Chac -dios de la lluvia- era gran fumador, que prendía su tabaco con rayos y truenos y cuando los tiraba encendidos aparecían los cometas ${ }^{42}$

\footnotetext{
${ }^{41}$ Mendieta Jerónimo de Fr. Documentos para la Historia de México p. 26

${ }^{42}$ Manuel González Galván El tabaco y las....Op. Cit.
} 
En Chiapas, región maya, entre los indios Tzotziles existió esta creencia: Si el tabaco se untaba sobre el cuerpo, no se acercaba Pucuh, uno de los dioses de la muerte, así la planta preservaba la vida. Actualmente es común para esta etnia fumar tabaco, en el campo, porque el humo ahuyenta a los mosquitos.

\subsubsection{El tabaco como medicina y como repelente.}

Como los sacerdotes aztecas se aplicaban sobre el cuerpo las cenizas del tabaco mezcladas con otras sustancias, fue considerado teopatli una especie de medicamento divino, se usó como digestivo por sus efectos vomitivos, laxantes o purgantes; expectorante oliendo las hojas verdes; absorbiéndolo seco o en polvo por la nariz, para el catarro y otras afecciones respiratorias; como desinfectante aplicándolo sobre la mordedura de serpientes después de sajar, chupar y cauterizar la herida ${ }^{43}$ y ¡remedio eficaz para ahuyentar a las culebras:

\footnotetext{
"Hay una serpiente muy grande que se llama aueiactli; es larga como una viga de diez brazas, tiene cascabeles en la cola, ó eslabones; tiene dientes y colmillos, es muy deleznable, es parda oscura, es del color de la culebra que se llama tlilcóatl; tiene el pecho como amarillo, tiene el hocico colorado, es ponzoñosa y su ponzoña no tiene remedio(....) los que conocen ya esta culebra o serpiente, llevan muchos papeles hechos como pelotas y llenos de picirtl molido y tíranle con ellos o llevan unos jarrillos llenos de esta misma hierba, y tíranle con ellos, y como se quiebra el jarrillo y se derrama el picietl, con el polvo del picietl se emborracha y se adormece; y de que está adormecida, con un palo o vara larga métenla en la boca una manta en que va revuelta aquella hierba picietl, molida, y entonces pierde todo el sentido y así la matan. Y llegase esta culebra a los manantiales de las aguas, y allí come y traga cuantos peces y animales hay". ${ }^{44}$
}

Además el tabaco era utilizado en compresas sobre heridas, emplastos o ungüentos y como calmante para dolores físicos no intensos, pero tal parece que el objetivo de usar tabaco, residía en

\footnotetext{
${ }^{43}$ Bernardino de Sahagún Fr.,Op. Cit.. Libro XI, p 652

${ }^{44}$ Ibid. Pp 272-273
} 
ahuyentar a los espíritus que causaban las enfermedades, más que en aliviarlas.

\subsubsection{Usos ceremoniales.}

Dentro de la organización de los pueblos aztecas, los sacerdotes tenían un gran poder político por lo que muchas ceremonias religiosas no eran tales; cuando se investía un nuevo monarca con las insignias de autoridad, recibía el yetecomatl repleto de tabaco. En la diplomacia azteca aparece siempre la pipa tubular como antes con los mayas y después en casi toda Norteamérica. Se ofrecía a todo embajador o emisario de calidad, incluyendo a los nuevos exploradores españoles. Las flores xochitl y el tabaco acayetl constituían la forma de saludo.

En algunos ritos funerarios el tabaco se utilizaba después de haber sacrificado a algunas víctimas y un año después de haberlos enterrado realizaban el siguiente rito:

“....cada año hacían memoria ante la caja y hacíase sacrificar codornices, aves y mariposas y conejos; ponían también incienso y ofrenda de comida e vino e rosas e unos cañutos o cañas que dicen acalyét ${ }^{45}$, que son unas cañas de dos palmos llenas de cierta confección odorífera, cuyo humo reciben por la boca y dicen ser bueno para la cabeza" ${ }^{46}$.

Por ser utilizado en ceremonias políticas, diplomáticas, militares y sociales el tabaco no dejaba de tener un carácter religioso, pero como abundaba en muchas regiones de México, en forma silvestre y cultivada, la tendencia de las ceremonias rituales para crear hábitos, por medio de su repetición, aunado a la propiedad de la nicotina de

\footnotetext{
45 Tabaco significa yetl en idioma Nahuatl.

${ }^{46}$ Bartolomé de las Casas Fr. Los indios de México y Nueva España. Antología. México, Porrúa, 1993. p 184
} 
crear hábito en el organismo, motivó el carácter profano del tabaco para satisfacción del consumidor ${ }^{47}$.

Narra Fray Bernardino de Sahagún que en Tochtepec cuando un mercader invitaba a otros a comer les daba tabaco:

\footnotetext{
"Los convidados venían a la medianoche a la casa del convite; estando ya todos juntos dábanles agua manos, y luego les servían comida, comían todos. Acabada la comida otra vez lavaban las manos y la boca, y luego los ponían la bebida del cacao y luego cañas de humo; después de esto les daban mantas, flores y otras cosas"48.
}

Resulta contrastante la motivación de los hombres prehispánicos al usar el tabaco en contra de la enfermedad, cuando en el siglo XXI los fumadores desean dejar el tabaco debido a la enfermedad que les causa.

Aun cuando en la época prehispánica la producción, el uso y consumo del tabaco eran notables en las etiquetas comerciales no se ve reflejado este enfoque. Algunas etiquetas hacen mención a los mexicanos, a los aztecas etc. $\mathrm{Y}$ algunas otras tienen dibujos como grecas prehispánicas pero ni las deidades ni el yetecómatl han sido utilizados en el diseño de las etiquetas.

\subsection{EL TABACO DURANTE LA CONQUISTA.}

Diversos autores abordaron el tema del descubrimiento de América de las actividades en torno a la conquista de México, los tipos de tabaco, la descripción de la planta, su utilización etc. Se relata que cuando Hernán Cortés desembarcó en las Antillas vio con

\footnotetext{
${ }^{47}$ Ibidem. p. 22

${ }^{48}$ Bernardino de Sahagún Fr. Op. Cit.. Tomo III p.47
} 


\title{
curiosidad y sorpresa que los nativos chupaban o comían humo de
} unos canutos:

\begin{abstract}
"Fallé un hombre solo en una almadia, que se pasaba de la isla de Santa María a la Fernandina, y traía un poco de pan que sería como un puño, y una calabaza de agua, y un pedazo de tierra bermeja, hecha en polvo y después amasada y unas hojas secas, que debe ser cosa muy apreciada entre ellos porque ya me trujeron en San Salvador dellos en presente"

“...hallaron dos cristianos por el camino mucha gente que atravesaba a sus pueblos, mujeres y hombres, con un tizón en la mano, yerbas para tomar sahumerios que son unas hierbas secas metidas en una cierta hoja, seca también a manera de mosquete hecho de papel, de los que hacen los muchachos en la Pascua del Espíritu Santo, y encendida por la una parte dé, por la otra chupan o sorben o reciben con el resuello para adentro de aquél humo con el cual se adormecen las carnes y cuasi emborracha y así diz que no sienten el cansancio. Estos mosquetes o como les nombraremos llaman ellos tabaco." ${ }^{49}$
\end{abstract}

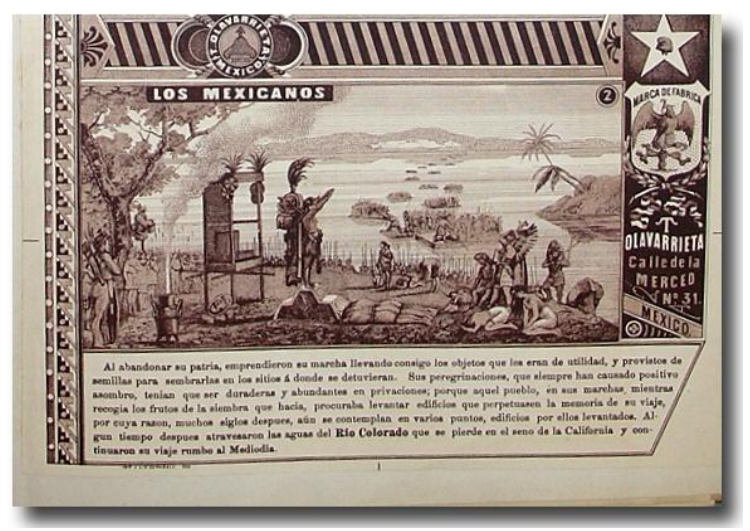

Figura 71 Etiqueta. "Los Mexicanos" Olavarrieta Calle de la Merced No. 31.

André Thevet estuvo en Brasil en 1555 e hizo la primera descripción de la planta y sus aplicaciones medicinales ${ }^{50}$ en ese lugar se le denominaba petún aún cuando Bernal Díaz del Castillo ya se había referido a la planta como tabaco. ${ }^{51}$ Los españoles adoptaron la voz indígena tabaco y Gonzalo Fernández de Oviedo en 1635 hizo

\footnotetext{
${ }^{49}$ Bartolomé de las Casas Fr. Historia de las Indias, Lib. III Cap. CXII. México F.C.E. , 1951 p. 213

${ }^{50}$ Cfr. André Thevet "La Cosmographie Universelle”, 1575 en: El tabaco y las cigarreras de oro y plata Op cit. $\mathrm{p} 23$

${ }^{51}$ Bernal Díaz del Castillo, Historia Verdadera de la Conquista de la Nueva España. Caps. XCI y XCII México, UNAM, 1953
} 
también la descripción de la planta. Según los cronistas, los aztecas llamaban al tabaco picietl o yett, pero consideraron que el nombre procede de la isla La Española y se refería al utensilio para usarlo, más que a la planta:

\begin{abstract}
"De los tabacos o ahumadas que los indios acostumbraban en la isla Española(...).
Usaban los indios de esta isla entre otros sus vicios muy malo, que es tomar las ahumadas que ellos Ilaman tabaco para salir de sentido; y esto hacían con humo de cierta yerba que a lo que he podido entender de calidad de Veleño pero no de aquella locura o fe a la vista, porque esta yerba es un tallo como quatro cinco palmos poco mas o menos de alto y con unas hojas anchas y gruesas y blandas y vellosas; y el verde tira algo a la color de las hojas de lengua de buey Bulgosa: que llaman herbolarios y médicos. Esta yerba que digo, en el género es muy semejante al Veleño".
\end{abstract}

Bernardino de Sahagún consignó minuciosamente el nombre y usos del tabaco en el área náhuatl, en donde se conocía como yelt, el festival de Hitzilopochtli se festejaba en el día 1 pedernal y era cuando los aztecas ofrendaban paquetes de 20 puritos amarrados $^{52}$, pero observó que la planta provenía también de algunos lugares de las costas del Golfo, la variedad era más fina y delgada y se denominada piciet ${ }^{53}$ por otra parte Francisco Cervantes de Salazar, protomédico de Felipe II, señaló que además del picietl, el quauhxetl era de flor más blanca, tallo más redondo y hoja más lisa y larga; los purépechas lo llamaban andumuqua.

\begin{abstract}
"Es el yetl una hierba de raíz corta, delgada y fibrosa, de donde nacen tallos de cinco o más palmos de largo, vellosos, desordenados, estriados y lisos; hojas anchas, oblongas y hasta cierto punto parecidas al beleño que dejan, cuando caen, cápsulas semejantes también a las del beleño llenas de semillas. Llamaban los haitianos a esta planta tabaco (de los cuales se transmitió el nombre no solo a los indios sino también a los españoles), porque se mezclaba a los sahumerios que también llamaban tabacos. Algunos de entre nosotros lo llaman hierba sagrada y otros nicociana" ${ }^{34}$
\end{abstract}

\footnotetext{
${ }^{52}$ El numero 20 era sagrado entre los aztecas. En estas festividades el humo del tabaco se hermanaba con la del copal resina obtenida del "llanto de los pinos"

${ }_{53}^{53}$ Bernardino de Sahagún Fr. Op. Cit.

${ }^{54}$ Francisco Hernández, Historia Natural de la Nueva España (escrita entre 1571 a 1576). México, UNAM, 1959, Vol. I, p 80
} 
El protomédico aseguraba que si las hojas se secaban y luego se introducían por medio de cañutos o en canales de papel, se encendían por un lado y por el otro se introducían a la nariz o a la boca o si se aspiraba el humo manteniendo cerrada la boca y nariz provocaban expectoración, aliviaban el asma, la respiración difícil y sus molestias. Seguramente al exaltar los beneficios médicos del tabaco, propiciaba oficialmente su consumo. En fin, en la medida que los españoles avanzaban en la conquista y el conocimiento de nuevas tierras y comunidades, se encontraban con diferentes nombres asignados a las mismas cosas. En el caso de la planta cuyas hojas se torcían para fumar o se picaban para sorber el humo, por medio de cañas, o se machacaban hasta lograr polvo para esnifar, tenía un nombre distinto y también cada uno de los utensilios que lo acompañaban.

\subsubsection{Iconografía y descripciones del tabaco}

Nicolás Monrades ofrece el primer grabado conocido en España sobre la planta del tabaco (Fig. 72), el empeño de este doctor sevillano era propagar sus virtudes terapéuticas, no fue el único en ocuparse de la descripción y dibujo de la planta motivo de controversias. 


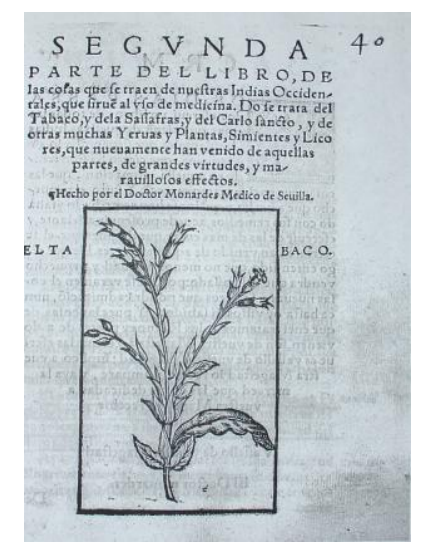

Figura 72 Grabado de planta de Tabaco. Nicolas Monrades

Mientras en México prehispánico era común fumar tabaco y utilizarlo, algunos autores como Fernández de Oviedo y Bartolomé de las Casas descalificaban el uso del tabaco debido a los efectos que causaba y que según sus crónicas eran difíciles de obviar en ceremonias y en la vida cotidiana. Sin embargo sus opiniones resultaban contradictorias con las de algunos recién llegados que se atrevían a sahumarse o esnifar tabaco, lo consideraron algo bueno, nuevo y fuerte; sin embargo, el uso fue privativo de esclavos, marinos y soldados.

\begin{abstract}
"En esta isla Española y en las comarcas tenían otra manera de yerbas como propias lechugas, y estas secaban al sol y al fuego y hacían de unas hojas de árboles secos un rollete como se hace un mosquete de papel y metían dentro un poco de aquella yerba y encendían el mosquete por una parte, y por otra sorbían o atraían el humo hacia dentro del pecho, lo cual les causaba un adormecimiento en las carnes y en todo el cuerpo de manera que ni sentían hambre ni cansancio, y estos mosquetes llamaban tabacos $(\ldots)^{55}$
\end{abstract}

Juan de Cárdenas (1591) negó la semejanza del tabaco con el Beleño por razones farmacológicas y en 1615 Francisco Hernández (quien estuvo en Nueva España entre 1570 y 1577) hizo un trabajo descriptivo y testimonia que existían al menos dos clases de tabaco ${ }^{56}$

\footnotetext{
${ }^{55}$ Bartolomé de las Casas, Apologética Historia sumaria de las Indias, México, UNAM Instituto de Investigaciones Históricas, 1967 (2 vols.)
} 
El tabaco tuvo en la sociedad hispana y novohispana una acogida contundente, al ser exportada a España y Portugal estos países desarrollaban investigaciones al respecto: hicieron la caracterización botánica del tabaco y surgieron en muchos países dibujos y grabados abordando desde el descubrimiento de América hasta el siglo XVIII. A esta planta se le dieron en el mundo, diversos nombres, Jean Nicot quien era embajador de Catalina de Médicis en Portugal envió tabaco a Francia en 1561 en donde el prior Francisco de Lorena difundió su uso, por estos tres personajes se le llamó: hierba de la reina, hierba del prior y nicotina.

\subsection{EL TABACO EN MÉXICO DURANTE EL SIGLO XVIII Y LA PRIMERA MITAD DEL SIGLO XIX.}

Durante el esplendor barroco, los excesos eran la norma de todo, en la religiosidad, el arte, las fórmulas de relación social, etc. en México para los novo hispanos fumar no era considerado ni vicio, ni exceso, pero los recién llegados al continente percibían de modo distinto esta costumbre.

Fray Francisco Ajofrín se refirió a los mexicanos de la siguiente manera:

"Son muy dulces y cariñosos en su trato. El modo de saludarse cuando se encuentran, es afabilísimo y para la gravedad europea muy extraño. Aún cuando sea hombre con mujer se dicen: adiós, mi alma; adiós, mi vida; adiós mi consuelo[ .... ]

Pero en cuanto al tabaco señala:

"El tabaco de hoja es puro abuso de la América. La fuman todos, hombres y mujeres; hasta
las señoritas más delicadas y melindrosas; y éstas se encuentran en la calle, a pie o en coche
con manto de puntas, y tomando su cigarro; y como en España traen el reloj colgando de la
basquiña, aquí traen su cigarrera de plata o de oro y aún guarnecida con diamantes. La figura
de la cigarrera es como un botecito pequeño de cuatro a cinco dedos de alto, y cuelga de una
cadenita. En las visitas de las señoras pasan varias veces una bandeja de plata con cigarros y
un braserito (y los he visto muy pulidas) de plata o de oro con lumbre" 
"Fuera de casa no se desdeñan ni señoras ni señores de sacar el eslabón y yesca para tomar el cigarro aunque estén delante de personas de mayor respeto....Los religiosos y clérigos se encuentran también en las calles tomando cigarro, habituándose desde niños a este vicio, y creo que lo aprenden de las amas de leche, que aquí llaman chichiquas y regularmente son mulatas o negras. $Y$ como esta viciosa costumbre se ve autorizada con las personas de primer carácter, se comunica fácilmente a los que pasan de Europa, siendo su consumo exorbitante, pues apenas dejan el cigarro de la mano todo el día excepto el tiempo que están en la iglesia, cuyo lugar está exento de este vicio, pero no las sacristías" 57

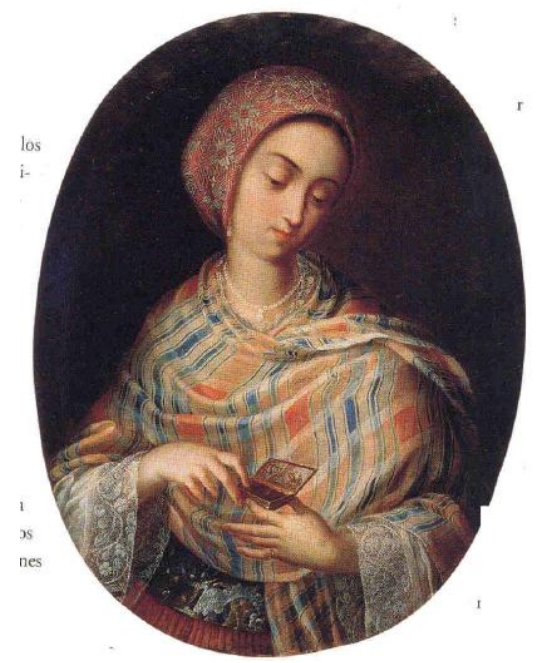

Figura73 Anónimo. "Dama con caja de rapé" Mediados del siglo XVIII. Óleo sobre tela 83X63 cm (oval) Col. Museo Nacional de Historia.

En efecto, tener disponible el tabaco en cualquier momento, hizo frecuente el uso de cigarreras y cajas de polvos, de cuyo valor y forma encontramos datos en los inventarios de dotes o herencias, un ejemplo es el de Don Antonio Rodríguez de Pedroso quien en 1784, después de enviudar el mismo año fue ordenado sacerdote e hizo que se practicara un inventario y avalúo de todos sus bienes que dio en herencia, casi en su totalidad, a su hija mayor Doña María Josefa, condesa de Xala y de Regla, entre estos objetos y refiriéndonos al tabaco encontramos:

\footnotetext{
${ }^{57}$ Francisco de Ajofrín Fr, Diario de Viaje que hizo a la América en el siglo XVIII el P. Fray Francisco de Ajofrín. México, Instituto Cultural Hispano Mexicano, México, 1964, pp 60 y 78
} 
"Una caxa de polvos de oro y Esmalte azul de particular hechura, guarnecida de chispas de diamantes y Rubíes y en la tapa un Obalo, pintadas en miniatura dos figuras; en doscientos ps"

"Dos braceritos de mesa, quintados, con peso de cinco marcos, quatro y media onzas, á ocho pesos, quatro reales marco; impta, quarenta y siete pesos, dos rs (reales) y una quartilla"58

\subsection{EL ESTANCO DEL TABACO}

El 13 de agosto de 1764 el visitador José de Gálvez estableció el estanco del tabaco, y en 1776 fue creada la administración de la Renta del Tabaco para reglamentar y supervisar su siembra, elaboración y comercialización. Se dividió en administraciones generales o factorías: Guadalajara, Valladolid, Durango, Rosario, Puebla, Veracruz, Oaxaca, Orizaba, Córdoba y Mérida; administraciones independientes: Monterrey, Coahuila, Nuevo Santander y Mayapil; administraciones foráneas del Arzobispado de México, y estancos del casco de la ciudad de México. Sus atribuciones fueron: supervisar y dar cuenta a la Real Hacienda sobre el funcionamiento de la renta y remitir a España los informes respectivos; reglamentar, contabilizar y comprobar las cuentas y razones de la renta; expedir las certificaciones de liquidaciones; registrar y controlar la entrada y salida del tabaco de los almacenes generales; resguardar la renta del tabaco; evitar cultivos prohibidos y contrabando; supervisar el trabajo de los empleados e inspeccionar las condiciones materiales donde laboraban; instalar fábricas de puros y cigarros; controlar la producción, distribución y venta de puros y cigarros.

\footnotetext{
${ }^{58}$ Manuel Romero de Terreros. Una casa del siglo XVIII en México. La del Conde de San Bartolomé Xala. Estudios y Fuentes del Arte en México, vol VIII, México, UNAM IIE, 1957, pp 8 y 34
} 
Las factorías tenían las siguientes funciones: contratar a los labradores para asegurar la siembra; distribuir y vender el tabaco; administrar y resguardar los productos de la venta y, finalmente, la manufactura de puros y cigarros. Presentamos un dibujo de la planta de la fábrica de cigarros de Manuel Conique en Guadalajara.

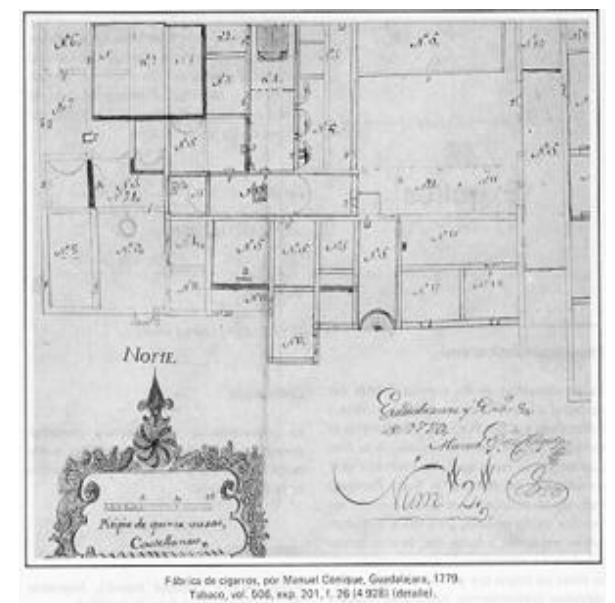

Figura 74 Fábrica de cigarros, por Manuel Conique, Guadalajara, 1779. AGN 201, f. 26, (4928) (detalle).

Juan de Viera ${ }^{59}$ consideró que la fábrica de cigarros era una construcción muy importante por su extensión y la cantidad de operarios que en ella trabajaban, evoca la forma en que se separaban las mujeres de los hombres para conservar las "buenas costumbres" de la época:

\footnotetext{
"Tantos son los operarios, así de hombres como de mujeres, que ocurren a trabajar a ésta fábrica, habiendo en ella una extensión imponderable para tanto individuo, estando separadas las oficinas de los hombres y las mujeres; habiendo para esto, en unas y otras oficinas, maestros y maestras que celan y cuidan que transite hombre a la oficina de mujeres, ni mujeres a la oficina de hombres, teniendo puertas separadas, así unos como toros, para entrar y salir sin mezclarse los unos con los otros"
}

\footnotetext{
59 Juan del Viera, Breve y Compendiosa narración de la ciudad de México (1977-78) México, Instituto José María Luis Mora, Primera edición facsimilar, 1992. p 92

${ }^{60}$ Juan de Viera nació en Puebla obtuvo el grado de Bachiller en la Real y Pontificia Universidad. Gracias al Virrey Bucareli fue administrador del Colegio de San Ildefonso.
} 
Pero no importaba la separación de operarios y operarias, el estanco del tabaco produjo alboroto y sublevaciones, fue el ramo principal de la Real Hacienda destinados a España y su valor líquido anual era de tres y medio millones de pesos. Por cierto, este estanco significaba restricciones en su cultivo, elaboración y comercio, por lo que los cultivadores privilegiados, tenían que vender su cosecha al gobierno al precio que éste les fijara, lo mismo sucedía con la fábrica que se situaba en la actual Ciudadela en la que se empleaban 17 256 personas. Podemos asegurar que fue la renta más productiva y un monopolio absurdo: En 1795 el valor de la producción fue de $161,859,400$ pesos.

En 1802 hizo su aparición en México un diccionario feyjoniano en el que se abordó el tema del tabaco, su autor escribió lo siguiente:

"Tiene sonido de paradoxa lo que voy a decir del chocolate, vino y tabaco y es que
conservan la vida quitándoles la respiración y la pierden dexándoles respirar.
Sufocados viven, y alentados mueren. Aquello que exhalan, y con que se hacen
sentir en el órgano del olfato, es su parte estrepitosa: luego cuanto más respiran
más espíritu pierden"61

Alejandro de Humboldt viajó a Nueva España de marzo del 1803 a enero de 1804 y por supuesto abordó el tema del tabaco. Opinaba que sería un ramo muy importante de la agricultura y economía mexicana si su comercio fuera libre, pero con el estanco real su precio y cultivo se limitaron. Observó que los guardas de

\footnotetext{
${ }^{61}$ Antonio Marqués y Espejo. Diccionario Feyjoniano o compendio metódico de varios conocimientos, críticos, eruditos y curiosos, utilísimo al pueblo para quien le dispuso el Doctor Don Antonio Marqués y Espejo, Presbítero pensionado por S.M. Capellán Colector de la Real Casa de Recogidas de esta Corte tomo I Año MDCCCII
} 
tabaco recorrían el país para arrancar las plantas que se encontraban fuera de los distritos autorizados y multar a aquéllos que se atrevían a cultivarla para autoconsumo, anotaba que la reducción en el cultivo perjudicaba de manera importante a las regiones que habían suspendido su producción: Guadalajara Autlán, Ezatlán, Ahuxcarlán, Tepic, Acaponeta y otros:

\footnotetext{
"Este consumo de tabaco en Nueva España debe parecer enorme, mayormente si se considera que sobre una población de 5, 800, 000 almas se deben descontar dos millones y medio de indígenas que no fuman. De otra parte de Mégico la venta del tabaco es un objeto mucho más importante para el fisco que en el Perú, porque en el primero de aquellos dos países, el numero de blancos en mucho más considerables y el uso de fumar mucho más común, aun entre las mugeres y niños"62
}

En la piedra litográfica (Fig. 75) podemos observar el escudo nacional mexicano utilizado en diversas presentaciones de puros, pero es interesante la leyenda en torno al escudo; abordaremos primero la imagen del águila y la serpiente:

Las organizaciones primitivas que un poco más tarde estarían agrupados por estados crearon mitos para legitimar la posesión de los territorios ocupados y elaboraron símbolos que las representarían, entonces daban cuenta del origen de la nación.

Este mito de la creación del cosmos narraba la aparición de la primera Montaña Verdadera, que había brotado de las aguas primordiales y contenía en su interior el agua fertilizadora y las semillas nutricias que sustentarían a los primeros seres humanos. Esto aludió a la fertilidad y al origen de la vida.

Al norte de Tenochtitlan es parte de la vegetación un tipo de cactus que los mexicas eligieron como árbol emblemático: el nopal y otros

\footnotetext{
${ }^{62}$ Alejandro de Humboldt. Ensayo Político sobre el Reino de la Nueva España 2 París, 1822 p 400 .
} 
símbolos de identidad mexica relataba su peregrinación desde el remoto Aztlán hasta la fundación de Tenochtitlan en 1325.

Según este mito, el dios de la tribu era Hiutzilopochtli quien les ordenó abandonar Aztlán y buscar mejores tierras en donde encontrarían: un águila agitando sus alas, parada sobre un nopal y desgarrando una serpiente.

Uno de los jeroglíficos de ese símbolo era la piedra que brota del nopal, interpretación del corazón de Copil, era hijo de Malinalxóchitl la hermana del dios tutelar mexica: Hizilopochtli. Malinalxochilt tuvo un conflicto con su hermano y fue apartada de la tribu, cayó en desgracia; pero buscó refugio en Malinalco, en donde procreó a Copil, inculcándole odio hacia Hizilopochtli. Mucho tiempo después los mexicas se asentaron en Chapultepec y fueron hostigados por los pueblos vecinos. Copil aprovechó la ocasión para sublevar a los pobladores de la cuenca contra la tribu de recién llegados, luego subió a una colina para contemplar la destrucción de sus enemigos comandados por Huitzilopochtli. Pero como Hitzilopochtli tenía el don de la clarividencia se anticipó a las intrigas de su sobrino y con sus capitanes capturó a Copil lo decapitó, le arrancó el corazón y se lo entregó a uno de sus sacerdotes quien lo arrojó al centro de la laguna en donde se convirtió en piedra de la que surgió un nopal este árbol emblemático tiene un lugar destacado en la iconografía sacrificial de los mexicas pues representa el corazón humano. Los corazones de los cautivos sacrificados eran llamados quehunochtli tlazoti las preciosas tunas en las que se posaba el águila.

Por otra parte, el águila es la representación del sol y al estar devorando la serpiente alude a la victoria del sol sobre sus enemigos, expresando el triunfo de los guerreros sobre los antiguos pueblos 
agrícolas. Así el águila real o dorada aparece en los emblemas y escudos mexicas y hace alusión a la fuerza violenta en tanto que la serpiente fue considerada un símbolo de fertilidad.

Los conquistadores españoles, fundaron la ciudad sobre los escombros de Tenochtilan, luego le dieron un nombre más sonoro México. Al reino lo llamaron Nueva España, y es así que se hizo la representación del águila parada en un nopal devorando una serpiente, esculpidos en piedra en los conventos, en casi todos los templos, monasterios y monumentos civiles durante el siglo XVI, a pesar de que trataron de introducir un nuevo emblema.

La difusión del antiguo emblema mexicano se generalizó durante el siglo XVIII entonces muchas ciudades se habían transformado en núcleos mestizos que en su búsqueda de identidad rechazaron los símbolos del poder español y se identificaron con los símbolos mexicas.

Entre 1701 y 1721 en los grabados y monedas que conmemoraban los hechos importantes del virreinato o de la ciudad, se conservó el escudo oficial con el castillo y los dos leones arañando sus paredes, pero entre 1724 y 1747 se volvió a timbrar el escudo de ascendencia hispánica con el águila parada en el nopal.

De tal forma que la progresiva penetración del escudo mexica en el imaginario colectivo y en diversos instituciones hizo que la iglesia de donde había sido expulsado como símbolo de idolatría, lo aceptara incorporándolo en las portadas de la catedral de Morelia y la Catedral Metropolitana desde entonces aparece en los remates de portadas de iglesias, retablos, en pinturas, en sombreros y estandartes, en planos, libros, monedas, etc. 
En cuanto a la creación de la bandera y escudo nacionales, después de la guerra de independencia (1811) se esbozó la primera forma de gobierno revolucionario y el 19 de agosto de ese año se acordó la elección de un escudo para actas, proclamas y documentos oficiales. El escudo recoge la imagen del águila parada sobre el nopal y le agrega banderas, cañones, es decir, el estruendo de la guerra. José María Morelos por primera vez colocó el emblema en una bandera insurgente. El águila de Morelos es la misma que la de la Junta de Zitácuaro: un águila de frente con las alas extendidas mirando hacia su derecha parada sobre un nopal. La declaración de independencia suscitó júbilo y festejos y favoreció la producción de incontables arcos triunfales, carros alegóricos, pinturas alegorías, obeliscos etc. (fig. 76)

Se representaba a la patria rompiendo sus cadenas, sus héroes y emblemas y el águila mexicana que remonta el vuelo liberada de sus antiguas ataduras En la Constitución de 1824 se observa el águila sin corona combatiendo con la serpiente, parada sobre el nopal heráldico, brota de un montículo que emerge de la laguna. Una de las características más notables del emblema mexicano es el predominio de los símbolos antiguos sobre los recientes, su explicación se basa en que el emblema indígena comunicó a diversos grupos la imagen del pasado, que contenía nociones de su origen, parentesco, grandeza, vitalidad, legitimidad y prestigio y es un importante signo de identidad, En el siglo XIX se imprimía en gacetas, cartas geográficas, revistas, pintura, grabado, arquitectura, etiquetas de cigarros y puros para denotar que es propio de México. 


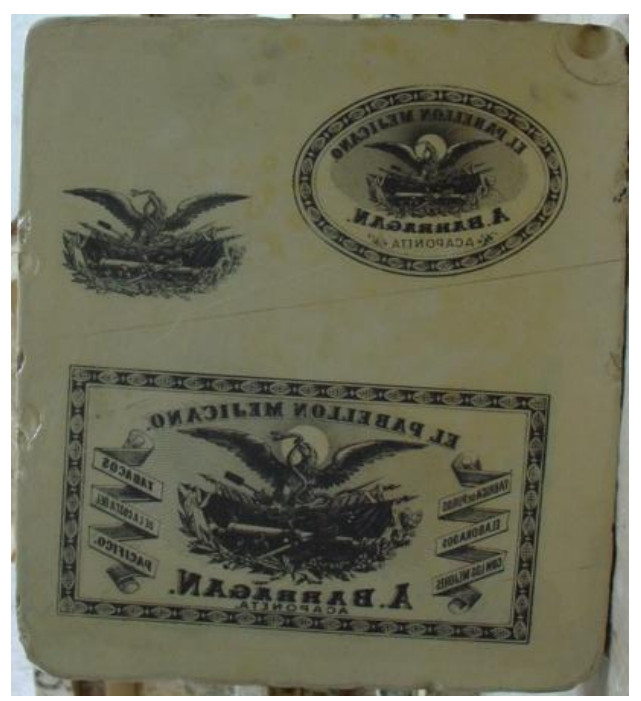

Figura 75 Piedra litográfica. Academia de San Carlos de México. Marca: El Pabellón Mexicano. A Barragán . Etiqueta para caja de puros.

Imp $^{\circ}$ L. Mayagoitia. Academia de San Carlos de México. 2003

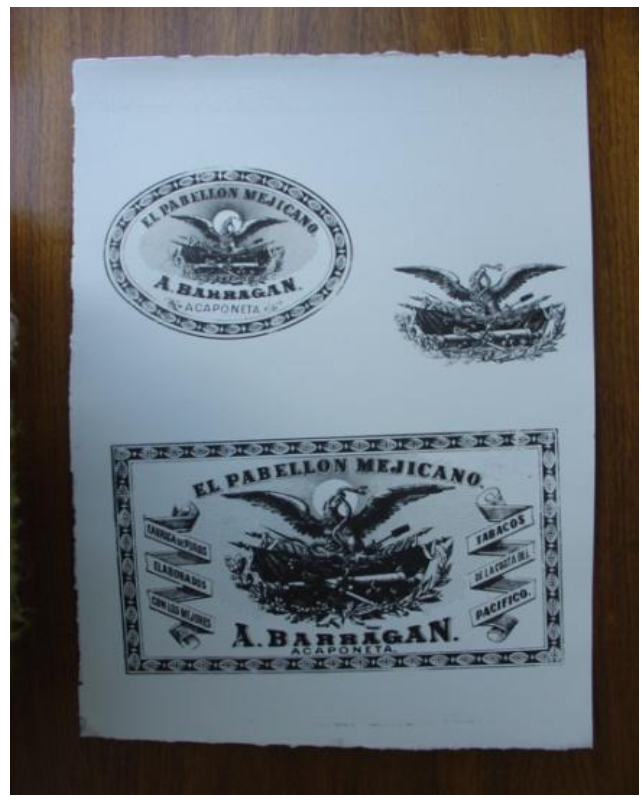

Figura76 Academia de San Carlos de México. Marca: "El Pabellón Mexicano".

A Barragán Etiqueta para caja de puros. Imp. L. Mayagoitia. 2003 Imprimió L. Mayagoitia. Academia de San Carlos de México.

Las arcas de la nación mexicana estaban totalmente vacías debido a la prolongada guerra de independencia y las medidas tributarias, el gobierno se enfrentó al problema de la hacienda pública, en el 
Congreso Constituyente el 24 de febrero de 1822, la Comisión de Hacienda observó que el estanco del tabaco había sido poderoso durante la colonia y sugirió que podía servir al gobierno independiente, imponiendo un impuesto a la libre siembra y venta del tabaco, argumentando que este producto no era de primera necesidad, pero Agustín de Iturbide ya en solio imperial, el 21 de mayo de 1822, no aprobó el decreto porque consideraba que para sus tropas si era necesario, aún así expidió un decreto en el que el estanco del tabaco continuaría por dos años, plazo que no se cumplió porque Iturbide abdicó el 19 de marzo de 1823.

A partir de este hecho, la Comisión de Hacienda presidida por Joaquín Obregón, Bernardo José Benítez, Rafael Pérez del Castillo, Francisco Manuel Sánchez Tagle y otros, presentaron un estudio en los que se indicaban los efectos sociales del estanco, apuntaban que había sido ruinoso para la moral pública, porque al establecerlo fue necesario contratar a guardias que se ocupaban de perseguir y oprimir al infeliz, a la viuda, a la huérfana que para ganarse un mendrugo ocultaban un manojo de tabaco o fabricaban dos o tres cajetillas de cigarros. Para que los guardias hicieran su trabajo, había sido preciso autorizar, fomentar y estimular el espionaje.

En 1824 en la República, primero federal y luego centralista en 1835, se inició la polémica en torno a la industria del tabaco: Una opción fue conservar el estanco de manera tradicional y la otra quitarlo. Guadalupe Victoria, presidente de los Estados Unidos Mexicanos, expidió un decreto el 23 de noviembre de 1824, declarando subsistente, por cuenta de la Federación la Fábrica de 
Puros, Cigarros y Polvo de la Ciudad de México y proceder a su consumo en la capital y otros territorios de la Federación. Dejaba en libertad a los estados para decidir sobre el asunto que dejaron en manos de particulares la fabricación y comercialización de cigarros y puros manufacturados.

En otros estados como Guanajuato la explotación (manufacturera y comercialización) quedó a favor de accionistas particulares que por medio de una renta, pagadera al erario estatal gozaban de exclusividad en esas actividades. Surgieron diversas marcas de cigarros como: "El Conquistador", "El Artesano", "El Rey del Mundo", "La Lotería" etc.

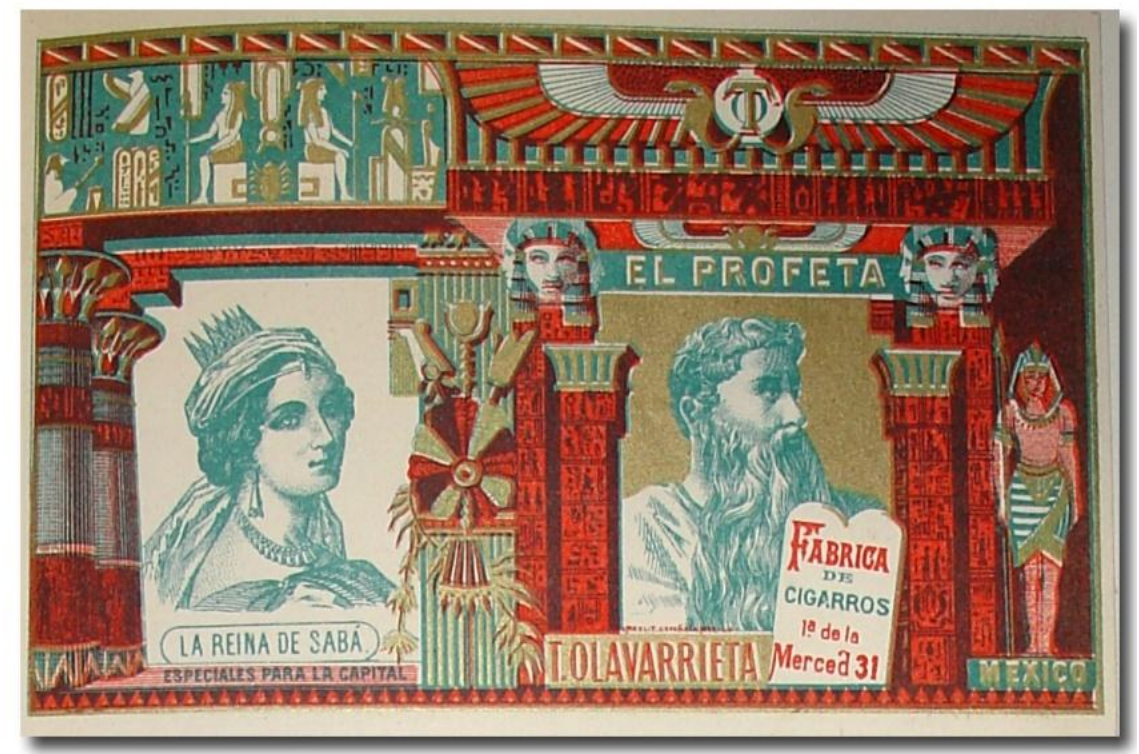

Figura 77 Marca: El Profeta. Fábrica de cigarros de T. Olavarrieta. Merced 31 1885. Litografía Española 


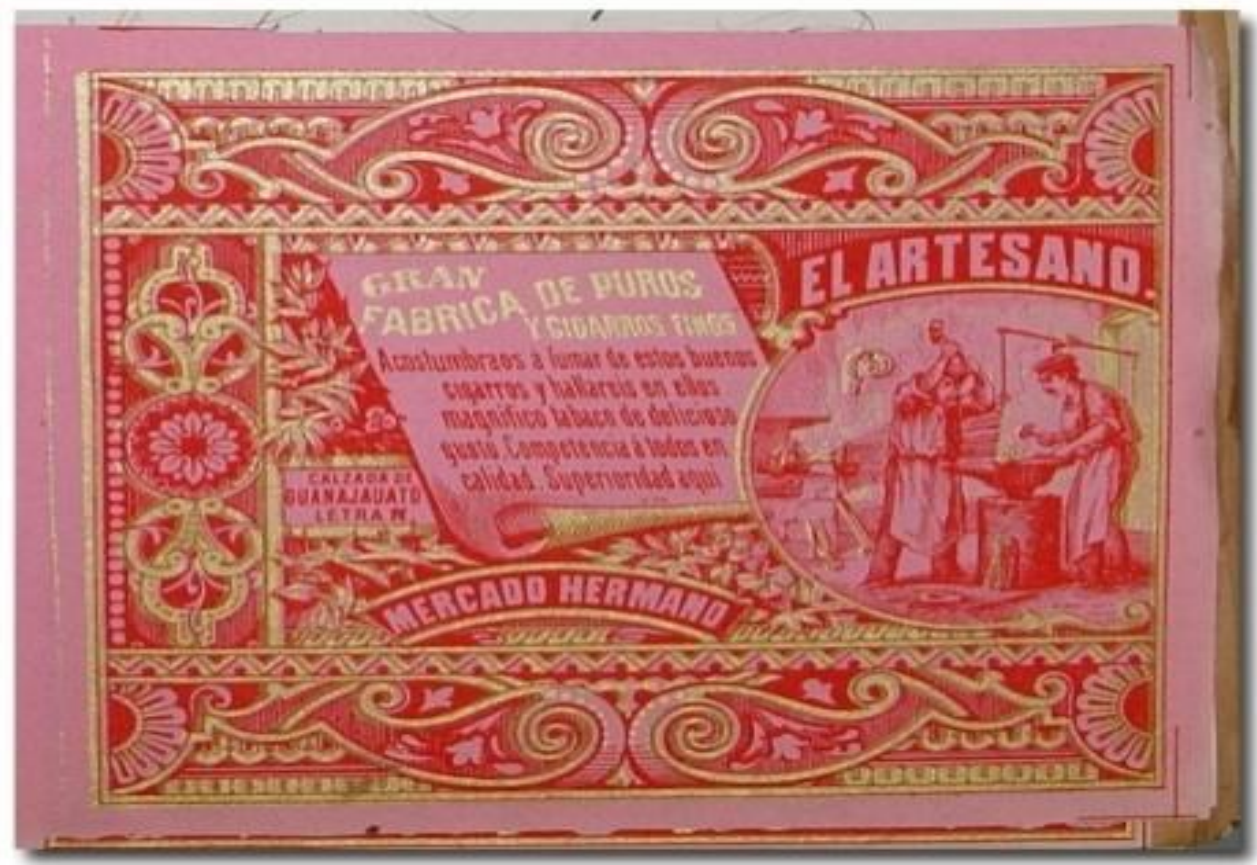

Figura 78 Marca: "El artesano" Fábrica de Mercado Hermano Abril 14, 1886. Lit. Debray y Sucs.

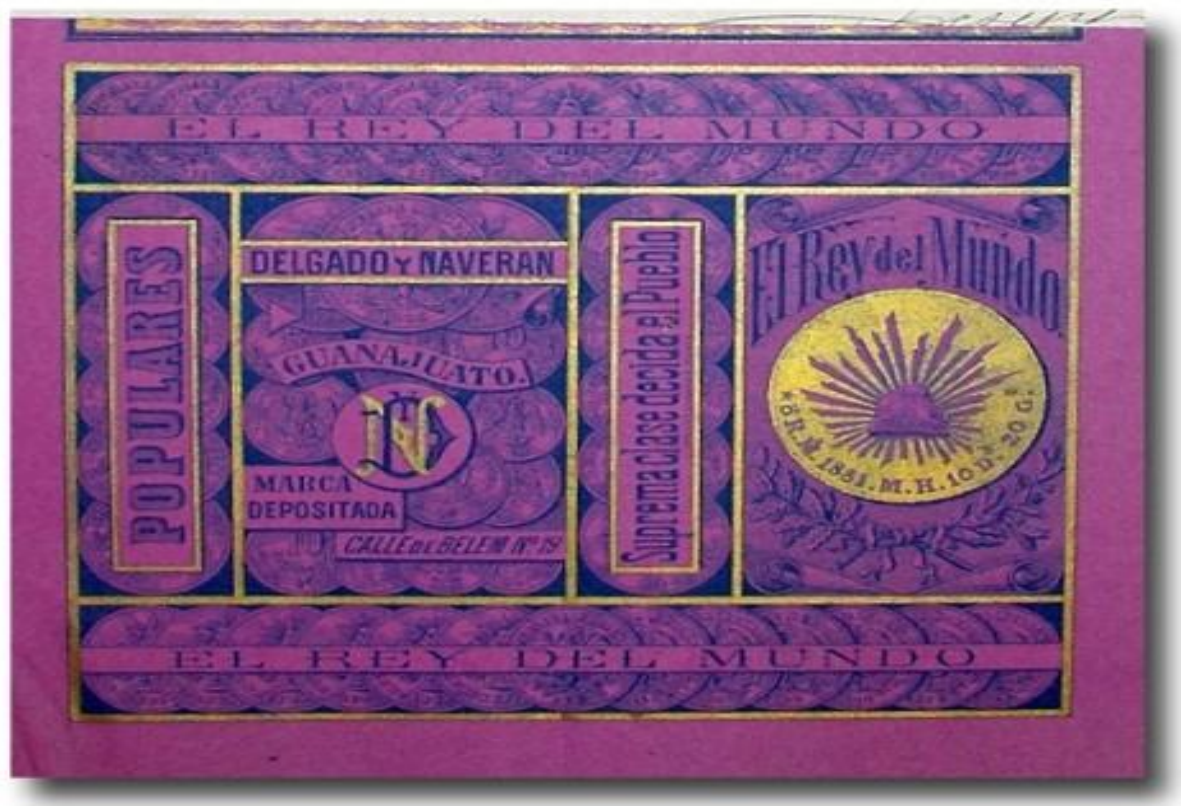

Figura 79 "El Rey del Mundo" Fábrica de Delgado y Naverán.

Reg. Propiedad a favor de Gregorio Palacio y Cía. Marca Depositada: 1886 


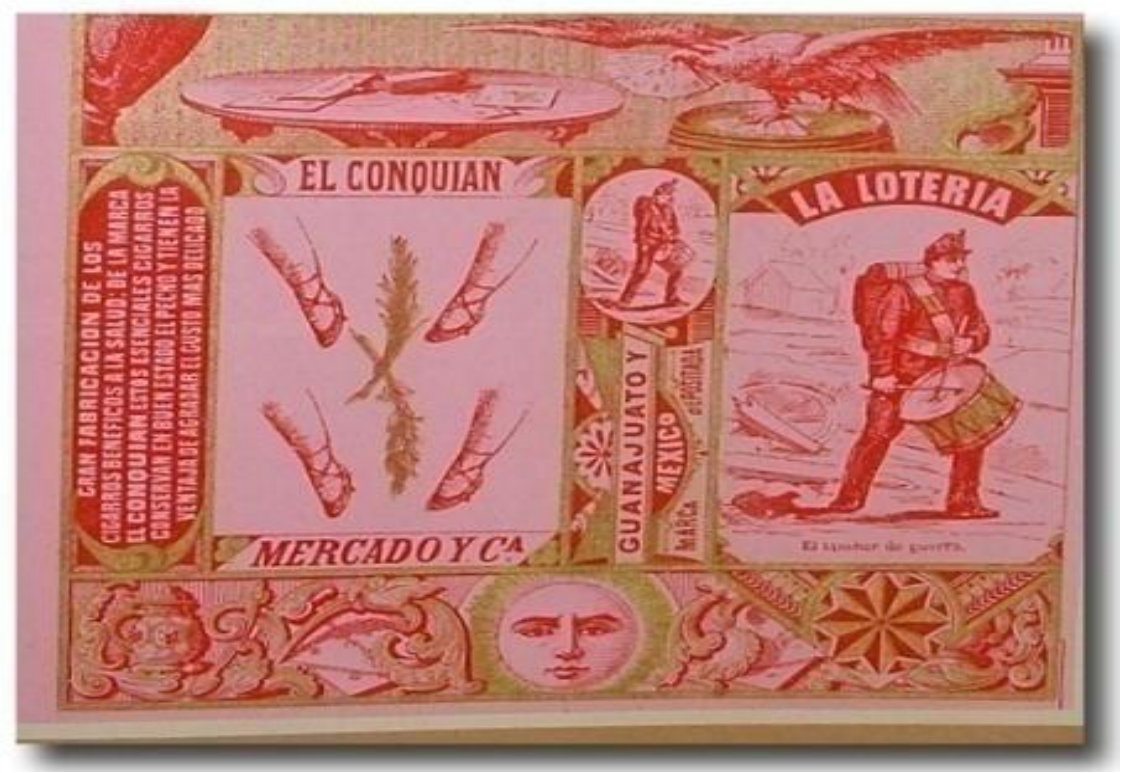

Figura 80 Marca: "La lotería" Registro de propiedad artística de Tomás Mercado. 19 Nov, 1886

Algunos estados se negaron a asumir la responsabilidad de conservar la renta del tabaco, conformándose con imponer impuestos a los tabacos que se introdujeran, la producción excedió con mucho a la demanda así que los cosecheros presionaron al gobierno federal para que los estados asumieran la renta del producto, en 1825 algunos estados de la federación empezaron a legislar sobre la renta del tabaco: Querétaro el 23 de febrero de 1825, Jalisco emitió un reglamento para la Administración General y la Renta el Tabaco, etc.

Aprovechando en 1833 la estancia de un gobierno conservador se lanzó un decreto y se abolió la renta del tabaco (a excepción de algunos estados que lo conservaron en sus rentas) se declaró libre y legal su comercio y el estanco fue sustituido por un impuesto de tres reales por cada 100 matas sembradas y de un real 
por cada libra de tabaco en rama, cernido o labrado. Pero surgió otro problema, el impuesto era incobrable, la evasión no se podía controlar debido a la inestabilidad política. Las arcas del gobierno permanecían vacías así que Lucas Alamán se reunió con un grupo de cosecheros y se formó la Sociedad de los Seis Departamentos, pretendía tomar en arrendamiento el estanco del tabaco en México, Puebla, Veracruz, Oaxaca, Michoacán y Querétaro, esta sociedad alcanzó éxito en sus transacciones, al año siguiente, algunos empresarios de estados no productores contrataron con la sociedad de los seis departamentos, formándose otra con nuevos socios. Tenían como objetivos: rematar la renta del tabaco en todos los departamentos de la República para unirse con las empresas particulares de los estados; invertir en nuevas plantaciones; contratar de nuevo con los cosecheros, establecer nuevos resguardos, etc. se aproximaba a un sistema unitario o central que exigía la renta del tabaco para ser bien y uniformemente administrada.

En fin, la discusión sobre el estanco del tabaco permaneció hasta la invasión norteamericana, cuando de hecho abolió el estanco del tabaco y el decomiso de existencias, por tanto, las fuerzas invasoras y las nacionales vinieron a acabar con el monopolio estatal y con las existencias. Pero a quince días de haberse retirado el ejército norteamericano, fue lanzada una convocatoria en los principales diarios, anunciando que el gobierno estaba resuelto a celebrar una compañía para la administración de la renta del tabaco, llegaron los acreedores pero la heterogeneidad de sus créditos fueron causa de que este evento no tuviera resultados, y el último recurso fue tratar con los antiguos tenedores de bonos entre ellos algunas firmas inglesas: Manning y Mackintosh quienes 
asociados con algunos industriales mexicanos como Manuel Escandón, J. de la Fuente y Manuel Bringas, etc. celebraron un contrato formal de arrendamiento con el gobierno mexicano el 18 de agosto de 1848. Por este convenio los industriales se comprometían a proporcionar el capital necesario y encargarse de la administración: el gobierno declaraba privilegio exclusivo para las compañías: sembrar, labrar, expender e importar tabaco en toda la república. El gobierno federal recibiría el 15 de ventas excesivas y los estatales recibirían el $10 \%$ y había un contrato por cuatro años forzosos para ambas partes.

Hasta 1856 se declararon libres la siembra y manufactura del tabaco y al año siguiente el 5 de febrero de 1857 se aprobó la constitución liberal que ponía las bases jurídicas necesarias para regular las relaciones económicas del libre mercado. Después de la caída del imperio de Maximiliano y de la guerra de intervención la situación de las fábricas era la siguiente: En Custepeques, Chiapas operaba una fábrica de puros y cigarros de hojas de maíz; en la ciudad de México había ocho fábricas de tabacos labrados; en Veracruz se fundó la fábrica de cigarros de los hermanos Balsa. 


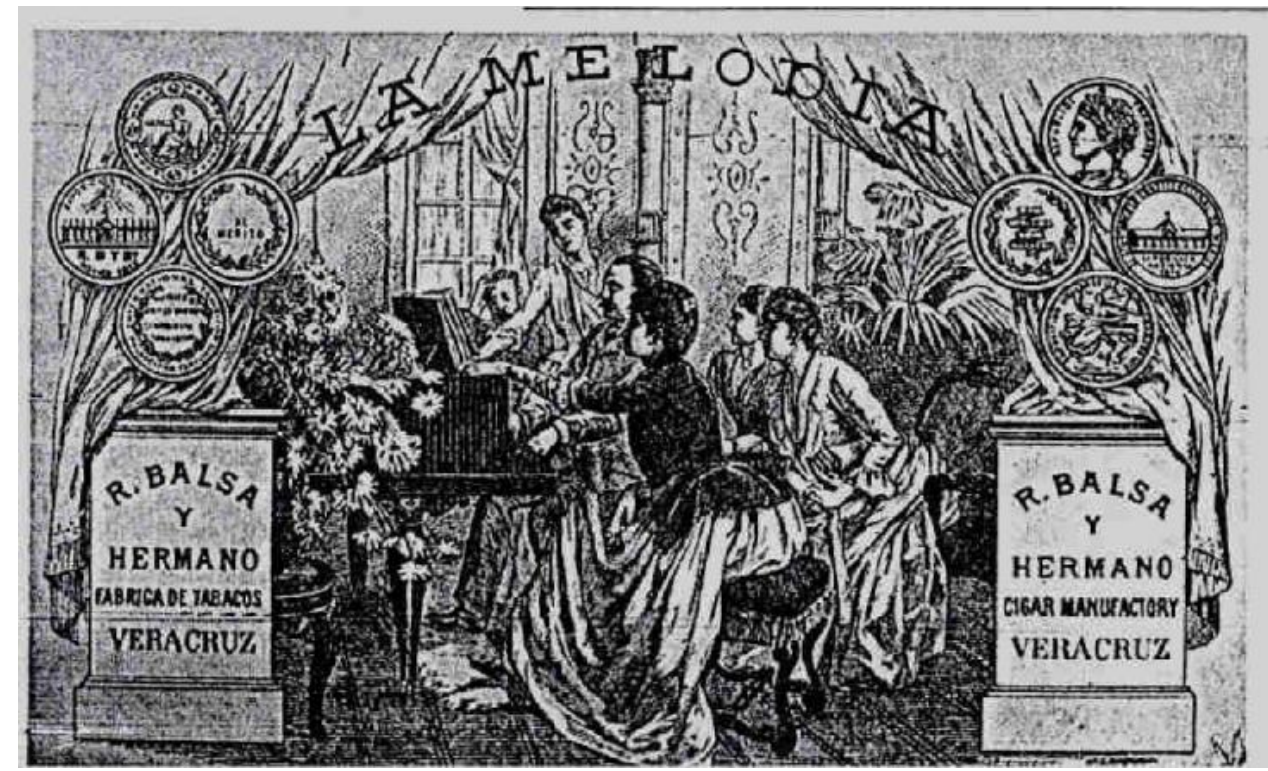

Figura 81 "La melodía" Litografía para las cajas de puros de Balsa Hermanos

\subsection{EL TRABAJO FEMENINO EN LAS FÁBRICAS.}

La administración de Rentas del Tabaco se dividió en 11 administraciones generales o factorías: México, Puebla, Oaxaca, Veracruz, Córdoba, Orizaba, Valladolid, Guadalajara, Rosario, Durango y Mérida. Cada una de estas administraciones generales estaba dividida en administraciones subalternas o administraciones de cabecera de partido, a las cuales estaban sujetos los fielatos y estanquillos.

Para 1837 en algunas factorías no solamente tabacaleras sino algodoneras se visualizaban las ventajas civiles, fabriles y domésticas que implicaría el trabajo femenino fuera del hogar, en este caso dentro de las fábricas de algodón: 
todas consumen del trabajo único productor, por consiguiente: el consumo debe ser más escaso y más contingente; en términos que el día que el único apoyo de la familia se inutiliza o se muere, comúnmente se vicia o perece toda ella"63

"Fácilmente en una misma fábrica, puede destinarse una familia entera, y de aquí se consigue que todos se conserven reunidos, lo cual importa para la moral de ellos: si el padre se extravía, la esposa u los hijos que todos tienen interés para cumplir bien en aquél lugar, y en quienes generalmente deben esperarse buenas costumbres por la ocupación útil y honesta lo contienen: y así relativamente los demás"64

"Hoy para una muger que quede viuda y pobre un solo hijo es una carga insoportable y esta sola viaja $v$ con su hijo y cuantos más tenga mejor, serán más felices y menos desgraciados si los dos secsos son admitidos en las fábricas modernas" ${ }^{\prime 65}$

“...pero reflexionen, que más peligro corre en su casa una muger joven ociosa y sola, por las separaciones que dos o res veces al día tengan que hacer sus mayores, o que ella tenga que salir, que en un lugar bajo la vista de sus deudos. Muy concurrido y muy cuidado por los directores y maestros que comúnmente han de ser personas de juicio, y por último un lugar donde nadie puede estar ocioso ni separarse de él porque las máquinas para andar bien sus operaciones progresivas, no permiten largas paradas ni distracciones"66

Durante la segunda mitad del siglo XIX, se dieron cambios en la producción de puros y cigarros, desde 1853 el Estado mexicano había liberado definitivamente el cultivo, comercio y manufactura del tabaco con lo que aparecieron pequeñas fábricas particulares junto a la Sociedad del Antiguo Estanco del Tabaco y los talleres artesanales llamados "Chinchalitos" abastecían las necesidades de la capital del país.

En 1855 Ignacio Ramírez escribió un artículo con gran sentido de humor con relación a la estanquillera, se refirió a su sociabilidad a su atuendo pobre pero elegante, su relación con enamorados y mujeres celosas de su belleza.

En la imagen que acompaña al texto litografía de Hesiquio Iriarte, observamos a una vendedora de cigarros y puros (fig.82), su

${ }^{63}$ Estevan Antuñano, Ventajas políticas civiles, fabriles y domésticas que por dar ocupación también a las mugeres en las fábricas de maquinaria moderna que están levantando en México, deben recibirse. Puebla, Oficina del Hospital de san Pedro, 1837 p. 3

${ }^{64}$ Ibid. p. 4

${ }^{65}$ Idem

${ }^{66}$ Idem 
comercio al menudeo, por sus rasgos y atuendo parece más española que mexicana. Apunta Ramírez:

“...la estanquillera sabe que Doña Rita fuma de a doce finos, y su esposo el banquero los acostumbra habanos; pero observa que por las noches, después de que entra un español de visita, una sirviente que no fuma, sale a comprar puros del país.....La estanquillera vende rapé; Doña Ambrosia se lo compraba, pero dejó el vicio atribuyendo al rapé una enfermedad que la privó de las narices, y regaló su caja a un compadre que después ha aparecido también desnarigado, ergo el mal no se encuentra en el polvo, sino en la caja de Da Ambrosia".... ${ }^{67}$

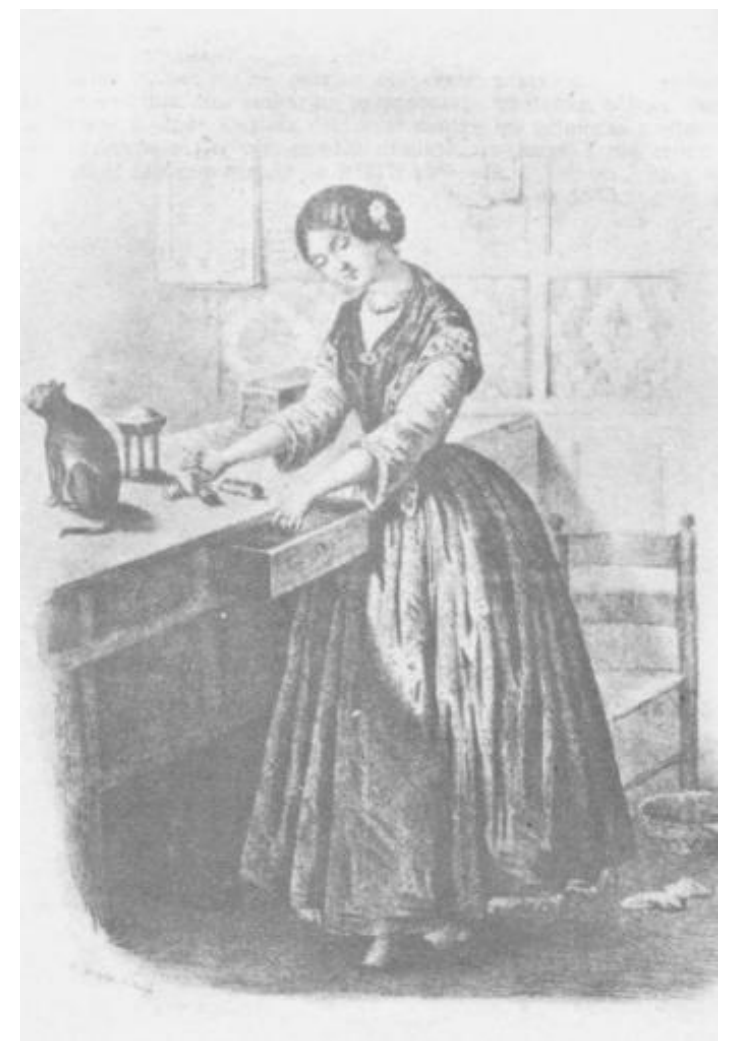

Figura 82 La Estanquillera. En: Los mexicanos pintados por sí mismos. Litografía

${ }^{67}$ Hesiquio Iriarte, Los mexicanos pintados por si mismos,_la edición original fue hecha en la casa de M. Murguía, Portal del Águila de Oro en 1855. México, Símbolo, 1946 
Como todavía desarrollaban procedimientos manuales, en las fábricas se empleaban hasta trescientas operarias por establecimiento, mismas que producían al día- cada una 2500 cigarros, su jornada de trabajo iba de las seis de la mañana a las siete de la noche.

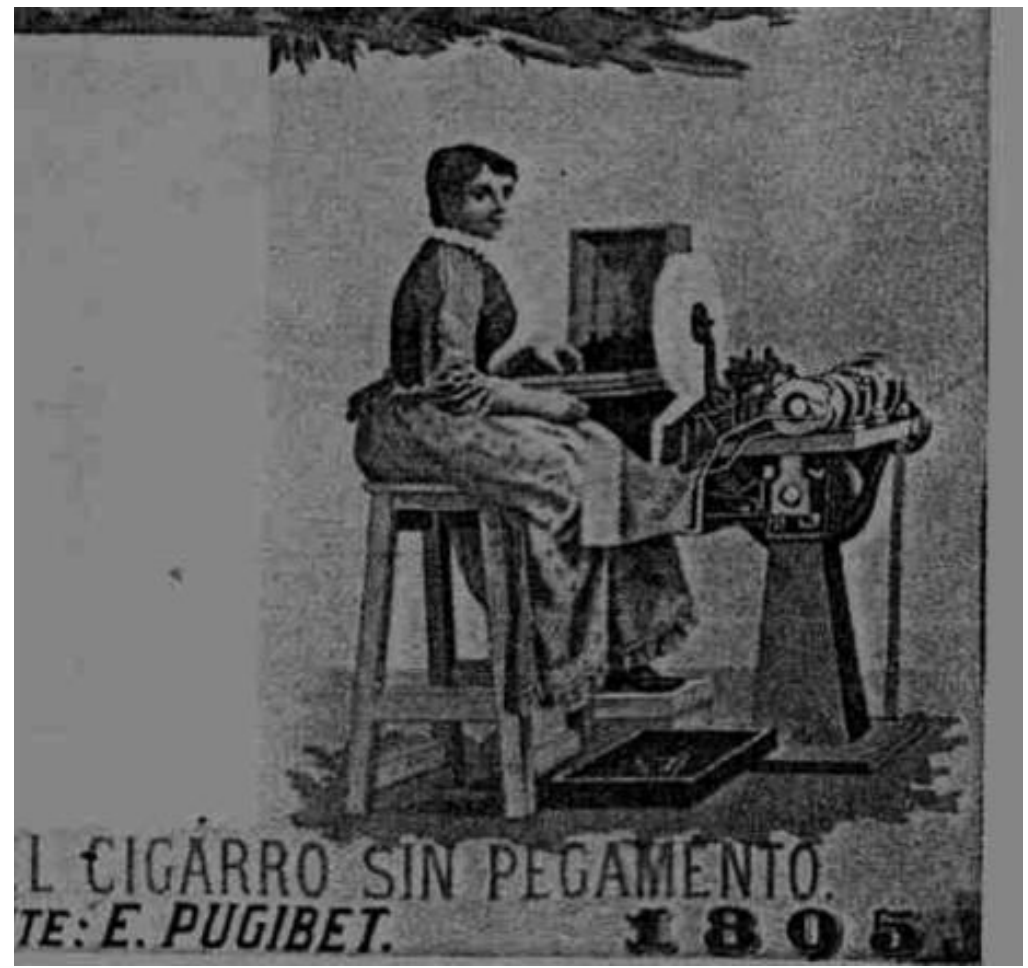

Figura83 Etiqueta de cigarros. E. Pugibet. 1805. Litografía.

La fábrica "El Buen Tono" pertenecía al industrial francés Ernesto Pugibet había dotado a la capital con una fábrica de tabacos labrados que competía con las más prestigiadas fábricas cubanas. En 1882 trajo al país una máquina para hacer cigarrillos de tipo francés, producía por minuto 192 cigarrillos sin requerir más atención de un operario francés y dos mujeres: una que preparaba el tabaco y otra que lo surtía a la preparadora. 
Con este nuevo tipo de trabajo industrializado el trabajador tenía que abandonar su domicilio para trasladarse a la fábrica, en la que vendería su fuerza de trabajo a cambio de un salario. Pero la industria del tabaco en México durante el siglo XIX se caracterizaba por reunir a un alto porcentaje de mujeres, que vivían en la urbe, eran asalariadas. Observamos dos vertientes: el surgimiento del proletariado moderno y la incorporación de la mujer, como obrera, en la actividad económica y en el mercado de trabajo con esto empezó la lucha entre los sexos por apropiarse de las fuentes de trabajo.

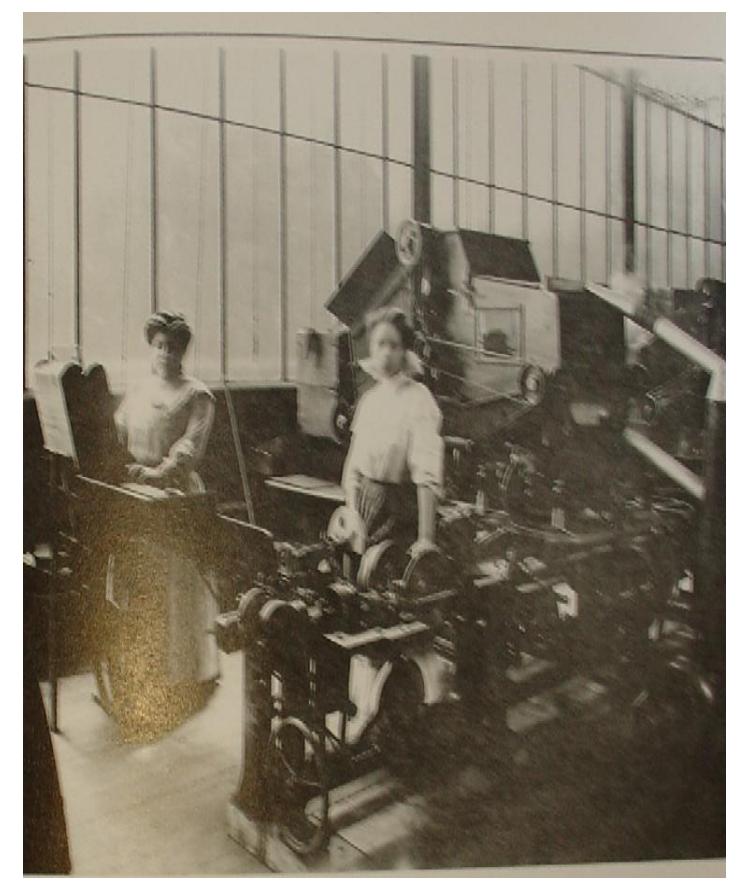

Figura 84 Trabajadoras del Buen Tono

A partir del trabajo femenino en las fábricas surgieron otros problemas, uno tenía que ver con el valor adquisitivo de la moneda 
de cobre con que les pagaban. ${ }^{68} \mathrm{Al}$ hacer ellas sus compras, los comerciantes aceptaban la moneda por la mitad de su valor, en 1837 se inició el "motín del cobre". Las operarias de la Fábrica de Puros y Cigarros de la Ciudad de México creyeron que con la nueva administración se iban a solucionar sus problemas y solicitaron que se les pagaran sus salarios en plata o en dobles piezas de cobre, así el 14 de diciembre de 1841 provocaron un motín resultando algunas heridas y otras golpeadas, esta era la primera lucha de obreras que se expresaban mediante el enfrentamiento físico.

Pasaron los años, en 1846 el negocio de tabaco era próspero, pero surgió el rumor de que las máquinas modernas sustituirían a los operarios contratados para la producción. Sorprendieron a las operarias de la fábrica cuando supieron que el Sr. Adorno uno de los administradores, había viajado comisionado por la empresa hacia Europa, para adquirir maquinaria suficiente y moderna y traerla a México. Las operarias hicieron una "representación" pidiendo al gobierno que no se realizara ese proyecto (en esa época de la industria del tabaco dependían 30000 familias) en su impugnación asentaban que no podía existir una máquina que regulara la cantidad de tabaco, que diera la presión conveniente mientras cuidaba el cernido, la humedad requerida, el grueso del papel y otras cualidades a las que ellas estaban acostumbradas. Pero la modernidad habría de llegar y la introducción de la nueva tecnología marcó un límite entre la producción artesanal y la mecanizada. Desafortunadamente

\footnotetext{
${ }^{68}$ Desde 1814 el Virrey Félix María Calleja había iniciado la acuñación de moneda de cobre para cubrir la escasez de moneda fraccionaria, pero en 1837 su acuñación fue tan grande que ascendió a 5000000 de pesos y como se acuñaba moneda falsa tan bien hecha como la oficial, esta se devaluó hasta el 50 por ciento.
} 
para esas mujeres la independencia de Texas y la guerra de invasión de Estados Unidos hicieron que se disiparan sus quejas.

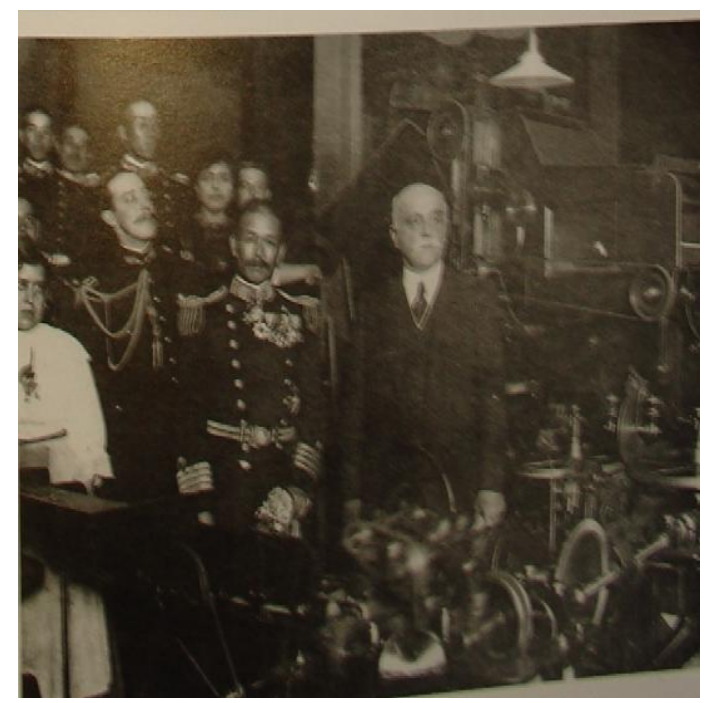

Figura 85 Ernesto Pugibet acompañado por marinos japoneses.

A partir de la segunda mitad de siglo XIX, México contó con un Estado liberal suficientemente estable y con varias empresas de capitalistas privados que entran en la libre competencia por el mercado del tabaco por tanto surgen muchos problemas obrero patronales.

En la fábrica La Bola los obreros se amotinaron declarándose en huelga, protestaban por que se intentaba enseñar a las mujeres labores que ellos desarrollaban ${ }^{69}$ cuestión que resultaba lógica para los patrones que pagaban siempre más barato el trabajo realizado por las mujeres y participaban menos en motines.

\footnotetext{
${ }^{69}$ Eduardo Pesqueira Olea. Historia y Cultura del Tabaco en México. México, Tabamex- Secretaria de Agricultura y Ganadería, 1985 p. 174
} 
Observamos en las etiquetas que el papel era de hojas de maíz y la fábrica de P. Munguía e hijos ubicada en la calle de La Merced No 8 en la ciudad de México (Figs. 86) presenta un paisaje y el puente del ferrocarril de "Paso del Macho".

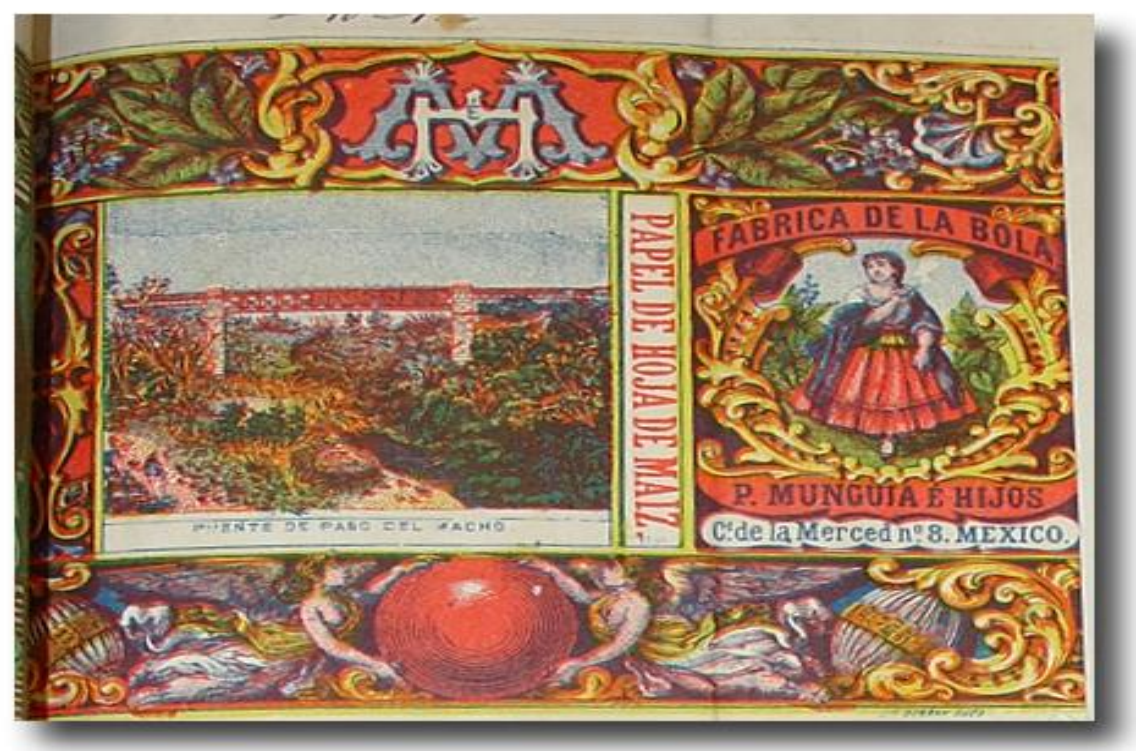

Figura 86 Fábrica de La Bola P. Munguía e Hijos. Papel de hoja de maíz. Cda. de la Merced No 3 México Etiqueta

De la misma fábrica la etiqueta de la figura,87 en la que presenta con ironía a unos "niños pequeños" vestidos con los uniformes de los soldados de los ejércitos francés ruso, recuerda irónicamente la Guerra de Crimea, dramático conflicto entre el Imperio Zarista y el Imperio Turco, apoyado por Francia e Inglaterra. Una guerra que frenó los deseos expansionistas de la Rusia Imperial hacia el Mediterráneo y Oriente Medio y que permitió sobrevivir al Imperio Turco. La Guerra de Crimea es también una guerra marcada por batallas sangrientas y por errores militares, como la famosa "Carga de la Brigada Ligera", durante la Batalla de Balaclava, quizás el más 
famoso error militar de la historia moderna. Pero, además de eso, es el culmen de la última cruzada que pretendió recuperar los Santos Lugares. En esta etiqueta a los soldados, se les denomina "los merodeadores, en Crimea" el soldadito del lado derecho tiene aparentemente un loro en la mano y el del centro hace un ademán como asintiendo ante las órdenes del franacés.

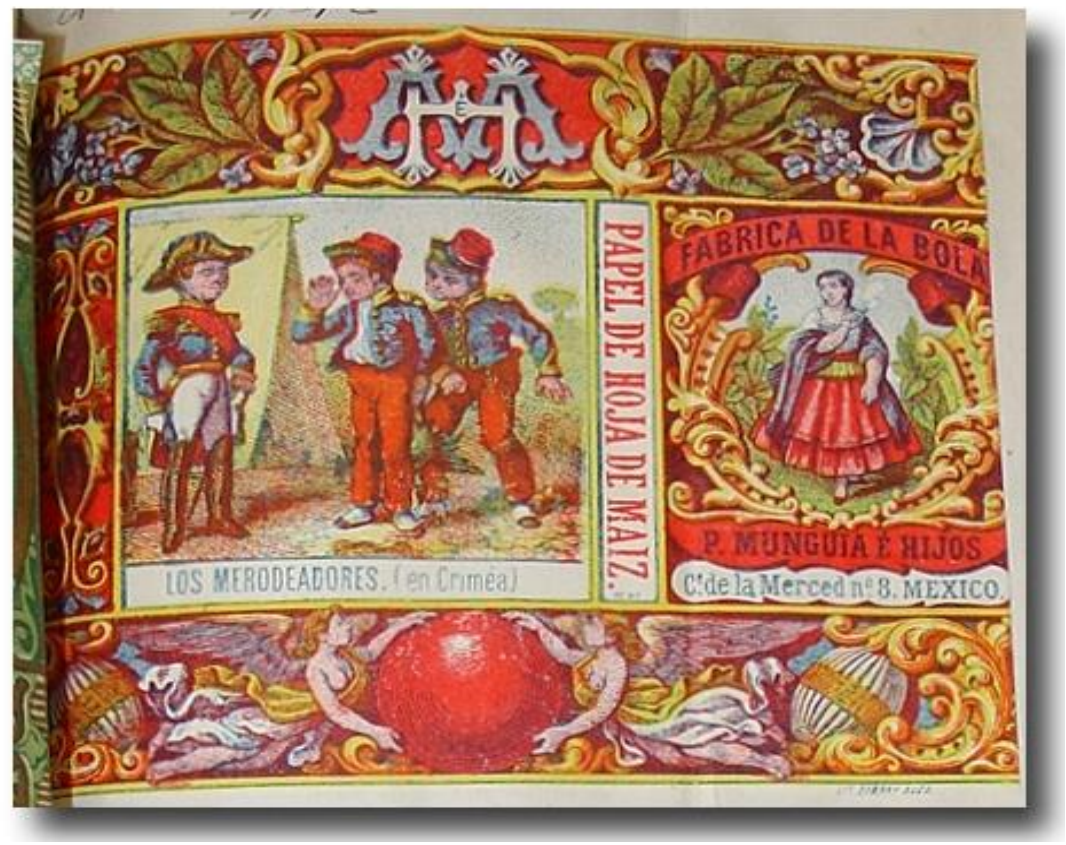

Figura 87 Fábrica de puros y cigarros La Bola sin rival.

Calle de la Merced No 3 Etiqueta

Unos años más tarde se registran también de la misma fábrica, las marcas "La Reina" y "El conquistador" en estas etiquetas observamos que la técnica litográfica ha avanzado, su factura es más exquisita en la propaganda dirigida a las señoras, recordamos que en México era común que las damas de todos los estratos sociales fumaran. 

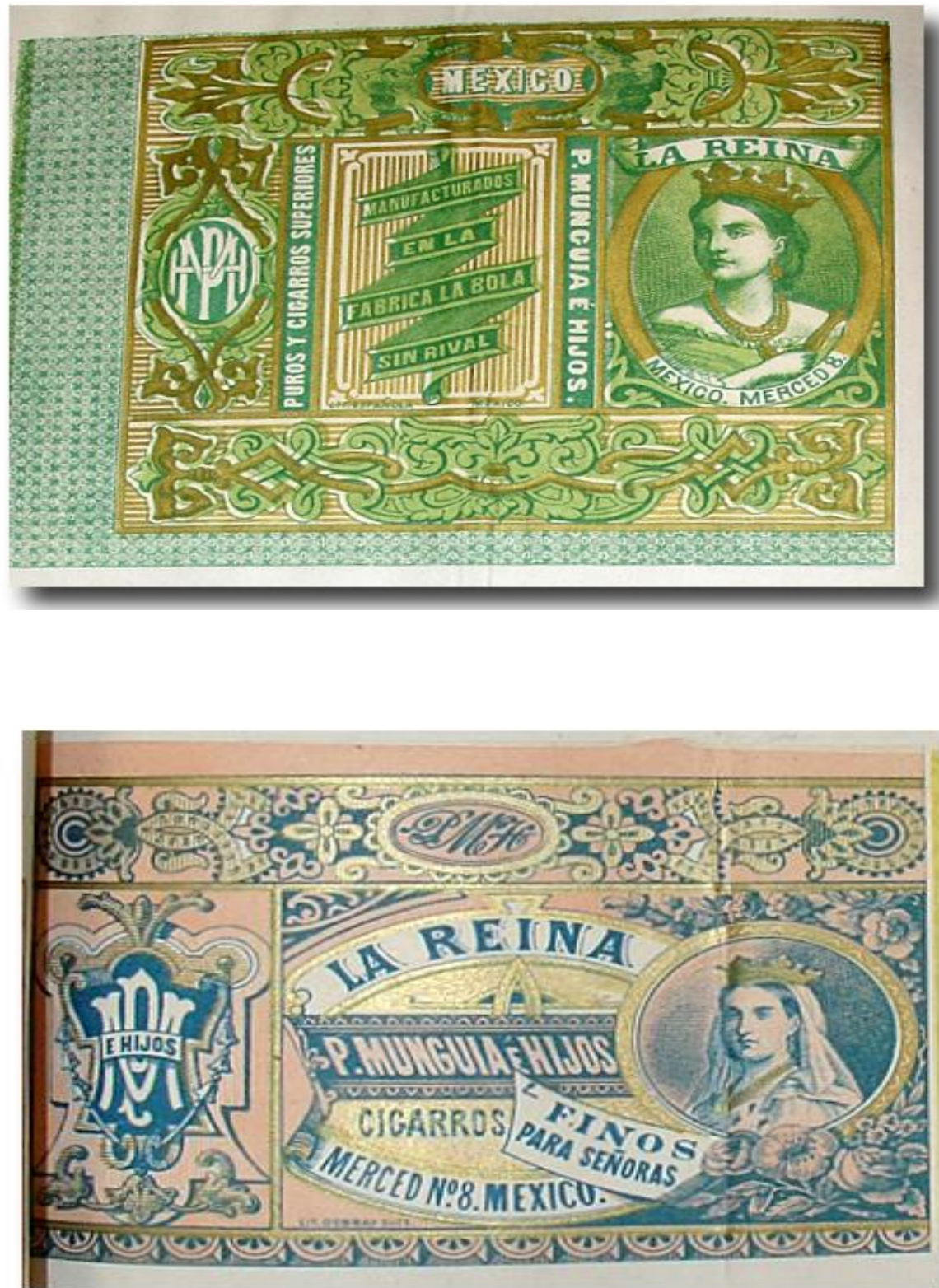

Figs 88 y 89 Marca: "La Reina"Cigarros finos para señoras. Fábrica de P. Munguía e Hijos. Merced 8 México. Manufacturados en la fábrica de La Bola Sin Rival 1884

Sin embargo, la mujeres eran consideradas descalificadas para participar en organizaciones mutualistas, por lo tanto, tuvieron que formar sus propias organizaciones y al verlas tan decididas 
fueron amenazadas con contratar "en vez de mujeres rijosas" varones encarcelados que obligados por la Comisión de cárceles y las condiciones peores que las obreras se ofrecían para trabajar a un precio menor que ellas. Las mujeres denunciaron los hechos ante la prensa pero los dueños de las fábricas estaban en libertad de contratar a quienes quisieran. Una de las huelgas de las trabajadoras duró veinte días pero vencidas por el hambre, renunciaron a su movimiento.

En 1877 estalló un movimiento de huelga que involucró a las trabajadoras de seis fábricas de cigarros de la ciudad de México: EI Negrito, La Sultana. El Modelo, La Africana, Los Aztecas y El Borrego.

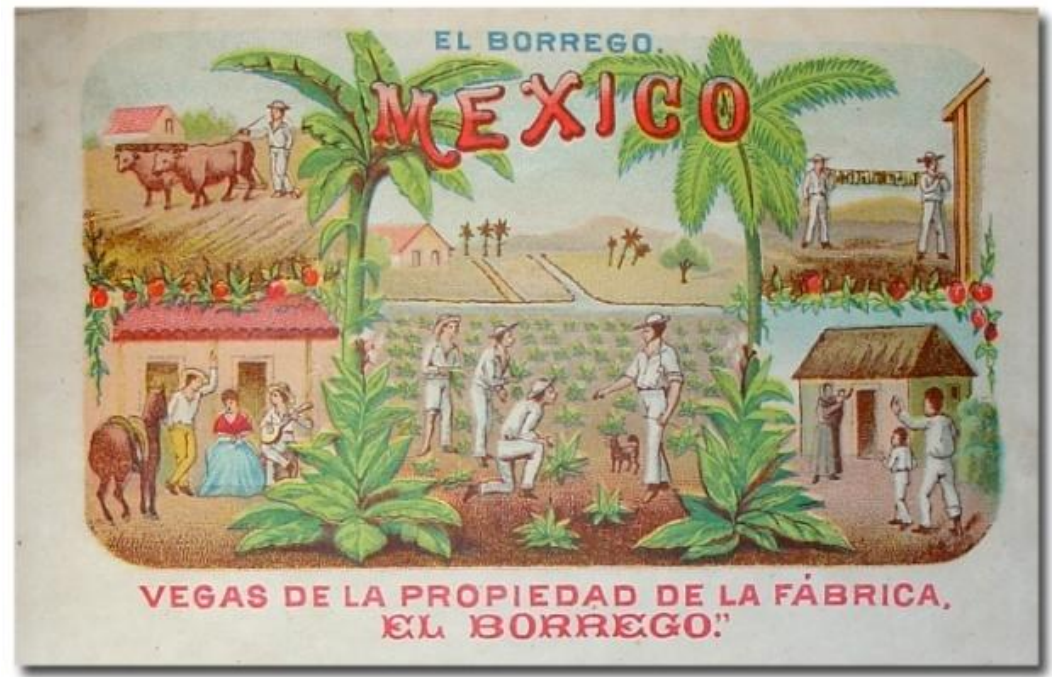

Figura 90 Vegas de la propiedad de la Fábrica El borrego Acequia 20 México, Litográfica Española 1884 


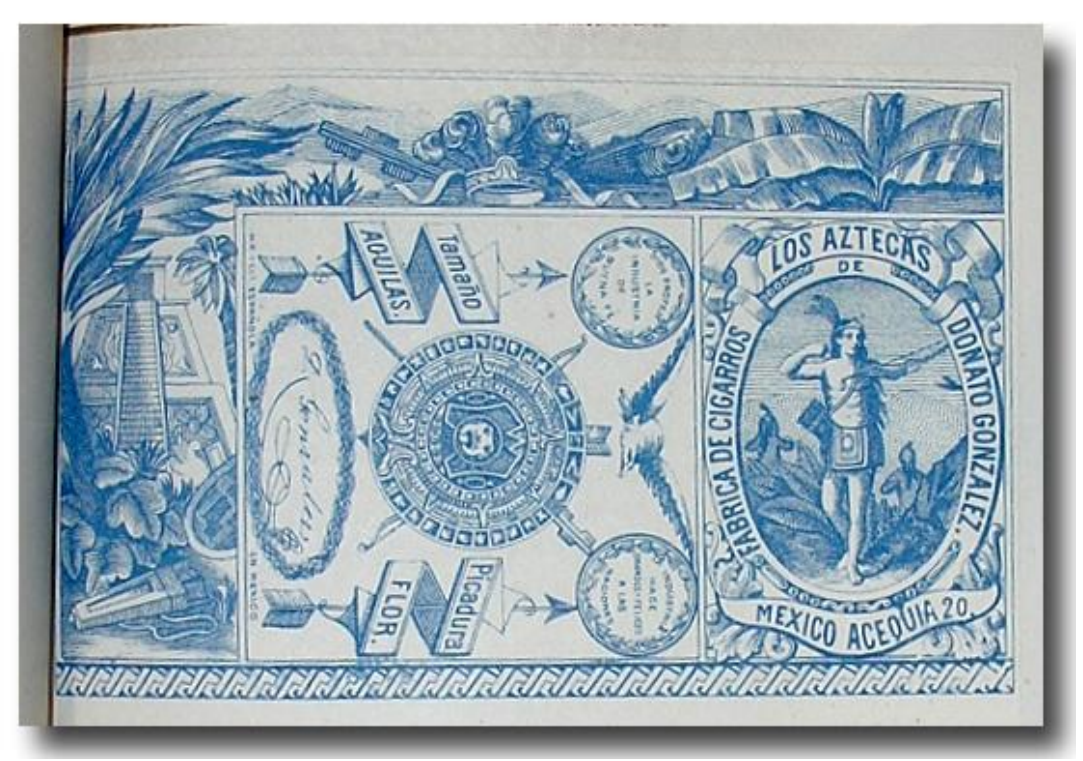

Figura 91 Los aztecas. Tamaño Águilas. Donato González México 1885

El problema era que los dueños de las fábricas impactados por la ley del timbre tenían que pagar impuestos por cada cajetilla de cigarros que salieran de las fábricas por lo que se vieron obligados a aumentar el trabajo de las obreras por el mismo salario. El Congreso obrero creyó conveniente realizar un acuerdo entre las obreras y los dueños de fábricas para que se estableciera un tipo de tarea única y obligatoria en todas las fábricas pero al no haber acuerdo se retiraron los dueños. Siguió una segunda reunión, pero los dueños enviaron a sus representantes para que leyeran un "ocurso" manifestando las razones que tenían para que se fijara en 2600 el número de cigarrillos que cada trabajadora debería realizar por día y que serían pagados a cuatro reales. Se llegó a 2500 cigarros en el acuerdo todas las fábricas excepto La Sultana de Manuel Rivero lo aceptaron, la última consideró que era libre de contratar a quien deseara y podía contratar a los presos de la cárcel de Belén por lo que quisiera pagarles. El acuerdo no se firmó y entonces Federico M. Fusco, 
director del periódico La Paz Pública apoyó a las obreras con gran cantidad de artículos y promovió una organización mutualista. El 11 de diciembre de 1887 desde las páginas de este periódico se anunció la creación de la Sociedad Mutualista Las Hijas del Trabajo del Ramo de Obreras de Cigarrería, nombrando entre su mesa directiva y comisiones a prestigiadas damas como presidenta de honor a Manuela Arango de Carrillo esposa del comandante militar del Distrito Federal, Carmelita Romero Rubio, esposa del Presidente Porfirio Díaz; Dolores Revueltas de Escudero y otras.

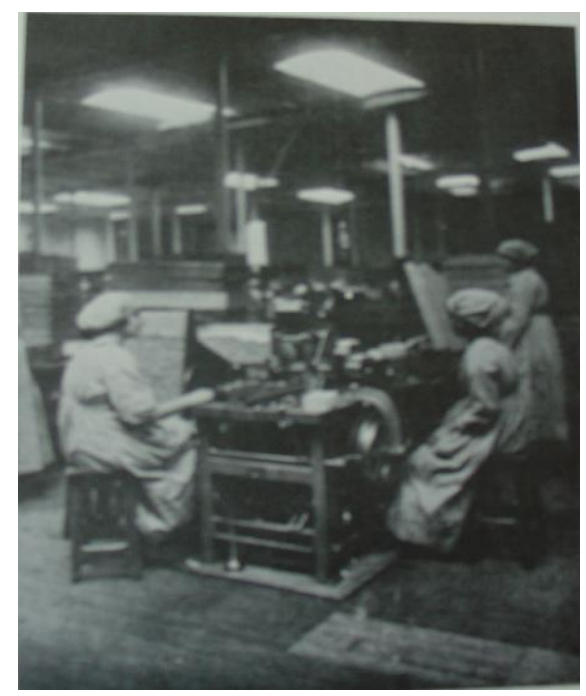

Figura 92 AGN Fondo Teixidor. Trabajadoras del Buen Tono

En julio del mismo año estalló otra huelga, en la fábrica La Ideal, las mujeres se inconformaron porque se les aplicaban multas sobre sus salarios, el dueño de la fábrica respondió a un reportero del periódico "El Monitor del Pueblo" que el fin de tales multas era "moralizar" y que sus productos se aplicaban a lograr un fondo para premiar a aquéllas que mejor realizaran sus labores. Esta no fue la última huelga de mujeres cigarreras. En 1888 Ernesto Pugibet 
introdujo la máquina para hacer cigarros, con lo que desapareció el trabajo de las mujeres cigarreras y la mecanización de la producción, vino a ser uno de los factores sociales más notables del fin de siglo.

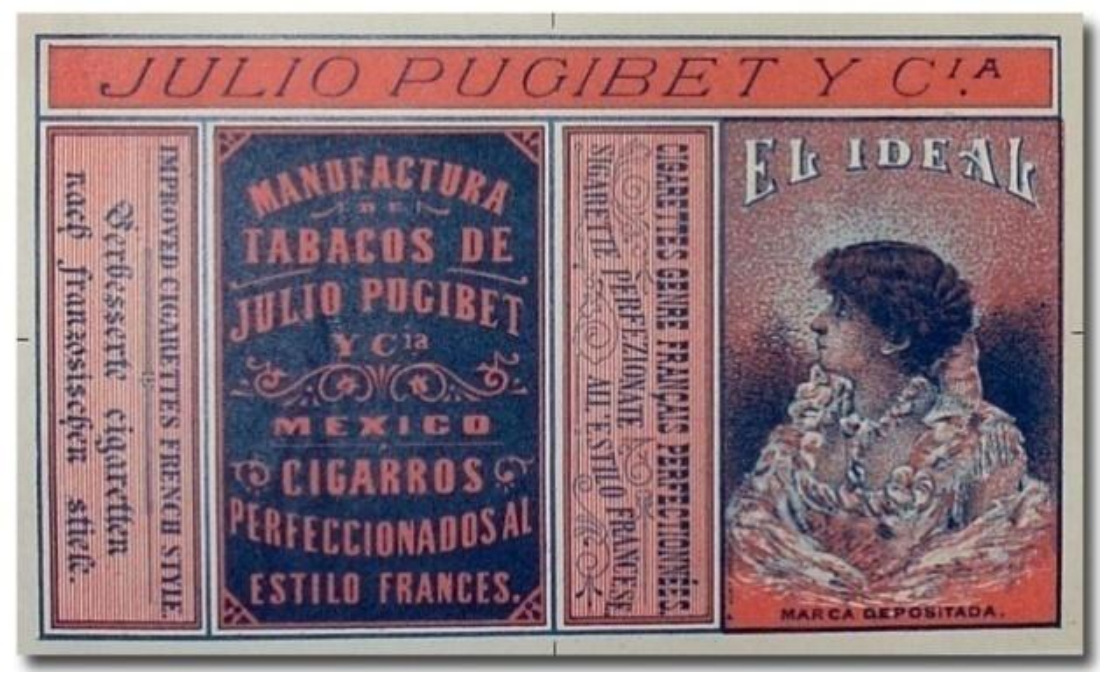

Figura 93 Marca "El ideal" manufactura de tabacos y litográfica de Julio Pugibet y Cía. Cigarros perfeccionados al estilo francés. 1885

Es indudable que durante la historia de México el tema del tabaco ha estado presente en códices, crónicas, novelas e iconografía actualmente se han realizado investigaciones en torno a los aspectos económicos que lo circundan así como su internacionalización, se ha abordado el tema de la salud y en lo que al fumar se refiere, las afecciones que causa. El tabaco, en general tiene un relato histórico importante, así que habiendo echado un vistazo a sus antecedentes: uso, consumo y producción abordaremos otro aspecto.

Nuestro trabajo de investigación gira en torno a la producción litográfica de etiquetas y empaques de puros y cigarros que se produjeron durante la segunda mitad del siglo XIX cuando ya en un ambiente de mayor estabilidad política, la técnica litográfica pudo 
provocar un importante avance en la publicidad de muchos productos. Las fábricas de puros y cigarros recurrieron a los talleres litográficos para lograr mayores y mejores ventas. Ahora sucederá a este capítulo el tema de la publicidad. 


\section{CAPÍTULO 3. EL TRABAJO PUBLICITARIO EN TORNO AL TABACO.}

En la última década del siglo XIX, se consideró a la publicidad, como un fenómeno que desarrollaría la competencia entre los diversos productos que se consumían en el mercado, entonces diversas firmas se enfrentaron a una lucha, en donde la creatividad en el diseño y las formas de publicitar, tenían un papel fundamental. Pero la difusión de un hábito como fumar, no se realizaba solamente por medio de etiquetas, tuvo grandes publicistas como las novelas, la poesía, las canciones, la pintura, y por supuesto la litografía.

\section{1 ¿EL ARTE DE FUMAR?}

La literatura no estuvo ajena, incluyó la acción de fumar, son algunos ejemplos: la poesía, los cuentos, las novelas costumbristas, los relatos realizados por algunos artistas mexicanos y extranjeros, etc.

Presentamos parte de una poesía publicada en 1806:

"Tu fuego las pasiones simboliza en que ansioso yo mismo me consumo, bebiendo el fuego que mi aliento atiza;

y si advierto tus voces, me presumo que me pintas mi fin en la ceniza y retratas mis gustos en el humo."71

\footnotetext{
${ }^{71}$ Manuel de la Torre Lloerda, Diario de México, 26 de diciembre de 1806. En: Historia y Cultura del Tabaco_Op. Cit. p.179
} 
En México era común ver a mujeres, niños y hombres fumar no importaba si eran indios, mestizos ó criollos, era una costumbre que se practicaba en casi todas partes, pero algunos personajes que venían de otros países la consideraban exótica, escandalosa y en ocasiones desagradable.

Entre el disfrute y la crítica que algunos extranjeros hacían sobre las costumbres mexicanas, fumar les resultaba motivo de relato, como es el caso de los Bullock. Padre e hijo habían llegado con la pretensión de extraer minerales, para lo que compraron una mina en Tlalpujahua, Estado de México. Durante el tiempo que residieron en el país, William Bullock hijo se sorprendió cuando al hacer un viaje a Xalapa, Veracruz, observó costumbre de fumar y escribió:

"En el curso de la primera noche que pasé, en una reunión social observé el humo que se levantaba sobre la cabeza de una dama que tocaba el piano: fui a cerciorarme del hecho y encontré que a pesar de estar comprometida con el instrumento, no abandonaba su cigarro puro, y expelía bocanadas de humo por la boca y la nariz"72

Sin tener éxito en su empresa, los Bullock, se retiraron a Estados Unidos.

Mme. Calderón de la Barca ${ }^{73}$ escribiría hacia 1839, después de asistir por la noche al Teatro Principal:

"Fumaba todo el patio, fumaban las galerías y fumaba el apuntador de cuya concha salía una rizada espiral de humo que daba a sus profecías un viso de oráculo délfico. La fuerza de fumar no podía ir más lejos. Un teatro ciertamente, indigno de esta hermosa ciudad".

"Que siendo tan general el uso del tabaco en humo en esta capital, no es fácil impedirlo en el Coliseo, pero que sí deba prohibirse el que los concurrentes arrojen desde la Cazuela y Palcos, yesca encendida y cabos de cigarros al patio, sucediendo no pocas veces que quemen los vestidos y

\footnotetext{
${ }^{72}$ Justino Fernández, "El atlas de la obra de Bullock" en: Anales del IIE, México, UNAM 1956. pp 23-33

${ }^{73}$ Mme. Calderón de la Barca. La Vida en México
} 
capas de las personas que ocupan los Palcos más bajos, Bancos y Mosquete"

Sobre todo en las obras litográficas, las de artistas extranjeros como Sartorius, Rugendas (fig.94), Linati, etc., constantemente presentan personajes fumando y esa costumbre la describen también en los textos que acompañan a las litografías:

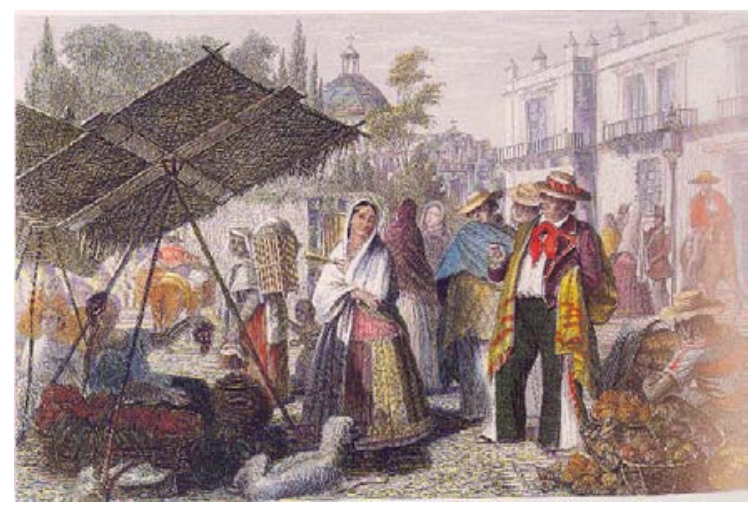

Figura 94 Johann Moritz Rugendas. "Placeros y rancheros"

"En el mercado (...) hay largas hileras de legumbres, frutas, flores, aves, etc. y todas las mañanas multitud de personas de diversas clases sociales recorren las callejuelas de este enorme bazar. El oficial y el oficinista, el artesano floreciente, el comerciante al mayoreo con su gran empleado, el abogado, el propietario de tierras y fincas, en su gran mayoría son blancos y se distinguen de los demás miembros de la población por su traje y su porte". C.C. Sartorius ${ }^{74}$

En varios periódicos fue publicado "El tabaco", de Ángel R. Chávez, escribía en este cuento que el tabaco había salido de la saliva de Mahoma, en donde Dios hizo germinar una planta, que tenía toda la dulzura de la boca del profeta (se refería a las hojas del tabaco procesadas en cigarros o utilizadas en pipas) y toda la amargura de la ponzoña de la ingratitud, representada por el rapé, al que denominaba hijo bastardo del tabaco. El tabaco, junto con el café

\footnotetext{
${ }^{74}$ Christian Sartorius, 1796-1872 México y los Mexicanos, con 18 il. Por M. Rugendas; vers. Selección y notas de Marita Martínez del Río de Redo. México, San Ángel Ediciones, 1995
} 
fue considerado -por el autor- planta que tenía la gloria de hacer pensar a la humanidad ${ }^{75}$.

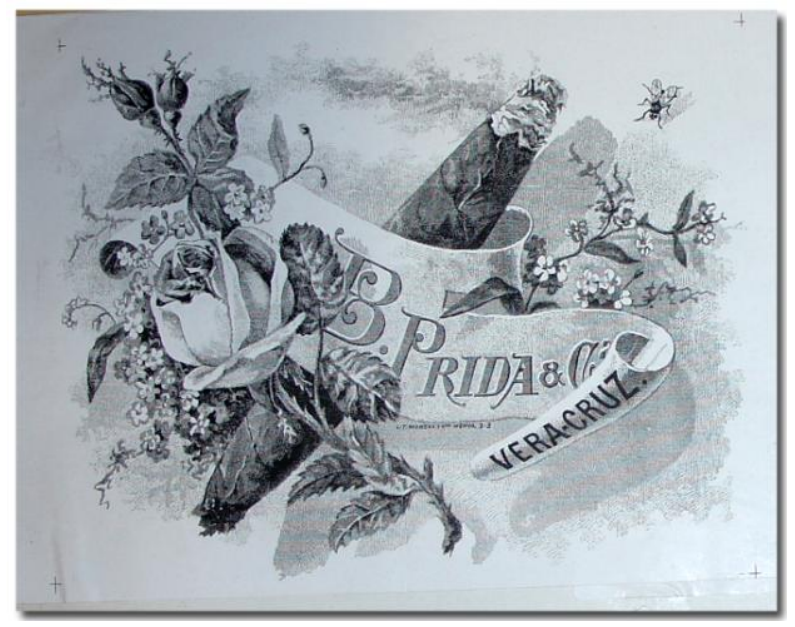

Figura 95. Prida y Cía. Veracruz Litográfica de Moreau y Hnos. México I-3

Eduard Pingret ${ }^{76}$ otro artista extranjero aún cuando viajaba haciendo negocios en México, continuó pintando -quizá atraído inicialmente por su interés en lo exótico- ejecutó durante sus viajes, obras en las que documenta la geografía y las costumbres locales, Pingret fue de los primeros artistas que pintaron escenas mexicanas tal como aparecían en la realidad. Expuso en la Academia de San Carlos en 1850 y en 1852 en esta última presentó cuarenta pinturas de costumbres y paisajes mexicanos, que fue muy bien recibida. Presentamos una imagen del aguador (fig.96) que era un personaje muy importante en el abasto de agua sobre todo para las casas ubicadas en el centro de la ciudad. Se encargaba de llenar los cántaros en las fuentes donde desembocaban los acueductos. En esta imagen el aguador se dirige hacia la fuente, porta un sombrero y

\footnotetext{
75 Ángel R. Chávez. "El Tabaco” en: El Álbum Mexicano. Op. Cit.
} 
un pantalón especial posiblemente de cuero con el que se protegía del roce constante de los cántaros sobre sus piernas.

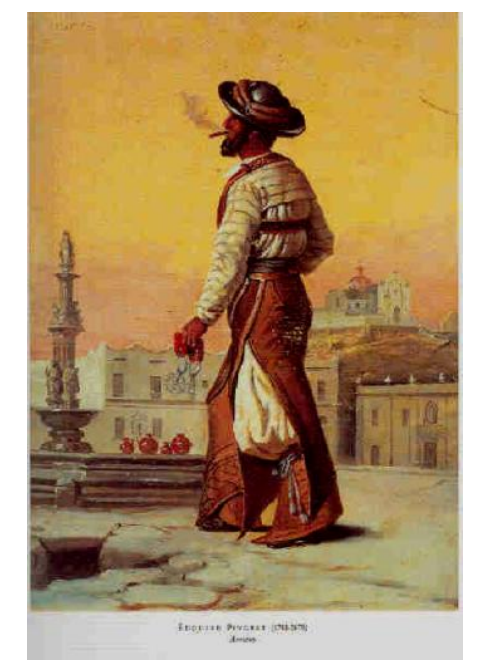

Figura 96 Eduard Pingret "El aguador".

\subsection{LA LITOGRAFÍA Y EL TEMA DEL TABACO}

Con la introducción de la litografía en México Linati hizo posible, reproducir a bajo costo, numerosas imágenes, que acompañaron obras literarias. En "El Iris" revista publicada por José María Heredia (poeta cubano) Linati publicó las primeras litografías que se hicieron en México en 1826. Este autor también publicó en Bruselas en 1828, Costumbres civiles, religiosas y militares de México $^{77}$. Obra acompañada con descripciones de su experiencia en México (1826 a 1832). Respecto al tabaco encontramos la imagen de un lépero vagabundo (fig.97), representado por un hombre fuerte vestido en harapos recargado sobre una pared, aparentemente sin que le importe el tiempo o el trabajo, fuma su cigarro, en espera o pensando en "algo". Su sombrero, está

\footnotetext{
${ }^{77}$ Claudio Linati. Trajes de civiles, militares y religiosos de México, México, Porrúa, 1979. Ilustraciones 1,3 y 20
} 


\section{recargado de la misma manera que él: sobre la pared. Al lado del lépero el perro, lo mira, y aguarda que pronto suceda ese "algo".}

“..sin camisa y sin zapatos, un trozo de cuero y una manta de lana forman su indumentaria. Esta misma cobija se convierte en cama durante la noche y la entrada de un portal o las gradas de una iglesia le sirven de habitación..."78

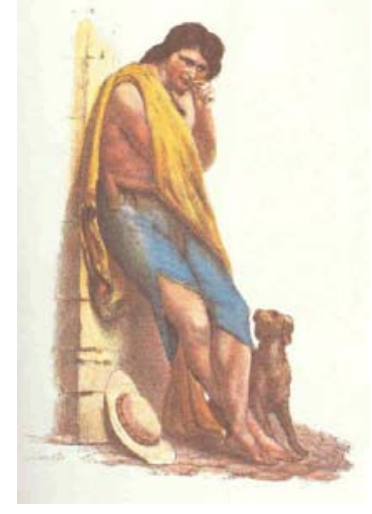

Figura 97 Linati. "El lépero".

\section{Claudio Linati escribió, refiriéndose al "Carnicero mexicano" (fig.98)}

"Los mexicanos tienen una predilección decidida por servirse de otras piernas que no sean las suyas...el intrépido lépero tiene demasiado horror al movimiento pedestre...el humo del cigarro que le sale por la boca, podría provocar que cualquier imaginación exaltada lo tomara por un vampiro que se sacia de cadáveres y cuyo aliento abrasador se esparce por los aires..."

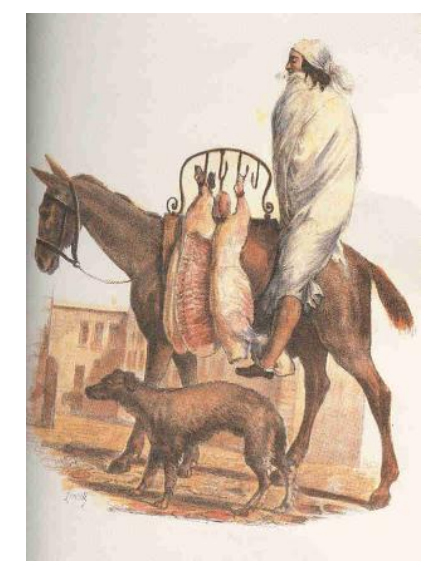

Figura 98 Linati “El carnicero”

\footnotetext{
${ }^{78}$ Idem
} 
En la imagen del "Negro recostado en su hamaca" (fig.99) Linati anotó la costumbre de fumar asociada con el ocio:

"El negro liberado balanceándose muellemente en su hamaca de hojas de áloe, se procura un largo fuete para despertar la actividad de su compañera, porque a ella reserva todas las penalidades del quehacer..."

En esta litografía pintada con acuarela observamos que el negro, además de balancearse en la hamaca y golpear a su compañera con un látigo, puede plácidamente sostener un cigarro entre los dedos.

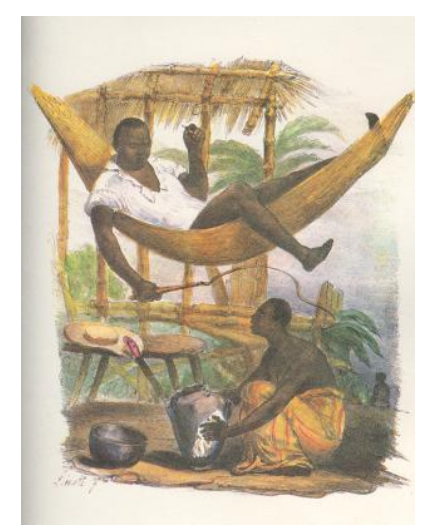

Figura 99 Linati. "El negro acostado en su hamaca"

El Atlas Pintoresco de la República Mexicana fue publicado entre los años 1848 a 1856. Los dibujantes de esta obra fueron Frédéric Lehnert ${ }^{79}$ y Urbano López, sus obras no son originales, fueron tomadas y modificadas de Carl Nebel y Pedro Gualdi, artistas extranjeros que estuvieron en México entre 1828 y 1851. Las litografías fueron impresas en la imprenta de Lemercier en París y la litografía de Prodhomme, que tenían relación con la estampería de

\footnotetext{
${ }^{79}$ Pierre-Fredric Lenhert fue pintor, grabador y litógrafo. Francés especializado en figuras de personas y animales ganó varios premios en la Academia de París. Urbano López hizo gran parte de los dibujos del paisaje arquitectónico, fue un grabador que en 1851 realizó vistas de Granada, dos de Segovia y una aguada del convento de Batuecas.
} 
Julio Michaud "Junto al correo" en donde después se vendían en México. En un detalle de la litografía (Fig.100) observamos a una mujer fumando un cigarrillo, viste una blusa con escote redondo y holanes, una falda de la que asoma un fustán con picos bordados y un refajo rojo en la cintura. Está acompañada de otros personajes: a su izquierda, un hombre con sombrero, va cubierto con un "zarape veteado" viste un pantalón de los usados por los chinacos, da la mano a una mujer que cubre su cabeza y hombros con un rebozo, apenas se puede ver un refajo en su cintura y una falda amplia con grecas que seguramente eran "bordadas a mano". La escena se lleva a cabo enfrente del Palacio Nacional en el centro de la ciudad de México. En la parte superior del portal principal ondea una bandera. Al centro de la composición observamos al clérigo que saluda a una dama.

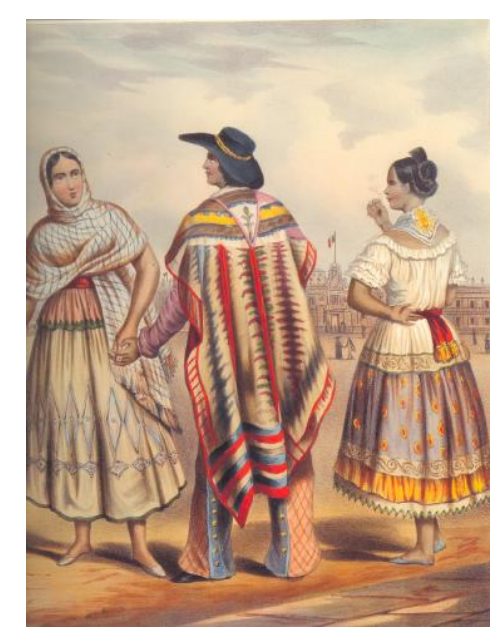

Figura 100 Álbum Pintoresco de la República Mexicana 1849 - 1852

Luis G. Inclán e Ignacio Manuel Altamirano promovieron la descripción del mexicano en cuanto a sus costumbres y entorno, aparecen como eco obras costumbristas, novelas, ensayos. La obra plástica quedaría representada por Posada, Juan Bautista Urrutia, 
Hesiquio Iriarte, Heredia, Escalante, José Guadalupe Posada, entre otros.

El Álbum Mexicano ${ }^{80}$ presenta una historia novelada del tabaco desde sus orígenes hasta el momento en que la obra se publicó en 1848, apoya al texto una litografía a color con objetos que la acompañan, pipas, puros, cigarrillos, pebetero y una cajita de rapé. (Fig. 101)

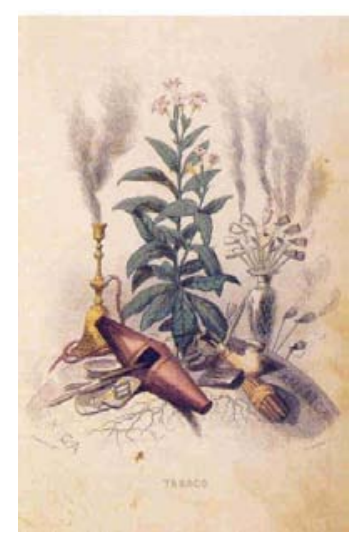

Figura101 "El Tabaco”. En: El Álbum Mexicano.

Hesiquio Iriarte y Campillo dibujaron y litografiaron las imágenes de Los mexicanos pintados por si mismos ${ }^{81}$, es una obra escrita por varios autores: Hilarión Frías y Soto, José María Rivera, Juan de Dios Arias, Ignacio Ramírez, Pantaleón Tovar y Niceto de Zamacois. Haciendo a un lado el análisis del dibujo y de la perspectiva, esta obra trata de representar los tipos y costumbres que imperaban en México a finales del siglo XIX. La técnica litográfica es buena, los detalles muy cuidados, la línea es suave, este litógrafo se inspiró en imágenes europeas que representaban

\footnotetext{
${ }^{80}$ El Álbum Mexicano, México, Imprenta de Ignacio Cumplido, 1848.

${ }^{81}$ Los mexicanos pintados por si mismos. Reproducción facsimilar de la de 1855, México, Porrúa, 1974
} 
los tipos y voces populares ${ }^{82}$. El objetivo de esta obra fue afirmar la identidad nacional, es decir, recuperar el acontecer cotidiano por medio de imágenes y descripciones ${ }^{83}$.

Observamos que el tema del tabaco era recurrente y a continuación reproducimos algunas narraciones:

El cajista (Fig.102) sostiene entre los labios un cigarrillo que se consume paulatinamente, vestido con un bombín, chaleco, y corbata de moño, no nos pasa desapercibido su pantalón estrecho con un delantal o mandil (como una pañoleta) que usaban algunos impresores para protegerse de las manchas de tinta. Un mueble con cajas de tipos móviles a su derecha y al fondo observamos otros personajes que formaban parte de este taller.

\footnotetext{
"Más por desgracia la mayor parte de los cajistas (malos por supuesto) están reñidos con el arte de las comas y los puntos, con una poca diferencia siguen el método de aquel compositor americano, el cual habiéndole preguntado qué reglas seguía para la puntuación, contestó: que iba leyendo y componiendo hasta donde le llegaba la respiración, y entonces ponía una coma; cuando bostezaba ponía punto y coma; un estornudo exigía la colocación de dos puntos; y la necesidad de una nueva mascada de tabaco era regla para poner punto y aparte". 84
}

\footnotetext{
${ }^{82}$ Los españoles pintados por si mismos, Los franceses pintados por si mismos (1844) voces populares

${ }^{83}$ La obra fue escrita por una sociedad de literatos de mediados del siglo XIX a excepción de uno no firmaron sus trabajos el resto ostenta al final del capítulo un signo ortográfico o una inicial que no es ni el nombre ni apellido del autor.

${ }^{84}$ José María Rivera, "El cajista” en: Los mexicanos pintados por si mismos_México, Símbolo, 1946. p. 170
} 


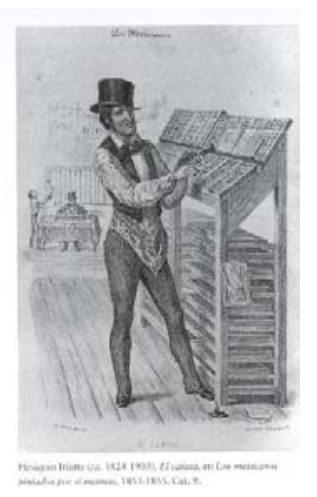

Figura 102 El cajista

En la imagen una mujer de las que se denominaban "Chinas" (fig.103) se observa en actitud coqueta, segura, fuerte. En la imagen la china en "jarros"85 sostiene en su mano derecha un cigarrillo y el escenario es una cocina típica con fogón sobre el cual se encuentra una olla de barro para cocinar frijoles: En las paredes y en el estante se colocan diversos objetos, un "aventador" 86 " o "chiquihuite", caballitos de juguete, botellas etc. y en el piso dos palomas comen tal vez mendrugos.

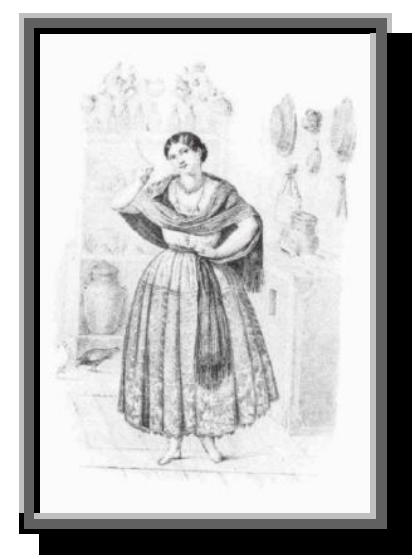

Figura103 "La china". Los mexicanos pintados por si mismos

\footnotetext{
${ }^{85}$ Se dice en el argot popular "en jarros" a la persona que cierra los puños y los acomoda a los lados de su cintura.

${ }^{86}$ Aventador o chiquihuite es un tipo de abanico hecho de palma, con lo que se atiza el fogón.
} 
Algunos litógrafos eran humoristas, en las caricaturas tanto políticas como religiosas y sociales dibujaban el acontecer mexicano y la particularidad del mexicano por hacer bromas con respecto a las catástrofes o utilizaban el doble sentido, el albur, o la denuncia apoyadas con imágenes litográficas.

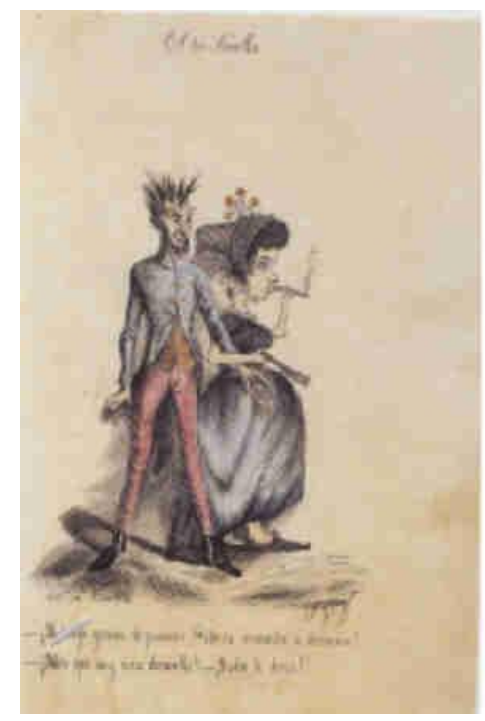

Figura 104 -No tengo ganas de pasear señora, comadre o demonio! - ¡Mire que soy una doncella!- ¡Nadie lo diría!

Casimiro Castro (1886-1889) publicó muchas obras entre las cuales se encuentran: México y sus alrededores (1855-56). Es un compendio de artículos escritos por Francisco Zarco, Niceto de Zamacois y otros en esta obra es fundamental el dibujo de multitudes, el abastecimiento de productos, la convivencia entre los diversos estratos sociales y etnias y el Álbum del Ferrocarril Mexicano $^{87}$ (1878) que relata la historia de la travesía de México a

\footnotetext{
${ }^{87}$ Álbum del ferrocarril mexicano. México, Víctor Debray y Cía. Facsimilar de Papel y Cartón de México 1996. Las cromolitografías son de Casimiro Castro.
} 
Veracruz, la obra está acompañada con el texto de Antonio García Cubas $^{88}$..

Campillo era un litógrafo y dibujante que trabajó en diversos talleres como el de Casimiro Castro. Su dibujo acucioso, cuidadoso con la técnica, buen oficio en general. En la obra Trajes Mexicanos (Figs. 105 y 106) nos ofrece la representación de personas fumando: Observamos una escena campirana y atrás el convento de San Francisco.

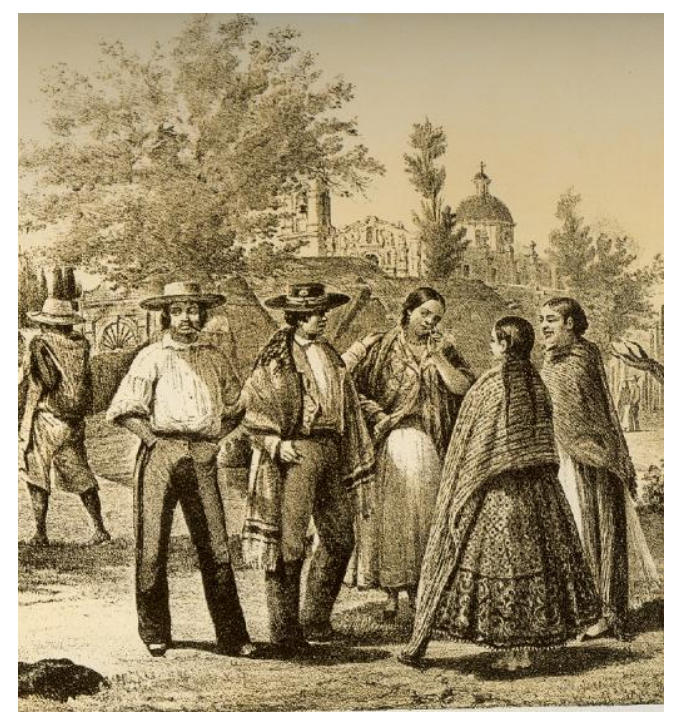

Figura 105 Campillo, Trajes mexicanos.

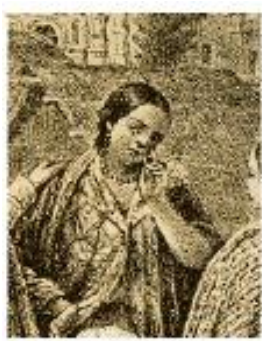

Figura 106 Detalle

La litografía que presentamos a continuación (figs. 107 y 108)es tomada de la obra México y sus Alrededores se denomina "El jarabe", observamos en detalle a un hombre que tiene un puro en la mano derecha, con la otra ofrece un sorbo de pulque a una mujer

\footnotetext{
${ }^{88}$ Antonio García Cubas 1882- 1912, ingeniero topógrafo, historiador, fue considerado el mejor geógrafo del porfiriato.
} 
que arrodillada sobre el suelo, hace las tortillas para "echarlas al comal" que descansa sobre un fogón, alrededor de la mujer, se observa la bola de masa, una batea de madera y ollas que seguramente contenían agua. En las paredes cuelgan canastas y diversos objetos de uso cotidiano.

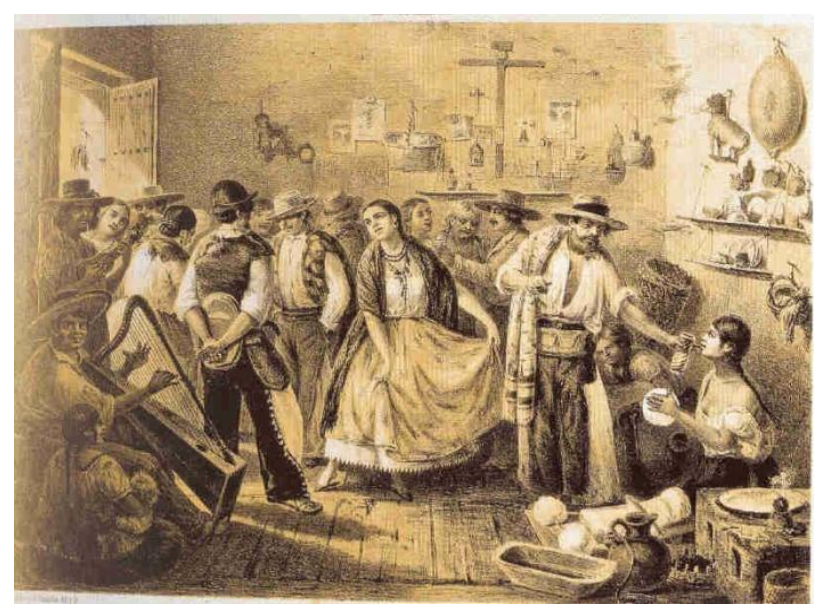

Figura 107 El Jarabe. Dibaㅗ y Lit ${ }^{\mathrm{a}}$ Campillo. En: México y sus Alrededores

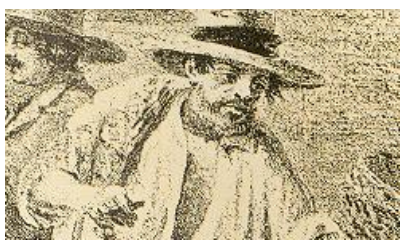

Figura 108 Detalle

\subsection{LAS ETIQUETAS COMERCIALES.}

La historia de las etiquetas comerciales nos indica que no solamente eran útiles para conocer qué producto contenía un empaque sin necesidad de abrirlo, hasta el siglo XIX fueron definidos con claridad algunos elementos que las etiquetas deberían de incluir como: producto, lugar de origen, el costo, fábrica, dueño de la fábrica, lugar en donde se podían comprar los productos, y especialmente algunas frases para alentar su compra y ostentar el producto como mejor que otros, en el más puro sentido de competencia de mercado. De tal forma que no solamente organizar 
el producto en el empaque sino publicitarlo fueron elementos para mejorar su presentación y cuidar que no sufrieran desperfectos durante su distribución. La calidad de las imágenes y los mensajes contenidos en estas etiquetas definían, aún antes de probar el producto, la aprobación de su compra. Daremos un vistazo a la historia de la etiqueta como factor de publicitación de productos.

\subsubsection{La evolución de la etiqueta como factor de publicidad.}

"Las grandes ciudades, en todo el mundo se observan ataviadas con etiquetas, la publicidad de los productos ha rebasado el espacio de los empaques y han subido a los edificios y espacios aéreos a través de los espectaculares. El origen de las etiquetas, se remonta a los primeros asentamientos urbanos" 89 .

Desde que se inició el uso de las etiquetas su función fue informar. Los ejemplos más remotos los encontramos en Nippur, Mesopotamia año 3000 a. C, se colocaban sobre jarros la cerámica presenta aún restos de mezclas de hierbas y residuos de compuestos medicinales. También en Egipto se registran envases de alabastro con productos para sanar o embalsamar cuerpos.

Los lekythoi (Fig. 109) de los griegos eran utensilios de cerámica y barro decorados con imágenes relacionadas con sus contenidos, su dueño o el artista que los realizaba. En Roma clásica se utilizaron vasijas de cristal para colocar medicamentos con inscripciones relativas sus contenidos.

\footnotetext{
${ }^{89}$ Dolores Vidales Giovannetti. “Una Historia de Etiqueta. Las primeras etapas de la Etiqueta”, en: Colección de Estudios Históricos 8 UAM Azcapotzalco.
} 


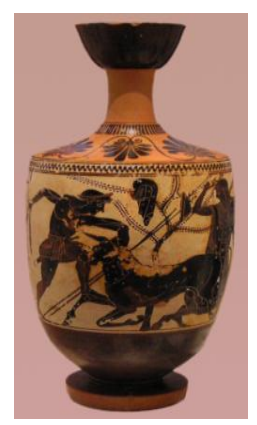

Figura 109 Lekythoi

En la ciudad de Uruk se encontraron listados de productos agrícolas y números hechos en tablillas, que representaban la realidad, fueron denominados pictogramas y constituyeron un factor importante en el comercio y la economía de las ciudades. Desde entonces y hasta nuestros días podemos determinar que las funciones de las etiquetas son: identificar, comunicar y brindar un impacto estético.

Los ideogramas, pictogramas, fonogramas etc. se utilizaron poco a poco como elementos estéticos que impactan visual y acústicamente a los que los interpretaban y propiciaron adquirir información precisa de los productos que las etiquetas publicitaban.

Para concretar un concepto o transmitir información, los egipcios elaboraron manuscritos ilustrados, combinaron palabras y dibujos. Colocaban dentro de los sarcófagos y junto a los cuerpos momificados canopes que eran objetos que contenían las vísceras momificadas (fig. 110). Este ritual tenía un sentido sagrado, a cada órgano correspondía aun dios protector. La vasija estaba decorada con inscripciones que señalaban su contenido y al Dios que le encomendaban la protección o cuidado de esas vísceras: Hapi era el 
dios encargado de proteger los pulmones, por tanto la tapa del recipiente tenía la forma de la cabeza de un mandril. Imseti protector del hígado, la tapa del recipiente tenía la forma de cabeza humana, Dua-mut-ef cuidaba el estómago, la tapa representaba la cabeza del chacal y, por último Qe-beh-senu-efr encargado de cuidar los intestinos, el canope tenía una tapa en forma de cabeza de halcón.

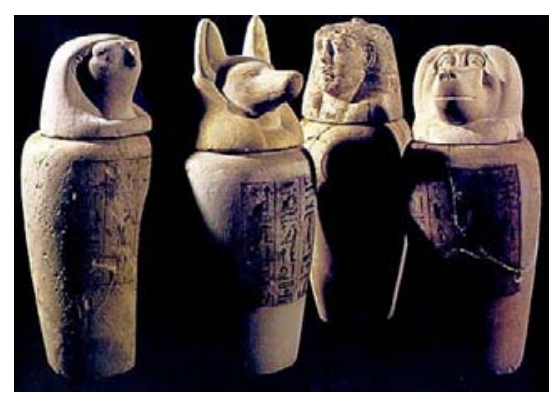

Figura 110 Canopes

Los egipcios utilizaron también sellos cilíndricos y marcas para identificar visualmente al comprador, al fabricante, propietario, el creador de un objeto e incluso el nombre de la persona que lo había regalado. Las vasijas, frascos, perfumeros y otros utensilios domésticos incluyeron datos sobre sus contenidos y las personas que los utilizarían.

Por otra parte, en China la representación de las cosas se realizó a través de pictografías que son imágenes fácilmente descifrables compuestas por un número mínimo de líneas que junto con el grabado, el laqueado y las tintas formaban piezas muy bellas a las que se les agregaban leyendas que indicaban el contenido de los envases. Mediante esta técnica se comercializaron especias e inciensos. Como el proceso de escritura china tenía un sentido divino, Tsäi Lun inventor del papel, llegó a ser venerado como dios de los fabricantes de papel porque a través del uso del papel la 
escritura permitió se fomentara el vínculo entre el espíritu de un individuo con los otros, es decir, ayudó a la difusión de las ideas y sentimientos entre los mortales.

Al paso de los siglos, la imprenta derivó de los sellos grabados y su impresión en relieve identificaba marcas provocando la necesidad de ampliar la información y obligó que el contenido informativo de los sellos se ampliara.

La mayoría de las culturas, se manejaron principalmente a partir de la proyección visual, la pictografía se convirtió en un tipo de escritura de acertijos, ideografías, logogramas y hasta silabarios, pero muy pocas personas adquirieron estos conocimientos por lo que ostentaban gran poder.

Durante la época medieval para elaborar, conservar alimentos y procesar algunos medicamentos, se utilizaron condimentos y especias, sus contenedores eran muy sencillos, casi siempre vasijas austeras para uso casero. Cuando los turcos selyúsidas invadieron los llamados "lugares santos" se fueron transformando los conocimientos científicos, las técnicas de escritura, las formas de envasar y preservar alimentos, o embalar mercancías desarrollándose diferentes tipos de inscripciones en el texto de las etiquetas. La xilotipografía o impresión en relieve, fue utilizada junto con la tipografía que se diferenciaba de la primera por utilizar piezas de metal, independientes, móviles e intercambiables. Cada una tenía una letra encima. 
La catalogación, identificación y acopio de productos en el área de la salud se expandió durante los siglos XIII y XIV. Los primeros recipientes de botica no tenían etiquetas (Fig 111) por lo que se utilizaban y reutilizaban.

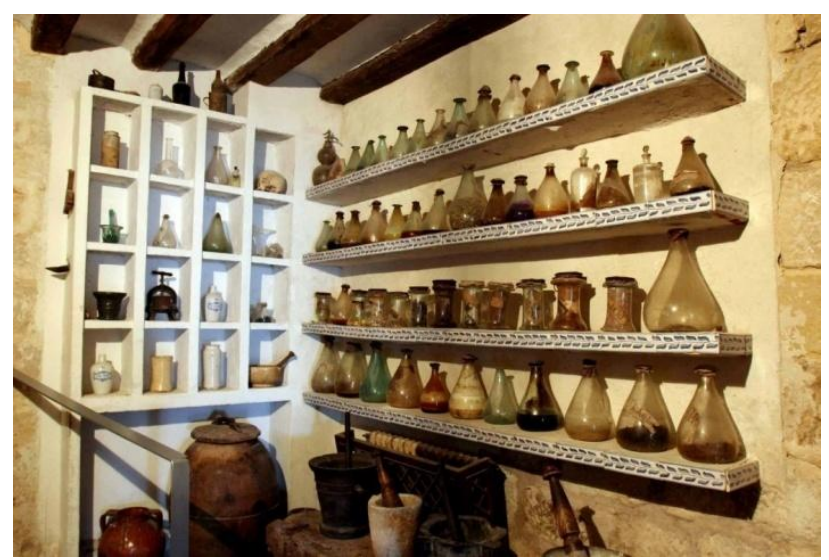

Figura 111 Frascos de Botica

Conforme pasó el tiempo, cada envase tenía un espacio para colocar una etiqueta. Hasta el siglo XV se incluyó en el diseño del frasco el nombre del producto contenido se utilizaron los famosos "jarrones de boticarios", "botes de farmacia" ó "botes de medicamento" que formaban colecciones de materias primas que se combinaban para provocar los remedios (fig.112) los boticarios los catalogaban según el "Antidotario" que era una lista de fármacos, compuestos y fórmulas recomendadas por las autoridades médicas y farmacéuticas de la región, la cantidad de productos y su variedad obligaron a que el número de estantes para guardar o exhibir los productos fuera muy extenso. Al principio, los recipientes tenían motivos geométricos inspirados en la decoración árabe y poco a poco adoptaron escenas de tipo seglar o religioso. Se representaban científicos, santos, símbolos, escudos de armas de los 
farmacéuticos, del hospital o de la orden religiosa a la que pertenecían.

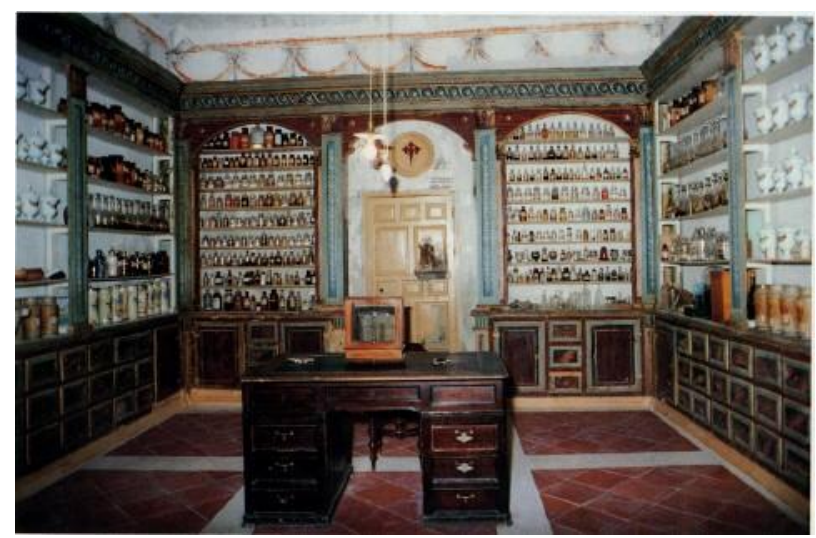

Figura 112 Botica $^{90}$

Muchos grupos de productores y comercializadores promovían mercancías que eran apreciadas en diversas regiones o en otros países. Durante el XVI por ejemplo, se vendía el vino en garrafas marcadas o se colgaban etiquetas de plata o marfil alrededor del cuello de la botella para determinar la cosecha y los tipos de vinos, pero el sistema industrial de producción, comercialización y consumo diferenciado como la cerveza en Alemania, el aceite o aguas aromáticas preparadas por los monjes dominicos en Florencia, el licor en los monasterios de Francia, el "Polvo de los jesuitas" conocido actualmente como quina, los "polvos de los capuchinos" que era un compuesto preparado a partir de la cebadilla y poderoso anti parasitario o los "Polvos de los cartujos" que era un producto descongestionante estomacal tenían que ser trasladados a otras regiones por lo que la demanda de estos productos hicieron que la producción aumentara. Muchos envases y sus etiquetas fueron incluidas en pinturas de la época.

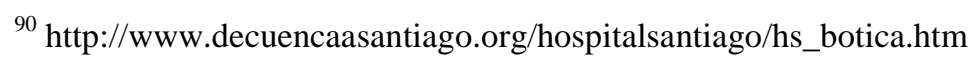


La hagiografía cristiana con más de setenta santos dedicados a las cuestiones de salud dieron pauta para la impresión de etiquetas para publicitar medicamentos: san Cosme y san Damián gemelos cristianos árabes se dedicaban a sanar y fueron ejecutados por el tribuno Dioclesiano, entre los años 303 al 313, convirtiéndose en mártires. Las imágenes de Cristo fueron frecuentes, como "Sanador" recordaban los milagros curativos enunciados en el Nuevo Testamento, estas imágenes datan de 1519 a 1528. En 1619 aparece la figura de Cristo farmacéutico sosteniendo un juego de balanza y rodeado de frascos con medicamentos que tenían etiquetas cuyos contenidos de origen divino eran por ejemplo: "Llave del cielo", "Consolación", "Raíces de la Cruz", "Hierba de la gracia divina" etc.

Al final del Renacimiento los morteros en los que se machacaban las hierbas y se mezclaban los medicamentos fueron labrados a mano, pulidos o fundidos en molde destacando hermosas figuras y paisajes. En cuanto a los frascos o empaques al final de este periodo se prefirió, en lugar de imprimirlas, colocar una etiqueta escrita a mano con el apoyo de copistas diestros en elaborar tintas y hacer diseños con el alfabeto romano estilizando las letras y en ocasiones realizando algunos dibujos.

Los productos circularon del mercado nacional, al internacional aumentando las distancias y la forma de transportación, los recipientes y su embalaje tuvieron que hacerse con mayor cuidado y resistencia. Por tanto, el uso de las etiquetas comerciales se generalizó en todo el mundo y fueron el germen del diseño gráfico. 
En el caso del mercado mexicano del tabaco como su comercialización se abrió hacia otros países durante el siglo XIX fueron diseñadas gran cantidad de etiquetas de cigarros y puros en las que se informaba: el tipo de tabaco, el dueño de la fábrica, la dirección de los estancos o depósitos, el nombre de la marca, costo del paquete, etc. Fue necesario que pasaran muchos años para que pudieran conjuntarse en México, tres elementos que afirmarían en todo el mundo el gusto por fumar: El tabaco, el papel y la litografía.

\section{4 "HABILITACIONES” Y OTRAS IMÁGENES.}

Las características de clima y suelo hicieron de México un país ideal para desarrollar la empresa del tabaco en 1877 funcionaban trece fábricas de cigarrillos entre las que se encontraban: "El Ideal", "La Bomba" y "Los Aztecas" propiedad de Donato González quien fabricaba las marcas:"Los Aztecas", "Arrobadores para señoras", "Los patriotas de América", y "El cinco de mayo".
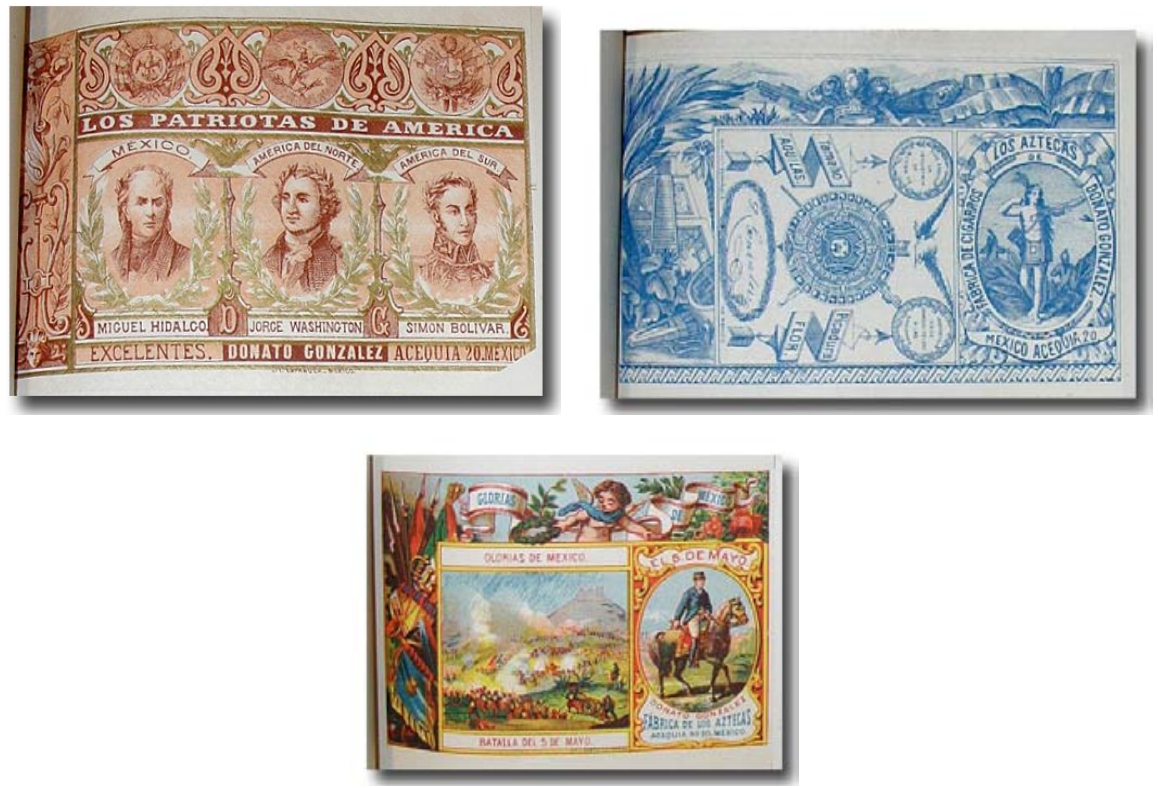

Figuras. 113,114 y 115 Etiquetas Registro de autor: Donato Guerra. Acervo Lino Picaseño 
Rafael Campos con su hermano Teodoro eran dueños de la fábrica "El Gallito" en la que se fabricaban también cerillos (Fig. 116).

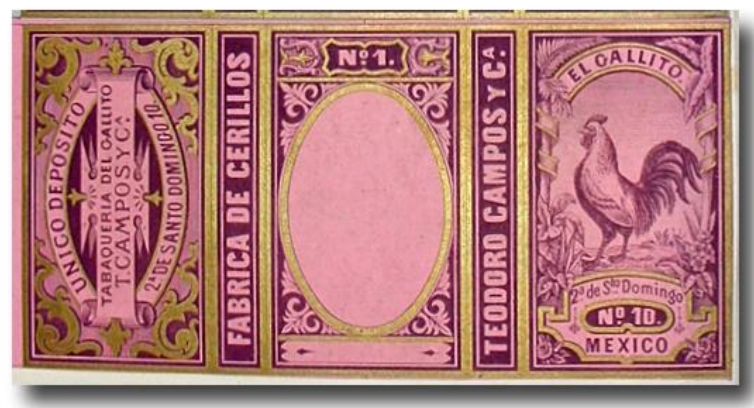

Figura116 "El Gallito" Fábrica de cerillos No 1 Teodoro Campos y

Ca. 2da de Sto. Domingo No 10 México. Único depósito.

Tabaquería del Gallito T. Campos y Cía." Sto. Domingo 10

Ramón Ampudia de origen español era dueño de la fábrica "El Modelo", realizaba su publicidad a través de las etiquetas que distinguían sus productos de los de sus competidores. Las etiquetas presentan una gran variedad de estilos, colores, tamaños y temas y de acuerdo con los acontecimientos políticos, se dibujaban e imprimían algunas etiquetas que hacían mofa o apoyaban estos eventos ${ }^{91}$.

Algunos autores presumen que en Cuba en 1822 se establecieron algunas compañías litográficas porque desde 1833la exportación de tabaco iba creciendo, de modo que los tabacaleros se encontraban ante la necesidad de proteger el producto de posibles fraudes y darle una presentación que estuviera de acuerdo al éxito que estaba adquiriendo, especialmente los puros se transportaban en mazos de

\footnotetext{
91 Arturo Obregón Martínez El siglo XIX Economía y Tabaco. En: María Concepción Amerlick et. Al. Historia y Cultura del Tabaco en México. México, Sría. de Agricultura y Recursos Hidráulicos. Tabacos Mexicanos, 1988. P 169
} 
50 o 100 colocados en cajones de madera de pino que llegaban a contener de cinco mil a diez mil puros, pero la única identificación que tenía el producto era la marca de hierro que se imprimía sobre los cajones en los que solían estar los nombres de la fábrica, fabricante y la dirección del lugar de procedencia y coincidía con la que contenía el papel de envoltura ${ }^{92}$. En los años 1850 y 1865 entraron en funcionamiento las empresas "Litografía del Gobierno Español" "Real Sociedad Patriótica" "Litografías de Tiburcio V. Cuesta" "Litografías de París" entre otras. Para entonces se implementa el uso de las cajas para puros, resurge definitivamente la habilidad de decorar las cajas de forma llamativa y delicada. La forma colocación de las etiquetas en las cajas, estaba localizada principalmente en la parte superior de lo que era la tapa y en la parte interior de ésta, o sea que al abrirse la caja, se observaba otra bella litografía. Con el tiempo se fueron añadiendo otros perfiles de decoración, hasta llegar a forrar totalmente la caja tanto en su interior como en el exterior, así se procede actualmente, perfeccionando las impresiones, pero siempre mantienen la estructura de sus inicios ${ }^{93}$.

Hacia 1895 inició la guerra de independencia en Cuba, por esta razón arribaron primero a Veracruz y luego a la ciudad de México algunos industriales tabacaleros que establecieron sus propias empresas. Es el caso de Julián Álvarez con la marca de Henry Clay, Habana y registró sus etiquetas y marcas en México.

\footnotetext{
${ }^{92}$ Florencio Giménez Caballero y Manuel López Rodríguez. Cien Anillas de Calidad en la Litográfica Tabacalera. Sevilla, España, Giralda, 1998 pp 49-50

${ }^{93}$ Enrique Curet Fuentes : Florencio Giménez. Club de Fumadores por la Tolerancia. Arturo Vergara. En http://www.galeon.com/cigarros/curiosidades.htm
} 


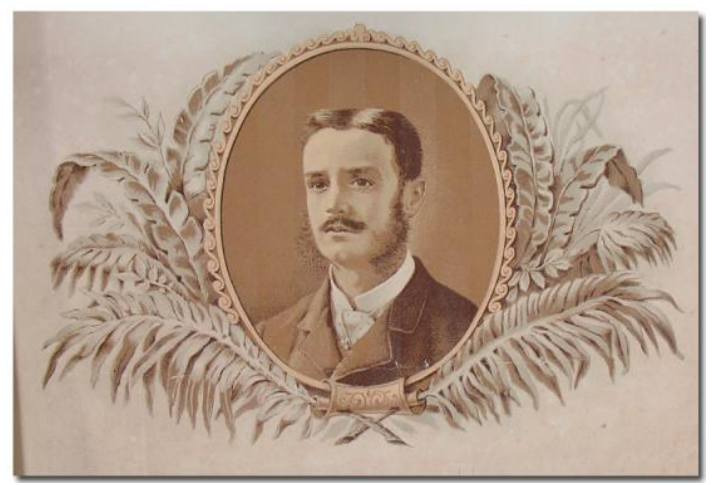

Figura 117 Julián Alvarez

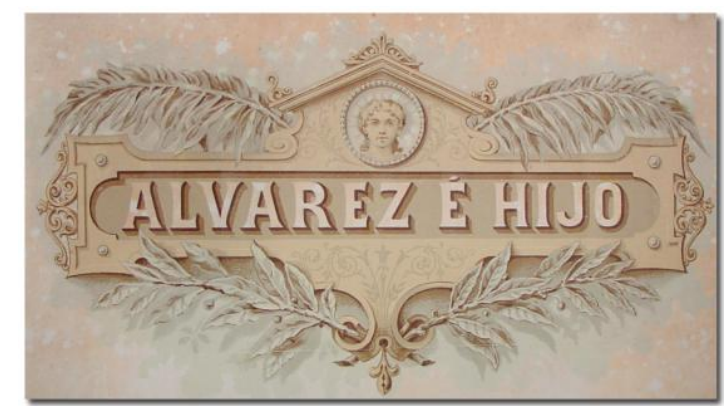

Figura 118 Alvarez e Hijo

Julián Álvarez (Figs. 117 y 118) y su hijo registraron la marca de la fábrica "La Selecta". Al morir Julián Álvarez en 1886 su viuda e hijo Francisco Álvarez adquirieron la propiedad de la fábrica y "La selecta" pasó a ser una marca anexa. La familia Álvarez vendió la fábrica a una asociación industrial inglesa representada por Gustavo Bock, pero "Henry Clay" mantuvo su condición de fábrica y la marca principal. 


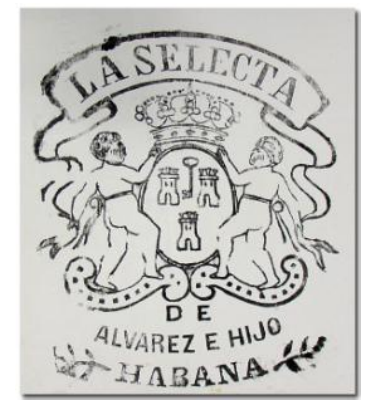

Figura 119“La selecta” De Alvarez e Hijo. Habana

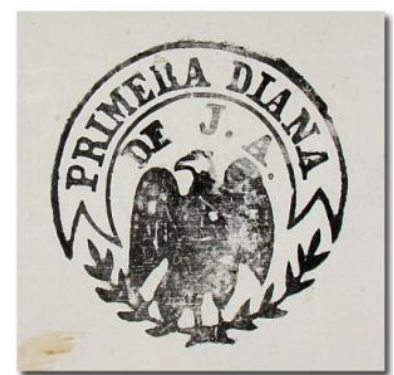

Figura 121 Primera Diana de J. A. Julián Alvarez

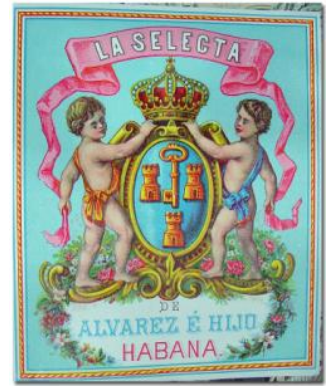

Figura 120 "La selecta" De Alvarez e Hijo. Habana

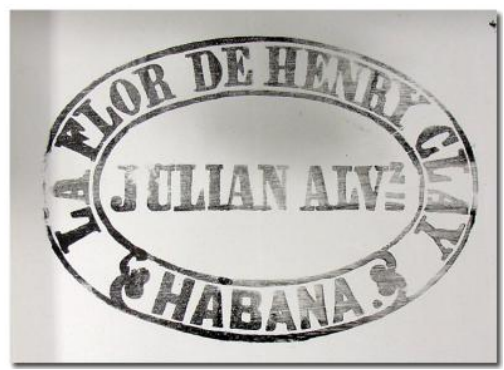

Figura 122 La Flor de Henry Clay. Habana.

Esta fábrica de tabaco obtuvo medallas de oro en las Exposiciones Internacionales de Filadelfia en 1876.

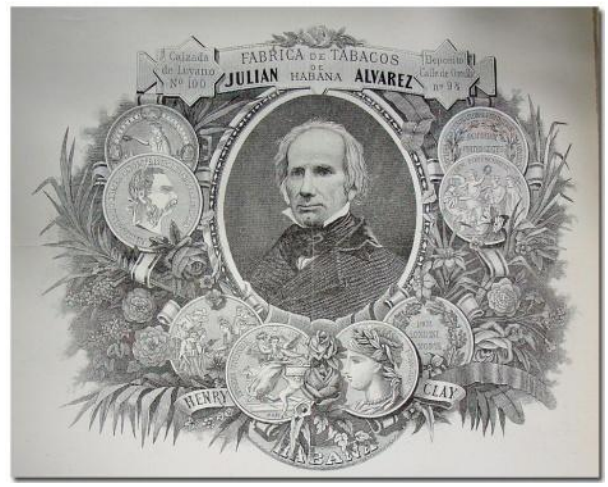

Figura 123 Henry Clay. Fábrica de Tabacos de Habana. Clz. Luyano No 100 Depósito Calle Oradly No 9 1/2 Julián Álvarez 


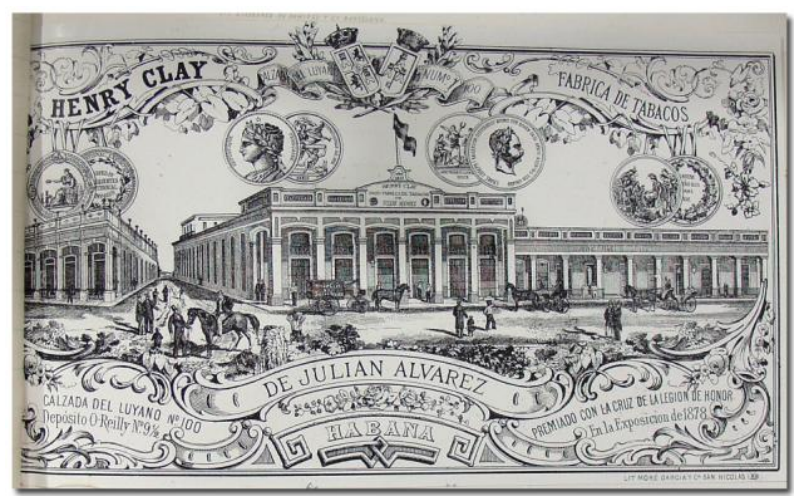

Figura 124 Henry Clay. Fábrica de Tabacos de Habana. Clz. Luyano No 100 Depósito Calle Oradly No 9 11/2 Julián Álvarez.

Premiado con la Cruz de la Legión de Honor en la Exposición de 1878. Lit Moré García y C - San Nicolás 124

\section{También fue premiada en París en 1878 con la marca "Primera Diana"}
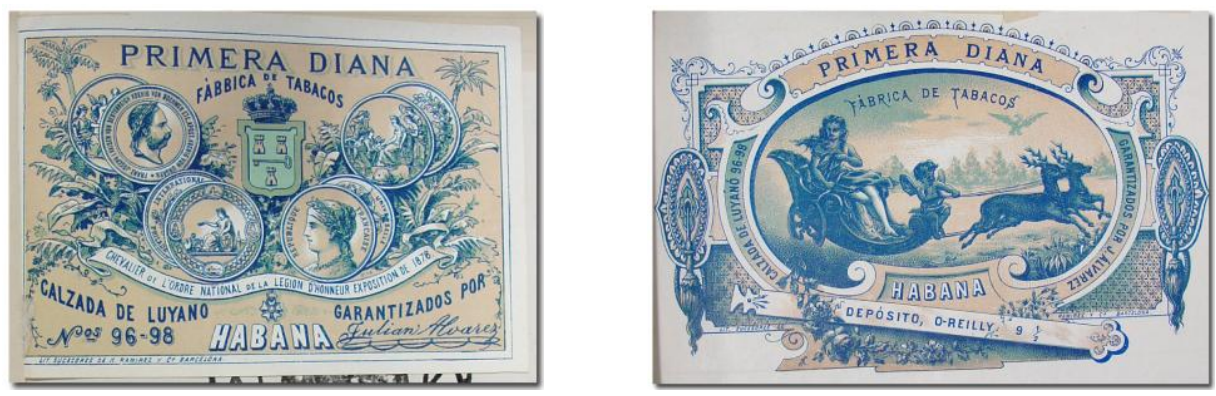

Figs. 125 y 126 Primera Diana Fábrica de Tabacos. Calzada de Luyano Nos 96-98 Garantizados por Julián Álvarez. Habana

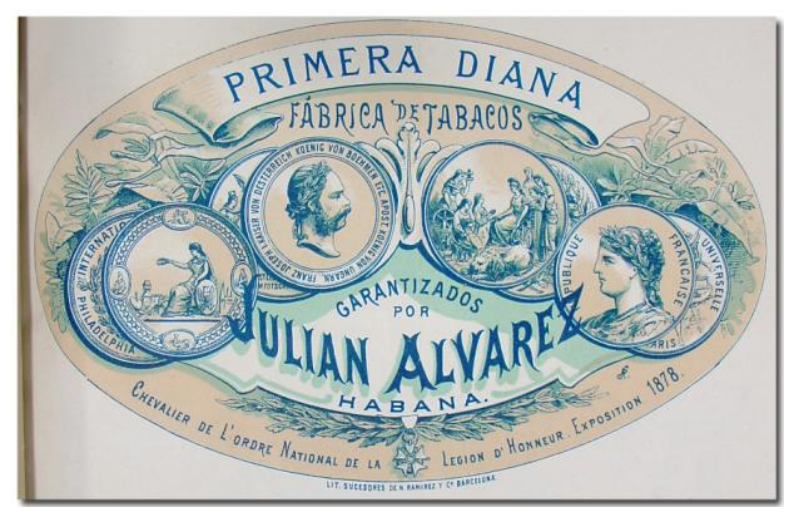

Figura 127 Primera Diana. Fábrica de Tabacos. Garantizados por Julián Älvarez. Habana. Chavalier de LÓdre National de la Legion d'Honneur. Exposition 1878 Lit. Sucesores de Ramírez y Coㅡ Barcelona 


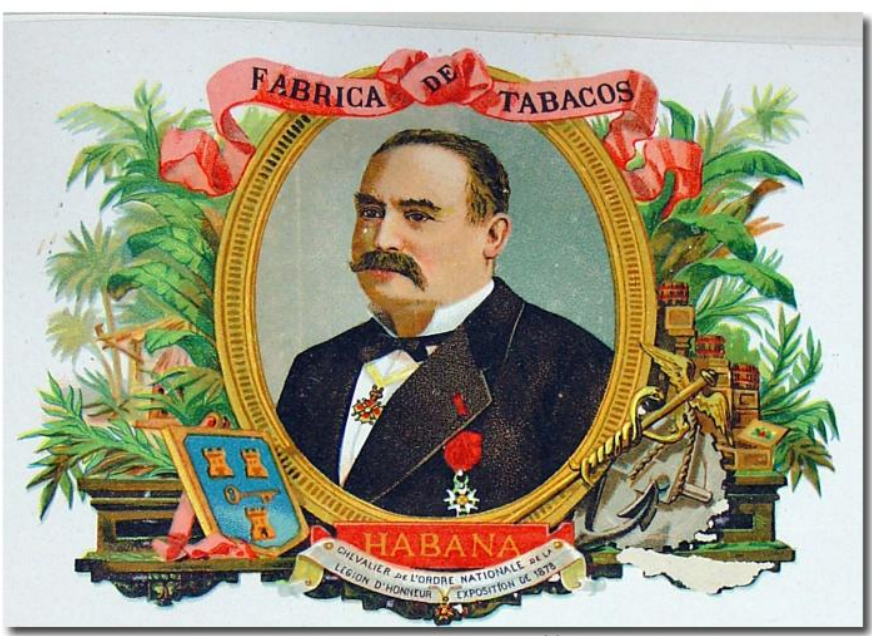

Figura 128 Don Julián Álvarez ${ }^{94}$. HABANA.

Chavalier de L'Ordre Nationale de la Legion D'Honneur Exposition de 1878

El uso de la vitola es un anillo para cigarro o sortija de papel que rodea a los a modo de marca de fábrica su uso data de mediados del siglo XIX, cuando repuntó la litografía y se arraigaba el consumo de los cigarros.

Las habilitaciones ${ }^{95}$ se colocaban en distintos lugares de las cajitas de cedro para adornarlas o sellarlas. En la figura 129 observamos la etiqueta que se colocaba en la parte exterior de la tapa superior de la caja ó estuche, incluye el nombre de la fábrica y del fabricante: "La Corola" de B. Prida; la dirección del fabricante: Callejón de Santa Inés No 12; el lugar de origen: Veracruz; el precio del producto: 8 centavos y la compañía litográfica que realizó la etiqueta: Moreau y Cía.

\footnotetext{
${ }^{94}$ Florencio Giménez Caballero Op. Cit. p 368. La imagen de la etiqueta concuerda con la que se presenta en esta obra y corresponde al dueño de la fábrica Julián Álvarez.

${ }^{95}$ Ibidem p. 53
} 


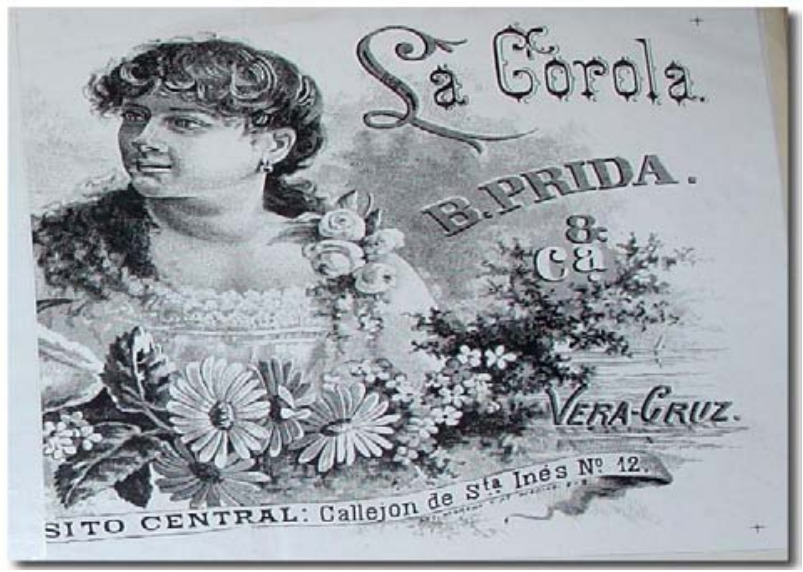

Figura 129 Prida y Ca. Marca" La Corola". 8 centavos cajetilla. Depósito central Callejón de Sta. Inés No. 12 Veracruz.

Poco a poco se fueron incluyendo bellas imágenes polícromas de paisajes, alegorías históricas, etc.

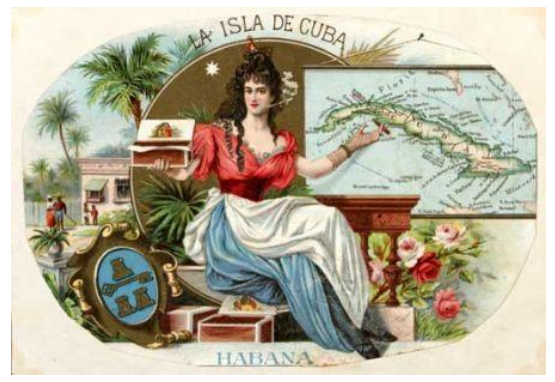

Figura 130 Litografía de caja de puros

http://www.ambasadakube.org.rs/serbian/img/habanos/habanos1.jpg
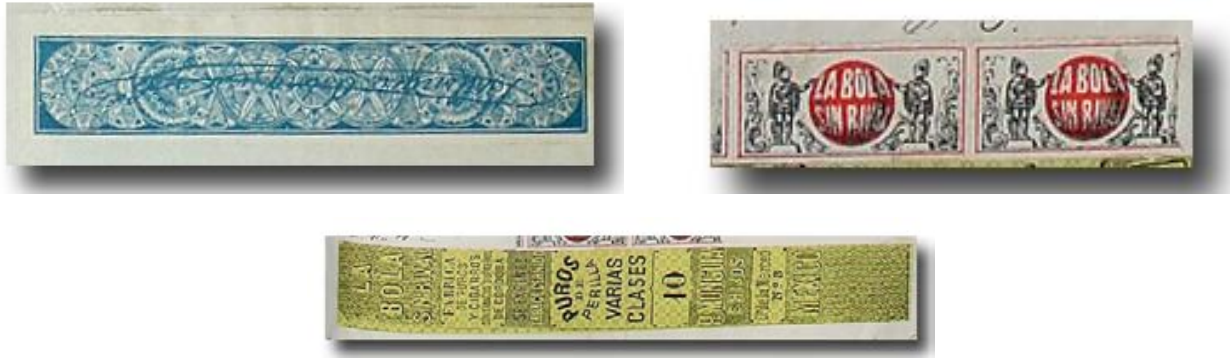

Figs. 131,132 y 133 Ejemplos de sellos de la fábrica La Bola 
Como parte de las habitaciones, el bofetón o bocetón, era una etiqueta que se adhería al estuche por un extremo, algunos no suministraban información al consumidor porque su misión era proteger al producto y evitar que se perdiera o disminuya su aroma y sabor (Fig. 131, 132 y 133). En tanto la papeleta o seña se situaba a un costado del estuche (Fig. 134) sobre la tapa superior e inferior o fondo su función es de cierre o sello y suministraba información del fabricante y el producto.

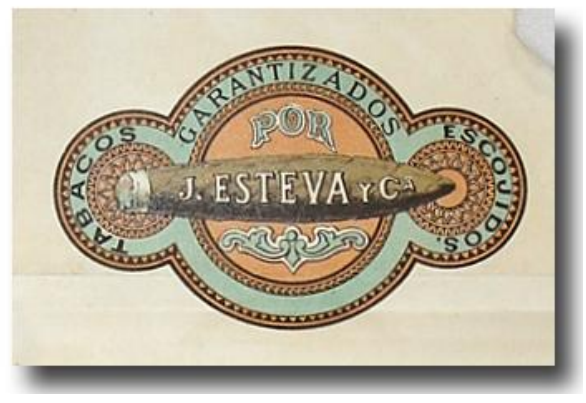

Figura 134 Tabacos garantizados escogidos J. Esteva y Cía.

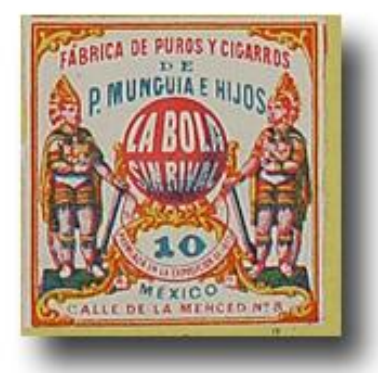

Figura135 Fábrica de puros y cigarros de P. Munguía e Hijos La Bola sin Rival 10 México, Calle de la Merced No 8

Tapaclavos o contraseña es una etiqueta pequeñita, se coloca sobre el clavo que une la tapa del estuche al lateral del frente para ocultarlo. Para abrir el estuche es necesario romperla (Fig.135)

En algunas etiquetas se reportaban los premios que las fábricas habían obtenido en las exposiciones universales, este es el caso de la etiqueta que es parte del juego de habilitaciones de la fábrica de Tabacos Supremos de Remigio Noriega impresas en la Litográfica del Borrego en México (136). 


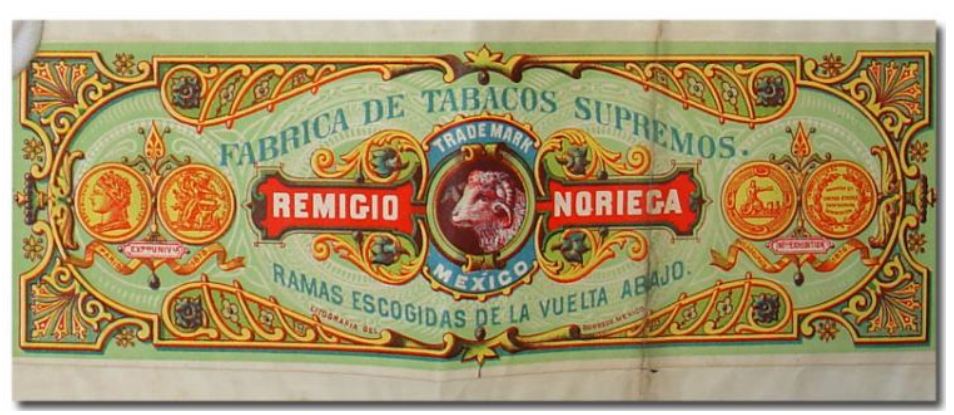

Figura 136 Papeleta de la Fábrica de tabacos Supremos. Remigio Noriega.1885

Cada etiqueta o sello tenía una función particular, al juego de habilitaciones se les denominaba: "filete" y con esto surgió la figura y oficio de "fileteador" que era la persona que adornaba las cajas y cajones con las habilitaciones ${ }^{96}$. Una vez colocados los anillos alrededor de los puros, y éstos en las cajitas de cedro con sus respectivas "habilitaciones", para transportarlas se metían adentro de cajones de madera de pino.

Giménez Caballero presenta una breve descripción y algunos datos sobre los personajes que se han ha dibujado en cada una de las 100 vitolas de su obra. La figura 137) representa al último emperador azteca: "Cuauhtemoc", esta vitola" fue diseñada para la fábrica de García M.P. e hijos

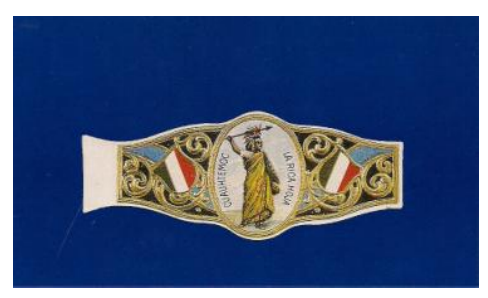

Figura137 Vitola "Cuauhtemoc"

\footnotetext{
${ }^{96}$ Florencio Giménez Caballero Op. Cit. Pp 50-51

${ }^{97}$ Ibid. p 85
} 
Los hermanos Rafael y Manuel P. García llegaron a México en 1876, y eran grandes conocedores del tabaco, fundaron la fábrica "EI destino" en San Andrés Tuxtla, Veracruz, México, además registraron otras marcas de cigarros y puros: "La Violeta", "La Sin Rival" y "El Brillante Negro", posteriormente se construyó otra fábrica en Orizaba, en el estado de Veracruz en donde crearon y explotaron "La Violeta" con otra razón social M.P. García e hijos, Sucesores.

"La rica hoja" vitola 67 (Fig.138) tiene la leyenda: Regalía "La buena hoja" de M.P. García e Hijos. Fue una marca mexicana del año 1888 era el único propietario de "La Rica Hoja" y vemos un numero de registro 144. Menciona Giménez que tal vez esta empresa imprimía sus vitolas en las firmas litográficas alemanas de G.K. o la de Herman Schöt y en las americanas de Steffens Jones \& $\mathrm{C}^{\circ}$ en Nueva York y representante para América de la litográfica alemana Wilhem Wefers con sede en Grefeld (Alemania). Para 1891 o 1897 ya era costumbre numerar las anillas.

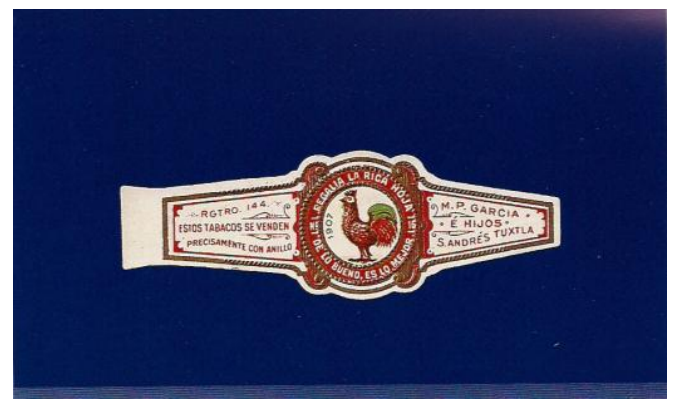

Figura 138 Regalía "La Rica Hoja" de lo bueno lo mejor. Registro 144. Estos tabacos de venden preferentemente con anillo. H.P García e Hijos. San Andrés Tuxtla

Después fue registrada la marca "El destino" se observa en la etiqueta Manuel P. García como dueño de la fábrica de tabacos en 
San Andrés Tuxtla y el único depósito a nombre de $\mathrm{C}$. Benito y $\mathrm{C}^{\mathrm{a}}$ en Veracruz.(Figs 139,140,141 y 142)

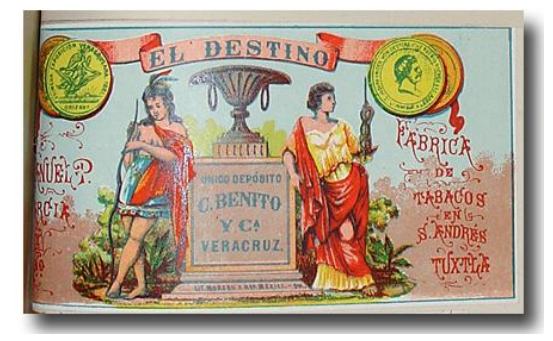

Figura139 "El Destino". Manuel P. García.

Fábrica de Tabacos. San Andrés Tuxtla
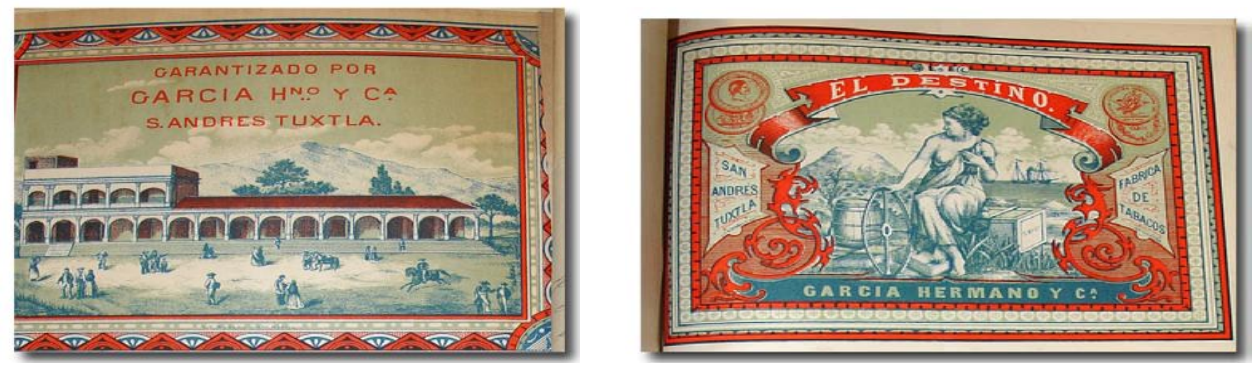

Figura 140 García Hno. y Ca. San Andrés Tuxtla Figura141 "El Destino" Gran Fábrica de Tabacos y cigarros de M. P. García y Hnos. S. Andrés Tuxtla

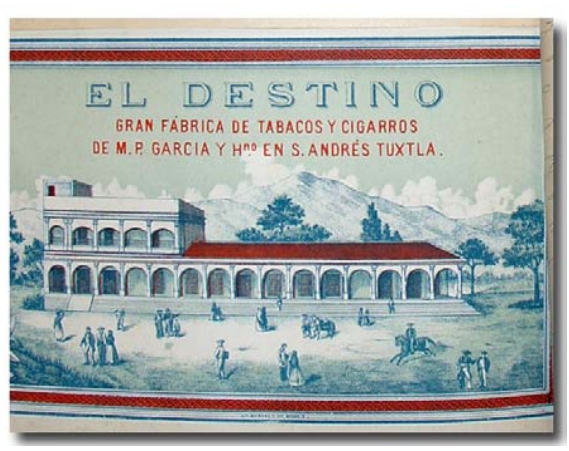

Figura142 "El Destino" Gran Fábrica de Tabacos y cigarros De M. P. García y Hnos. S. Andrés Tuxtla 
En la obra de Giménez y López, las vitolas números $65^{98}$ (fig. 143) $66^{99}$ (realizada en la fábrica de H. UPMANN) (fig. 144) y la $67^{100}$ (fig.145) presentan el retrato de Porfirio Díaz, a lo largo de nuestra investigación conoceremos la historia de la litografía en México durante el último tercio del siglo XIX cuando gobernaba a México el general Díaz quien ostentó el poder de 1881 hasta 1911 cuando fue exiliado a París. En el caso de la vitola número $65^{101}$ (fig.143) los autores de Cien Anillas de Calidad consideran que posiblemente fue impresa en alguna litográfica estadounidense o alemana cuyas sucursales se instalaron en Cuba: Gebr. Kingenberg (G.K) o la de Hermann Schött (H.S.).

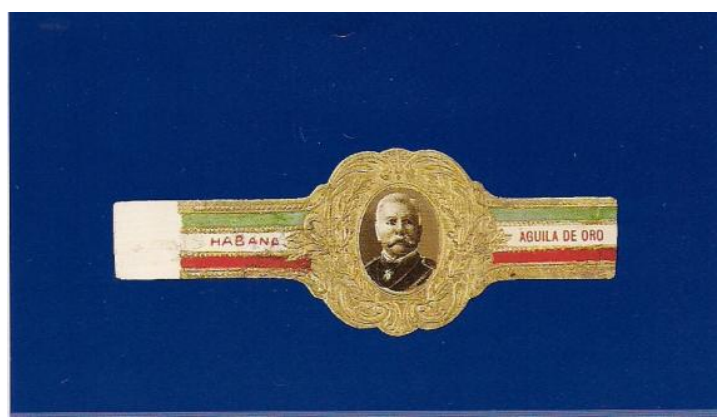

Figura 143 Habana "Águila de Oro"

En el caso de las vitolas $66^{102}$ (Fig.144) y en la $67^{103}$ (Fig.145) se indica la marca de fábrica mexicana de Agustín Blanco, la litográfica pudo ser la de Hupmann o Holman Schött respectivamente.

\footnotetext{
${ }^{98}$ Ibid. p. 217

${ }^{99}$ Ibid. p. 221

${ }^{100}$ Ibid. p. 223

${ }^{101}$ Ibid. p. 217

${ }^{102}$ Ibid. p. 221
} 


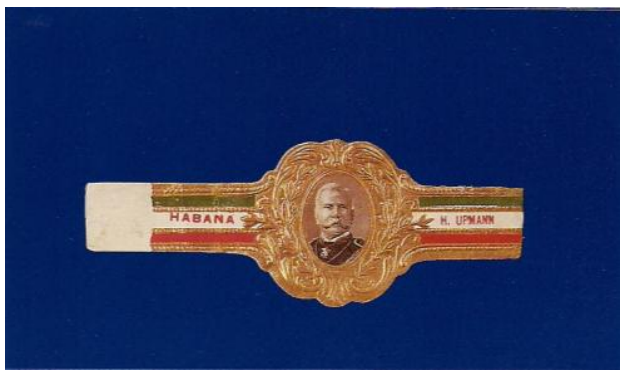

Figura144 "Porfirio Díaz" Habana. H. Upmann

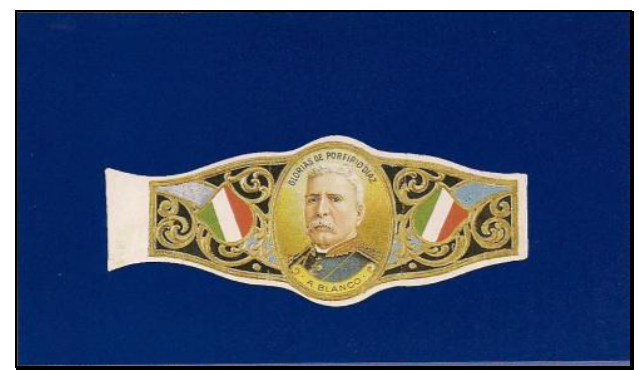

Figura145 “Glorias de Porfirio Díaz”. A. Blanco

La vitola $68^{104}$ (Fig.146) se refiere a la fábrica de Carlos González Montes de Oca, mexicano, jalisciense nacido en 1846, se unió al grupo revolucionario de la Laguna, Matamoros, Viesca para atacar a las fuerzas francesas que combatían a Benito Juárez. Carlos González Montes de Oca acompañado de 50 hombres fue enviado a entregar un documento a Juárez. Debido al combate con las tropas francesas solamente llegaron 25 hombres, entre los cuales estaba Carlos González quien pudo lograr el cometido vitola 69 ${ }^{105}$. Años más tarde González se unió a las tropas de Porfirio Díaz en la Batalla de la Noria y después en el plan de Tuxtepec y fue nombrado Coronel. Posteriormente se retiró del ejército para dedicarse a la agricultura, logró amasar una gran fortuna con la que propició el crecimiento económico de la ciudad de Torreón, Coahuila, construyó dos hoteles, y donó los terrenos para la construcción de la estación ferroviaria además junto con tres socios construyó la Plaza de Toros de Torreón según la línea de la plaza de Madrid. González viajó a Barcelona en donde murió en 1917. Consideran los autores, que el diseño e impresión de la vitola corresponden con las características de los talleres litográficos cubanos.

\footnotetext{
${ }^{103}$ Ibid. p. 223

${ }^{104}$ Ibid. p. 225

${ }^{105}$ Ibid. p. 229
} 


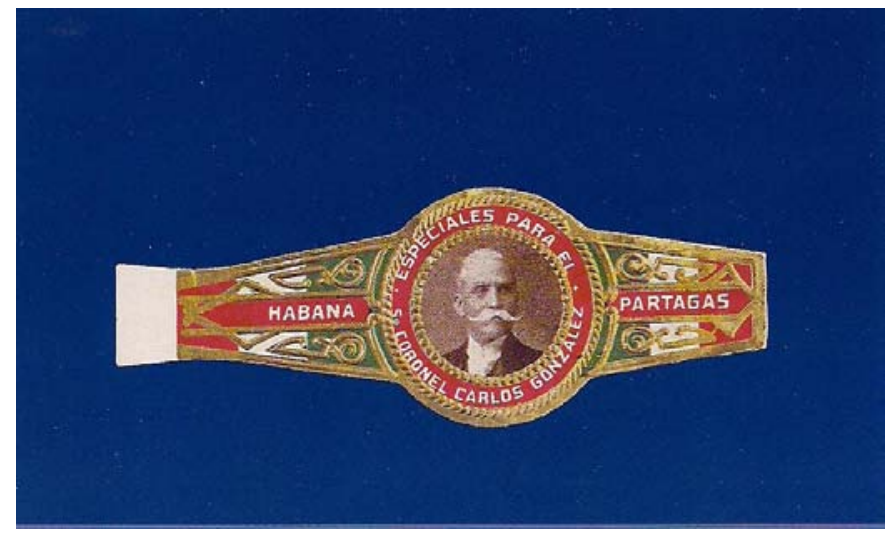

Figura 146 "Especiales para el Coronel Carlos González" Habana, Partagas

En la vitola $70^{106}$ (Fig. 147) emitida en 1910, podemos observar a tres personajes que fueron importantes para la historia de México: al centro Miguel Hidalgo y Costilla, sacerdote, ordenado en 1779 dio el "grito de independencia" en Dolores Hidalgo en 1810 y fue fusilado en 1811; Benito Juárez quien dictó las "Leyes de Reforma" con las que se destituyeron los bienes y privilegios al clero en 1857 y Porfirio Díaz quien durante sus 30 años de gobierno se estableció la llamada "paz profiriana" periodo en que México se presentaría ante el mundo como un país civilizado y libre, apto para recibir a los inversionistas extranjeros. Esta vitola pertenece a la empresa A. Pastor y Compañía y las iniciales S.J.B. se refieren a la localidad mexicana de San Juan Bautista en donde estaba ubicada la fábrica. 


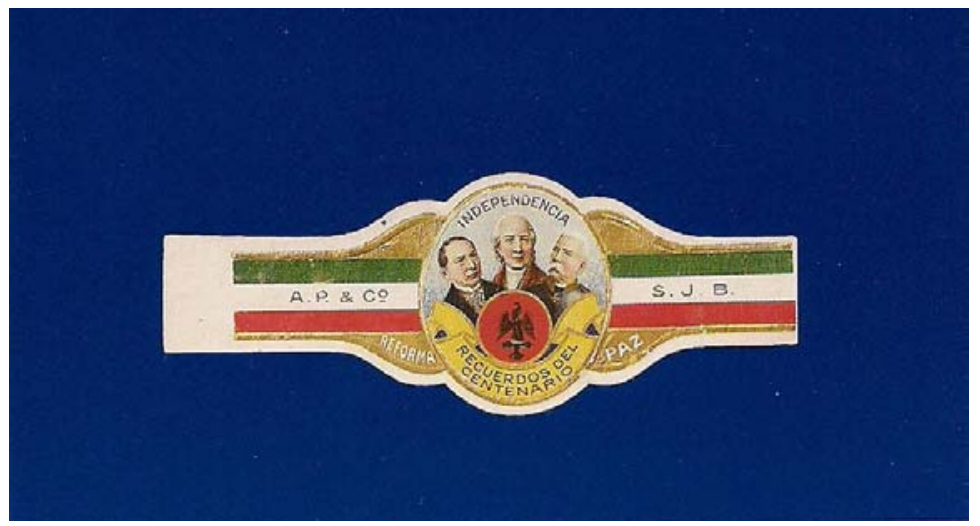

Figura 147 "Recuerdos del Centenario" Independencia, Reforma, Paz. A.P. \& $\stackrel{0}{\circ}$ S.J.B

Aún cuando resultan muy interesantes, estas vitolas no fueron impresas en talleres mexicanos, los dueños de las tabacaleras las mandaban imprimir en Cuba donde se habían instalado empresarios alemanes e ingleses quienes en sus litográficas utilizaban los más delicados diseños y trabajos de pan de oro.

Encontramos algunas vitolas (Fig. 148) realizadas por la fábrica de puros La Violeta, de Orizaba para la conmemoración del bicentenario de la Independencia ${ }^{107}$ en las que están dibujados los retratos de mexicanos ilustres: Hidalgo, Allende, Aldama Mina, Morelos, Ocampo, Díaz, etc.

\footnotetext{
${ }^{107}$ Fotografía tomada de: Florescano Francisco. Imágenes de la Patria. México, Taurus, 2005 p 236
} 


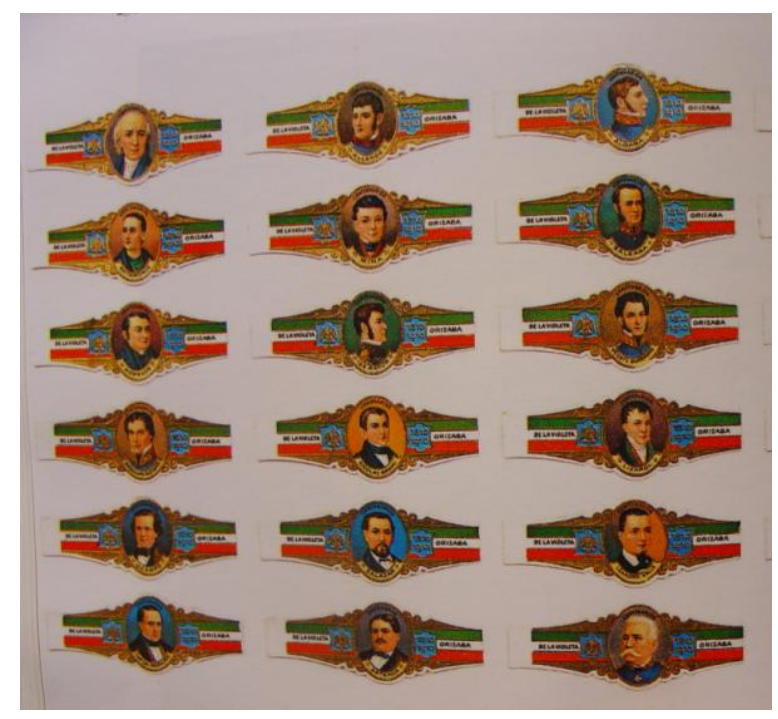

Figura 148 Vitolas de la Fábrica de puros "La Violeta”, Orizaba, 1910.

Al final del siglo XIX Luciano N. Grobet de ascendencia alemana se estableció en San Andrés Tuxtla registrando la marca "La Vencedora" (Fig.149). Tenía un estanco para comercializar sus productos en la Calle del Espíritu Santo No 7 en la ciudad de México. Al irse a España, continuó con la empresa su hijo L. Grobet que fundó una sociedad mercantil L. Grobet $C^{a}$ y Sucs. Con las marcas "La Preferida" y "La Favorita".

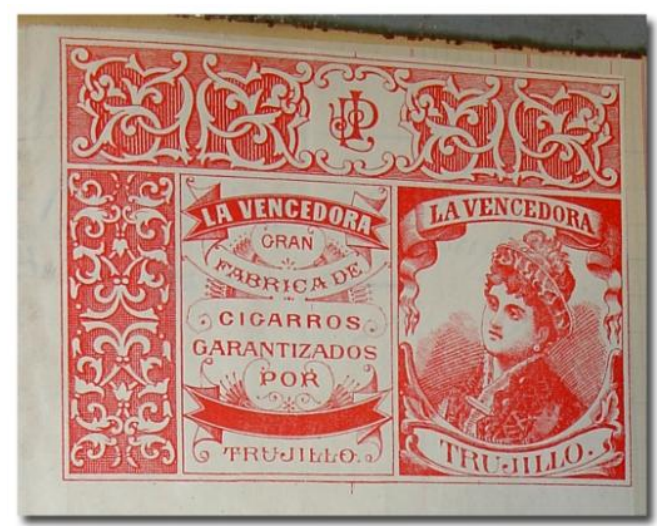

Figura 149 "La Vencedora” Gran fábrica de cigarros. Garantizados por Trujillo 


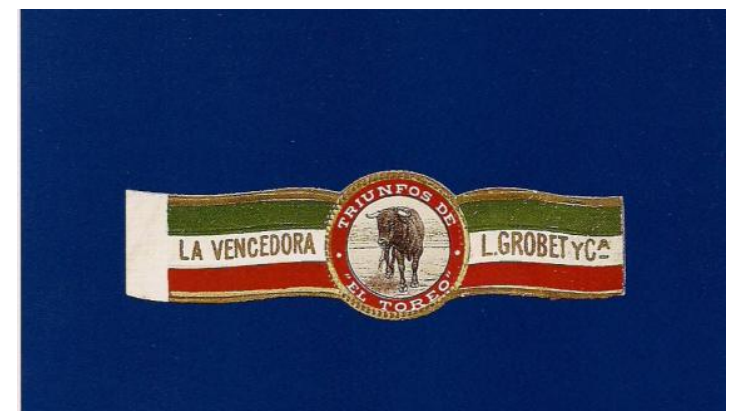

Figura 150 Vitola Toro de Lidia. Fábrica La Vencedora. L Grobet y C C $^{\underline{a}}$

Sobre el tema taurino encontramos tres etiquetas: Ignacio Álvarez era el dueño de la fábrica de tabaco ubicada en San Andrés Tuxtla y tenía su depósito en la calle de Coliseo 25. "El Gordito" (fig. 151) era una nueva marca, la etiqueta tiene el perfil del torero Antonio Carmona Luque "El gordito" quien el 8 de junio de 1862 tomó la alternativa teniendo como padrino a su hermano José Carmona Luque $^{108}$, con la ganadería de Romero Balmaseda en la plaza de toros de los Tejares en Córdoba, su confirmación fue en Madrid el 5 de abril de 1863, de manos de Francisco Arjona Herrera "Cúchares". Carmona Luque tuvo una muy particular visión de la Fiesta Nacional, la concebía como un espectáculo y no dudaba en adornarse con numerosas excentricidades que le granjearon la enemistad de numerosos espectadores. Uno de sus más conocidos rivales taurinos fue "El Tato". "El Gordito" falleció en Sevilla el 30 de agosto de 1920.

${ }^{108}$ http://portaltaurino.com/matadores/el_gordito.htm 


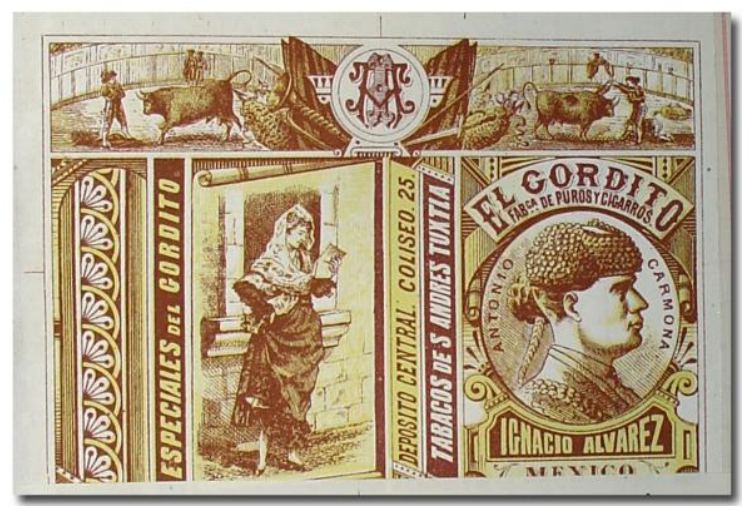

Figura 151 "El Gordito" fábrica de puros y cigarros. Tabacos de San Andrés Tuxtla. De Ignacio Álvarez. Depósito Coliseo 25

Los cigarros de la marca: "El Torero" (figs. 152 y 153) estaban de venta en la tienda Pico de Orizaba ubicada en las calles de Moras y Sepulcros de Sto. Domingo, en la ciudad de México, la casa litográfica fue La Catalana. En la etiqueta dibujaron al lado izquierdo un torero que está a punto de colocar las banderillas en "todo lo alto".

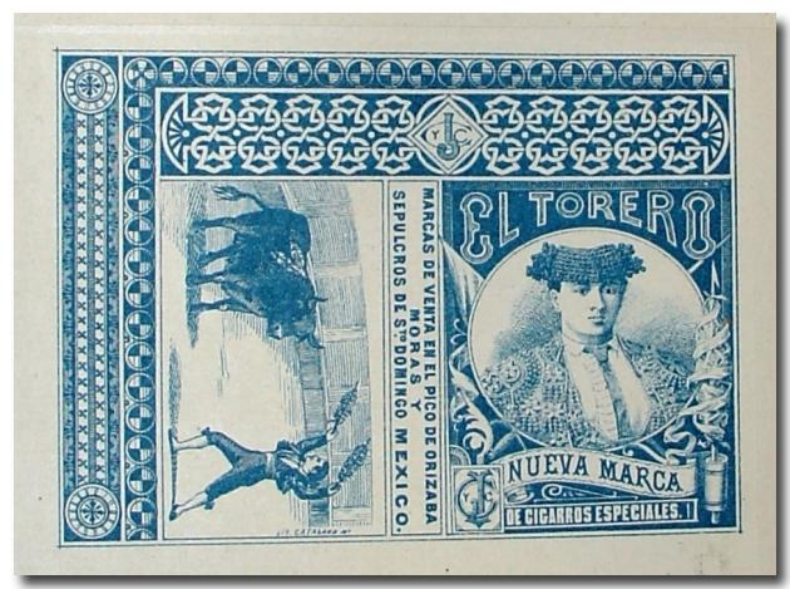

Figura152 "El torero" Marcas de venta en el Pico de Orizava Moras y Sepulcros de Sto. Domingo. México 


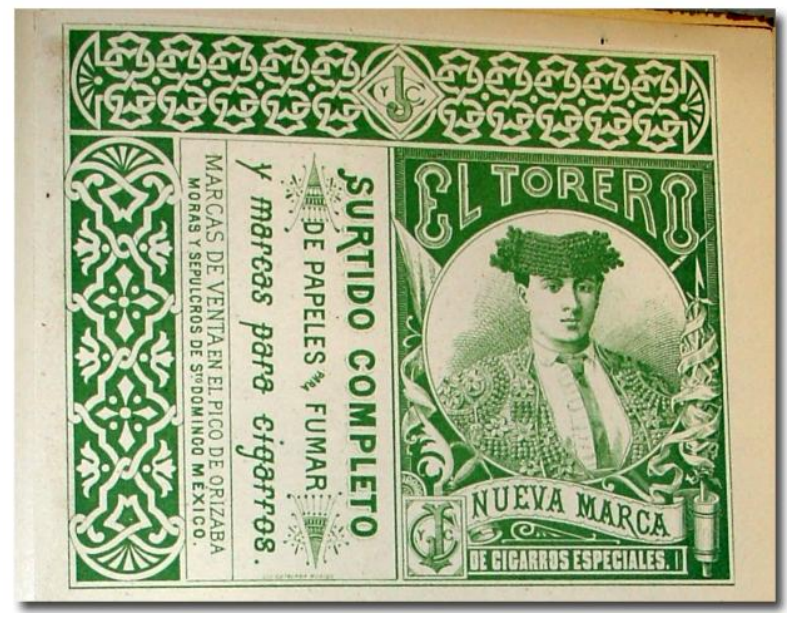

Figura153 "El torero" Marcas de venta en el Pico de Orizava Moras y Sepulcros de Sto. Domingo. México

Otra etiqueta relacionada con las corridas de toros (fig. 154) es de la fábrica de puros y cigarros de Ibargüen y Abasolo ubicada en la Calle de los Migueles no 9. Tenía su depósito central en Flamencos No 1, Tabaquería de la Comuna. La marca "El Lagartijo". Rafael Molina Sánchez ${ }^{109}$, "Lagartijo" considerado el primer "Califa" de Córdoba (1841-1900), tomó la alternativa en Úbeda (1865) y desde entonces su nombre fue obligado en todos los carteles hasta su retirada en 1893.

«Fue más torero que matador. Con la capa, las banderillas y la muleta era insuperable... Hijo legítimo de la escuela sevillana que creara Costillares, sus donaires, jugueteos y filigranas entusiasmaban y enardecían al público hasta un extremo que sólo habiéndolo visto puede creerse... Dio muerte a cinco mil doscientos toros... y no tuvo más que seis cogidas, todas leves» (Natalio Rivas).

«De él se dijo muchos años que se podía pagar con gusto el dinero de la entrada, sólo por verle hacer el paseíllo... Hasta él la lidia había sido lucha, caza; con él empezó a ser un juego artístico con plástica y belleza» (Curro Meloja).

${ }^{109}$ http://www.galeon.com/anilo/toreo/Lagartijo.htm\#Lagartijo 
Incluso Frascuelo, su principal rival en los ruedos, llegó a decir «que el cordobés es el mejor torero que ha parido madre».

Alardeaba de republicanismo, aunque sus votos y los de sus amigos iban a parar a las urnas de los candidatos que patrocinaba Romero Robledo, el gran elector de Cánovas. En 1889, en la primera de las corridas que se celebraron en París con motivo de la Exposición Universal (la de la torre Eiffel), se negó a brindar un toro a la destronada reina Isabel II «porque soy republicano».

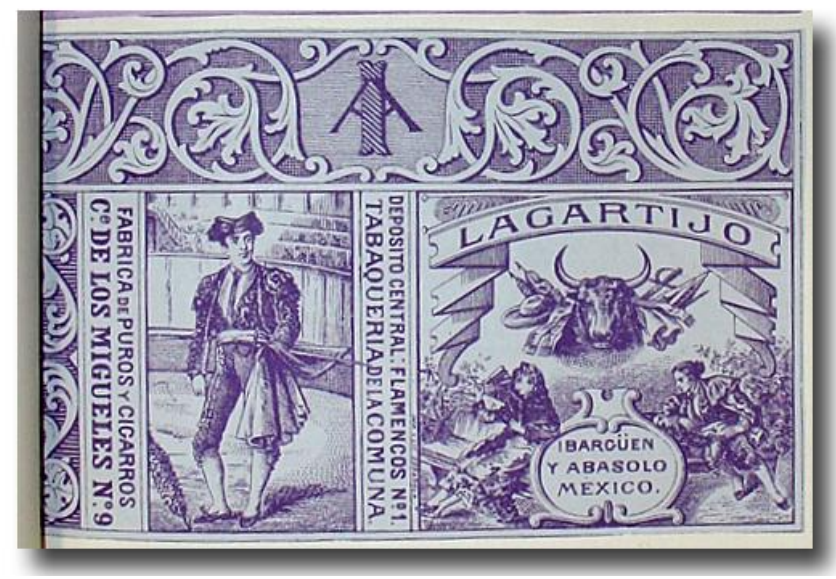

Figura 154 "Lagartijo" Fábrica de puros y cigarros de Ibargüen y Abasolo Calle de los Migueles No 9. Depósito central: Flamencos No 1 Tabaquería de la Comuna. México

La fábrica de cigarros de Eusebio Rojas "La ilusión" también promovía la fiesta brava. En la etiqueta (fig 155) observamos de lado izquierdo al matador dando una estocada al toro. La etiqueta corresponde a la fábrica de puros y cigarros ubicada en la Calle de Belén, Letra K, en la ciudad de Guanajuato, México. 


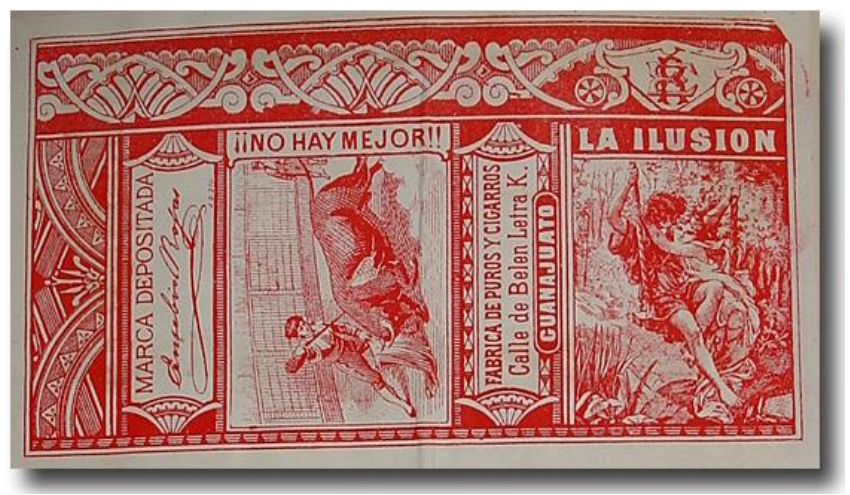

Figura 155. Marca de ilusión. Marca registrada de Eusebio Rojas

La "salida del toro" (Fig.156) fue representada en la etiqueta de la fábrica de tabacos de exportación de González Hnos. "Las Dos Naciones", ubicada en la primera avenida de Grijalva. San Juan Bautista en el Estado de Tabasco.

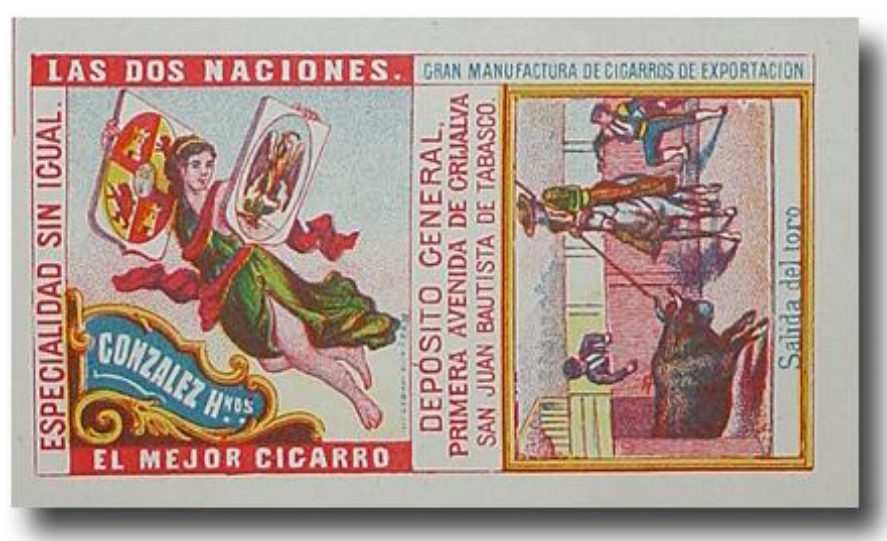

Figura 156 Fábrica de González Hnos. 1aㅗ Av. Grijalva.

San Juan Bautista de Tabasco 
La vitola número $69^{110}$ (Fig. 157) tiene el retrato de Benito Juárez (1806-1872) pertenece a la fábrica de Agustín Blanco y como marca anexa el propietario registró "La Unión Nacional" esta vitola no tiene número de registro. En la vitola puede leerse Glorias de Benito Juárez y la marca de fábrica de A. Blanco, de la misma forma que la 67 esta vitola fue impresa en la litográfica alemana de Hermann Schött (H.S)

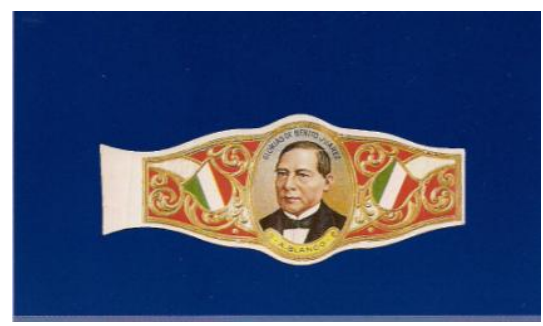

Figura157 "Glorias de Benito Juárez". A. Blanco

Juárez nació en la época en que Miguel Hidalgo y Costilla cuando iniciaba el proceso independentista en México. Cursó estudios en el seminario y se graduó en el área de Derecho. Sus cargos políticos en el Estado de Oaxaca de donde era oriundo, fueron: regidor del ayuntamiento en 1831; diputado local en el congreso de Oaxaca 1833; juez civil y de hacienda en 1841; secretario de comercio en 1846 y gobernador de Oaxaca desde 1847 a 1852, siendo diputado en el congreso local apoyó a Santa Anna pero cuando éste disolvió el congreso. Juárez se exilió a La Habana y luego a Nueva York, regresó a México cuando se proclamó el Plan de Ayutla y formó parte del Consejo de Estado del Gobierno de Juan Álvarez. 
Juárez fue encarcelado por mandato del Presidente Comonfort. Tiempo después fue electo Presidente de la República Mexicana, proclamó las Leyes de Reforma con las que se nacionalizaron los bienes del clero. Juárez se negó a reconocer las deudas contraídas por el Gobierno de Miramón por lo que las tropas inglesas, francesas y españolas enviaron a sus ejércitos a cobrar las cuentas en 1862 Por las negociaciones del Secretario de Relaciones Exteriores Manuel Doblado, se retiraron las fragatas españolas e inglesas, quedando en territorio mexicano los franceses cuya influencia facilitó la imposición de Maximiliano de Habsburgo como emperador. Al salir los franceses de México, el Habsburgo fue aprehendido. Su imagen fue representada en una etiqueta para la fábrica de cigarros La Asturiana (Fig. 158). El ex emperador fue fusilado en el Cerro de las Campanas junto con Miramón y Mejía en 1867.

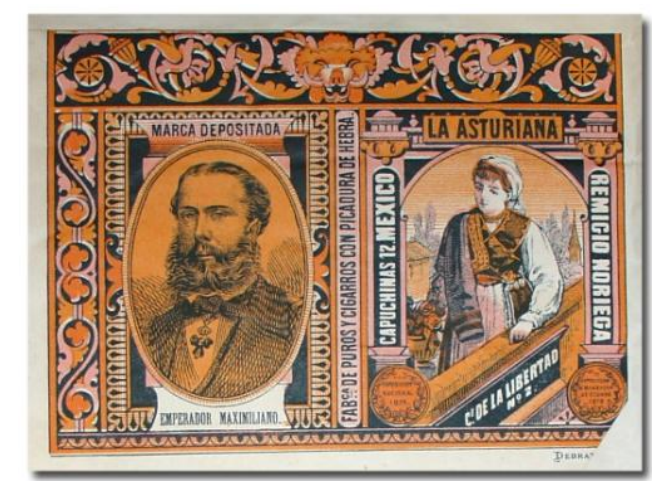

Figura 158 Marca La Asturiana. Remigio Noriega

Entre los años 1850 y 1865 se inicia la época de reproducción de las medallas con las que habían sido premiados algunos productos, en un principio eran implementaciones sencillas (Fig. 159 y 160), pero años más tarde se utilizaría en las medallas y adornos el conocido "pan de oro". 


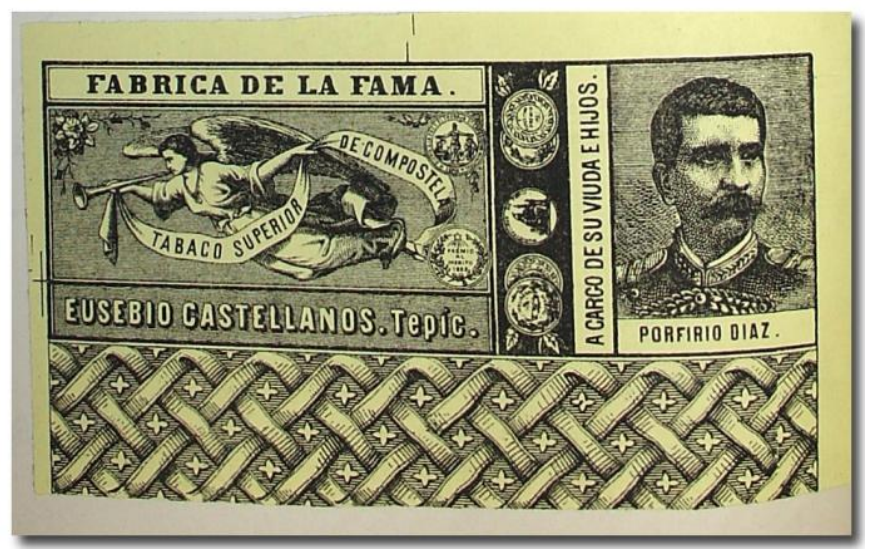

Figura 159 Fábrica de la Fama. "Porfirio Díaz" Tabaco superior de Compostela Eusebio Castellanos. Tepic A cargo de su viuda e hijos.

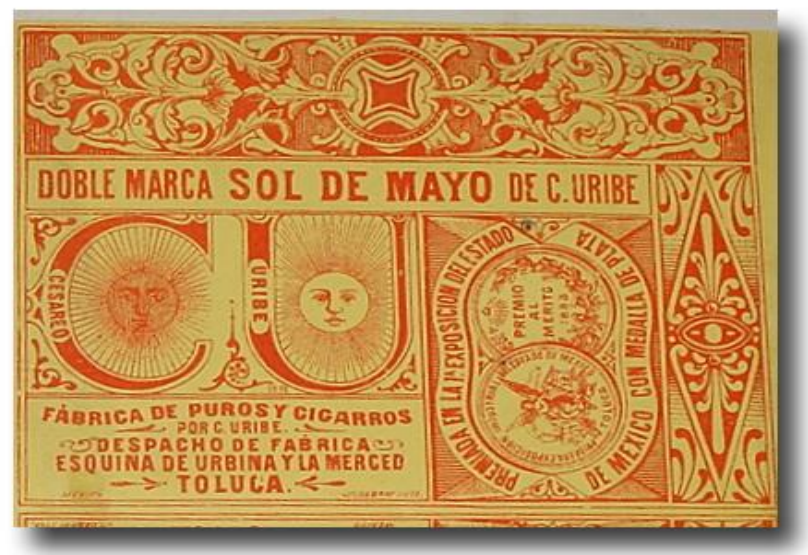

Figura 160 Doble marca Sol de Mayo de C. Uribe. Fábrica de puros y Cigarros. Esquina Urbina y la Merced, Toluca.

Premiada en la exposición del Estado de México, con medalla de plata.

No solamente se establecieron en México fabricantes cubanos, algunos españoles también vieron en México un lugar de prosperidad industrial, y también la capacidad para poder exportar los productos al extranjero. José Fuente de origen español era dueño de la fábrica "Unión" se estableció en Veracruz, en donde poseía casi cuatro millones de metros cuadrados de terreno donde producía 
40,000 arrobas de "Tabaco supremo" y fabricaba al mes 1,000,000 de puros muy bien cotizados para una firma inglesa que los distribuía en Alemania, Rusia e Inglaterra. Su marca publicitada en litografías tenía un tinte político y humorístico los más caros eran "Excepcionales" "Celestiales", "Regalía Especial", "Porfiristas", "Banqueros". "Gonzalistas", "Ricos Comerciantes", "Enriquistas", "Entre Actos" y otros.

Finqueros como Crisanto Pérez Noriega, español, había aprendido el oficio del tabaco en Cuba. Llegó a México con suficiente dinero para establecer junto con el cosechero Francisco de la Peña una fábrica en el Estado de Morelos donde se publicitaban las afamada marcas "La Flor de Xochitengo", "El fuerte de Morelos" y “Jesús H. Preciado". También se establecieron otras fábricas como "El Destino" de García Hermanos y Cía. (Fig.161) "La Favorita" de Rodríguez Miravete; "La Universal” de Luis G. Carrión y Cía.

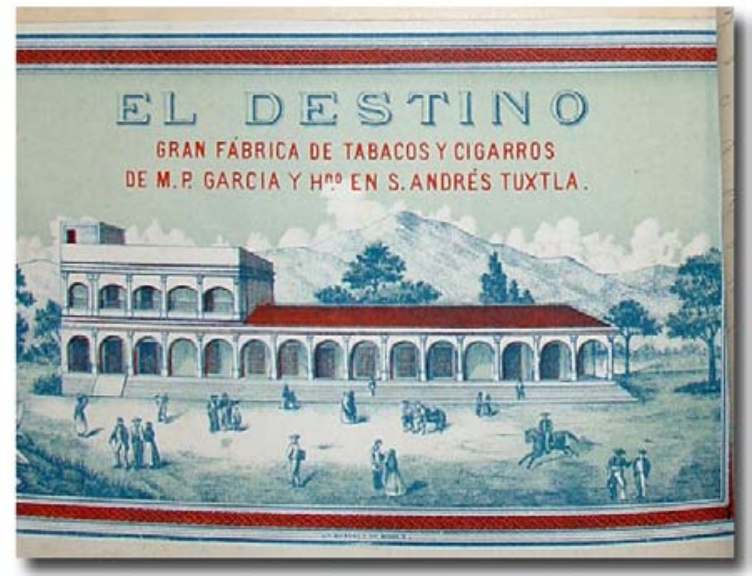

Figura 161 "El destino" Gran fábrica de cigarros M.P. García Hno.

Lit ${ }^{\circ}$ Moreau y Cía. 1884

Pero la automatización en la forja del tabaco no se hizo esperar, Ernesto Pugibet instaló su fábrica de puros y cigarros "El 
BUEN TONO" a fines del siglo XIX y modernizó el proceso adquiriendo unas máquinas que engargolaban los cigarrillos en lugar de pegarlos- Como era un industrial próspero decidió que en lugar de gastar una cantidad fuerte de dinero por el diseño e impresión de las etiquetas, destinaría un lugar especial dentro de la fábrica con todo lo necesario para equipar su taller litográfico en donde se harían etiquetas, cuentos, ideogramas y otras imágenes para publicitar sus productos.(Fig. 162 y 163)

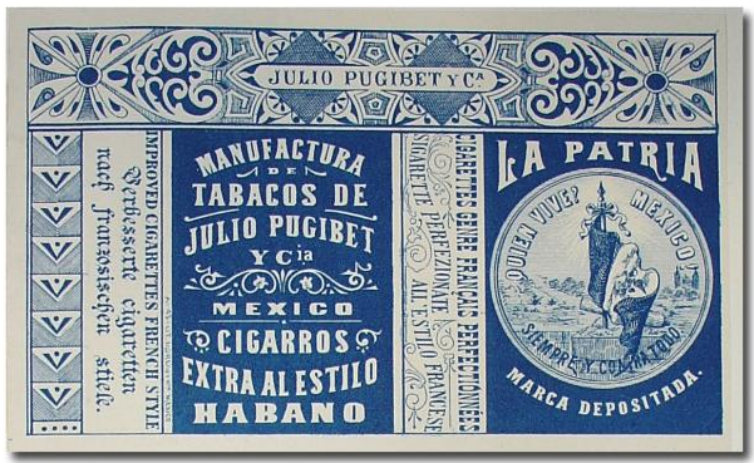

Figura 162 "La Patria” ¿Quién vive? México, Siempre contra todo. Marca depositada. Julio Pugibet y Ca. Manufactura de tabacos de Julio Pugibet y Cía. México. Cigarros Extra al estilo habano. Cigarettes genre francais perfeccionnées Cigarette perfezionate all estilo francese

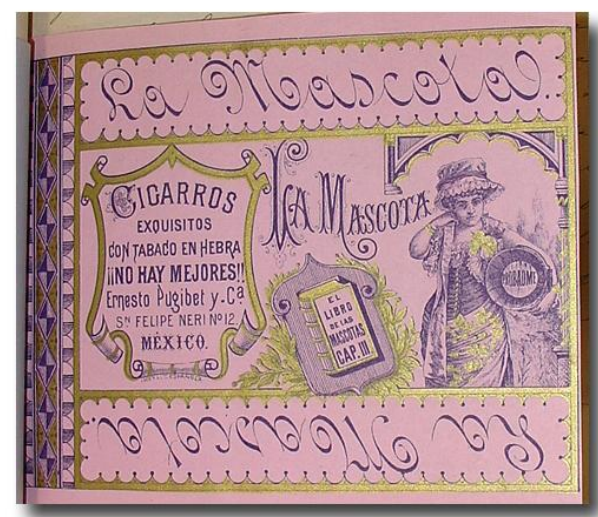

Figura 163 "La Mascota" Cigarros exquisitos con tabaco en hebra ¡No hay mejores! Ernesto Pugibet y Cía. Sn Felipe Neri No 12 México El libro de las mascotas Cap. III 
En las historietas aparecían personajes como "Ranilla" y "Fradiábolo". José Guadalupe Posada, Manuel Manilla, Urrutia y otros grabadores destacados participaron en el "Buen Tono" y los periódicos de la época hacían gala de muy buenos grabados que promovían las tabacaleras para publicitar sus productos.

Nos percatamos que al final del siglo XIX y principio del XX fumar era una costumbre que se generalizó, se produjeron en México país grandes cargamentos de tabaco que fueron exportados a todo el mundo... el consumo del producto no cesaba. A la par que el tabaco, con el desarrollo de la técnica litográfica surgieron talleres que además de imprimir textos hacían litografías comerciales, artistas como Urrieta, Casimiro Castro, además de participar en los que se establecieron dentro de las fábricas, abrieron sus propios en donde diseñaban y litografiaban las etiquetas por encargo. La producción de tabaco y su publicitación hicieron que la competencia entre las fábricas aumentara. Ahora ya no se compraba solamente el forjado o el tipo de tabaco, también se adquiría una marca.

Para hacer ameno e interesante comprar cigarrillos se pensó en dibujar (Fig. 164, 165,166) en las cajetillas de cigarros logogrifos, tal vez mientras fumaban y quemaban el papel del cigarro, algunas personas disfrutaban tratando de descifrarlos, sin embargo la gente del pueblo, que en gran porcentaje era analfabeta, no podía hacerlo. 


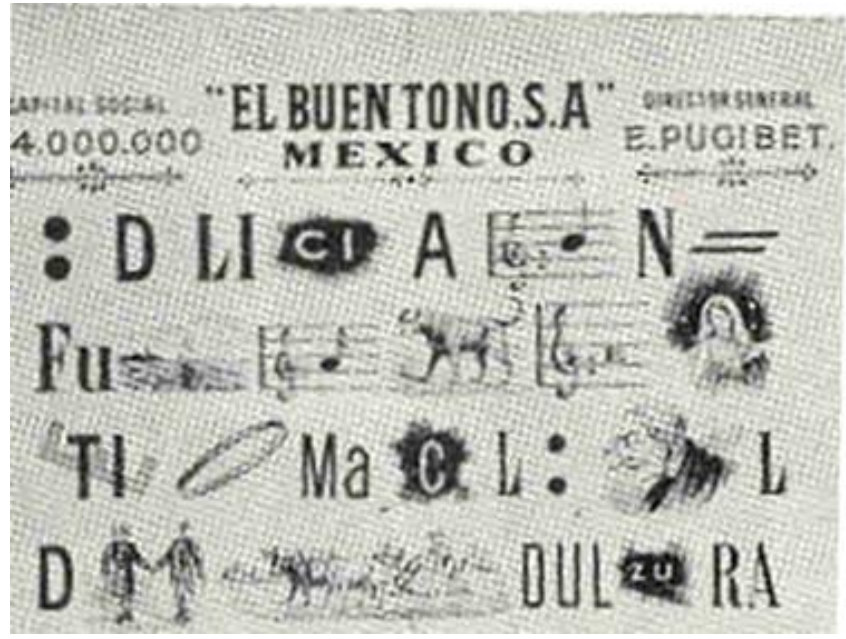

Figura 164 Logogrifo de Urrutia de época anterior a las historietas.

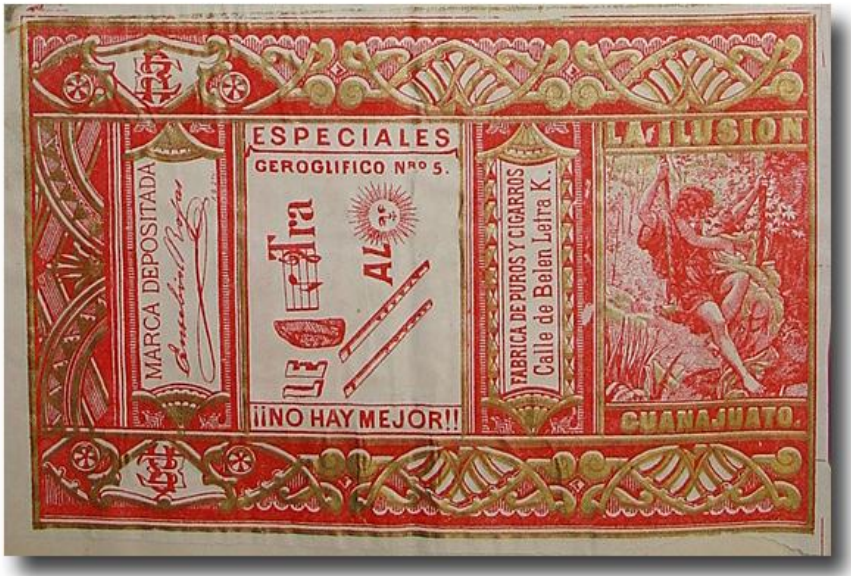

Figura 165 "La ilusión” Especiales Jeroglífico No 5 ¡No hay mejor! Eusebio Rojas. Fábrica de Puros y Cigarros. Calle de Belén Letra K Marca depositada. Guanajuato

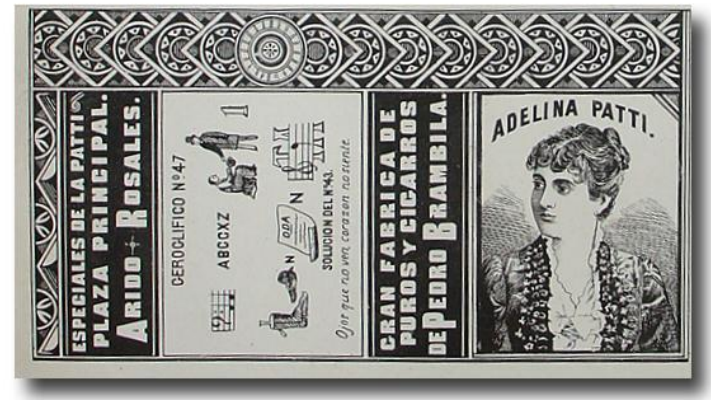

Figura 166 "Adelina Patti" Especiales de la Patti. Plaza principal. Arido Rosales Jeroglífico no 47 Gran Fábrica de puros y cigarros de Pedro Brambila 
Los empresarios sabían que era necesario hacer agradable la adquisición de los productos del tabaco, no solamente por el contenido, también se consideraron importantes el tipo de etiquetas y la publicidad, al mismo tiempo aparecieron algunas historietas breves como la de Genoveva de Bramante que seguramente fue copiada de estampas de Espinal. Tal vez estas fueron antecedente de los comics.

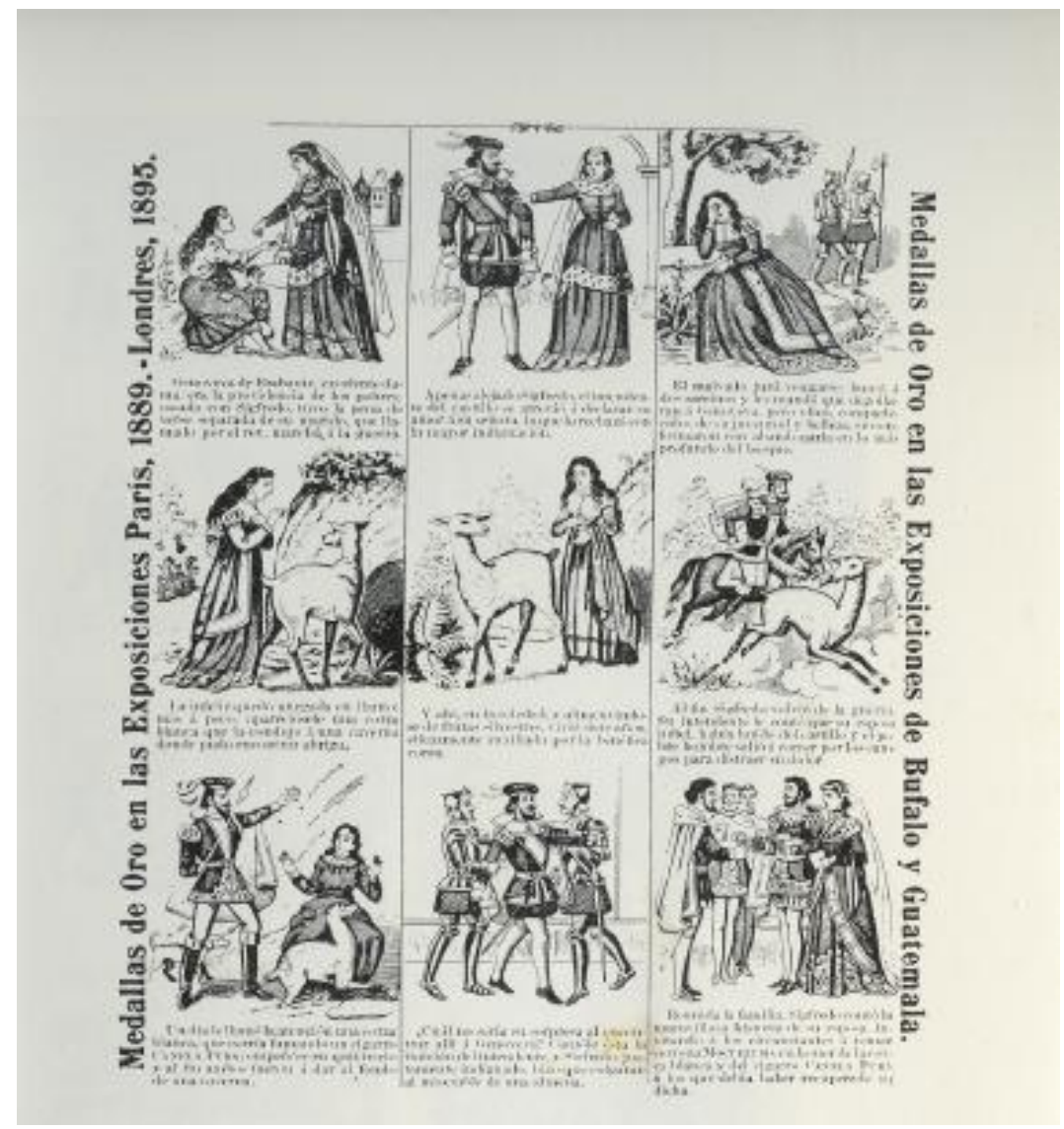

Figura 167 "Genoveva de Bramante". Historieta copiada por Urrutia de alguna estampa de Espinal (lado izquierdo) 


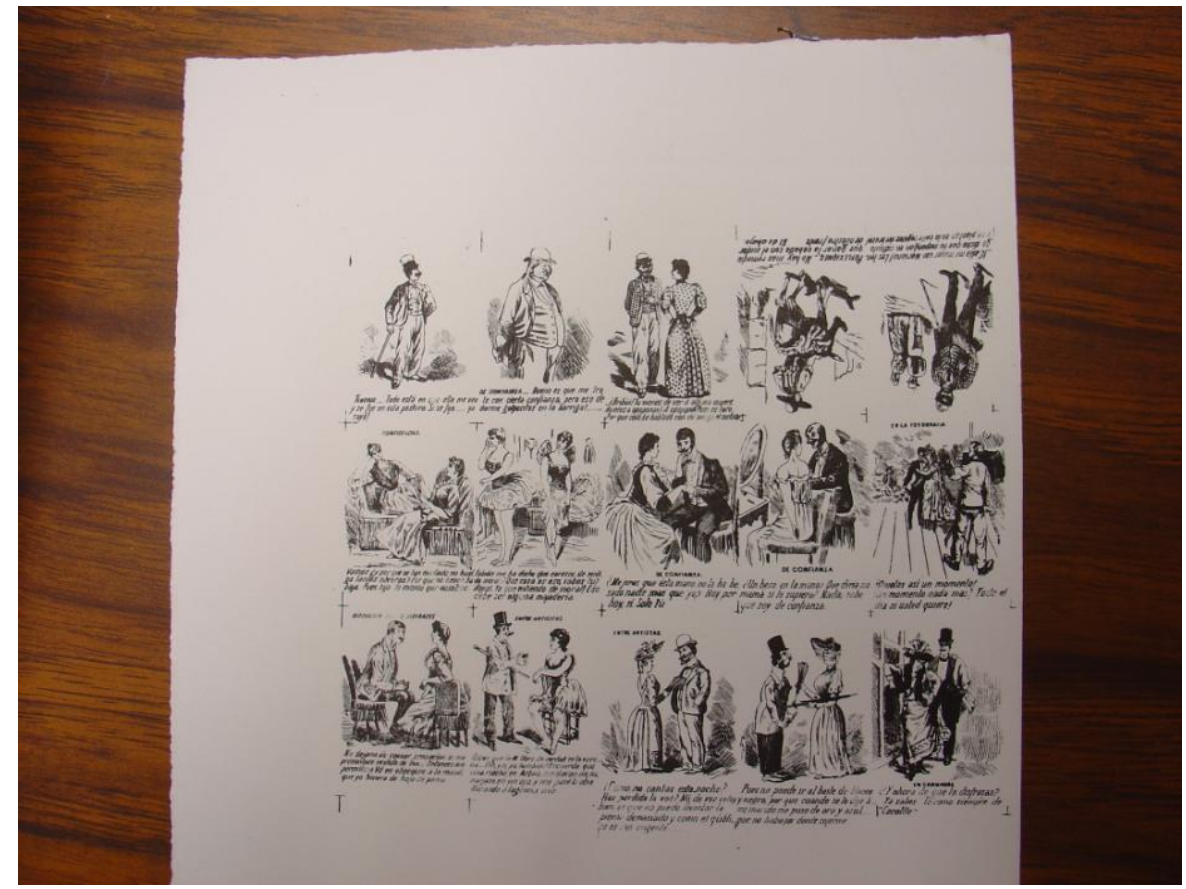

Figura 168 Historieta impresa a partir de una piedra litográfica de la ENAP Academia de San Carlos

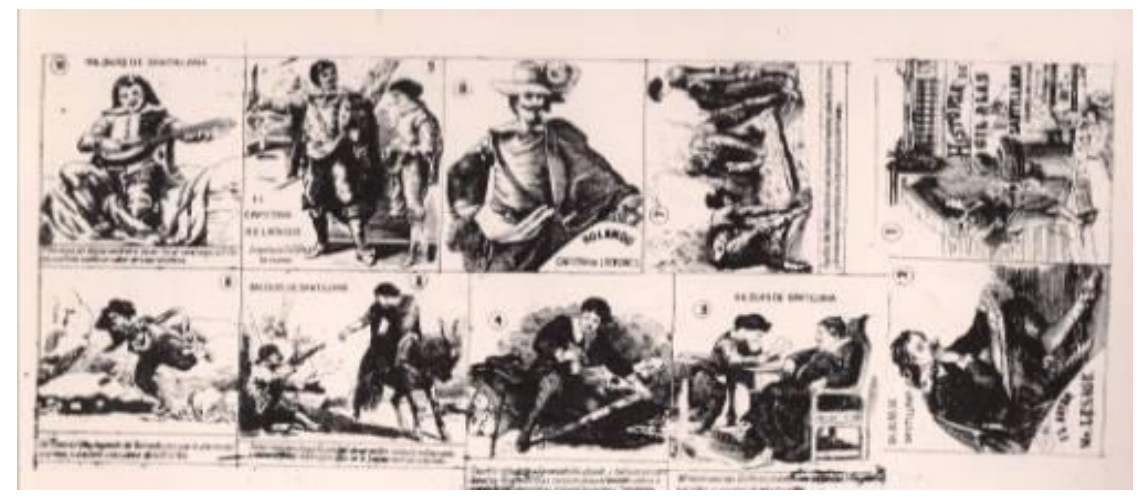

Figura 169 Gil Blas de Santillana. ENAP Colección de piedras litográficas Imp ${ }^{\circ}$ Laura Mayagoitia. 2002

Además de indicar el nombre de la fábrica que producía los cigarros en las etiquetas se mencionaba: el monto del capital social que manejaba, el nombre del director general que era el dueño, las marcas de cigarros que producían y estaban circulando, etc. 
Entonces otro recurso publicitario (Fig. 170) fue dibujar jeroglíficos a continuación presentamos uno que augura, de manera ingeniosa, el futuro de los productos de la fábrica cuando se acercaba el nuevo siglo.

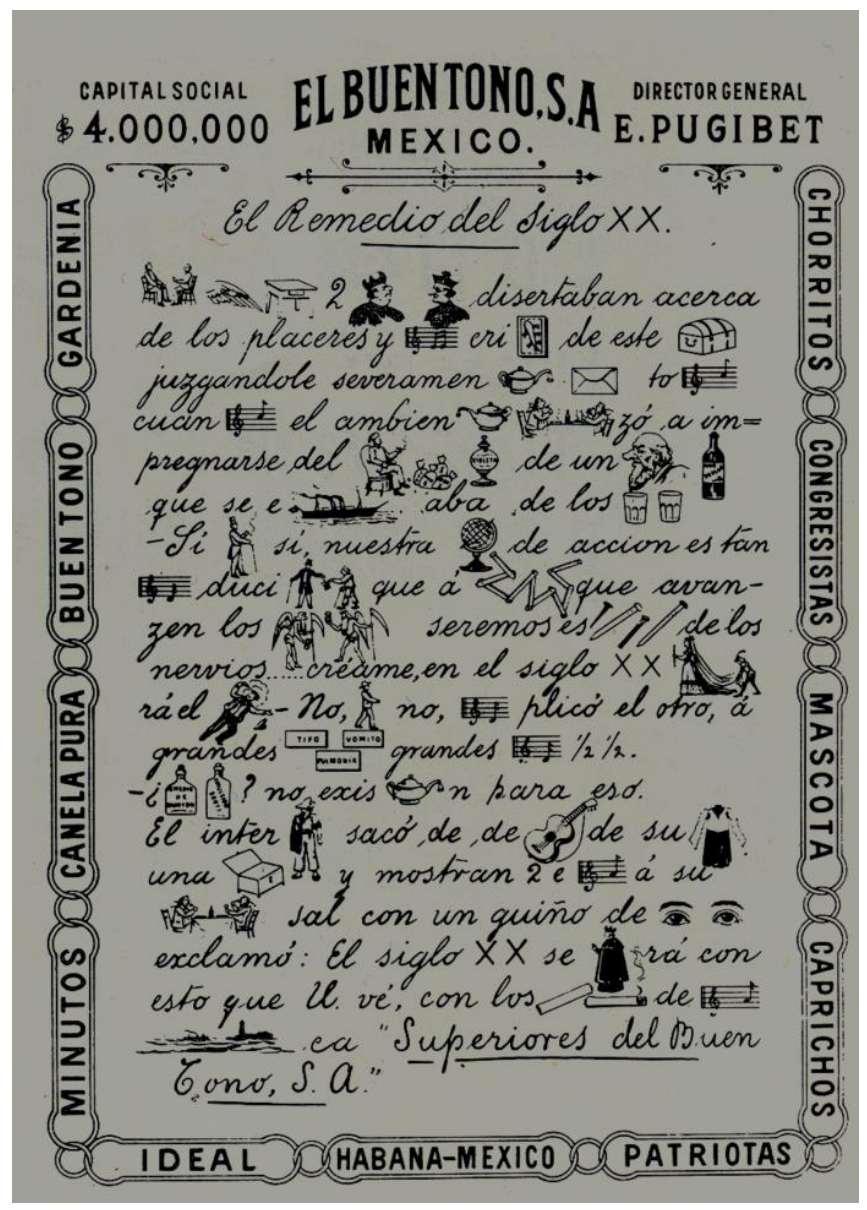

Figura 170 Litografía "El remedio del siglo XX" Jeroglífico de Urrutia

El artistas mexicano José Guadalupe Posada nació en Aguascalientes, México (1852-1913) no estuvo al margen del tema del tabaco, su primer maestro, fue Trinidad Pedroza, un excelente litógrafo y grabador en madera tenía buen gusto, pero según los críticos, era poco original. 


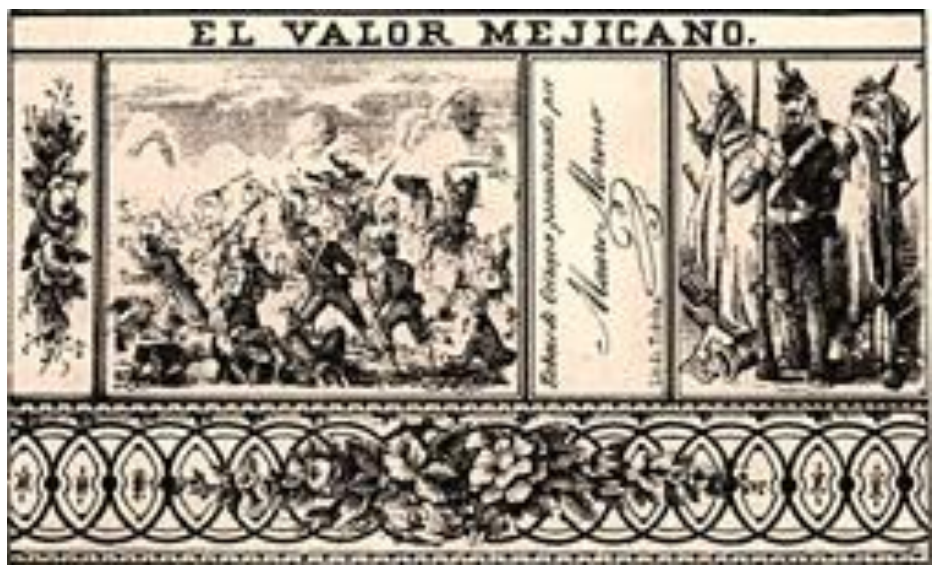

$171 \mathrm{~J}$. Guadalupe

Posada. ."El valor mejicano" Litografía para cajetilla de cigarros.

Litográfica de Trinidad Pedroza

Posada fue pintor y caricaturista, famoso por sus litografías de escenas de muerte, estampas populares y caricaturas sociales, inspiradas en el folclore. Ganó una plaza de maestro de litografía en la Escuela Preparatoria de León. Se había trasladado a esta ciudad del Estado de Guanajuato, en 1871en compañía de su maestro. Posada fue profesor durante cinco años, aunque compartió la actividad didáctica con lo que le gustaba en realidad: la litografía comercial -textos de anuncios y carteles- y la estampación de imágenes religiosas. Posada fue un magnífico grabador, sus obras litográficas, xilográficas y hueco grabado constituían más de 10000 piezas e incursionó también en el dibujo de imágenes para cajetillas de cigarros. Recibió el impacto de los ilustradores españoles, cuyas obras llegaban a México en los periódicos de España. Así lo observamos en las siguientes litografías. ${ }^{111}$

\footnotetext{
${ }^{111}$ Francisco Antúnez Madrigal. Primicias Litográficas del Grabador J.Guadalupe Posada. Aguascalientes, León 1872-76. México, Aguascalientes, Ediciones Rana-Instituto Cultural de Aguascalientes, 1952.
} 

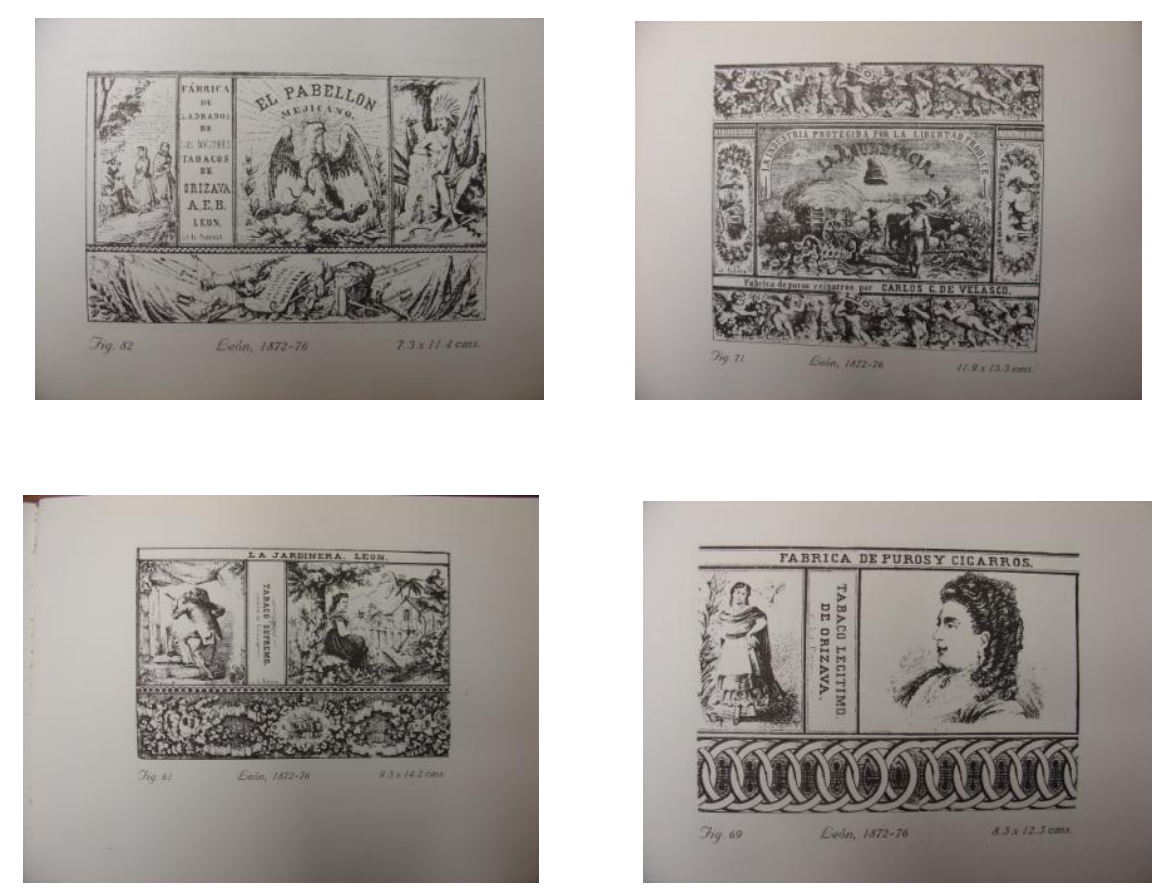

Figuras 172 José Guadalupe Posada. Litografías para cajetillas de cigarros.

Realizadas en León Guanajuato para la litográfica de Pedroza. 1872-76

Podemos observar que algunas imágenes de Posada corresponden a las del acervo Picaseño sin embargo en el siglo XIX no era costumbre que los litógrafos firmaran sus obras, de tal forma que el registro de autor pasaba a ser propiedad de la litográfica o de la fábrica de cigarros.

En los grabados que ejecutó en la ciudad de León, Guanajuato ilustrando tarjetas de visita, felicitaciones y envoltorios de cigarros (figs.172) comenzó a abandonar sus anteriores conceptos estéticos para producir un estilo más mexicano ${ }^{112}$ como podemos observar.

\footnotetext{
112 La Jornada Semanal, 3 de febrero del 2002núm. 361 en: http://www.jornada.unam.mx/2002/02/03/sem-gamboa.html
} 

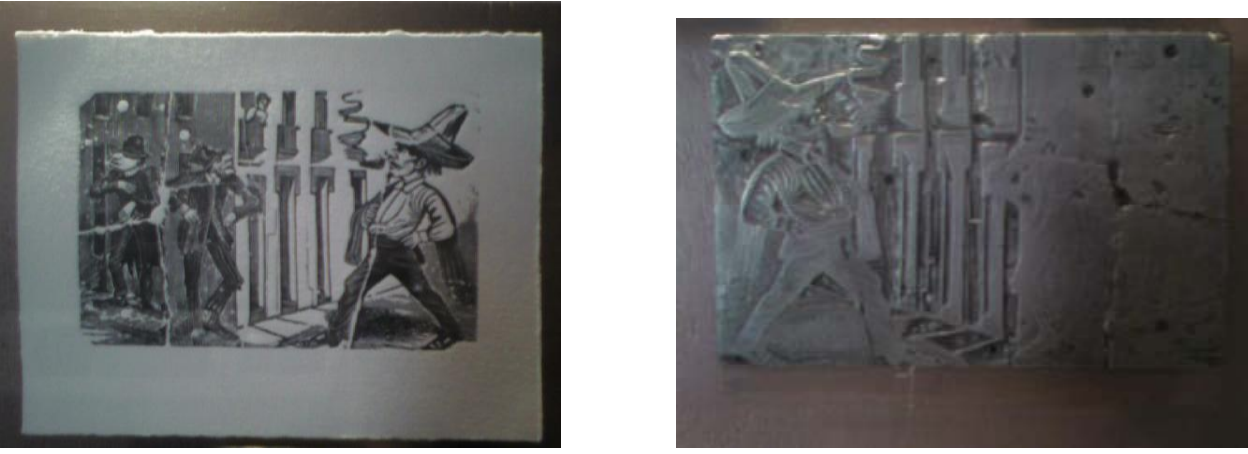

Figura 173 José Guadalupe Posada. Grabado y plancha. Museo Guadalupe Posada Aguascalientes. México $\mathrm{F}^{\circ}$ Mayagoitia 2009

Otro gran litógrafo mexicano fue Casimiro Castro $^{113}$ (1826-1889). Alumno de Pedro Gualdi en el arte del dibujo y la litografía. A partir de 1851 inició sus colaboraciones gráficas en La Ilustración Mexicana, editada por el reputado impresor Ignacio Cumplido. México y sus Alrededores fue la obra que lo proyectó a la fama hasta convertirse, sin duda, en el más famoso litógrafo mexicano, en algunas obras representaba hombres y mujeres fumando. México y sus Alrededores apareció publicado entre los años 1855 y 1856 por entregas para suscriptores o no, y después el previsor Decaen las reunió en un sólo volumen, razón por la cual existen ejemplares con diferente número de láminas. Los textos sirvieron como artículos descriptivos de las ilustraciones y fueron escritos por doce personas entre las que se encontraban José María Roa Bárcena, José T. Cuéllar, Francisco González Bocanegra. Las láminas más famosas son la vista de la Ciudad de México tomada desde un globo, así como las perspectivas aéreas de la Alameda y la Villa de Guadalupe. Entre las ilustraciones destaca "El fandango", con interesantes tipos populares. Casimiro Castro retrató prácticamente toda la ciudad de México: las elegantes fachadas, los barrios pobres, los monumentos

${ }^{113}$ Casimiro Castro y su taller. Álbum del Ferrocarril Mexicano. 1877 
y paseos, los canales y los lagos, los edificios barrocos novohispanos de fines del siglo XVIII, así como a diversos tipos de pobladores, desde el aguador, el arriero, el vendedor de frutas y el cargador, hasta el lépero más desarrapado. También supo captar los cambios a que daban lugar: la austeridad republicana: la propagación del traje negro, y la ropa hecha en serie, resultado de la revolución industrial. México en fin, se transformaba. En 1878 Castro ilustró el Álbum del Ferrocarril Mexicano y un par de años después asumió la dirección editorial del negocio de su suegro Ignacio Cumplido. Los últimos años de su vida los dedicó a viajar por Europa tomando apuntes al natural: vistas urbanas, monumentos, plazas y edificios.
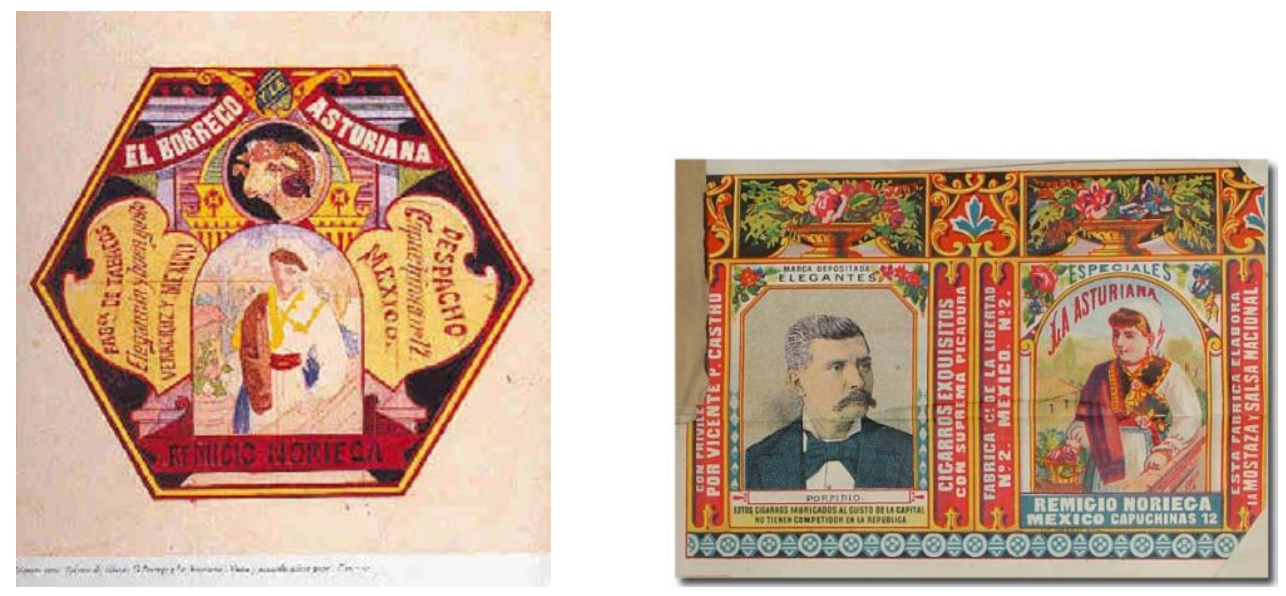

Figuras 174 y 175 Casimiro Castro. Acuarela para etiquetas de Cigarros El Borrego y Asturiana. Acervo Picaseño

Las dos imágenes que suceden fueron impresas a partir de las piedras de la Academia de San Carlos, la marca "El Peso Fuerte" (fig. 176 izquierda y 177):

Encontramos una piedra litográfica que seguramente sirvió para imprimir algunas etiquetas que encontramos en el acervo Picaseño, aun cuando las leyendas y las imágenes femeninas fueran diferentes. 

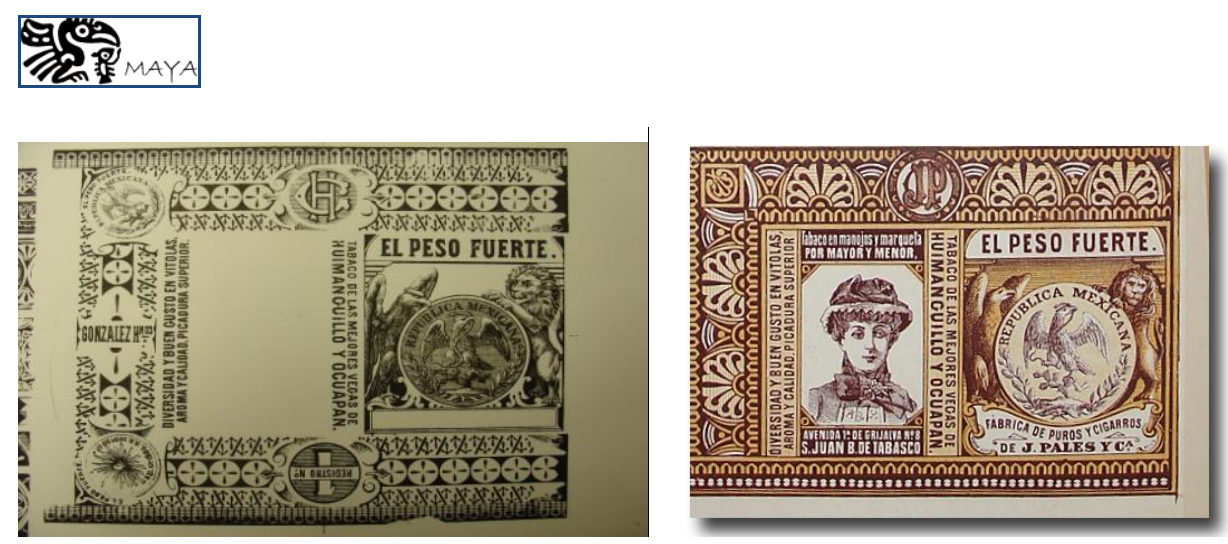

Figura 176 Etiqueta de cigarros "El peso fuerte" Tabacos de las mejores vegas de Huimanguillo y Ocuapan González y Hnos. Diversidad y buen gusto en vitolas aroma y calidad picadura superior.

Imprimió L. Mayagoitia. Academia de San Carlos, 2003. (Izquierda).

Figura 177 Derecha: Litografía "El Peso Fuerte" Fabrica de puros y cigarros de J. Pales y C. Tabaco en manojos y marqueta por mayor y menor. Av. 1 de Grijalva No 1 S. Juan B. Tabasco

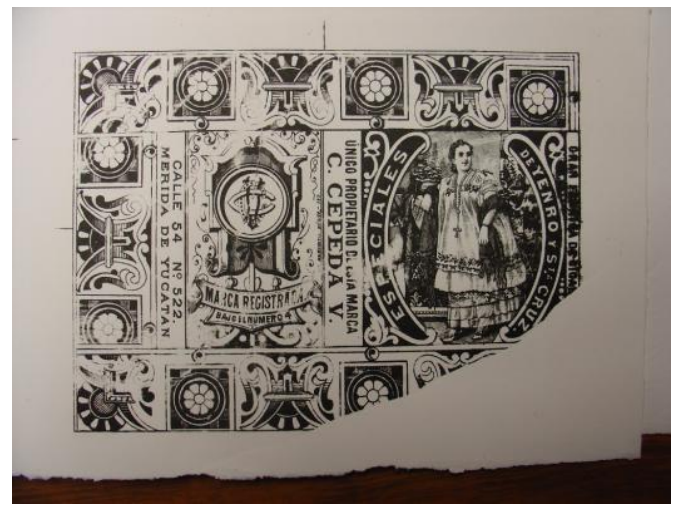

Figura178 Etiqueta de cigarros "Especiales de Yenroy Santa Cruz" C. Cepeda V. Único propietario de la marca. Calle 54 №522 Mérida Yucatán. Marca registrada bajo el número 4. Imprimió L. Mayagoitia. Academia de San Carlos.

Etiquetas con muchos o pocos detalles, algunas hacían hincapié en personajes célebres, imágenes femeninas, edificios, animales, flores etc. En Morelia, Gabino Oseguera publicitaba sus cigarros que tenían el Registro No 3 y su dirección era Cerrada de San Agustín No 12 a continuación presentamos una impresión tomada de una piedra litográfica de la colección de la Academia de San Carlos de México con separación de color. 

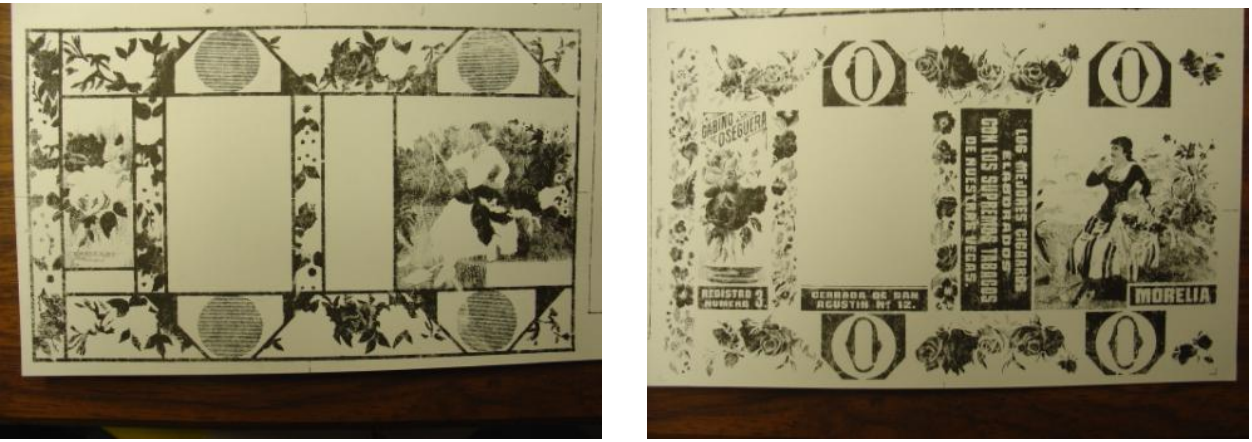

Figura 179 Gabino Oseguera. Registro No 3 Cerrada de San Agustín No 12 Los mejores cigarros elaborados con los supremos tabacos de nuestras vegas. Morelia. Imprimió L. Mayagoitia. Academia de San Carlos, 2003

(separación de color).

Después de haber presentado las formas en que se publicitaba la acción de fumar en diversas fuentes escritas y visuales, reconocemos que los artistas extranjeros y posteriormente los mexicanos a través de la técnica litográfica aportaron ideas, experiencias y describieron lo que dimos por llamar el arte de fumar, que propició el consumo del tabaco, no solo en México sino en todo el mundo.

La litografía comercial también fue mejorando de calidad, al principio las imágenes eran impresas en una sola tinta y poco a poco se fueron utilizando otros colores y tintas, y papel el "Revolución" que era procesado en fábricas mexicanas fue sustituido por otros más finos para lograr imprimir etiquetas más elegantes que coincidieran con la calidad de los más finos tabacos, puros y cigarros. En el siguiente capítulo abordaremos el tema del Porfiriato y la evolución que en este largo periodo presidencial tuvieron el tabaco, el papel y especialmente la litografía. 


\subsection{EL REGISTRO DE PROPIEDAD ARTÍSTICA}

En México, el registro de propiedad literaria, había sido competencia del Ministerio de Relaciones Exteriores e Interiores, el Decreto relacionado se publicó el 3 de diciembre de $1846^{114}$. Se consideraba que era un deber del Gobierno "asegurar la propiedad intelectual de los trabajos que son obra del talento y la instrucción por su favorable influencia en la literatura y en las ciencias". La legislación estipulaba que el autor de cualquier obra, tenía derecho de propiedad literaria, es decir, la facultad de publicarla e impedir que otro lo hiciera, derecho vigente durante la vida del autor, al morir el derecho se adjudicaría a su viuda, de ella a sus hijos y demás herederos, durante 30 años.

En la legislación fueron incluidos pintores, músicos, grabadores, escultores y, en general, los autores de obras originales, sin distinción de nacionalidad, siendo suficiente el hecho de que la obra o su publicación se hubiera realizado en la República Mexicana. En España el Real Decreto del 20 de noviembre de 1850 también obligó el uso y propiedad de marcas de distintas fábricas obligando a empresarios a identificar sus productos, principalmente los envasados en cuyas envolturas deberían colocar el nombre del fabricante, licencias fiscales, lugar y ubicación de la empresa. ${ }^{115}$. Hasta 1865 el Decreto Real del 30 de noviembre obligó a los fabricantes que solicitaran marca para distinguir los productos de su industria, y

\footnotetext{
${ }^{114}$ Elizabeth Fuentes Rojas. Catálogo de los Archivos Documentales de la Academia de San Carlos (1900-1929) México, UNAM-ENAP 2000 p. 19

${ }^{115}$ Lidón Op. Cit. p 49
} 
presentar dos ejemplares del diseño y de la nota explicativa del mismo, uno para el Ministerio de Fomento y otro en el Conservatorio de Artes $^{116}$.

La legislación autoral en México fue modificada en1883 ${ }^{117}$, e incluida en el Código Civil del Distrito Federal (14 de diciembre de 1883). La Ley expedida por el Ministerio de Justicia e Instrucción Pública, dividía en tres capítulos la propiedad del autor: En el primero, de propiedad literaria, quedaban comprendidas: las obras originales, lecciones orales y escritas, alegatos y discursos pronunciados en asambleas políticas; las cartas particulares; publicaciones de academias e institutos científicos y literarios; obras colectivas (enciclopedias, diccionarios y periódicos); artículos científicos, literarios o artísticos en periódicos políticos y la primera publicación de códices.

${ }^{116}$ Ibid. p 50

${ }^{117}$ Fuentes Rojas Elizabeth. Op. Cit. p 20 


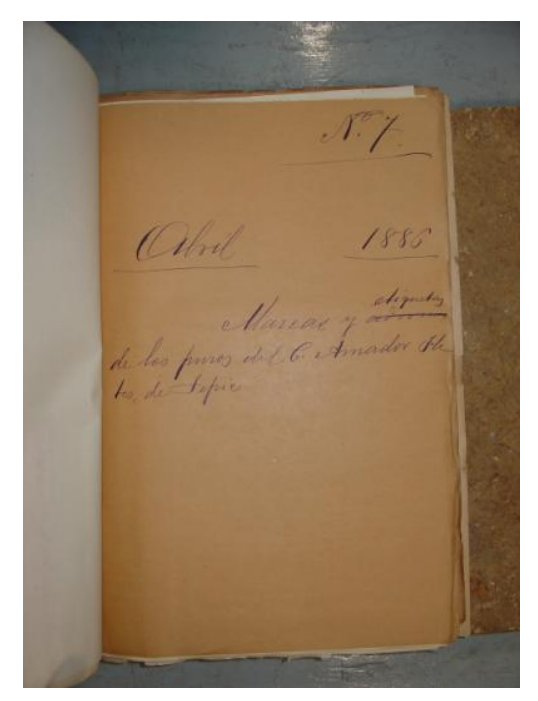

Figura 180 Expediente del Registro Autora Abril de 1866. Marcas y etiquetas de los Puros del C. Amador Fletes de Tepic Acervo Lino Picaseño. UNAM

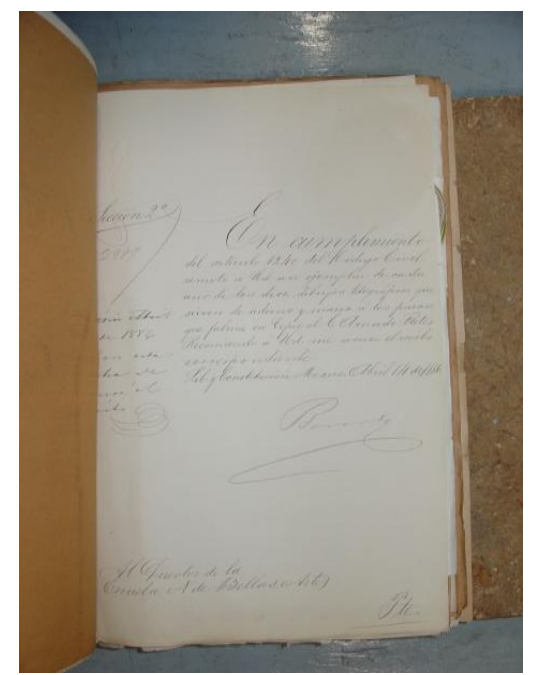

Figura 181 Expediente del Registro de propiedad artística de etiquetas de los puros de Amador Fletes, Tepic.

Acervo Lino Picaseño. UNAM

En el capítulo segundo estaban incluidas: la propiedad de obras dramáticas originales y su representación, y finalmente en el tercero, dedicado a la propiedad artística, se reservaba para la propiedad de los autores de cartas geográficas, litográficas, científicas, arquitectónicas, planos, dibujos y diseños (arquitectos, pintores, grabadores, litógrafos y fotógrafos; escultores por obra concluida, o por modelos y moldes; músicos y calígrafos).

El registro autoral para adquirir la propiedad artística o literaria comenzó a funcionar en 1871, para realizar el trámite, el autor o su representante debía recurrir al Ministerio de Instrucción Pública y entregar dos ejemplares de su obra, reservando así sus derechos. El primer ejemplar se depositaba en el Archivo General de la Nación, y el segundo, en caso de ser un libro, se remitía a la Biblioteca 
Nacional; las obras de música se destinaban al Conservatorio Nacional y los grabados y litografías a la Escuela de Bellas Artes.

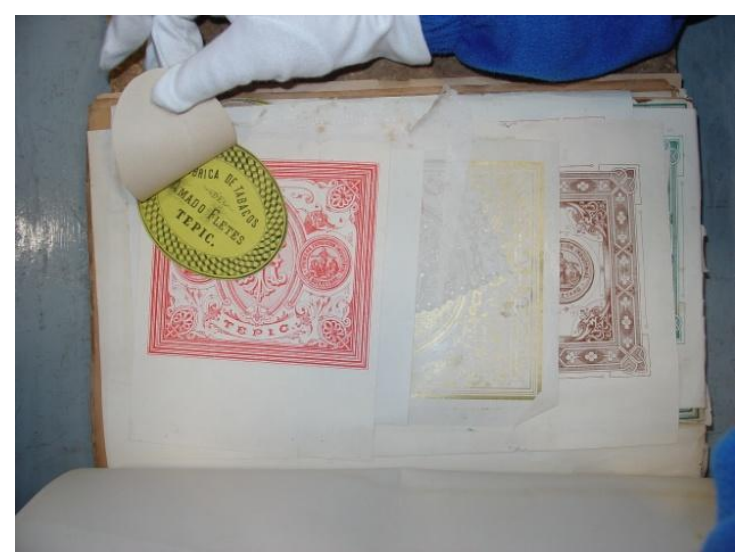

Figura182 Etiquetas de puros de la marca Amador Fletes. Acervo Lino Picaseño. Fotografía L. Mayagoitia

Entre 1904 y 1917 el registro dependió de la Secretaría de Instrucción Pública y Bellas Artes; en 1917 quedó bajo el

Departamento Universitario y de Bellas Artes, y a partir de 1921 de la Secretaría de Educación Pública ${ }^{118}$.

Las obras literarias y artísticas, entre las cuales se encontraban las etiquetas de cigarros y puros, estaban frente a la censura de la iglesia, las familias "de buenas costumbres" el ministerio de educación etc., por esta razón el procurador general de justicia Sr. Castañeda Nájera mandó a los periódicos, en 1889 una circular en la que recomendaba las inspecciones de policía para recoger las envolturas que contuvieran "escenas inmorales":

"Generalizándose más y más cada día el uso del tabaco, muy especialmente entre los jóvenes - pudiera decirse entre los niños- van a dar a sus manos esos impresos y tiene para ellos una enseñanza que tiene que dar sus frutos, en efecto tanto las figuras como las especies de 
doble sentido que se leen en muchas cajetillas, no pueden menos que llevar en sí el germen de la perversión, y esto es lo que se pretende contener" ${ }^{119}$

Algunos periódicos haciendo eco al procurador de justicia aconsejaban a los fabricantes que en vez de imprimir esos episodios "de manera de ser de las "cocotes" (prostitutas) deberían reproducir episodios de la historia nacional y ayudarían positivamente en la ilustración de las masas encontrando más apoyo en las personas que deseaban mayor progreso moral y material de la república. Otros sugirieron incluir problemas de aritmética, cuentos morales, fechas notables, que sirvieran de entretenimiento lícito y lección para el pueblo Sin embargo la orden del Procurador de Justicia no se cumplió cabalmente. ${ }^{120}$

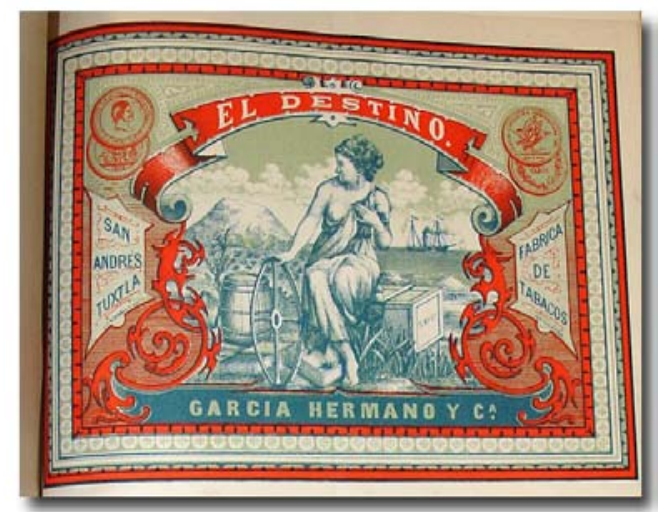

Figura 183 “El Destino” García Hermano y Cía. San Andrés Tuxtla. Fábrica de Tabacos.

Aun cuando los temas políticos eran fundamentales, muchos grabadores incursionaban de manera poderosa en el ámbito de la publicidad comercial dibujando y grabando etiquetas que poco a poco fueron presentadas para ser registradas como propiedad artística a favor de los dueños de las empresas tabacaleras: Víctor

${ }^{119}$ Eduardo Pesqueira Olea. Historia y cultura del tabaco en México. México, TabamexSecretaria de Agricultura y Ganadería, 1985.

${ }^{120}$ Ibid. 
Fos, Henry Clay, Ernesto Pugibet, Olavarrieta, Jesús Hernández, Juan Beillas, Julio Pugibet, B. Prida y Cía. Tovar Ramírez, Jacinto Carmona y Cía., Gregorio Palacios, José M. Merino, Pablo Fajardo, J. Unda, Julio Segarra, Juan Hegaral Sucs., Roca y Carreta, Daniel Blumenkron, Miguel M. Gradida, Gregorio Palacio, Bollinger y Astorquiza, Fernández y Bermejillo, Ruiz Oceguera y Cía., Ibarguen y Abasolo, Donato González, Miguel Guerrero, Campos y Cía., J.M Carballedo, Aguilar y Cía., Vicente Fernández P., Murguía Hnos., Valente A del Castillo, José Fernández y Cía., Cesáreo Uribe, Rafael Torres, Julio E.Unink, Benito Hortube y Cía., José Benett, Bollinger y Victoria, Ignacio Botello, García Hno y Cía., Ignacio Alamo y Cía., Jacinto Carmona y Cía., Delgado y Naverán Cia, Astorquiza y Toriello, Juan Mucio Pérez, Ramiro Tarves y Cía., Remigio Noriega, Eusebio Castellanos, Rafael Torres e Hijos, Ignacio Álvarez, Anastasio Martínez, Enrique Escudero y Cía., Mercado Hermano, Amador Fletes, García y Arroyo, Pedro A. Piza y Dolores Martínez de Piza, González Hnos. y Cía., Ángel Almada y Cía., M. Penichet y Sucs., etc. Estos datos los hemos compendiado en el sistema automatizado Maya que presentaremos en el capítulo 5 de esta tesis. 


\section{CAPITULO 4. EL PORFIRIATO Y LA PRODUCCIÓN LITOGRÁFICA COMERCIAL DE ETIQUETAS DE TABACO.}

Es importante señalar que las obras de Humboldt y Stephens atrajeron la atención de una nueva generación de viajeros, científicos historiadores y arqueólogos. A ellos se debe la primera edición de obras maestras mesoamericanas Antigüedades mexicanas de Kingsborough (1831-1838) Colección de Antigüedades Mexicanas que existen en el Museo Nacional de Jean Federic Waldeck (17661875), etc. El interés por el mundo prehispánico como parte de una visión nacionalista se expresó en monumentos, pinturas y en algunas litografías y no escaparon de esta corriente las etiquetas de cigarros de la colección Picaseño que obtuvieron su registro de autor.
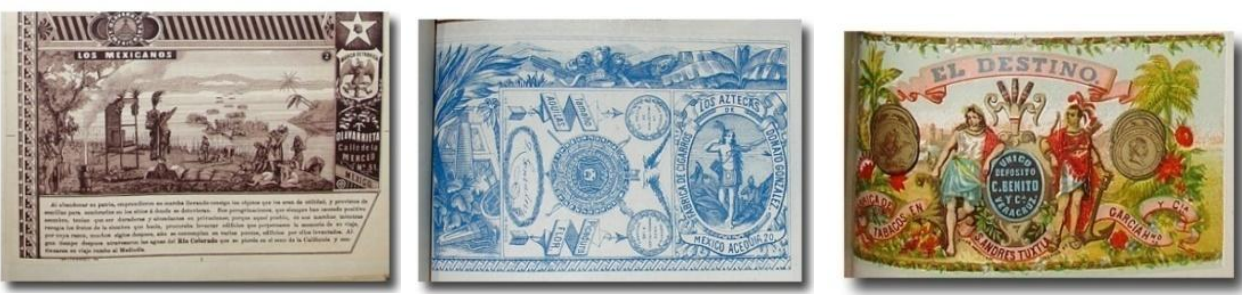

Figuras 184, 185 y 186 Etiquetas de cigarros de las marcas "Los Mexicanos", "Los Aztecas" y "El Destino" de las fábricas de Olavarrieta. Donato González y García Hno. y Cía.

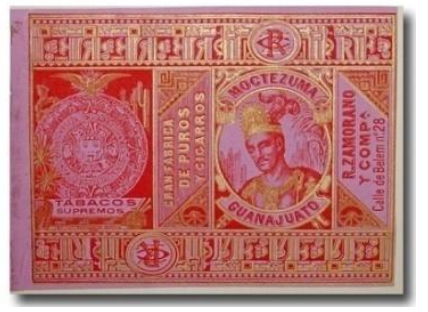

Figura 187 Tabacos supremos- Gran fábrica de puros y cigarros."Moctezuma". Guanajuato. R. Zamorano y Comp. Calle de Belem 28 


\subsection{ALGUNOS DÍAS DE DÍAZ: EL PORFIRIATO.}

Muchos estudios sobre arte del Siglo XIX en México, hacen constar que la pintura, la escultura y la litografía estuvieron influenciadas por tres temas del ideario político: la independencia, la consolidación del Estado y la exaltación del caudillo bajo cuya gestión se lograron esos fines: Porfirio Díaz. Durante el porfiriato se hacen obras monumentales para celebrar la Independencia de México, exaltándose la figura de Miguel Hidalgo y Costilla quien dio origen al movimiento insurgente y los artistas y políticos ratificaron esta idea durante el siglo XIX. Hidalgo, por ejemplo es hermanado con las figuras de Jorge Washington y Simón Bolivar, la etiqueta que mostramos a continuación, pertenece al registro de autor de Donato González quien tenía su fábrica de puros en Acequia 20 en la Ciudad de México.

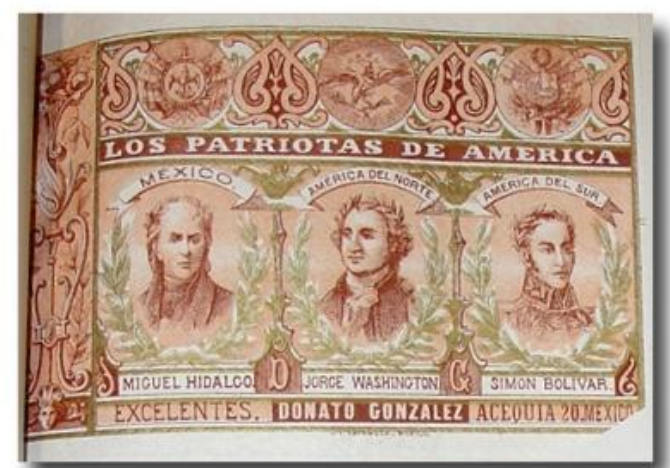

Figura 188 "Los patriotas de América" México, América del Norte, América del Sur. Miguel Hidalgo, Jorge Washington Simón Bolívar. Excelentes. Donato González, Acequia 20 México

Tenemos dos etiquetas más representando a Miguel Hidalgo: la primera de la fábrica de Fernández y Bermejillo "El caudillo Mexicano" en la que observamos de lado izquierdo a dos mujeres, la 
figura más grande aparece como una alegoría, porta un gorro frigio y una rama de tabaco en la mano izquierda. A su lado un yunque y una rueda símbolos de la modernidad. La mujer en el espacio frontal, un poco más pequeña, aparece vestida con el atuendo indígena mexicano (fig. 189).

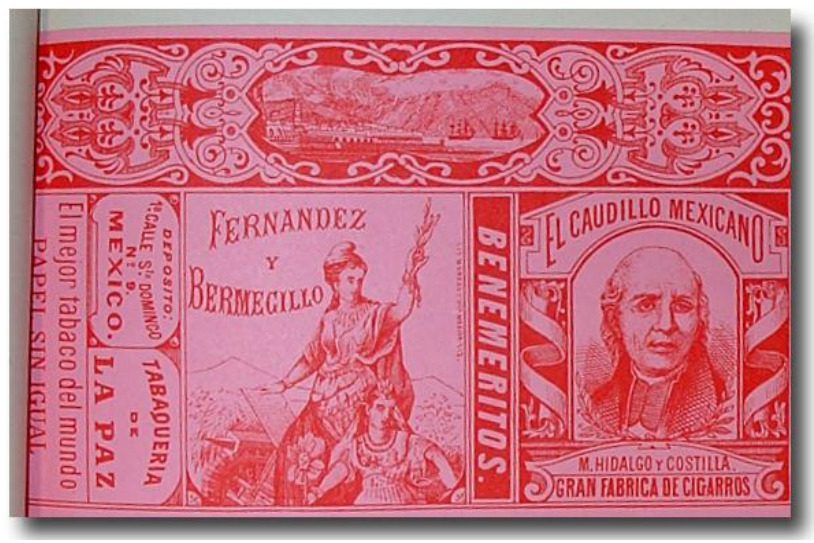

Figura 189 Fernández y Bermejillo. "El Caudillo Mexicano" M. Hidalgo y Costilla. Gran fábrica de cigarros. Depósito 1aㅡ Calle de Sto. Domingo No. 9 Tabaquería de la Paz. El mejor tabaco del mundo. Papel sin igual.

La segunda etiqueta de la fábrica de Villa y Hermano (fig.190) presenta la imagen de Hidalgo y en el lado izquierdo la de Juan Nepomuceno ${ }^{121}$ quien combatió siendo aún niño al lado de su padre José María Morelos. Años más tarde formó parte de la comisión encargada de entablar relaciones con Estados Unidos y conseguir apoyo económico para la guerra de independencia. Estudió y permaneció en Nueva Orleans hasta 1821. Regresó a México durante la firma del Plan de Iguala. Al ser coronado Agustín de Iturbide se marchó de nuevo a Estados Unidos. Cuando cayó el imperio de Iturbide, Almonte regresó a México para ser enviado casi de inmediato a Londres como encargado de negocios. Participó en la comisión para fijar los límites entre México y Estados Unidos (1834) y

\footnotetext{
${ }^{121}$ Alberto Leduc y Luis Lara y Prado Diccionario de Geografía, Historia y Biografías Mexicanas. México, Imprenta de la Viuda de C. Bouret. México 1910 p. 34
} 
aprehendido cuando participaba en la Guerra de Texas. Al ser liberado, el presidente Anastasio Bustamante lo nombró Secretario de Guerra y Marina y luego representante de su gobierno ante Estados Unidos (1842). Fue partidario de la guerra contra Estados Unidos y ocupó el puesto de Secretario de Guerra en 1846.

En 1857 se negó a firmar la ley de expropiación de los bienes del clero y se adhirió al Partido Conservador. Firmó el Tratado MontAlmonte en Europa comprometiéndose a pagar a España y a los españoles los adeudos pendientes a cambio de ayuda económica contra los liberales. Al triunfo de éstos radica en Europa y encabeza el movimiento para ofrecer el trono de México a Maximiliano de Habsburgo quien más tarde le daría cargos importantes: lugarteniente del emperador y luego mariscal del imperio, en 1866 fue comisionado para pedir a Napoleón III que no retirara a las tropas francesas de México, objetivo en el que fracasó, entonces decidió permanecer en París, donde falleció el 21 de marzo de 1869.

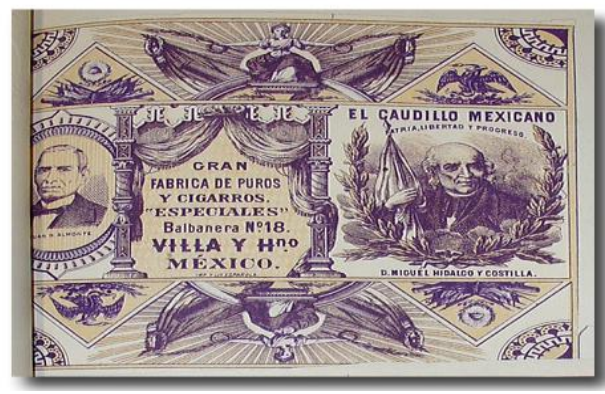

Figura 190 "El Caudillo Mexicano" Patria libertad y progreso. Gran Fábrica de puros y cigarros especiales Balbanera No 18.Villa y Hno. México (imágenes de Juan Almonte y Miguel Hidalgo y Costilla)

El porfiriato fue, sin lugar a dudas, un periodo gubernamental de discrepancias pero también de progreso. Porfirio Díaz oriundo de Oaxaca, había sido a los 11 años aprendiz de carpintero y a los 14 ingresó al seminario Conciliar de Oaxaca en calidad de oyente. 
Estudió latinidad y filosofía, conoció a Benito Juárez quien lo inspiró a abandonar el Seminario, entonces se inscribió al Instituto de Ciencias y Artes de Oaxaca, en donde estudió la carrera de abogado y obtuvo el cargo de bibliotecario. Iniciado en los ritos de la masonería, en la que era venerable Benito Juárez, Díaz mostró siempre hostilidad en contra del gobierno del General Santa Anna. Algunas litografías del acervo Lino Picaseño son referencias iconográficas de este personaje y hacen alusión a sus batallas, a lo largo de este capítulo las podremos ir observando.

Dentro de su desempeño militar, Díaz fue considerado siempre un buen estratega, había estudiado un curso de estrategia y táctica militar en 1852, su primera batalla contra el gobierno de Antonio López de Santa Anna fue incorporándose a la guerrilla de José María Herrera en Teotongo ${ }^{122}$.

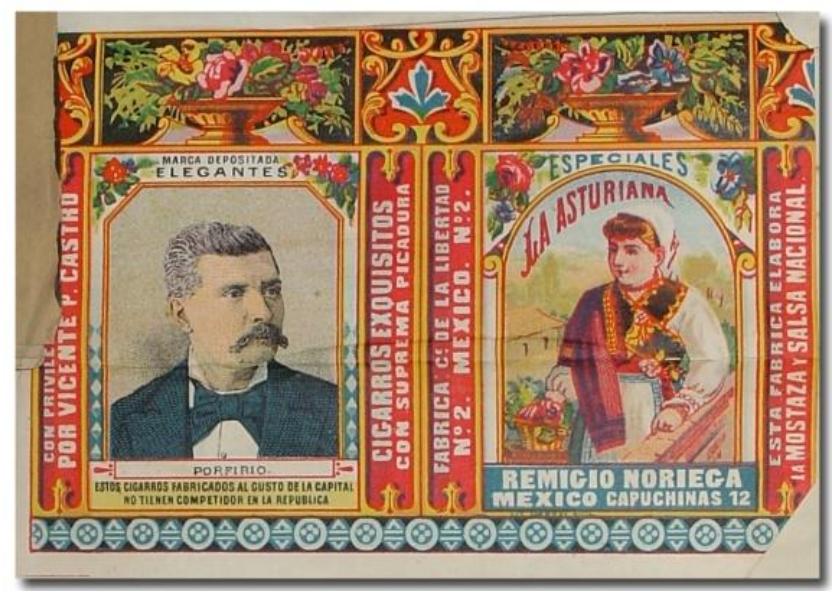

Figura 191 "Porfirio" Propiedad Artística Remigio Noriega. Firma Baranda. Registro de la Academia de San Carlos 11061. Marca depositada "La Asturiana".

Fábrica de cigarros y puros de picadura de hebra. Capuchinas 12 México. Fábrica Calle de la Libertad No. 2 México

En 1855 Santa Anna se exilió del país y Díaz fue nombrado Sub prefecto del distrito de Ixtlán, en sólo un año pudo organizar la

\footnotetext{
${ }^{122}$ Ignacio Escudero M. Historia Militar del General Porfirio Día. México, Cosmos 1975 p. 4
} 
Guardia Nacional y Capitán de Infantería. Participó en diversas batallas, como la toma de la plaza de Jalapa, en Oaxaca. En un enfrentamiento contra los conservadores en Tehuantepec ${ }^{123}$, condujo armamento desde Minatitlán hasta la Ventosa, esta acción que le sirvió para ser ascendido a coronel de infantería. En 1860 sostuvo dos acciones militares: una en el Fortín de la Soledad, otra en el Marquesado y la toma de Oaxaca. Siendo diputado federal por el Estado de Oaxaca en 1861, Díaz pidió permiso para ir a combatir al General Márquez, quien amenazaba la Ciudad de México ${ }^{124}$. Bajo las órdenes de González Ortega derrotó a Leonardo Márquez en Jalaltlaco con lo que Juárez otorgó el grado de General de Brigada a Díaz quien volvió a derrotar a Márquez en Pachuca. Posteriormente en 1862, Porfirio Díaz participó en la batalla de Puebla contra los franceses en el punto llamado La Ladrillera ${ }^{125}$ y en Puebla defendió los fuertes de Santa Inés y San Marcos (1863) luchó contra el Coronel Forey y sus 36000 soldados $^{126}$. En Nanahuatipán sorprendió a los franceses, pero se retiró con pérdidas notables por falta de apoyo. Después de un mes de lucha y de haber entregado la plaza al coronel Bazaine, Díaz fue trasladado a Puebla como prisionero de guerra, pero se fugó de prisión.

La imagen litográfica recoge los combates librados contra los intervensionistas franceses y elevan a nivel de héroe nacional a Ignacio Zaragoza y al mismo Porfirio Díaz triunfador de la batalla del 2 de abril de 1867 en Puebla ${ }^{127}$ como lo observamos en la etiquetas de la fábrica de Ruiz Oseguera.

\footnotetext{
${ }^{123}$ Ibidem p. 19

${ }^{124}$ Ibid. Pp 31-33

${ }^{125}$ Ibid. p.51

${ }^{126}$ Ibid. p. 72

127 Ibid. p 115
} 


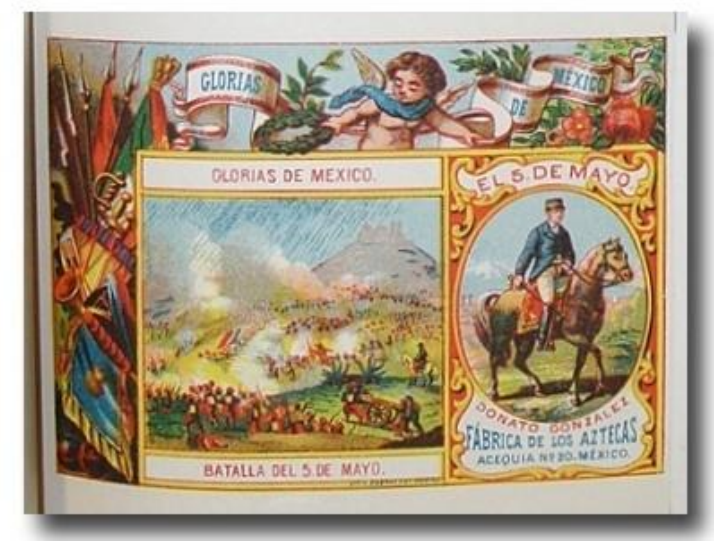

Figura 192 Fábrica Los Aztecas y registro de propiedad artística de Donato González, fecha 25 julio de 1884. Marca Glorias de México Batalla "El 5 de mayo"

Firma Baranda. Registro de la Guía de la Academia de San Carlos 11010. Litográfica de Debray.
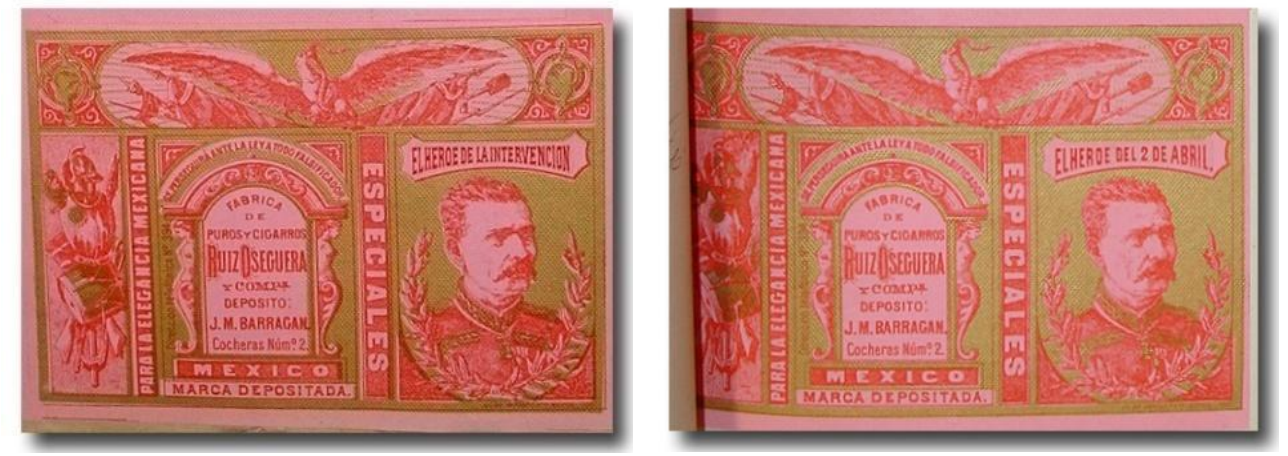

Figs. 193 y 194 Etiquetas de la fábrica de puros y cigarros de Ruiz Oseguera. "El héroe de la intervención y "El héroe del 2 de abril"

La Secretaría de Guerra devolvió a Díaz el mando de la Línea de Oriente y se enfrentó a los franceses en Tlaxiaco, Pinotepa, Jamitepec, Putla, Huahuapan y Nochistlán. Díaz siempre consideró la Batalla de Miahuatlán del 3 de octubre de 1866, contra los franceses la de mejor estrategia y la más fructífera durante la guerra de Intervención, pues le había abierto las puertas de Oaxaca, Puebla y México ${ }^{128}$. En La Carbonera interceptó y derrotó a 1300 hombres que iban en auxilio a las tropas imperiales sitiadas en la Ciudad de Oaxaca.

${ }^{128}$ Escudero Ignacio. Op. Cit. pp 97-99 
Don Porfirio, rechazó cooperar con el gobierno Imperial de Maximiliano y después de varias semanas de sitio sobre Puebla, y ante el avance de Márquez para auxiliar a los imperialistas, Díaz se apoderó de la plaza por medio de un asalto. Durante la Batalla de San Lorenzo enfrentó a las tropas imperialistas de Márquez, Khevenhuller y Kodolich. Después de sesenta y tres días de sitio el General Mariano Escobedo tomó Querétaro. Maximiliano fue aprehendido y junto con Miramón y Tomás Mejía, fusilados en 1867 en el Cerro de las Campanas. La ciudad de México se rindió pacíficamente, entonces Benito Juárez entró a la ciudad en donde fue recibido por Porfirio Díaz.

En Guadalajara cuando Juárez y sus ministros iban a ser fusilados por la guardia del palacio, Guillermo Prieto se interpuso entre los guardias y el Presidente diciendo la célebre frase:"Los valientes no asesinan". Poco después los guardias nacionales, los estudiantes y el pueblo liberaron a los presos y el magistrado pudo salir de Guadalajara con rumbo a la costa (fig.195).

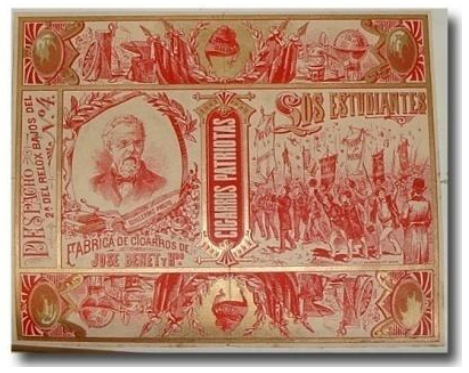

Figura 195 Cigarros “Los patriotas”. Fábrica de cigarros de José Benet y Hno.

A partir de 1867, el general Díaz continuó encabezando el ejército de Oriente con cuartel en Tehuacán. Después de renunciar a la Segunda División del Ejército regresó a la ciudad de Oaxaca, en donde fue recibido como héroe nacional y se trasladó la Hacienda de la Noria. 
En 1871 por decreto solemne, Juárez fue declarado presidente la República y el candidato de oposición fue Porfirio Díaz. En Oaxaca Díaz desconoció al gobierno de Juárez y se levantó en armas con el Plan de la Noria. Auxiliado por Teodoro Dehesa, Porfirio (Fig. 196) salió de México con el pseudónimo de Antonio Mauri, embarcándose en el vapor "Córcia" estuvo algunos días en Nueva York y regresó a México proclamándose en guerra en Camargo.

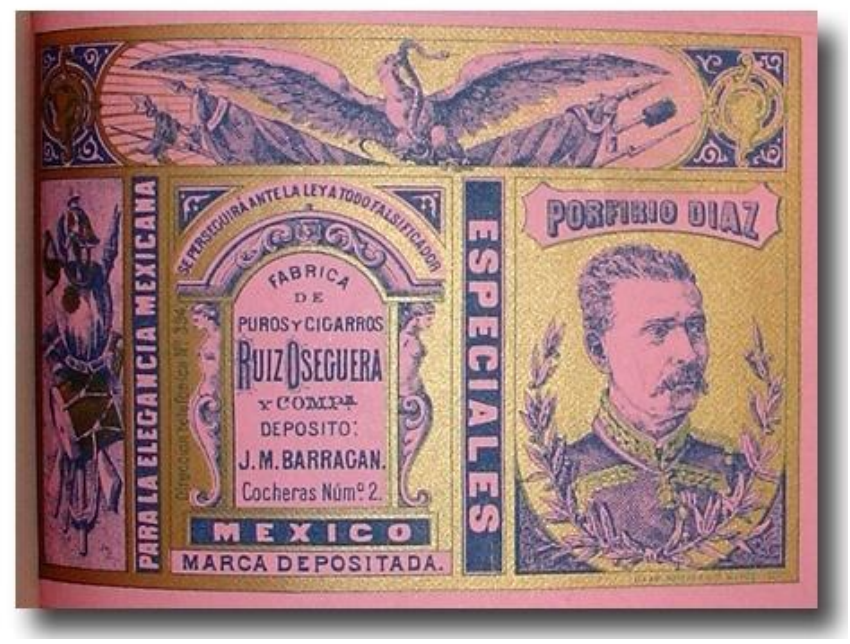

Figura 196. "Porfirio Díaz" Para la elegancia mexicana. Se perseguirá ante la ley a todo falsificadorFábrica de puros y cigarros Ruiz Oceguera y Comp. Depósito J.M: Barragán Cocheras Núm. 2 México. Marca Especiales

Ante la muerte de Benito Juárez, asumió el poder Sebastián Lerdo de Tejada quien era presidente de la Suprema Corte de Justicia, mientras tanto en Durango el gobernador avisó que Don Porfirio estaba dispuesto a entregar sus armas al gobierno. Díaz va a México y se entrevista con el presidente Lerdo, quien le aseguró amplia libertad y en 1874 fue electo diputado al Congreso de la Unión. 
Al promulgarse el Plan de Tuxtepec, Díaz y algunos de sus amigos cercanos (Ireneo Paz, Ignacio Ramírez, Protasio Tagle, José Justo Benítez, Jerónimo Treviño y Manuel González) se levantaron en armas contra el gobierno de Lerdo. Díaz se adhirió al plan de Tuxtepec, e invadió Palo Blanco, Tamaulipas, al grito de "Sufragio efectivo, no reelección" curiosamente al paso de los años el estaría en la presidencia 30 años reeligiéndose durante 6 periodos. La prensa denominó a Díaz el "llorón de Icamole" por su derrota en la batalla de Icamole en Coahuila en 1876.

Don Porfirio viajó de México hacia Nueva York en donde se embarcó en el vapor "City of Havana" pero al ser descubierto por las fuerzas lerdistas al llegar a Tampico, se tiró al mar para escapar, después volvió a embarcarse y llegó a Veracruz, con el asistencia del capitán del barco. Apoyado por el General Manuel González, el 16 de noviembre de 1876 Díaz derrotó a las fuerzas lerdistas en la batalla de Tecoac (Fig.197) y entró triunfal a la ciudad de México. En tanto, Lerdo huyó a Estados Unidos y Díaz fue nombrado jefe del ejército constitucionalista. El poder Ejecutivo de la Unión y la Cámara de Diputados lo nombraron presidente constitucional de la República.

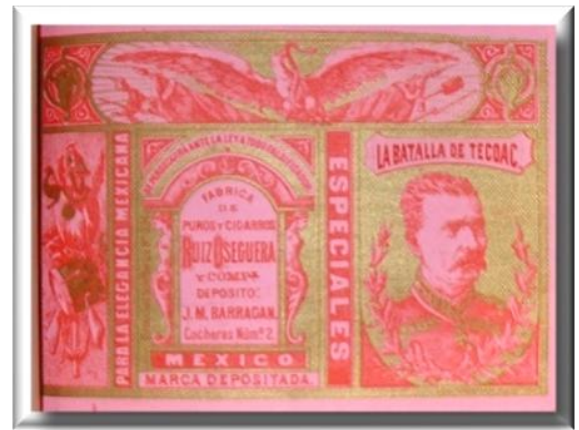

Figura197 "La Batalla de Tecoac". Para la elegancia mexicana.

Se perseguirá ante la ley a todo falsificador-

Fábrica de puros y cigarros Ruiz Oseguera y Comp.

Depósito J.M: Barragán Cocheras Núm. 2 México. 
El gobierno de Don Porfirio, fue de "mano dura" en 1879, según cuentan, mandó un telegrama al Gobernador de Veracruz Luis Mier y Terán que decía "mátalos en caliente" autorizando (de alguna forma) la ejecución de nueve lerdistas que conspiraban contra su gobierno.

Irónicamente, Díaz tenía una vida de altibajos, momentos sumamente emocionales: debía ser concentrado y fuerte, para poder equilibrar su vida cotidiana, familiar y política. Por ejemplo: Ante la enfermedad mortal de su mujer, Delfina Ortega y para que ella pudiera recibir la absolución, debían casarse canónicamente, para lo cual Díaz debía retractarse de sus prácticas masónicas y de haber jurado la Constitución del 57 . Una vez cumplidos estos requisitos, se casó con Delfina Ortega, quien falleció al día siguiente. Porfirio Díaz fue nombrado Secretario de Fomento, durante su gestión inauguró el primer tramo del ferrocarril Matamoros-Monterrey.

Otra etiqueta curiosa se refiere a un apartado de la vida de Manuel González, lo llamaban el Manco fue un hombre audaz, herido al menos en diecisiete ocasiones. Tenía una marca permanente en su rostro daba testimonio de la "caricia" recibida por la afilada hoja de un sable. Sin embargo a la hora del combate nunca se arredró. Manuel González era un hombre "hecho para la guerra". Durante la guerra de intervención y el imperio (1862-1867) su destino coincidió con el de otro hombre de armas, cuya carrera iba en franco ascenso: Porfirio Díaz.

El general oaxaqueño quedó gratamente impresionado por las dotes de buen jinete que mostraba González y lo incorporó a sus filas. En poco tiempo era el jefe de su estado mayor. A partir de 
entonces los dos hombres forjaron una estrecha amistad sellada con un promisorio compadrazgo. Durante el asalto republicano a la ciudad de Puebla el 2 de abril de 1867 don Manuel perdió el brazo derecho. Nueve años después, debido a su oportuna intervención en la batalla de Tecoac y a pesar de haber sido herido en el muñón, González abrió las puertas de la presidencia a Porfirio Díaz, quien le agradeció el gesto entregándole el Ministerio de Guerra y en 1880 la Presidencia de la república.

\begin{abstract}
"Se sobreponía en él -escribió Justo Sierra- no sé qué espíritu de aventura y de conquista que llevaba incorporado en su sangre española y que se había fomentado en más de veinte años de incesante brega militar en que había derrochado su sangre y su bravura. El general González es un ejemplar de atavismo: así debieron ser los compañeros de Cortés; física y moralmente así. De temple heroico, capaces de altas acciones y de concupiscencias soberbias, lo que habían conquistado era suyo y se erizaban altivos y sañudos ante el monarca, para disputar su derecho y el precio de su sangre. El presidente creía haber conquistado a ese precio, en los campos de Tecoac, el puesto en que se hallaba; era suyo y lo explotaba a su guisa".
\end{abstract}

Aunque su elección como jefe del poder ejecutivo se verificó guardando todas las formas constitucionales, en la mentalidad del guerrero tamaulipeco el poder era una más de sus conquistas; otra plaza tomada luego del asedio, una batalla ganada. Su administración fue un desastre, agravada en gran medida por los ataques infundados de sus enemigos, azuzados por su propio compadre Díaz para evitar que le tomara gusto a la Presidencia. Sin embargo, entre "dimes y diretes", González aprovechó el cargo para amasar una buena fortuna. A unos meses de entregar la Presidencia, en 1883, el general compró las casi 13 mil hectáreas que conformaban entonces la hacienda de Chapingo. 


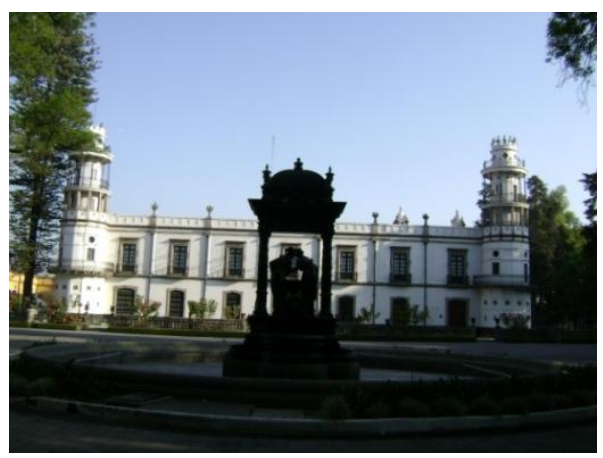

Figura 198 Fuente de las Ciracianas y casa principal de la Hacienda de Chapingo, hoy Universidad Autónoma de Chapingo. México, Texcoco, Edo de México.

Fotografía L. Mayagoitia 2008

Decían las "malas lenguas" que a raíz de la pérdida de su brazo don Manuel había desarrollado un desenfrenado apetito sexual, y para saciarlas mandó construir en Palacio Nacional una habitación contigua al jardín con una puerta secreta que daba a la calle por la que desfilaban decenas de mujeres dispuestas a entregarse al juego del poder, la seducción y el sexo. Con el tiempo el general ya no tenía la fogosidad de joven ${ }^{129}$. Escuchó entonces una historia que parecía surgida de la mitología. Se hablaba de unas mujeres que habitaban en Circasia, región caucásica de Rusia, que transpiraban pasión y sensualidad y cuya mayor virtud era la magia sexual que poseían. Nada había comparable en el mundo a una noche de pasión con una circasiana. El máximo placer jamás imaginado corría según decían, por las yemas de sus dedos, por su curvada cintura, por sus pechos firmes y sus caderas amplias, por su aroma convertido en elixir de amor.

\footnotetext{
${ }^{129}$ Silvia González Marín. Historia de la Hacienda de Chapingo. Universidad Autónoma de Chapingo, 1996 p. 169
} 


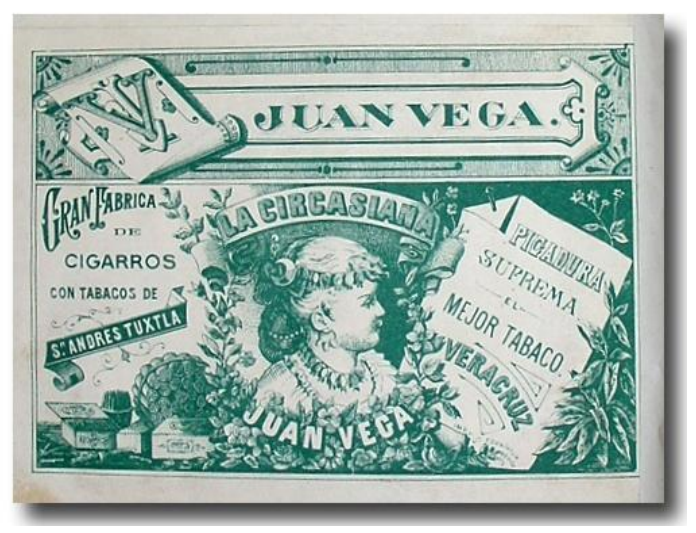

Figura 199 Registro de propiedad artística Gregorio Palacios y Cía, Fecha: 7 noviembre 1884. Firma Baranda, Registro de la Guía de la Academia de San Carlos 11010. Marca "La Circasiana". Litográfica La Española. Gran Fábrica de cigarros con tabacos de San Andrés Tuxtla. Picadura suprema. Juan Vega. El mejor tabaco Veracruz

"Ni tardo ni perezoso", don Manuel hizo los arreglos convenientes, envió por una de aquellas míticas mujeres y puso la hacienda de Chapingo a su entera disposición. Durante algún tiempo la misteriosa dama, a quien todos conocían como "la circasiana", fue ama y señora de la hacienda. Se paseaba por los jardines, caminaba por los corredores, era como una visión dentro de la hacienda, como un fantasma.

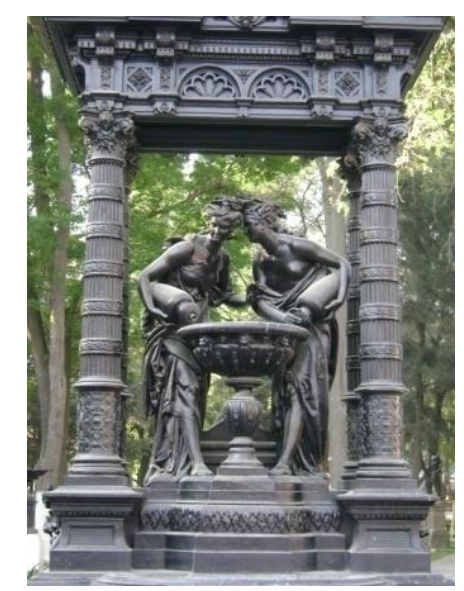

Figura 200 Fuente de las Circasianas. Hacienda de Chapingo, México, Texcoco, Edo. de México. Fotografía L. Mayagoitia febrero 2008 
Nadie se acercaba a ella y dejaba a su paso una estela de misterio. Cuando la visitaba el general, el tiempo y su vida dejaban de tener sentido. Tal fue su fascinación por aquella mujer, que el general ordenó la construcción de una fuente morisca conocida con el tiempo como "de las circasianas", para dejar testimonio de que en sus brazos llegó a conocer la gloria.

Porfirio Díaz había cumplido 52 años cuando se casó por segundas nupcias con Carmen Romero Rubio Casteló y en diciembre del mismo año protestó como gobernador del Estado de Oaxaca, en 1882 se separó del cargo para ir a la ciudad de México para apoyar a su amigo el Presidente Manuel González quien tenía grandes problemas.

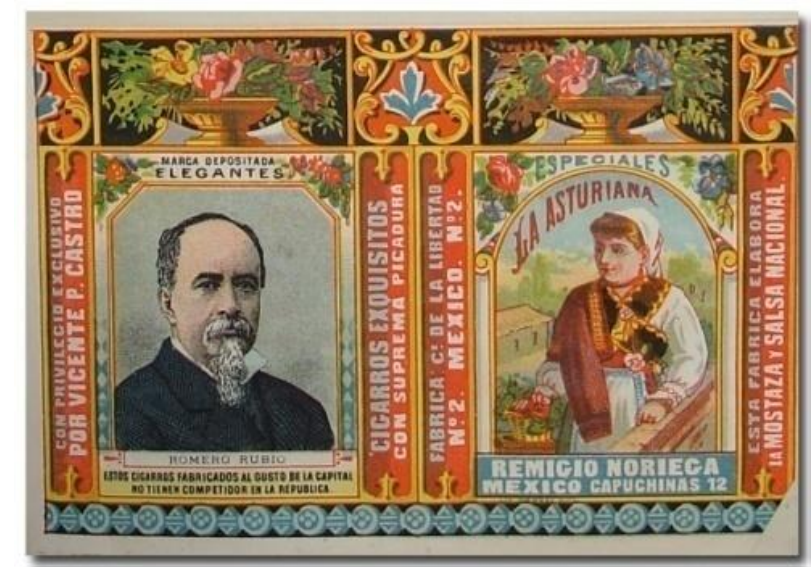

Figura 201 "Romero Rubio". Marca: La Asturiana. Marca depositada.

Elegantes Los cigarros fabricados al gusto de la capital no tienen comparación en la República. Especiales. Fábrica Calle de la Libertad No 2Remigio Noriega. México, Capuchinas 12.

Esta fábrica elabora la mostaza y salsa nacional.

Manuel Romero Rubio (Fig. 146) nació en la ciudad de México en 1828, ejerció como abogado desde 1854 y dos años después fue electo diputado al Congreso Constituyente. En 1857 combatió contra 
las fuerzas conservadoras, junto a Santos Degollado, luchó en Zacatecas como miembro de las tropas de Jesús González Ortega en 1859. Partícipe de numerosas victorias liberales volvió a ser elegido diputado. El 31 de agosto de 1876, el presidente Sebastián Lerdo de Tejada le designó Secretario de Relaciones Exteriores, cargo que abandonó tras el derrocamiento de Lerdo de Tejada en noviembre de ese año. Exiliado a Estados Unidos, regresó a México y fue electo senador. En 1882, su hija Carmen se casa con el entonces Secretario de Fomento, Porfirio Díaz quien al formar nuevamente gobierno en calidad de presidente, nombró a Romero Rubio Secretario de Gobernación en 1884. Falleció en la ciudad de México, el 21 de octubre de $1895 .^{130}$

En paralelo a los hechos nacionales podemos observar que los comerciantes de tabaco no manera desaprovechaban la oportunidad para publicitar sus productos relacionándolos con las bondades de los tabacos que vendían. Observamos la etiqueta La libertad y la en que se conjuntaban los dos factores:

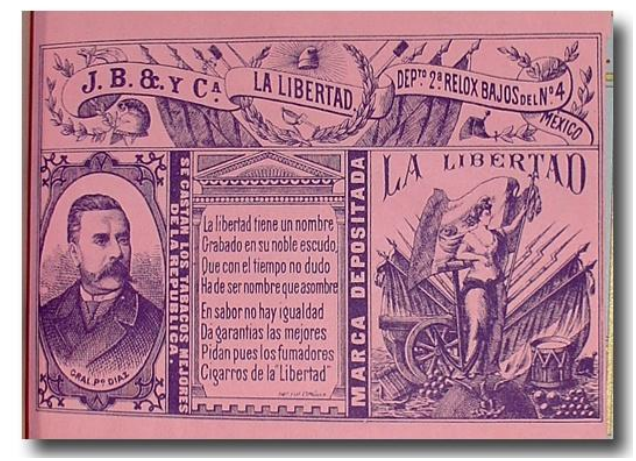

"La libertad tiene un nombre Grabado en su noble escudo Que con el tiempo no dudo Ha de ser nombre que asombre En sabor no hay igualdad Da garantías las mejores Pidan pues los fumadores Cigarros de la "Libertad".

Figura 202 "General Porfirio Díaz" Fábrica de tabacos La Fama, de Eusebio Castellanos. Fecha de registro de propiedad artística a favor de la Sra. Viuda de Castellanos,Nov.4, 1885 e hijos Tabaco superior de Compostela. Tepic. Registro en la Guía de la Academia de San Carlos 11061.

${ }^{130}$ Leduc Alberto, Op.Cit. Pp. 832-833 
En 1884 después de haber ganado su primera reelección Porfirio Díaz volvió a tomar protesta como presidente constitucional para el periodo 1884-1888. Su gestión por 30 años como Presidente de la República, fue la más larga en la historia de México.

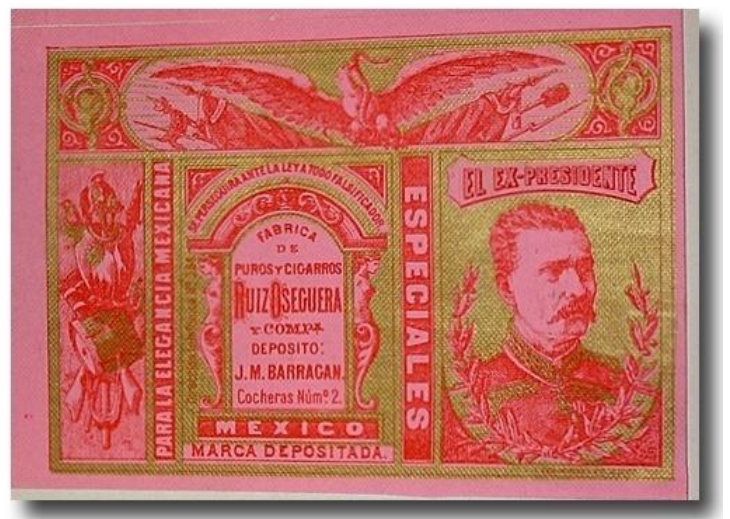

Figura 203 Marca "El Ex presidente" El Mejor tabaco del mundo. Papel sin igual. Depósito Calle Sto. Domingo No 9 México. Tabaquería La paz. Gran Fábrica de Cigarros Fernández y Bermejillo. Fecha de registro de propiedad artística 22 de mayo de 1884 a favor de Ruíz Oceguera. Firma Baranda. Registro de la Guía de la Academia de San Carlos 11010.Litográfica Moreau Hnos.

\subsection{LA PRODUCCIÓN DE TABACO DURANTE LA GESTIÓN DE DÍAZ}

Indudablemente la amplia gestión de Díaz permitió la continuidad de proyectos de toda clase: políticos, sociales, económicos, culturales etc. $\mathrm{Y}$ las expresiones artísticas no fueron la excepción, en el periodo que abarca nuestra investigación (1879 hasta 1902), nos referiremos a la tercera parte del porfiriato y particularmente a la parte de la historia que hace referencia al tabaco y a la litografía comercial específicamente etiquetas de cigarros y puros.

De 1877 a 1892 la producción de tabaco decreció: de 7504 toneladas pasó a 7116. En esos años el volumen exportado se incrementó 
hasta llegar a poco más del $2 \%$ de la producción, sin embargo el mercado interno permaneció estático. La industria del tabaco labrado era incipiente y el consumo interno fue bajando poco a poco por lo que las perspectivas de cultivo estaban dirigidas hacia el mercado externo. Otro problema evidente era la necesidad de contar con capital para ampliar y modernizar las fábricas porque los métodos de cultivo y beneficio del tabaco no eran eficientes. Los sembradores de tabaco se veían en la necesidad de vender a muy bajo precio sus cosechas, por lo que poco les interesaba la calidad del producto.

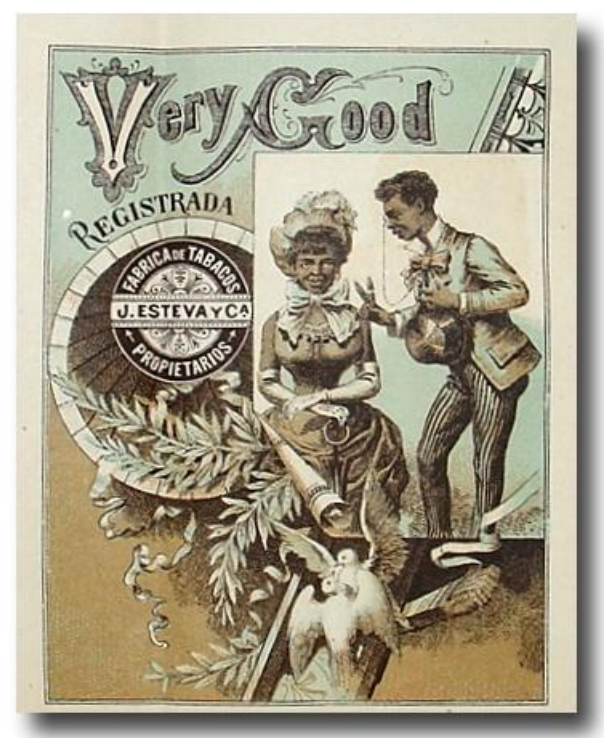

Figura 204 Fábrica de tabacos y registro de propiedad artística de Gregorio Palacios y Cía. Fecha: 27 julio 1887.Marca "Very Good". Registro en la Guía de la Academia de San Carlos 11065. Litográfica La Española.

En 1880 se creía a pesar de todo, que la supresión del estanco del tabaco, consumada por la Reforma, le abría grandes perspectivas, sobre todo en Veracruz, Tabasco, Campeche, Yucatán, Oaxaca y Tepic, cuando el tabaco cubano presentaba mucha mejor calidad y era más famoso. En otras regiones como Morelos, Michoacán, Guerrero, Colima, Sinaloa y Chiapas, la producción era creciente y 
se creyó que en poco tiempo las exportaciones crecerían significativamente, pero no fue así en el mercado externo, sino en el nacional.

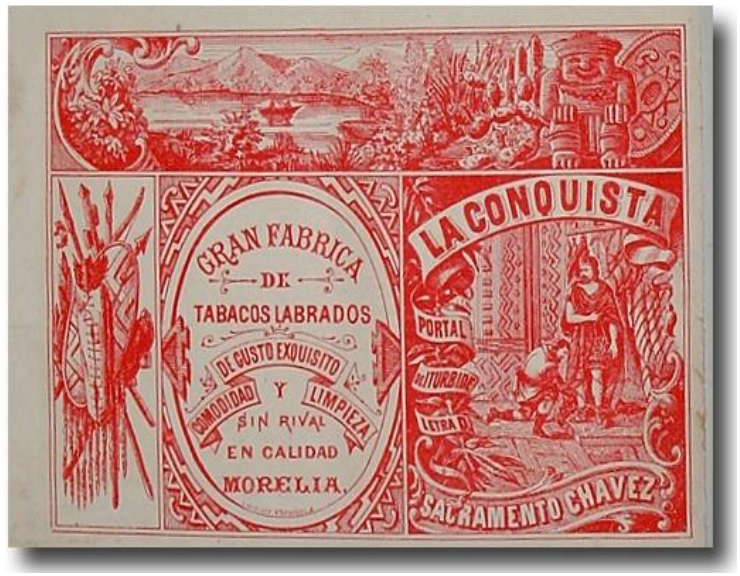

Figura 205 Gran Fábrica de Tabacos Labrados. Registro de propiedad Artística a favor de Gregorio Palacios y Cía. Fecha: 7 de noviembre de 1884. Firma Baranda, Registro de la Academia de San Carlos 11010.Gran fábrica de tabacos labrados de gusto exquisito comodidad y limpieza sin rival en calidad. Sacramento Chávez. Morelia Portal de Iturbide letra D. Litográfica La Española.

Además de etiquetas de tabacos encontramos algunas etiquetas de cerillos en la que observamos además de una imagen religiosa, al centro una mujer vestida con un traje típico del Estado de Michoacán y es curiosa la imagen de lado derecho en la que encontramos una representación de una fábrica de cerillos totalmente artesanal

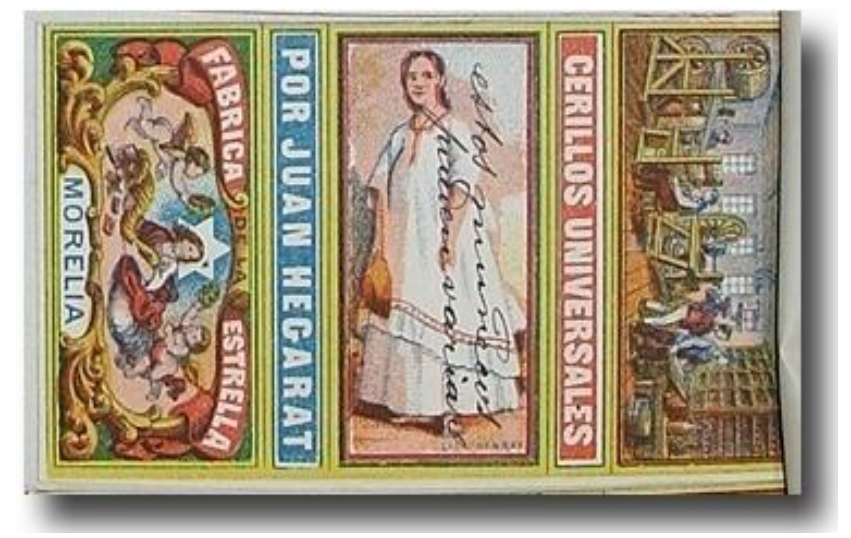

Figura 206 Fábrica "La estrella" Juan Hegart.

Cerillos Universales. Morelia 
Los cantones de Córdoba, Orizaba y Jalapa, eran productoras de tabaco sin embargo las tierras no tenían esta vocación de siembra por lo que los cultivos iban disminuyendo, así que se fue sembrando de manera más intensa en la zona sur del Estado y el norte y occidente de Oaxaca. Los primeros tabacos del sur de Veracruz que irrumpieron en el mercado fueron los de la cuenca del río San Juan, afluente del Papaloapan, los de San Andrés Tuxtla y Acayucan pronto adquirieron fama, a pesar de que su cultivo y preparación eran descuidados.

Pero continuamos con el tema de la producción de tabaco: En la península de Yucatán, en Tamaulipas y la costa de Oaxaca, Guerrero y Michoacán, se mantuvo la producción a pequeña escala. En tanto se procuraba aumentar el consumo y por tanto la producción, posiblemente para provocar en el consumidor un sentimiento de identidad con la marca de compra de ciertos cigarros, se diseñaban e imprimían algunas etiquetas que honraban a personajes célebres, es el caso de la etiqueta "La liga de la honradez" dedicada a Vicente Agüeros, Luis Guillén y Guillermo Prieto (fig. 207)

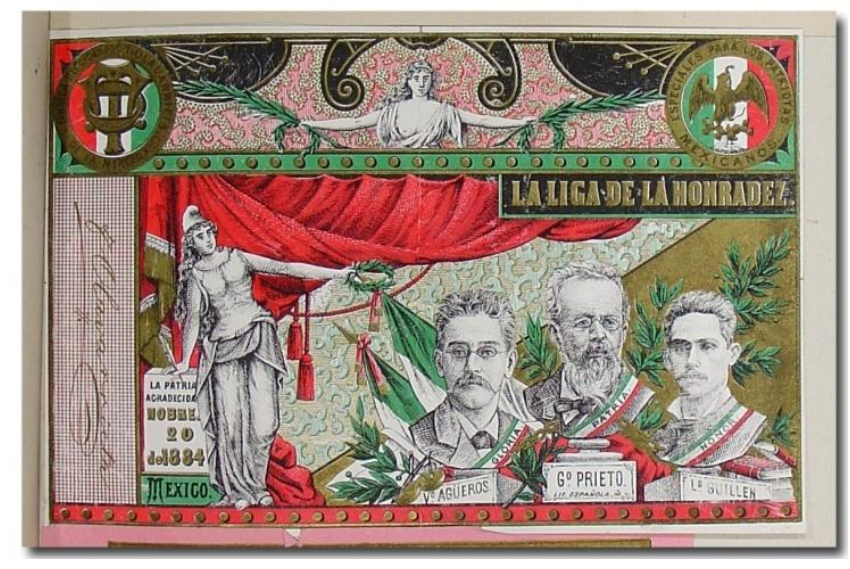

Figura 207 Etiqueta para cigarros: La Liga de la Honradez. Especiales para los patriotas mexicanos. Fábrica de C Olavarría México, La patria agradecida Noviembre 20 del 1884 


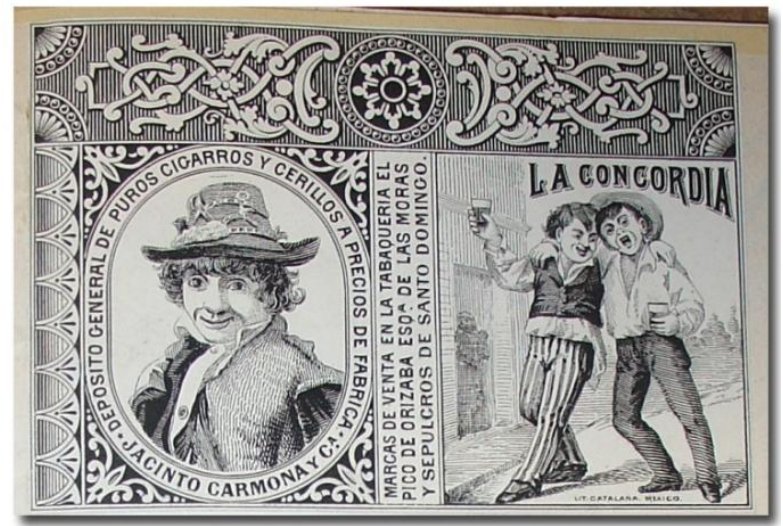

Figura 208 "La Concordia" Depósito de cigarros y cerillos a precios de fábrica. Jacinto Carmona. Marcas de venta en la tabaquería

El Pico de Orizaba Esq. De las Moras y Sepulcros de Santo Domingo Litográfica Catalana1885

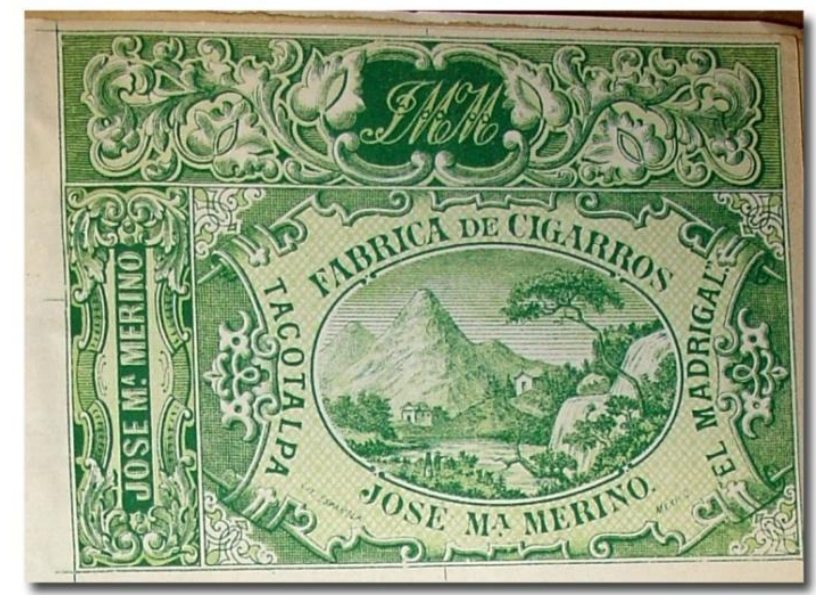

Figura 209 "El Madrigal” Fábrica de cigarros José María Merino, Tlacotalpa Litográfica Española, 1885

Ramón Balsa era de nacionalidad española, incursionó hacia la sierra oaxaqueña promoviendo el tabaco en el Valle Nacional. Su tabaco alcanzó un precio superior al de las famosas vegas cubanas de Vuelta Abajo en 1894. El Valle Nacional se pobló con rapidez de tabacos cubanos y canarios porque los campesinos podían comprar tierras baratas pagándolas a plazos por medio de la entrega de un tercio de la cosecha y la venta de otro tercio al propietario del terreno. En el cercano valle del río Santa Rosa, en Ojitlán, Veracruz, 
se extendió el cultivo y la última zona tabacalera importante fue la cuenca media del Tesechoacán cerca del Río Papaloapan y los alrededores de Playa Vicente. En 1890 en Veracruz se sustituyó la alcabala por el derecho sobre la producción, esto quería decir que la cuota que debía pagar cada productor tenía como base el rendimiento probable para cada tarea de 900 varas cuadradas; cuando el mercado se había cubierto, el producto podía circular por el territorio nacional libremente, para su venta al mejor precio de mercado.

El tabaco mexicano logró gran prestigio a partir del último decenio del siglo XIX y aún cuando no llenaba los requisitos internacionales de calidad de exportación, era bien aceptado en Europa y por sus bajos costos de producción y transporte competía con los tabacos cubanos y con los de Sumatra y Borneo.

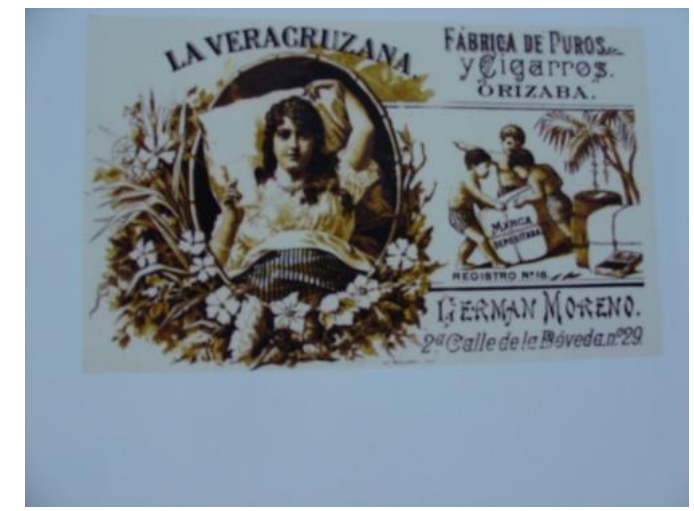

Figura 210 Imagen tomada de una piedra de la Academia de San Carlos, con separación de color. La imagen fue trabajada a partir de medios electrónicos Photoshop para lograr integración de color e impresión de la etiqueta. L. Mayagoitia. Academia de San Carlos 2003.

Algunos voceros del gobierno, particulares mexicanos, funcionarios y capitalistas extranjeros, recomendaban la formación de grandes 
compañías en México a semejanza de las europeas en colonias africanas 0 asiáticas y también colonizar tierras con vocación solanácea.

De 1892 a 1895 la producción nacional de tabaco aumentó de 7116 toneladas a 10777 ; en 1897 volvió al punto inicial. La exportación aumentó muy poquito debido a que la demanda interna consumía la nueva producción. El tabaco de la cuenca del Papaloapan tenía una posición firme en Europa, se vendía en Estados Unidos y presentaba avances en los mercados sudamericanos, sobre todo en Argentina, en donde la casa Balsa de Veracruz abrió una sucursal. Aparte del tabaco en rama, se hacían cigarrillos, cigarros y puros de fabricación especial que satisfacían el gusto de los fumadores alemanes.

Durante el porfiriato fue muy importante la producción de tabacos labrados en todos los estados de la república pero principalmente en Veracruz, Oaxaca y Nayarit se cosechaban fuertes cantidades de tabaco para abastecer a las principales fábricas del país. La industria del tabaco se mantuvo estancada de 1877 a 1892 , las exportaciones se redujeron por lo que el tabaco quedó disponible para las fábricas nacionales: 7400 toneladas de tabaco en rama en 1877 y solo 6000 en 1892. En México era común que hubiera una población de mediana importancia que contara con una manufactura de puros, picadura de tabaco preparada a mano o por operarios y el cigarrillo era envuelto en hoja de maíz o en fino papel catalán.

Al estimularse la economía del país por las crecientes facilidades de intercambio comercial, la industria del tabaco entró en franca 
expansión hacia 1890. Se instalaron fábricas modernas y mecanizadas y los cigarrillos engargolados de producción en masa desplazaron los de la hoja y redujeron el consumo de puros. Fue en el Distrito Federal en donde se instalaron las fábricas más grandes, a lo largo del porfiriato la producción fue de 23 millones de cajetillas anuales de 1877 a 1892 y luego se aceleró a 108 millones de 1898 a 1899 es decir aumentó cuatro veces y a 277 millones de cajetillas en 1910-1911. En todo el país la producción pasó de 328 a 493 millones de cajetillas entre ese año y 1910-1911 después de haber llegado a su cifra máxima en 1906-1907 que fue de 526 millones de cajetillas. Los puros iban siendo desplazados por los cigarrillos y su producción bajó de 110 millones de piezas (recortados y de perilla) en 1898-99 a 76 millones de piezas en 1910-1911. Sin embargo el hábito por fumar se propagó y se reflejó en el aumento de la cantidad media anual de tabaco labrado disponible en el país por habitante que fue de 470 gramos en 1900-1901 a 579 en 1910-1911 es decir a razón del 2.1\%. La situación mejor era para los tabacos de tipo medio, cuyos precios eran inferiores a los cubanos. La falta de brazos y de capitales, y el rezago técnico en el cultivo, parecían la causa principal del atraso.

\subsection{EL PAPEL}

La manufactura de papel para empaque e imprenta y subsidiariamente para escritorio se inició hasta 1840 coincidió con la expansión de la industria textil, por lo que hasta muchos años después se fue utilizando para forjar cigarrillos. En 1886 el papel importado costaba en el país 50 centavos más por resma que el de fabricación nacional debido a los aranceles. En 1878 existían siete fábricas de papel en el Valle de México, otra en Tlaxcala, y dos cerca 
de Guadalajara. Ocho años más tarde surgieron en Querétaro y en Valle de México, utilizaban principalmente los desperdicios de las fábricas de algodón, hilacha, papeles viejos, pajas de linaza y otros desechos las traperías eran empresas que se dedicaban a la recolección de estos materiales y participaban casi 5 mil personas. La industria del papel estaba sometida a la presión constante por parte de impresores y dueños de periódicos que pugnaban por la abolición del arancel que gravaba la entrada del papel extranjero. Poco a poco pudo aumentar la producción y su abasto. En gran parte el mercado era sobre todo de papel corriente.

En 1878 se produjeron 2 mil toneladas de papel, cifra que subió a 5750 en 1886. La producción anual por fábrica apenas 286 toneladas en 1878 y 480 en 1886 revela la escala limitada ${ }^{131}$. La industria papelera moderna surgió hasta 1892 con la Fábrica San Rafael en las estibaciones forestadas del Ixtaccihuatl, esta fábrica producía hacia el final del porfiriato, de 1888 a 1889 casi 20 mil toneladas anuales casi todo el papal era corriente y utilizado para el periódico. La Industria del las artes graficas descollaba por la calidad y diversidad de sus productos, no por su volumen.

\subsection{LA LITOGRAFÍA EN AUXILIO DE LA LABOR COMERCIAL.}

Durante el segundo tercio del siglo XIX, la litografía fue una técnica de impresión que tuvo una gran importancia en México, debido a la rapidez de impresión y el bajo costo. La litografía se caracteriza por el empleo, como matriz, de una piedra calcárea, conocida como piedra de arte litográfica, de Kolheim o piedra de Solenhofen (región

\footnotetext{
${ }^{131}$ Daniel Cosío Villegas, 1898-1976. Obra preparada por el Centro de Estudios Históricos. México, El Colegio de México, 1994 p. 365
} 
de Baviera junto con las riberas de los ríos Isar y Danubio). La caliza litográfica procede de los lechos fosilizados de vegetales, reptiles y moluscos marinos del periodo jurásico lo que reporta su alto contenido en carbonato de calcio $^{132}$. Tiene una estructura porosa y su grano es homogéneo, su composición química le da dureza y homogeneidad, la superficie granulada es sensible a algunas sustancias grasas y tiene cierta capacidad para retener la humedad (capacidad hidrófila). Las piedras eran cortadas con diversas dimensiones de ancho y alto pero el grosor casi constante de 8 a 10 $\mathrm{cm}$. Una vez extraídas de las canteras se labraban manualmente, propinando vigorosas cinceladas en las partes altas de los laterales y menos fuertes en la parte media, de esta forma la piedra tenía una pequeña curva en los cuatro lados que garantizaba estabilidad en la impresión. La operación se completaba con un abujardado en la parte media de los cuatro lados de la piedra que proporcionaba una textura ligeramente punteada.

El pulido de la piedra consiste en frotar arena más o menos fina entre dos piedras añadiendo agua periódicamente para que la piedra trabaje de forma húmeda algunos litógrafos utilizan carborundum, un compuesto de gran dureza, en diferentes granos, que actúa como abrasivo ${ }^{133}$ su mezcla con la arenilla del desgaste de la piedra lo convierte en un medio menos agresivo, el grosor del carborundo y la fricción de las piedras se realizan en razón del graneado que se desea obtener en la superficie de la piedra que se va a dibujar.

La extracción de las piedras continuó hasta la primera mitad del siglo XX y en México algunas piedras fueron extraídas de

\footnotetext{
${ }^{132}$ Lidón, Op. Cit p 215

${ }^{133} \mathrm{http}: / /$ en.wikipedia.org/wiki/Silicon_carbide
} 
canteras del Estado de Puebla, su color es amarillento y tienden a desquebrajarse fácilmente. Al irse incorporando las planchas metálicas en los talleres litográficos el uso de piedras litográficas concluyó.

Hay diversos tipos de piedras ${ }^{134}$ cuyos colores de acuerdo con el porcentaje que tengan de hierro, alúmina, sílice y de acuerdo con el porcentaje de carbonato de calcio:

\begin{tabular}{|c|c|c|c|c|c|c|c|}
\hline \multicolumn{8}{|c|}{ Tipos de piedras } \\
\hline $\begin{array}{l}\text { Blanco a } \\
\text { amarillo }\end{array}$ & $\begin{array}{l}\text { Bajo } \\
\text { contenido de } \\
\text { óxido de } \\
\text { hierro } \\
\text { alúmina y } \\
\text { sílice Alto } \\
\text { porcentaje } \\
\text { de carbonato } \\
\text { de calcio }\end{array}$ & $\begin{array}{l}\text { Grano } \\
\text { grueso No } \\
\text { permiten } \\
\text { graneado } \\
\text { demasiado } \\
\text { fino }\end{array}$ & $\begin{array}{l}\text { Caliza } \\
\text { blanda } \\
\text { Poco } \\
\text { compacta }\end{array}$ & $\begin{array}{l}\text { Muy } \\
\text { hidrófila }\end{array}$ & $\begin{array}{lr}\text { Receptiva } & \text { a } \\
\text { sustancias } & \\
\text { grasas } & \text { de } \\
\text { tintas } & \text { de } \\
\text { dibujo } & \text { e } \\
\text { impresión } & \end{array}$ & $\begin{array}{l}\text { Requieren } \\
\text { perfecto } \\
\text { apomazado }\end{array}$ & $\begin{array}{l}\text { Para dibujo } \\
\text { a lápiz y } \\
\text { superficies } \\
\text { planas de } \\
\text { color }\end{array}$ \\
\hline $\begin{array}{l}\text { Ocre a } \\
\text { gris } \\
\text { obscuro }\end{array}$ & & $\begin{array}{l}\text { Grano fino, } \\
\text { compacto y } \\
\text { uniforme }\end{array}$ & $\begin{array}{l}\text { Porosa } \\
\text { pero } \\
\text { compacta }\end{array}$ & & & & $\begin{array}{l}\text { Son las } \\
\text { más usadas } \\
\text { en } \\
\text { litografía, } \\
\text { también } \\
\text { como } \\
\text { matrices de } \\
\text { impresión }\end{array}$ \\
\hline $\begin{array}{l}\text { Azul a } \\
\text { azul } \\
\text { pizarroso }\end{array}$ & $\begin{array}{l}\text { Contiene } \\
\text { óxido } \\
\text { férrico }\end{array}$ & & $\begin{array}{l}\text { Caliza } \\
\text { más dura } \\
\text { Porosa } \\
\text { muy } \\
\text { compacta }\end{array}$ & $\begin{array}{l}\text { Menos } \\
\text { hidrófilas }\end{array}$ & $\begin{array}{l}\text { Menos } \\
\text { absorbentes } \\
\text { de sustancias } \\
\text { grasas }\end{array}$ & & $\begin{array}{l}\text { Para } \\
\text { imágenes } \\
\text { de alta } \\
\text { definición, } \\
\text { con } \\
\text { detalles } \\
\text { exquisitos }\end{array}$ \\
\hline
\end{tabular}

Figura 211 Tipos de piedras.

Para acondicionar las piedras se realizan tres operaciones:

1. Graneado. Su objetivo es eliminar la imagen que pudiera tener dibujada o grabada la piedra y dejar uniforme la superficie con buena porosidad para el dibujo que se va a realizar. Las piedras se granean como lo indicamos anteriormente, colocando sobre la superficie de una piedra carborundo y agua después se coloca otra 
piedra con la que se hacen movimientos en forma de ocho, las piedras muy grandes se granean con un borriquete ${ }^{135}$.

2. Biselado. Esta acción se realiza en los bordes de la piedra, utilizando una lima su objetivo es suavizarlos y redondearlos para evitar que recojan tinta o marquen el papel de impresión ${ }^{136}$.

3. Apomazado. La piedra una vez graneada se frota con una piedra pómez húmeda con una solución de sal de acederas o piedra de alumbre en proporción de $200 \mathrm{gr}$ por litro de agua corriente, se deja actuar y después de 10 minutos la piedra queda satinada y brillante ${ }^{137}$.

Una vez que la técnica litográfica mejoró, las imágenes impresas eran coloreadas o iluminadas a mano artesanalmente, pero considero que desde que los litógrafos empezaron a utilizar la técnica pensaron en imprimir con colores. Como mencionamos Godefroy Engelmann (1788-1839) inventó el sistema para realizar litografías a color y en enero de 1837 registró una patente de intención por un nuevo procedimiento de impresión en colores sobre piedra que llamó cromolitografía ${ }^{138}$. A continuación realizaré una breve descripción de esta técnica.

El artista dibuja una imagen que corresponda al color que quiere obtener al imprimir una imagen final, es decir descompone el dibujo en tantas partes como colores desea utilizar dibujándolo en una piedra por cada color de tinta que quiera utilizar y sobrepone el

\footnotetext{
${ }^{135}$ Ibidem 221-222

${ }^{136}$ Ibíd. 223

${ }^{137}$ Ibíd. p. 224

${ }^{138} \mathrm{http}: / / \mathrm{www} . j a b e r n i-c o l e c c i o n i s m o-v i t o l a s . c o m / 1 \mathrm{~A}, 4.2$-fundamentosde: consultado el 16 de abril de 2012
} 
mismo papel sobre cada una de las piedras que entinta con un color diferente. Al sobreponer dos tintas obtenemos el tercero: como ejemplo si utilizamos una tinta amarilla sobre una azul tendremos el verde y si sobreponemos la imagen en negro tendremos la cromolitografía.

La manera más sencilla para descomponer o separar los colores es realizando un calco a partir del dibujo original: trazando todos los segmentos de un solo color en el contorno de la imagen que deseamos utilizar así se realizan tantos calcos como colores y se traspasan cada color en una piedra diferente. La técnica cromolitográfica provocaba imágenes muy buenas con 8 o 10 piedras pero en algunas obras se utilizaron 20 ó 24 colores distintos y la misma cantidad de piedras

Para lograr una imagen más exacta es importante cuidar el registro que relaciona la imagen de la piedra con el lugar en que se coloca la hoja de papel. También debe considerarse que cada vez que coloca la hoja sobre la piedra y se imprime pasándola entre la prensa, la piedra se debe limpiar y entintar otra vez.

Es así como durante la segunda mitad del siglo XIX y principio del $X X$ en cualquier litográfica artística considerada de calidad para realizar una buena cromolitografía se utilizaban 15 ó veinte tintas de diversos colores. Se imprimían naipes, estampas, tarjetas postales, etiquetas y habilitaciones dirigidas a la pujante industria tabaquera, carteles publicitarios que se asociaron al desarrollo comercial evolucionando el arte de la publicidad. Jules Cheret (1836-1932) fue la primera persona en crear carteles de publicidad de naturaleza artística, adjuntó a la imagen un texto breve que permitía una lectura rápida, mayor atención y comprensión del mensaje que se deseaba 
transmitir, comprendió la dimensión psicológica de la publicidad creando carteles con base en la seducción y el impacto emocional.

Como resultado las mejores marcas incorporaron etiquetas litográficas a sus productos diseñados y dibujados por los mejores artistas del momento como Alphonse Mucha para las Galletas Lu; el Champagne Ruinat, Champagne Moet Chandon; las perfumerías parisinas Roger \& Gallet, etc. y como lo observamos en capítulos anteriores, la litografía estuvo estrechamente ligada a la prensa escrita y fue el medio más utilizado para ilustrar libros.

En la última década del siglo XIX a partir de que utilizaron el color, los litógrafos incorporaron a la cromolitografía dos efectos o complementos visuales innovadores: el relieve y el dorado que dieron realce, realismo y belleza de sus obras. Louis Prang en Estados Unidos aportó el realce del dibujo como sensación de movimiento o pincelada y también se incorporaron efectos tridimensionales aplicando a la piedra o matriz pequeños puntitos más o menos abigarrados que provocan en el espectador efectos de sombra.

El relieve o realzado tenía como objetivo dar mayor efecto tridimensional a la imagen. Se aplicaba en orlas, adornos y algunas otras partes de la composición, para lograrlo se utilizaban dos troqueles: macho y hembra entre los que se colocaba la estampa ejerciendo una presión fuerte. El dorado se conseguía aplicando tintas metálicas, purpurina, polvo de cobre o una fina lamina de pan de oro. Con estos avances y mejoras la litografía llegó a presentar perfeccionamiento en la técnica y mayor realismo. 
Desde 1826 Linati había introducido la técnica en México con José María Herdia y Galli publicaron el periódico El Iris. Linati fue el primero que se ocupó en divulgar las costumbres civiles, militares y religiosas de México. Temas como el indio, el negro, los héroes nacionales, los cuadros de costumbres fueron litografiados y descritos por este autor ${ }^{139}$. Algunos artistas extranjeros también hicieron publicaciones que ilustraron a través de la técnica

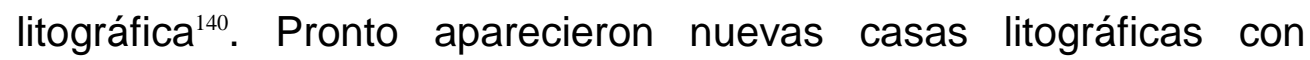
magníficos talleres como la de Víctor Debray en donde trabajó Casimiro Castro y A. Signone, los trabajos de esta editorial se consideraron más de fines mercantiles.

El taller de Ignacio Cumplido también realizó diversas obras litográficas como La Historia de la vida política y privada de Luis Felipe, de Alejandro Dumas y El Proceso de Pedro de Alvarado, trabajó también para revistas como "El Renacimiento" (1869) "El Artista" (1874) y en colaboración con Campillo ilustró Los Mexicanos pintados por sí mismos.

La caricatura tuvo un resurgimiento importante durante el siglo XIX con el avance de la litografía, el ingenio de los dibujantes se vio reflejado incluso en las cajetillas de cigarros y puros:

A las cromolitografías de la época del porfiriato les faltaba al principio, según los críticos "verdad en el colorido" aún cuando tenían el dibujo correcto, impresión limpia y aplicación de las tintas. En la capital funcionaban 33 imprentas entre las que sobresalían las de Ignacio Cumplido, Vicente García Torres y Escalante, Ramiro y Ponce de León y Dublán y Lozano además de las que tenían

\footnotetext{
${ }^{139}$ Claudio Linati. Costumbres civiles, militares y religiosas de México.

${ }^{140}$ Federico Waldeck, Ward, Mme. Calderón de la Barca, Thomas Egerton
} 

355 mil pesos en1878.

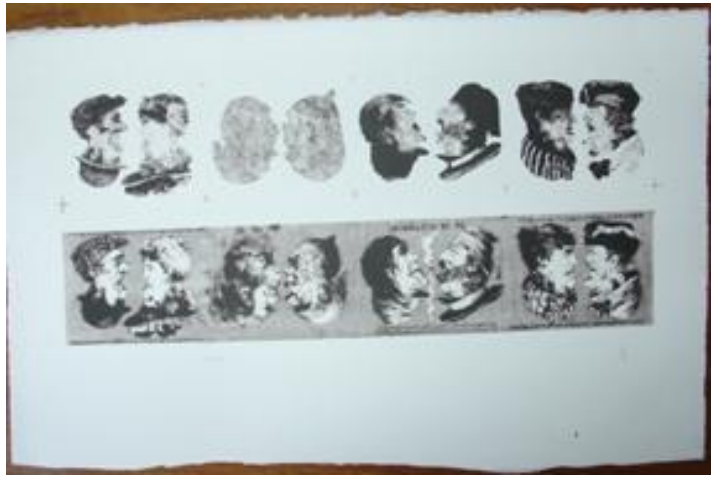

Figura 212 Litografía Impresa. Marca de cigarros De la Victoria. Imp ${ }^{\circ}$ Dra. Laura Mayagoitia, Academia de San Carlos, México 2003 (Con separación de colores)
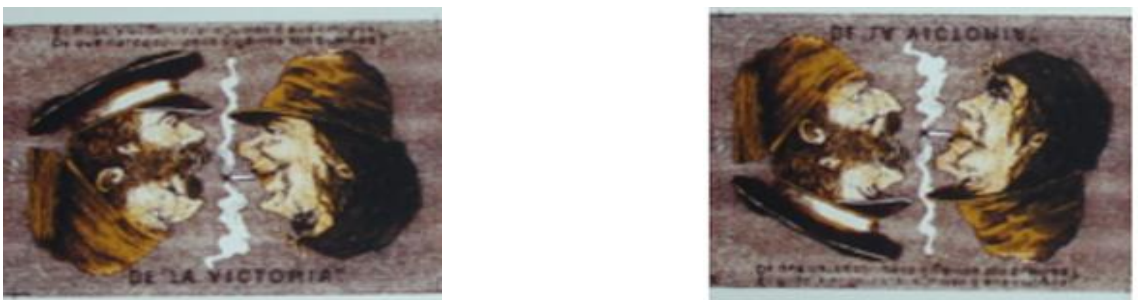

Figura 213 y 214. Litografía impreso por medios electrónicos.

Marca de cigarros La Victoria. Detalle. Diálogo: "El ruso y el turco preguntan a sus amigos de qué marca son esos cigarros tan buenos"

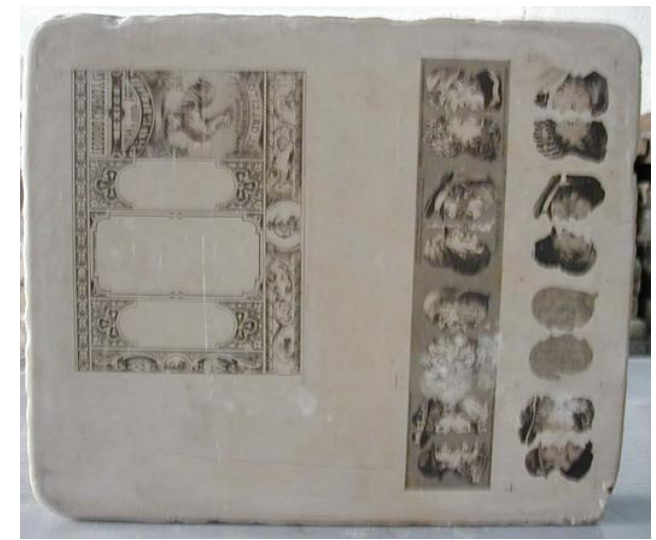

Figura 215 Piedra litográfica. ENAP

El número de personas ocupadas en las artes gráficas mexicanas aumentó de 5255 en 1895 a 6734 . En 1910 y al principio 
del nuevo siglo se formaron en la capital grandes establecimientos de imprenta para realizar trabajos comerciales y ediciones.

Estamos a punto de llegar al capítulo 5 en que presentamos el sistema de catalogación de etiquetas de tabacos y puros. 


\section{CAPITULO 5. DESCRIPCIÓN DEL SISTEMA DE CLASIFICACIÓN Y CATALOGACIÓN DE ETIQUETAS Y PIEDRAS LITOGRÁFICAS}

Con el objetivo de clasificar y catalogar la información relacionada con las etiquetas y piedras litográficas se diseñó y programó una base de datos en el sistema MS-Access. Dicho sistema permitió almacenar la información asociada a cada etiqueta y a cada piedra, así como la imagen digital de cada una. Aparentemente este capítulo es el más breve, sin embargo para poder estructurar el sistema de clasificación se requirieron muchas horas de trabajo de limpieza y catalogación de piedras y otras tantas de fotografía de piedras y etiquetas. El trabajo de gabinete que se utilizó para elaborar los cuadros de bases de datos y la misma organización del material se ven reflejados en el sistema de catalogación que tiene como objetivo ser posteriormente una fuente de consulta cotidiana para litógrafos, historiadores de arte y diseñadores gráficos. Estoy consciente de que los temas que he abordado pueden a partir de esta investigación ser profundizados en otros trabajos y abundar en el tema iconográfico e iconológico, pero en un principio es importante tener el material clasificado.

Fueron catalogadas 199 etiquetas de cigarros y puros del acervo Lino Picaseño y 90 imágenes de las piedras litográficas 
de la Escuela Nacional de Artes Plásticas plantel Academia de San Carlos de México.

A continuación describiré las características generales del sistema:

Se divide en dos secciones de catalogación, una para piedras y otra para etiquetas, y una tercera sección diseñada para almacenar los datos de configuración del sistema como son los nombres de los directorios donde se almacenan las imágenes digitales y la opción para generar copias de respaldo de la base de datos.

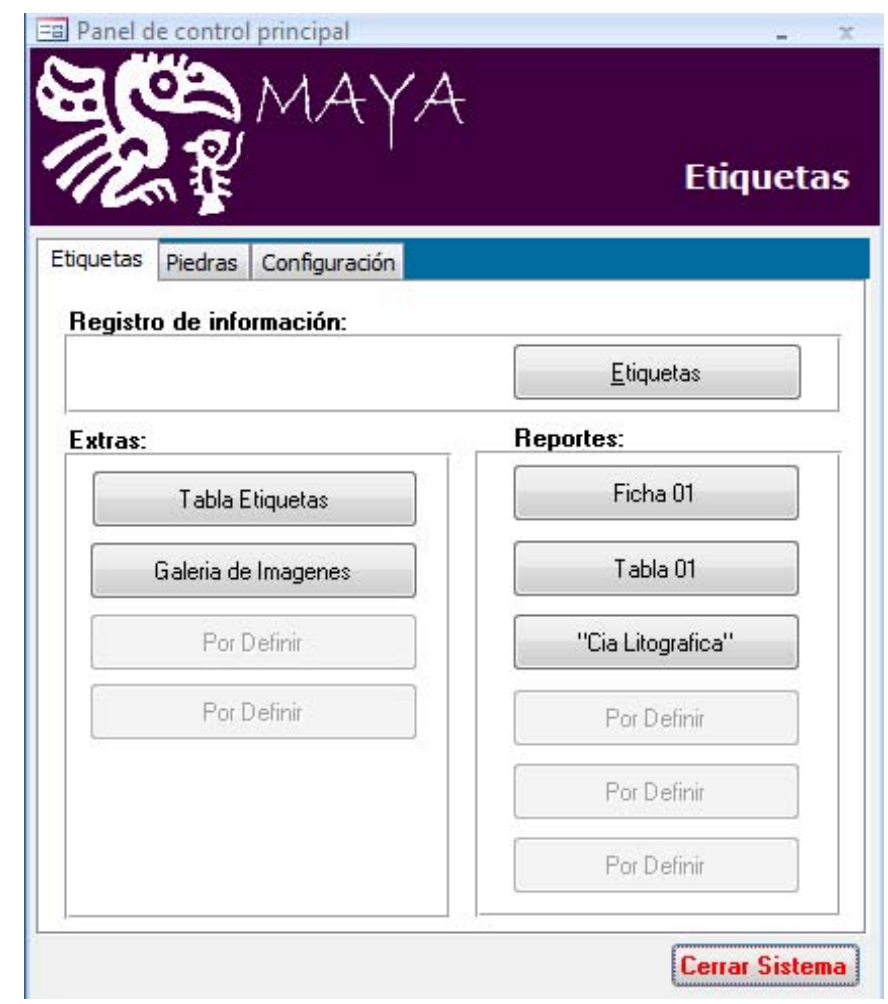

Figura 216 Pantalla inicial del sistema 
Tanto la sección de etiquetas como la de piedras contienen lo siguiente:

1. Fichas de captura y visualización de registros: En esta pantalla se muestran todos los campos que conforman la base de datos y que contienen la información de cada una de las etiquetas y/o piedras según sea el caso. Las funciones principales de esta pantalla son la de captura, edición y eliminación de registros.

2.

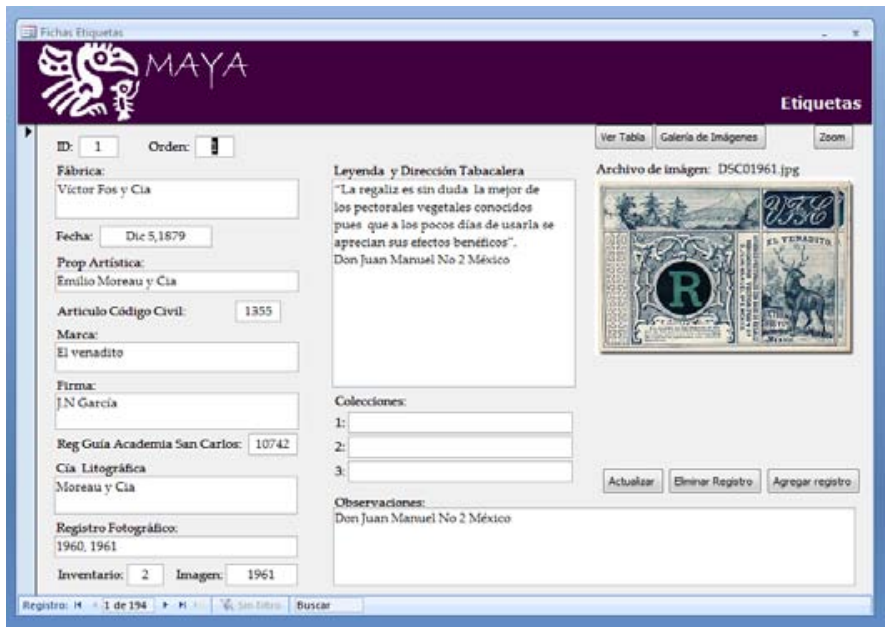

Figura 217 Ficha de captura y visualización de registros

3. Tabla general de información: Esta corresponde a una tabla tipo matriz en la que se presenta la información contenida en la base de datos. 


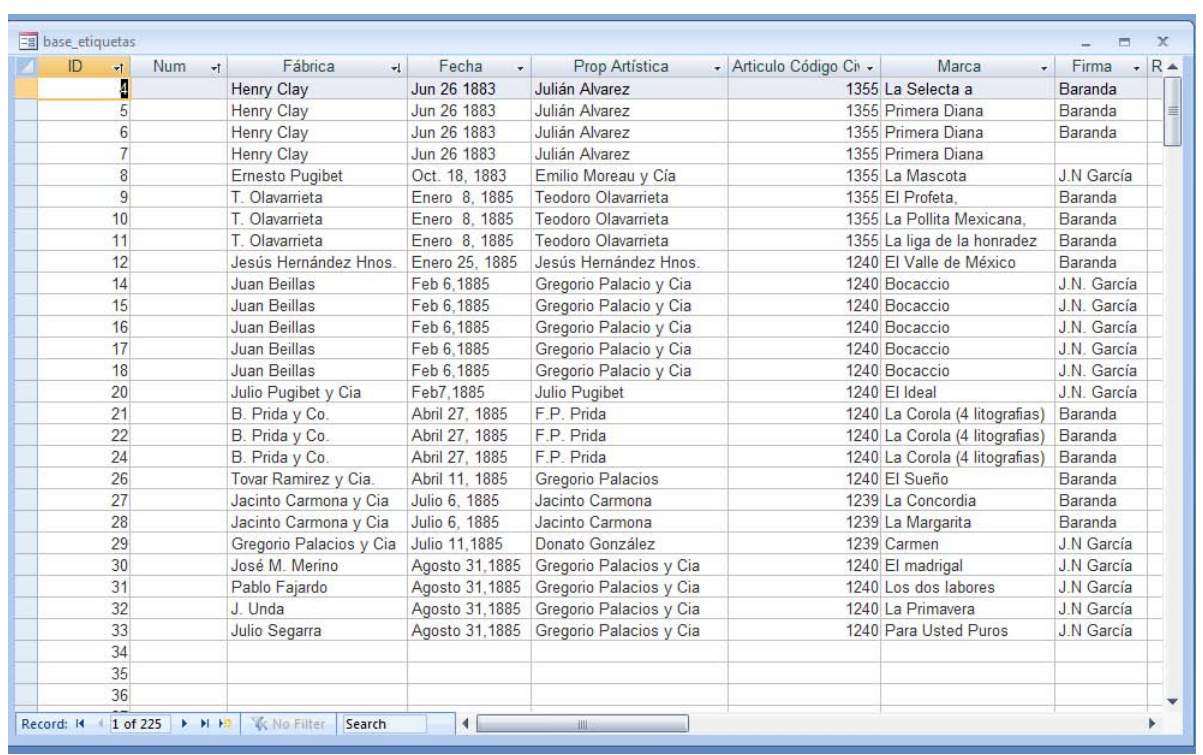

Figura 218 Tabla general de información

\section{Visualizador de imágenes: Ofrece la posibilidad de} observar cada una de las imágenes contenidas en la base de datos.

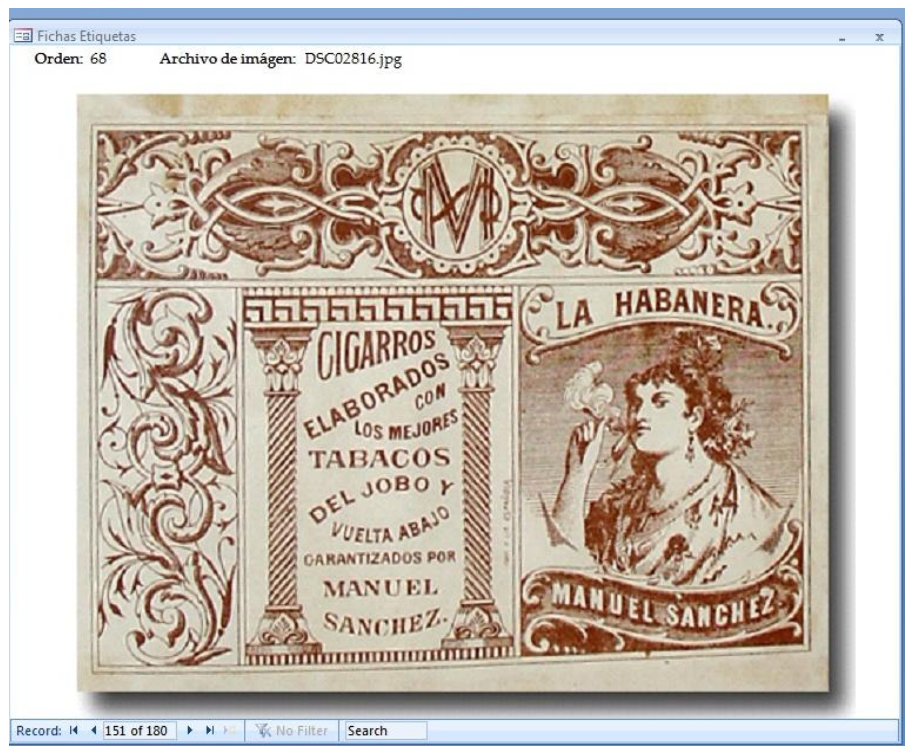

Figura 219: Tabla general de información 
5. Sub sección de reportes: En esta sección se presentan dos reportes prediseñados los cuales fungen como catálogos para impresión.

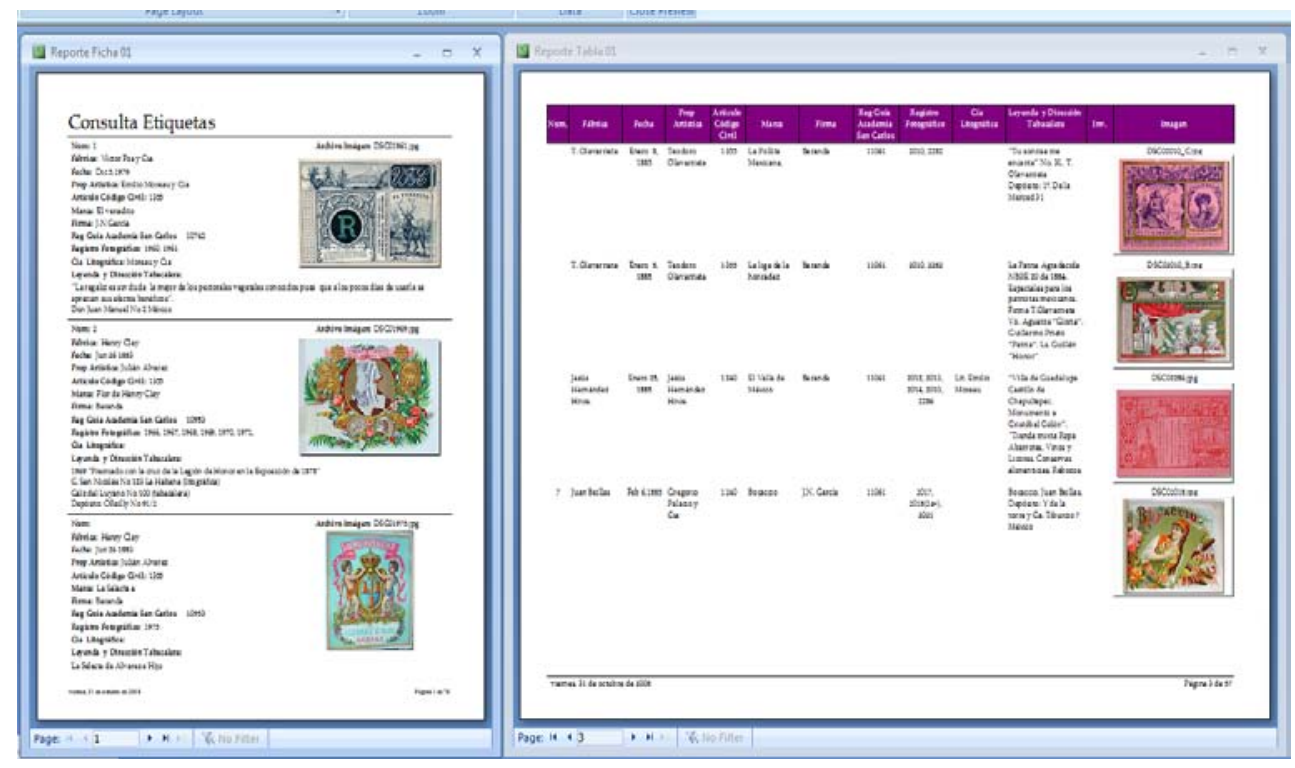

Figura220: Reportes

En adición se elaboraron imágenes en una base de Contact Sheet para poder obtenerlas rápidamente y copiarlas para la tesis.

El sistema de catalogación MAYA será compartido con la biblioteca de origen, es decir la Biblioteca Lino Picaseño de la Facultad de Arquitectura de la Universidad Nacional Autónoma de México.

Se ha programado también una última etapa de catalogación que será abordada en otro momento y es colocar en 


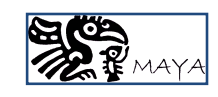

el sistema las fotografías que realicé de cada una de las hojas de los expedientes de Derechos de Autor que resguardan a cada una de las etiquetas y que se encuentran en el mismo acervo.

El Sistema se nombró MAYA y el logotipo se obtuvo de la imagen correspondiente a un sello olmeca, de barro cocido, plano, es la figura de un águila símbolo de la noche que tiene bajo el pico un ratón, este apunta con su pata delantera hacia el pico del águila en una peculiar postura que sugiere que el águila cierre el pico. El archivo del sistema por tanto se denomina; "Maya rata cierra el pico"

Con esta imagen termino mi presentación, para abordar las conclusiones.

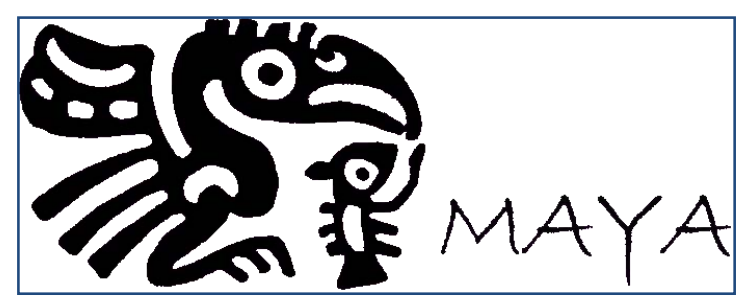

Figura 221 Impresión. Sello plano. Preclásico tardío, Veracruz, México. 
Reunir los temas tabaco y litografía nos ha conducido a estudiarlos en diversos contextos y abordar sus imágenes en códices prehispánicos que abundan en colorido, grabados en piedras litográficas y etiquetas diseñadas durante el final del siglo XIX a partir de la técnica litográfica.

La representación del tabaco en los códices Mesoamericanos (Borgia, Nuttal y otros) es recurrente, debido al sentido cósmico que establecían los hombres prehispánicos entre este producto y la deidad. En este aspecto, el humo del tabaco y su aroma eran elementos para agradar a las deidades y así obtener sus beneficios. En algunos códices, considerados como libros sagrados y en otros en los que se indica la genealogía de gobernantes se observa la importancia del uso del tabaco en rituales como entronización, matrimonios, nacimientos, funerales, etc. y en la vida cotidiana, algunas comunidades utilizaban el polvo del tabaco, las hojas o el humo como medicina o repelente. A diferencia del uso del tabaco como parte del rito, mito y medicina en las culturas mexicanas, ahora las compañías tabacaleras están obligadas por ley de advertir a los consumidores sobre el peligro que el consumo del tabaco en contra de su salud, se ha prohibido su uso en espacios cerrados, oficinas públicas, hospitales, universidades, y los restaurantes tienen áreas específicas para fumadores y no fumadores. 
El desarrollo de las etiquetas ha sido constante en el mundo, desde las etiquetas que se colocaban en vasos canopes, botellas, botes boticarios, hasta las sencillas cajetillas de cigarros o las elegantes cajitas de puros. En México antes de la conquista se acostumbraba colocar el tabaco en toles o calabazas, en las muñequeras de toles pequeños o piel de jaguar que fueron dibujadas en los códices prehispánicos. Esta costumbre se terminó un poco después de la conquista pero la tradición de empacar cigarritos de tabaco envueltos en hojas de maíz y amarrados con hilos de plantas de 20 en 20 forjados a mano, se conservó hasta entrado el siglo XX. México pasó por gobiernos nacionalistas que se regresaron la mirada hacia elementos de identidad prehispánicos que fueron utilizados en pinturas, diseños en textiles, o murales, pero a pesar de la importancia de la planta y su comercialización las representaciones gráficas del tabaco a partir de los códices no fueron utilizadas por las compañías tabacaleras, no encontramos imágenes de este tipo en las etiquetas del siglo XIX para publicitar tabacos y cigarros nacionales o de exportación.

Al final del siglo XIX y principio del XX la forja automatizada y el empaque de los cigarritos se hizo con hojas de papel sobre las que se colocaba una etiqueta litografiada. Posteriormente se diseñaron forjas de cigarros con papel fino en ocasiones de arroz, luego se introdujeron los filtros y los cigarros fueron acomodados en cajetillas de cartón con etiquetas modernas. Se envolvían con papel celofán, pero curiosamente la cantidad de cigarritos por caja se conservó. 
Al estudiar la historia de la litografía encontramos que entre España y México hubo caminos paralelos, pero asincrónicos en cuanto al desarrollo de la técnica. Mientras en España se divulgó en escritos publicados a partir de 1815 a México llegó hasta 1825 con Linati quien compartió sus conocimientos en el taller del Gral. Serrano en la entonces Academia de Bellas Artes de San Carlos en donde las imágenes para etiquetas algunas veces eran copiadas de originales españolas, alemanas 0 inglesas y otras transportadas a las piedras, desde imágenes impresas a partir de grabados en láminas de cobre. Al paso de los años la técnica litográfica se desarrolló, con fines comerciales, en empresas particulares.

Considero importante estudiar el desarrollo de la litografía en Cuba, y aun cuando no contamos con fuentes suficientes para hacerlo, de acuerdo a la bibliografía consultada, al iniciarse la revolución algunos empresarios españoles trasladaron sus compañías tabacaleras y litográficas a México para cultivar la planta e imprimir etiquetas para puros y cigarros. Debido a esta situación se produjeron sobre todo en marcas de puros finos, hermosas vitolas con imágenes de personajes mexicanos como Porfirio Díaz, Benito Juárez o empresarios tabacaleros como el General Carlos González.

Las imágenes de etiquetas grabadas sobre las piedras y las de la colección del Acervo Picaseño, nos proveyeron de material para abordar no solamente el desarrollo de la litografía, también el de la industria tabacalera y algunos episodios de la historia de mi nación por medio de imágenes de de gobernantes, héroes, próceres, 
batallas, mapas de la ciudad de México, fachadas de casas tabacaleras, modas, lugares pintorescos, etc.

El uso y consumo del tabaco han sido representados en novelas, pinturas, litografías como formas en que se expresaba aún de manera indirecta, la invitación a fumar o su crítica. La necesidad de comercializar el producto obligó a desarrollar estrategias de mercado y publicidad de acuerdo al tipo de consumidor a quien iba dirigida: mujeres, jóvenes, hombres, intelectuales, rebeldes, etc.

Los temas más recurrentes que los productores o dueños de las compañías tabacaleras o depósitos de tabaco utilizaban para asegurar el consumo era: reportar hechos notables, imágenes de hombres y mujeres destacados, lugares pintorescos, algunas costumbres, trajes típicos, fachadas de las fabricas de tabaco, o de las fincas tabacaleras, alegorías, mujeres elegantes, animales, plantas, jeroglíficos, historietas, etc.

Los distintos tipos de forja con diversos papeles o superficies como las hojas secas del maíz, el embalaje en las calabazas huecas, muñequeras y después el acomodo de puros dentro de cajitas de cedro que se metían para ser transportadas en cajones de pino, propició el diseño de etiquetas comerciales que provocaron la asociación tabaco con la litografía, logrando que las dos empresas se desarrollaran. Estas circunstancias junto con junto con el registro y protección de las marcas desde el siglo XIX, obligaron a distinguir un mejor producto de otro y una marca mejor de otra buena. El cultivo y comercialización del tabaco ha subsistido desde tiempos 
ancestrales aun ante las dificultades en los procesos de siembra, cultivo, cosecha, beneficio y comercialización, sin embargo han permanecido activos los cultivos extensivos y el dibujo de imágenes para las cajetillas de cigarros ha variado hasta llegar a modernas etiquetas con diseños sencillos considerados subliminales. Actualmente se tiene cuidado con la ortografía en las leyendas de las etiquetas, cosa que no sucedía durante el siglo XIX, por lo menos en México, en donde una gran parte de la población era analfabeta y los litógrafos tenían un grado escolar elemental.

El trabajo de investigación tuvo algunas limitaciones, nos fue imposible obtener permiso para separar las etiquetas de los expedientes y tomar un mejor registro fotográfico, sin embargo pudimos mejorarlas por medios digitales. También imprimir una selección de piedras con imágenes dibujadas y grabadas pertenecientes al acervo de la Academia de San Carlos de México que esperan ser expuestas.

Con este trabajo de investigación he conseguido:

Realizar la labor de limpieza y conservación de las piedras del acervo de la Academia de San Carlos de México e influir ante las autoridades de la Escuela Nacional de Artes Plásticas para que la colección sea conservada.

Estampar en papel guarro libre de ácido, una colección de imágenes representativa de este acervo. 
Realizar el análisis pormenorizado de la colección que se conserva en la Biblioteca de la Facultad de Arquitectura de la UNAM en el acervo "Lino Picaseño".

Realización de un video que posteriormente será editado

Realizar una catalogación digital

Exponer la importancia de la relación entre el tabaco y la litografía en México.

Las obras relacionadas con el tema de investigación coinciden en que las etiquetas litográficas en torno al tema del tabaco en España y México durante el siglo XIX y principio del XX estaban diseñadas conforme a los cánones del romanticismo, cuestión que es digna de ser abordada en otra investigación, así como el estudio iconográfico e iconológico de las imágenes que ahora presentamos en un sistema digital.

Esta investigación motivó a algunos alumnos de la Escuela Nacional de Artes Plásticas para participar en la limpieza y conservación del acervo litográfico y otros están realizando investigaciones para sus tesis de licenciatura y maestría en diseño. Sería recomendable que la Universidad Nacional Autónoma de México considerara la apertura de líneas de investigación que provoquen la conservación y difusión de los materiales relacionados con el tema de las etiquetas impresas y las imágenes que se conservan dibujadas y grabadas en las piedras calcáreas. 
He gestionado la exposición de la selección de litografías con la Asociación Autónoma del Personal Académico de la Universidad nacional Autónoma de México; British American Tobacco y el Museo Arcadio Pagaza en Valle de Bravo, Estado de México.

No pretendo cerrar aquí el trabajo de investigación sobre este apasionante tema. El que ahora presento intenta ser la base para futuras investigaciones personales y al mismo tiempo una vía para otros investigadores. 


\section{Documentos Consultados}

\section{Libro}

AJOFRÍN, Francisco de. Diario del viaje que hicimos a México fray Francisco de Ajofrín y fray Fermín de Olite, capuchinos. México, Ed. Antigua Librería Robredo, de José Porrúa e hijos, 1936.

ALCINA, Franch, José Miguel León Portilla, et. Al. Azteca-Mexica. Las culturas de México Antiguo, México, INAH, 1992.

AMERLICK, Ma. Concepción, Silvia del Amo Rodríguez et. al. Historia y cultura del tabaco en México. México, ed. Tabamex- Secretaria de Agricultura y Ganadería, 1985.

ANDER EGG, Ezequiel. Técnicas de Investigación Social. Argentina, Lumen, 1995

ANTREASIAN, Garo. The Tamarind Book of Lithograph, Art and Techniques. N. York, H.N. Abrams, 1971

ANTUNEZ Madrigal, Francisco. Primicias litográficas del Grabador José Guadalupe Posada. México (Aguascalientes) Ediciones Rana-Instituto Cultural de Aguascalientes, 1952.

ANTUÑANO, Esteban. Ventajas politicas, civiles, fabriles y domésticas que por dar ocupación también a las mujeres en las fábricas de maquinaria moderna están levantando en México, deben recibirse. Puebla, Hospital de san Pedro, 1837

Archivo General de la Nación. De oficio Tabaqueros Cigarros de la Tabacalera Mexicana. Museo Nacional de la Revolución.

Archivo Olavarría y Ferrari. Álbum de cajetillas de cigarros El Buen Tono. (Álbum de cajetillas de cigarros El Buen Tono 185 cajetillas). México, UNAM Biblioteca Nacional, 1985

BORBOLLA, Rubin de la. Atlas del tabaco en México. México, Ed. Tabacos Mexicanos, 1989.

BUNGE, Mario. La investigación científica. México, Siglo XXI, 2004

CAMACHO Morfín, Thelma. Imágenes de México. Las historietas de el Buen Tono de Juan B. Urrutia 1909-1912. México, Instituto Mora, Colección Historia Social y Cultural, 2002

CAREY, Frances and Anthony, Griffiths. From Manet to Toulouse-Lautrec French Lithogrphs 1860-1900. London, British Museum Publications. 1978

CASAS, Bartolomé de las. Historia de las Indias México. México, Ed. Imprenta y Litografía de Ireneo Paz, 1877.

CATHERWOOD, Frederick. Visión del Mundo Maya 1844. Int. Alberto Ruz Lhuillier. México, Ed. Privada de Cartón y Papel de México, 1977

CHAVEZ, R. Ángel El Tabaco. En: El Álbum Mexicano. Colección de paisajes, monumentos, costumbres y ciudades principales de la república mexicana 1875-1885; 1870-1879; Lit. Debray Sucs, C. Montauriol 
Códice Zouche Nuttal. (Ms. 39671 British Museum, Londres).Facsimilar México, Fondo de Cultura Económica, 19921

Códice Vaticano 3773. Un antiguo manuscrito en la Biblioteca Vaticana. Facsimilar México, FCE, 1963

CORONA Núñez, José. Mitología tarasca. Michoacán. 5a. ed. Instituto Michoacano de Cultura, 1906.

COSIO Villegas, Daniel. Historia Moderna de México. La República Restaurada. México, Hermes, 1956

COSIO Villegas, Daniel. Historia General de México. Obra preparada por el Centro de Estudios Históricos. México, Colmex, 1994

CUMPLIDO, Ignacio. El Álbum Mexicano. México, Imprenta de Ignacio Cumplido, 1848

DAWSON, John. Guía completa de grabado e impresión (Técnicas y materiales). España, H. Blume Editores, 1982

DIAZ del Castillo, Bernal. 1496-1584 Historia verdadera de la conquista de la Nueva-España. French. Paris: ed. Alphonse Lemerre, (Colección particular) 1877-1887

Diccionario de Arte y Artistas. Barcelona, Instituto Paramón Editores, 1968

DEANS Smith, Susan. Bureaucrats, planters, and workers: the making of the tobacco monopoly in Bourbon Mexico. Austin: University of Texas Press, 1992

DEBRAY, Víctor. El Álbum del Ferrocarril Mexicano. México, Papel y Cartón de México (Facsimilar) 1977

DÍAZ de León, Francisco. Juan B. Urrutia. Litógrafo y Apologista del Tabaco. México, Seminario de Cultura Mexicana, 1971

El álbum mexicano. Periódico de literatura y bellas artes. México, Imprenta de Ignacio Cumplido, 1849

El Renacimiento. Periódico literario. México, 1869, México, UNAM, Edición Facsimilar, 1993

EDITORIAL DEL VALLE DE MEXICO. México y sus alrededores. Edición facsimilar de la que fue realizada por los establecimientos Litográficos de Decaen en México, 1855-1856. México, Editorial del Valle de México, 1972

ESCUDERO M, Ignacio. Apuntes Históricos de la Carrera Militar del Señor General Porfirio Díaz. Presidente de la República Mexicana. México, Cosmos, 1975

ESTEVE Botey, Francisco. Historia del Grabado, Madrid, Labor, 1997

ESCALANTE, Ignacio. La naturaleza. Periódico científico, Segunda Serie, Tomo II 1891-1892-18931894-1895-1896. México, imprenta de Ignacio Escalante, Calle del Hospital Real, 1897

FATAS, Guillermo y Gonzalo M. Borrás. Diccionario de términos de Arte y elementos de Arqueología, Heráldica y Numismática. Madrid, Alianza Editorial, 1999 
FERNÁNDEZ, Justino. El Grabado en Lámina en la Academia de San Carlos durante el XIX. La Habana, Universidad de la Habana, 1938

FERNÁNDEZ, Justino. El Atlas de la obra de Bullok. En: Anales del IIE. México, UNAM, 1956

FERNANDEZ Ledezma, Enrique. Historia crítica de la tipografía en la ciudad de México, Impresos del siglo XIX. México, Ediciones del Palacio de Bellas Artes, 1991

FERNANDEZ Méndez, Eugenio. El Tabaco en Nuestra Historia. San Juan de Puerto Rico, First Book, 1997

FRANCES Erskine, Inglis (Mme. CALDERON de la Barca) La vida en México. México, Porrúa, 1959

HERNÁNDEZ Samperi, Roberto; Carlos Fernández Callado; Pilar Baptista Lucio. Metodología de la Investigación. México, Mc. Graw Hill, 2006

FLORESCANO, Enrique. Arma la Historia: La nación mexicana a través de dos siglos. México, Grijalbo, 2009

FLORESCANO, Enrique. Imágenes de la Patria. México, Taurus, 2005

FLORESCANO, Enrique. La bandera mexicana. Breve historia de su formación y simbolismo. México, Fondo de Cultura Económico, Colección popular, 2002

Fomento Cultural Banamex. Monumentos de México, Edición facsimilar de la que fue realizada por los establecimientos Massé y Decaen en México 1841. México, Fomento Cultural Banamex,1989

FUENTES Rojas, Elizabeth. Catálogo de los Archivos Documentales de la Academia de San Carlos (1900-1929). México UNAM-ENAP, 2000

GIMENEZ Caballero, Florencio y Manuel López Rodríguez. Cien Anillas de Calidad en la Litografía Tabacalera. Sevilla, Giralda, 1998

GONZÁLEZ Galván, Manuel. El tabaco y las cigarreras mexicanas de oro y plata. México. México ed. UNAM, Instituto de Investigaciones Estéticas, 1997

GONZÁLEZ Marín, Silvia. Historia de la Hacienda de Chapingo. México, Universidad Autónoma de Chapingo, 1996

GONZALEZ Sierra, José. Monopolio del Humo. Elementos para la historia del tabaco en México y algunos conflictos tabaqueros veracruzanos. Xalapa México, Universidad Veracruzana, 1977

HALE, Charles. El liberalismo mexicano en la época de Mora 1821-1853. México, Siglo XXI, 1972

HERNÁNDEZ, Francisco. Historia Natural de la Nueva España (escrita entre 1571 a 1576) México, UNAM, 1959

HUMBOLDT, Alejandro de. Ensayo Político sobre el Reino de la Nueva España. Tomo II Cap. X París. Casa de Rosa, 1822 
IRIARTE, Hesiquio. Los Mexicanos pintados por sí mismos. M. Murguía, 1855. Facsimilar México, Símbolo, 1946

IRVINS, William M. Imagen Impresa y conocimiento. Análisis de la imagen pre fotográfica. Barcelona, Gili, 1970

ITURRIAGA, José N. Litografía y grabado en México del XIX. México, Cálamo y Currente, 1993

LANDA, Diego de fray 1524-1579 Relación de las cosas de Yucatán. México. Ed. Pedro Robredo, 1938.

LEDUC, Alberto; Luis Lara y Prado et. al. Diccionario de Geografía, Historia y Biografía Mexicanas. México, Librería de la Vda. De C. Bouret, 1910

LENZ, Hans. Historia del papel en México y cosas relacionadas (1525-1950). México, Porrúa, 1990

LIEURE, J. La lithographie artistique et ses diverses techniques. Paris, Papyrus, 1939

LIDÓN Martínez, Concepción. La litografía industrial en el norte de España de 1800 a 1950 Aspectos históricos, estéticos y técnicos. Gijón Asturias, Trea. 2005

LINATI, Claudio. Trajes civiles militares y religiosos de México. Facsimilar México, Manuel Porrúa, 1979

LÓPEZ Linaje, Javier. Historia del Tabaco en España. Ministerio de agricultura, pesca y alimentación. Madrid, Cetarsa, 1999

MALTESE, Corrado (coordinador) Las técnicas artísticas. Italia, Manuales Arte Cátedra, 1973

MARQUÉS y Espejo, Antonio. Diccionario Feyjoniano, ó, Compendio metódico de varios conocimientos críticos, eruditos y curiosos: utilísimo al pueblo para quien le dispuso por orden alfabético. Madrid, Imprenta de la Calle de Capellane, $176 \mathrm{~s} / \mathrm{f}$

Massé y Decaén. Monumentos de México. Edición facsimilar de la que fue realizada por los establecimientos Massé y Decaen en México en 1841. México, Fomento Cultural Banamex, 1989

MATUTE, Álvaro. México en el Siglo XIX, Antología de fuentes e interpretaciones históricas. México, UNAM, 1973

MENDIETA, Gerónimo de (fray). Historia eclesiástica indiana 1525-1604] México, CONACULTA, 1997.

MONSIVAIS, Carlos. Guadalupe Jiménez Codinach, Fausto Ramírez et. al. Casimiro Castro y su taller. México, Fomento Cultural Banamex- Instituto Mexicano de Cultura. 2003

Los mexicanos pintados por sí mismos. México, Imprenta de Murguía y Cía., 1855

Museo Soumaya. Paisaje y otros parajes mexicanos del siglo XIX en la colección del Museo Soumaya. México, 1998

OBREGÓN Martínez, Arturo. "El Siglo XIX" en: María Concepción Amerlick et. al. Historia y Cultura en México, INAH, 1979. 
O'GORMAN, Edmundo y Justino Fernández. Documentos para la historia de la litografía en México. México, UNAM-IIE, 1955

ORTEGA Y Medina, Juan; Rosa Camelo et. al. Historiografía Mexicana. El surgimiento de la historiografía nacional. México, UNAM-IIH, 1997.

ORTíZ Gaitán, Julieta. Imágenes del Deseo. Arte y publicidad en la prensa ilustrada mexicana (18941939). México, UNAM, 2003

PESQUEIRA Olea, Eduardo. En: Historia y Cultura del Tabaco en México. México, Tabamex, 1985

RIVA PALACIO, Vicente. México a través de los siglos. Historia general y completa del desenvolvimiento social, político, religioso, militar, artístico, científico y literario de México desde la antigüedad más remota hasta la época actual / obra única en su género publ. bajo la dir. del Gral. Vicente Riva Palacio e imparcial y concienzudamente escrita en vista de cuanto existe de notable y en presencia de preciosos datos y documentos hasta hace poco desconocidos por los reputados literatos Alfredo Chavero, Vicente Riva Palacio, Julio Zárate, Juan de Dios Arias, Enrique de Olvarría. México, Cumbre, 1953

ROMERO DE TERREROS, Manuel. Una casa del siglo XVIII en México. La del Conde de San Bartolomé de Jala. Estudios y Fuentes de Arte en México, Vol. VIII. México, UNAM- IIE, 1957

ROS, Antonio. El tabaco, el café y el vino. México, Oasis, 1899

ROS Torres, María Amparo. La producción cigarrera a finales de la Colonia: La fábrica de México. México, Instituto Nacional de Antropología e Historia, Dirección de Estudios Históricos, 1984

SAHAGÚN, Bernardino de fray. Historia general de las cosas de la Nueva España: primera versión íntegra del texto castellano del manuscrito conocido como Códice Florentino / Bernardino de Sahagún1499-1590; introd., paleografía, glosario y notas de Alfredo López Austin y Josefina García Quintana. Madrid, ed. Alianza: Sociedad Quinto Centenario, v; 20 cm. ISBN 842062960X (ed. completa)

SARTORIUS, Christian. México y los Mexicanos, con 18 il. Por M. Rugendas; vers. Selección y notas de Marita Martínez del Río de Redo. México, San Ángel Ediciones, 1995

SOCIEDAD ESTATAL QUINTO CENTENARIO. Crónica Mixteca. El Rey 8 Venado, Garra de jaguar y la dinastía Teozacualco-Zachila. Libro explicativo del Ilamado Códice Nuttall. Madrid y México, FCE, 1992

RIVERA Cambas, Manuel. México Pintoresco Artístico y Monumental, Vistas, descripción, anécdotas y episodios de los lugares más notables de la capital y de los estados, aún de las poblaciones cortas, pero de importancia geográfica ó histórica. México, Imprenta de la Reforma, Perpetua 71/2, (Litográfica de Murguía) 1882

RODRIGUEZ Prampolini, Ida. La Crítica del Arte en México en el Siglo XIX. México, UNAM- IIE, 1997

SARRO, Enrique. La industria del tabaco en México: apuntes para una monografía. México, 1933

SALVAT. Diccionario Enciclopédico. Tabaco Historia. Tomo XI. Caracas, Orinoco, 1955 
SENEFELDER, Alois. A Complete Course of Lithography, Londres, Akerman, 101 Strand, 1819.

SOLIS, Felipe. Gloria y Fama Mexica. México, Museo Franz Mayer, Smurfil Cartón y Papel, Galería Abril, 1991

TENORIO Trillo, Mauricio. Artilugio de la nación moderna, México en las exposiciones universales 18801930. México, FCE, 1998.

TOUSSAINT, Manuel. La litografía en México en el Siglo XIX. México, UNAM, 1934

TOVAR, María Elena. La estructura político social de México en el Siglo XIX. Chiapas, Instituto Chiapaneco de Cultura, 1993

TRABULSE, Elías. Arte y Ciencia en la Historia de México. México, Fomento Cultural BANAMEX, 1995

TRABULSE Elías. Historia de la Ciencia en México (Obra completa). México, CONACyT- FCE, 1992

TRABULSE Elías. Historia de la Ciencia en México (Visión abreviada). México, FCE, 1997

TRABULSE, Elías; Guadalupe Jiménez C, et. al. Viajeros europeos del siglo XIX en México. México, Banamex, 1996

VIERA, Juan de. Compendiosa narración de la ciudad de México1719?- . México, Ed. Guarania, 1952.

VALLE Arizpe, Artemio. Calle vieja y calle nueva. México, Diana, 1977

VALLE Arizpe, Artemio. Historia de la ciudad de México según los retratos de sus cronistas. México, Ed. Pedro Robredo, 1939

VARGAS Lugo de Bosch, Elisa; Elena Horz de Vía, et. al. Bosquejos de México, Colección de grabados y litografías, México, Banco de México, 1987

VAZQUEZ, Josefina. Nacionalismo y educación en México. México, El Colegio de México, 1975

VICARY, Richard. Manual de litografía. Madrid, Blume, 1986

VILLEGAS, Abelardo. Positivismo y Porfirismo. México, SEP Setentas, 1972

WALDECK, Federico Maximiliano, Conde de. Voyage pittoresque et Archeologique dans la province de Yucatan pendant les annés 1834 et 1836. París, B. Dufour, 1837

WEBER, Wilhelm. A History of Lithography. London, Thames and Hudson, 1966

WORK, Thomas. Litografía para artistas. Barcelona, Leda, 1987

ZEA, Leopoldo. El positivismo en México. México, Studium-3, 1953 


\section{Libro - Traducción}

SELER, Eduard. Tr. Frenk Alatorre Margaret. Comentarios al Códice Borgia. México, Fondo de Cultura Económica,1963. Facsimilar del Códice Borgia.

SELER, Eduard y Augustus Henry Keane. Codex Fejérváry-Mayer: An Old Mexican Picture Manuscript in the Liverpool Free Public Museum 12014/M. Londres, Constable, 1901

\section{Artículo revista}

CASANOVA, Rosa y Eloísa Uribe. "Maximiliano y el liberalismo a pesar de los conservadores, 18601867" en: Historia del Arte Mexicano, Tomo 10, Arte del Siglo XIX, México, SEP-Salvat, 1982 Pp14611489.

GARCÍA Sanz, María Concepción. "Pinturas costumbristas del mexicano Miguel Cabrera, en: Revista Goya, №142 pp 186-193 México, 1972

MORETT Sánchez, Jesús Carlos. "La agricultura del contrato en México colonial" en: Revista de Geografía Agrícola. Análisis regional de la agricultura, No 11-12. México, julio 1986.

RAMIREZ, Fausto "La visión europea de la América Tropical. Los artistas viajeros" en: El Arte del Siglo XIX, México, Salvat, 1982

RIGUZZI, Paolo "México próspero: las dimensiones de la imagen nacional en el porfiriato" en: Historias No 20, México, INAH, 1984

Ruiz Meza, Víctor. Apuntes para la historia de la litografía en Toluca en el siglo XIX. México, junta Mexicana de Investigaciones Históricas, 1948.

TORRE Lloreda, Manuel de la. Diario de México Diciembre 26, 1806. En Historia y Cultura del Tabaco en México, 1806

VIDALES Giovannetti, María Dolores. "Una historia de la etiqueta". En: Estudios Históricos. Arquitectura y Diseño. 2003. No 8 México, UAM.

Filme

MAYAGOITIA Penagos, Laura y Claudio Romo. Proceso de recuperación de imágenes de piedras litográficas del acervo de la ENAP Plantel San Carlos, Video.. 2002

\section{Páginas web}

http://www.galeon.com/cigarros/curiosidades.htm Enrique Curet y Fuentes: Florencio Giménez. Club de Fumadores por la Tolerancia.

http://www.ambasadakube.org.rs/serbian/img/habanos/habanos1.jpg Litografía de caja de puros http://portaltaurino.com/matadores/el_gordito.htm 
http://www.galeon.com/anilo/toreo/Lagartijo.htm\#Lagartijo

http://www.jornada.unam.mx/2002/02/03/sem-gamboa.html La Jornada Semanal, 3 de febrero del 2002 Núm. 361

http://en.wikipedia.org/wiki/Silicon_carbide

www.agn.gob.mx RAMO: TABACO "Algunas importantes constancias del proceso seguido contra Mateo Rodríguez ante el Juez $3^{\circ}$ Correccional de la ciudad de México con motivo de la falsificación de varias marcas de cigarros y puros de los que son propietarios los Sres. A. Munuzuri y Cia".

http://www.decuencasantiago.org/hospitalsantiago/hs_botica.htm

\section{Tesis}

Mayagoitia Penagos, Laura. México en Miniaturas. El Atlas Pintoresco e Histórico de los Estados Unidos Mexicanos de García Cubas. Tesis de Maestría en Historia del Arte. México, UNAM. 2002 Instituto Nacional del Derecho de Autor. Registro Público de Derecho de Autor 03-2001-082910251700-01

\section{Discursos, conferencias, mecanogramas}

Céspedes del Castillo, Guillermo. "El tabaco en Nueva España". Discurso leído el día 10 de mayo de 1992 en acto de recepción pública por Guillermo Céspedes del Castillo y contestación por Gonzalo Anes y Abarres Castrillón. Madrid, Real Academia de Historia, 1992 


\section{INDICE DE ILUSTRACIONES}

\begin{tabular}{|c|c|c|}
\hline Figura & Nombre & Pág. \\
\hline \multicolumn{3}{|c|}{ INTRODUCCION } \\
\hline 1 & $\begin{array}{l}\text { Gil Blas de Santillana. ENAP Colección de piedras litográficas Imp } \\
\text { Laura Mayagoitia. } 2002\end{array}$ & III \\
\hline 2 & $\begin{array}{l}\text { Etiqueta de cigarros “La Victoria” ENAP Colección de piedras litográficas } \\
\text { Imp Laura Mayagoitia. } 2002\end{array}$ & III \\
\hline 3,4 y 5 & $\begin{array}{l}\text { Expediente 35de Registro de Autor. Para las marcas de cigarros "El } \\
\text { Gallo" y "El Gallito". Año1884 (Fotografía L. Mayagoitia 2003) }\end{array}$ & IV \\
\hline 6 & "Remedios prodigiosos". Litografía de Urrutia & $\mathrm{XIX}$ \\
\hline 7 & Etiqueta de cigarros "Centenarios" & $\mathrm{XX}$ \\
\hline \multicolumn{3}{|c|}{ CAPITULO 1} \\
\hline 8 y 9 & $\begin{array}{l}\text { Lavado de piedras. Becarios de la Maestría en Artes Plásticas. } \\
\text { Estacionamiento de la Academia de San Carlos. México. }\end{array}$ & 2 \\
\hline 10 & Piedra litográfica. "Cerveza Superior" Academia de San Carlos & 3 \\
\hline 11 & Piedra litográfica. "El Fénix" Academia de San Carlos & 3 \\
\hline 12 y 13 & $\begin{array}{l}\text { Alumnos becarios del posgrado en Artes Visuales Taller litográfico Calle } \\
\text { Academia } 22 .\end{array}$ & 4 \\
\hline 14 y 15 & $\begin{array}{l}\text { Imágenes del taller de conservación de piedras litográficas 2002. Calle } \\
\text { Academia No } 22 \text { (estacionamiento) }\end{array}$ & 4 \\
\hline 16 & Piedra Litográfica. Academia de San Carlos. ENAP & 5 \\
\hline 17 y 18 & $\begin{array}{l}\text { Cigarros "Triunfos" Tabacalera Michoacana. S.A. La Piedad Michoacán. } \\
\text { Papel arroz. Precio de fábrica } 5 \text { centavos cajetilla. Marca Ind. } \\
\text { Registrada } 8 \text { de mayo de } 1925 \text {. Impr. L. Mayagoitia. Academia de San } \\
\text { Carlos. 2003. Impresión en papel guarro (separación de color) Impr. L. } \\
\text { Mayagoitia, 2003. }\end{array}$ & $6-7$ \\
\hline 19 & $\begin{array}{l}\text { Ponciano Almada y Ca. Sucs. Zazueta y Ca. Culiacán, Registro No 1, } \\
\text { Calle del Comercio no 10, Marca "La Abundancia", Imp. L. Mayagoitia } \\
\text { 2003.Litografía etiqueta de cigarros Zazueta y Ca }\end{array}$ & 7 \\
\hline 20 & $\begin{array}{l}\text { Etiqueta de la Fábrica de tabacos y cigarros. Selección de color. Imp. L. } \\
\text { Mayagoitia } 2003\end{array}$ & 8 \\
\hline 21 у 22 & $\begin{array}{l}\text { Laura Mayagoitia en el Acervo Lino Picaseño. Facultad de Arquitectura. } \\
\text { UNAM. 2007. Fotografía. L. Mayagoitia }\end{array}$ & 9 \\
\hline 23 y 24 & $\begin{array}{l}\text { Expediente de registro de propiedad artística. Penichet y Cía. } 1 \text { de Julio } \\
\text { de 1902. Acervo Academia de San Carlos. Biblioteca Lino Picaseño. } \\
\text { Etiqueta Marca "El Pabellón Mexicano" }\end{array}$ & 10 \\
\hline 25 & The Guglier lito Cํㅡㄹ Cromolitografía & 11 \\
\hline 26 & Cía Litográfica Gossefin. Empaque para cigarros “Centenarios" & 12 \\
\hline$s / n$ & Etiquetas del Acervo Lino Picaseño. & 13 \\
\hline
\end{tabular}




\section{CAPITULO 2}

\begin{tabular}{|c|c|c|}
\hline 27 & $\begin{array}{l}\text { Códice Borgia, lámina 10, pintura 18. Las cinco regiones del mundo y } \\
\text { sus deidades. Cintéotl Dios del maíz. Cihuatlampa. El Oeste }\end{array}$ & 25 \\
\hline 28 & Fig. 2 Casa del Oeste, Casa de los Mantenimientos (Detalle) & 25 \\
\hline 29 & $\begin{array}{l}\text { Fig.. } 3 \text { El yetecómatl. Casa del Oeste, Casa de los Mantenimientos } \\
\text { (Detalle) }\end{array}$ & 26 \\
\hline 30 & Día 18 Chalchihuitl. “Joya de agua” & 27 \\
\hline 31 & Iztac Mixcóat/ Códice Borgia Lámina 24 & 28 \\
\hline 32 & $\begin{array}{l}\text { Las veinticinco parejas divinas. Ilancueye La vieja diosa de la tierra } \\
\text { Iztac Mixcoat/ Viejo Dios del Cielo }\end{array}$ & 29 \\
\hline 33 & Día 12 de la región de abajo & 31 \\
\hline 34 & Tonalámatl Libro de los días & 32 \\
\hline 35 & Tonalámatl (detalle de la lámina 1, Codice Borgia) & 34 \\
\hline 36 & Tlamacazqui & 34 \\
\hline 37 & Ome Izuintli Manuscrito de Vienna 10 & 34 \\
\hline 38,39 y 40 & El Anciano Sacerdote Ome Itzcuintli, 2 Perro & 35 \\
\hline 41 & Representación del bule de tabaco & 38 \\
\hline 42 & Representación del polvo de tabaco & 38 \\
\hline 43 & Representación del humo del tabaco & 38 \\
\hline 44 & $\begin{array}{l}\text { Lámina 2, pintura } 8 \text { del Códice Nutall El Señor } 7 \text { Viento, el Hombre } \\
\text { verde que esparció tabaco. }\end{array}$ & 40 \\
\hline 45 & $\begin{array}{l}\text { Lámina 2, pintura } 9 \text { del Códice Nutall El Señor } 10 \text { Jaguar Cargador del } \\
\text { Bule de tabaco }\end{array}$ & 40 \\
\hline 46 & $\begin{array}{l}\text { Lámina } 4 \text { pintura } 19 \text { El cargador del precioso bule de tabaco El Señor } 2 \\
\text { Perro. }\end{array}$ & 41 \\
\hline 47 & $\begin{array}{l}\text { El señor } 6 \text { Muerte, Pájaro Jaguar ofrece una codorniz y polvo de } \\
\text { tabaco }\end{array}$ & 41 \\
\hline 48 & $\begin{array}{l}\text { Lámina } 7 \text { pintura 3. El Señor } 5 \text { Movimiento, Águila Roja de Tabaco } \\
\text { Ardiente. }\end{array}$ & 42 \\
\hline 49 & $\begin{array}{l}\text { Lámina } 9 \text { pintura } 5 \text {. Señor } 4 \text { Agua, Jaguar de Cuya boca sale Vapor, } \\
\text { tiene polvo de tabaco en la mano }\end{array}$ & 43 \\
\hline 50 & $\begin{array}{l}\text { Lámina } 9 \text { pinturas } 17 \text { y } 18 \text { Señor } 3 \text { Caña y Señor } 4 \text { jaguar quien } \\
\text { quemaba tabaco en un incensario en forma de animal. }\end{array}$ & 43 \\
\hline 51 y 52 & $\begin{array}{l}\text { Lámina } 11 \text { pinturas } 14 \text { Señor } 7 \text { Caña, Antorcha de Tabaco Ardiente y } \\
\text { Señor } 3 \text { Flor, Príncipe dedicado al fuego le ofrece tabaco }\end{array}$ & 45 \\
\hline 53 & $\begin{array}{l}\text { Fig. Lámina } 14 \text { Dos ancianos cargadores de bules de tabaco: Pintura 8: } \\
\text { El Señor } 10 \text { Lluvia "Jaguar que respira fuego" y Figura 9: el Señor } 10 \\
\text { Hierba "Jaguar que respira fuego". }\end{array}$ & 45 \\
\hline 54 & $\begin{array}{l}\text { Lámina } 5 \text { figuras } 5 \text { y } 6 \text { ancianos cargadores de los bules de tabaco el } \\
\text { Señor } 10 \text { Lluvia y el Señor } 10 \text { Hierba }\end{array}$ & 45 \\
\hline 55 & Lámina 16 pintura 12 Anciano Cargador del Bule de Tabaco Señor 10 & 46 \\
\hline
\end{tabular}




\begin{tabular}{|c|c|c|}
\hline & Hierba & \\
\hline 56 & Lámina 17 pintura 7. El Señor 9 Flor & 47 \\
\hline 57 & Lámina 17 pintura 1 Señor 2 Perro Cargador del Bule de Tabaco. & 48 \\
\hline 58 & $\begin{array}{l}\text { Lámina } 19 \text { a El Señor } 9 \text { Movimiento Antorcha de Tabaco Ardiente como } \\
\text { el Cargador de Caracol. }\end{array}$ & 48 \\
\hline 59 & Lámina 19a pinturas 13 y 14 Ancianos cargadores del bule de tabaco & 49 \\
\hline 60 & $\begin{array}{l}\text { Lámina 19b pintura 27. Anciano Cargador del bule de tabaco Señor } 7 \\
\text { Flor }\end{array}$ & 49 \\
\hline 61 & Lámina 19 b pintura 42.EI Señor 10 Lluvia Jaguar. & 50 \\
\hline 62 & $\begin{array}{l}\text { Lámina } 21 \text { pintura } 1 \text {. Anciano cargador del bule de tabaco. En la } \\
\text { ceremonia de decapitación }\end{array}$ & 51 \\
\hline 63 & $\begin{array}{l}\text { Lámina } 25 \text { pinturas } 11,12 \text { y } 13 \text { el Señor } 5 \text { Lagarto recibe a los } \\
\text { sacerdotes quienes le rinden homenaje con tabaco. }\end{array}$ & 52 \\
\hline 64 & Lámina Señor Nueve Flor Antorcha de Tabaco Ardiente & 53 \\
\hline 65 & Lámina 27 pintura 8. Señora 2 Hierba Joya de Tabaco Ardiente & 53 \\
\hline 66 & Lámina 43 pintura 2 Señor 9 Flor Flecha de Tabaco Ardiente. & 54 \\
\hline 67 & $\begin{array}{l}\text { Lámina } 82 \text { pintura 1,2,3 Grafica del asesinato de } 12 \text { Movimiento en el } \\
\text { temazcal }\end{array}$ & 55 \\
\hline 68 & $\begin{array}{l}\text { Lámina } 82 \text { pinturas } 9,10,11 \text { Los sacerdotes colocan el cráneo y } \\
\text { huesos de } 12 \text { Venado sobre un rosetón lo adornaron y ofrecieron } \\
\text { codornices y tabaco hicieron humear el rosetón con el fuego de la } \\
\text { antorcha }\end{array}$ & 55 \\
\hline 69 & Toponímicos: Cerro Gordo, Loma de la Flecha y Ciudad del Jaguar. & 56 \\
\hline 70 & Lámina 81 & 57 \\
\hline 71 & Etiqueta. “Los Mexicanos" Olavarrieta Calle de la Merced No. 31 & 63 \\
\hline 72 & Grabado de planta de Tabaco. Nicolas Monrades & 65 \\
\hline 73 & $\begin{array}{l}\text { Anónimo. "Dama con caja de rapé". Mediados del siglo XVIII. Óleo } \\
\text { sobre tela } 83 \times 63 \mathrm{~cm} \text { (oval) Col. Museo Nacional de Historia. }\end{array}$ & 68 \\
\hline 74 & $\begin{array}{l}\text { Fábrica de cigarros, por Manuel Conique, Guadalajara, 1779. AGN } \\
\text { Tabaco, vol. 506, exp. 201, f. 26, (4928) (detalle). }\end{array}$ & 70 \\
\hline 75 & $\begin{array}{l}\text { Piedra litográfica. Academia de San Carlos de México. Marca: "El } \\
\text { Pabellón Mexicano". A Barragán Etiqueta para caja de puros. }\end{array}$ & 76 \\
\hline 76 & $\begin{array}{l}\text { Academia de San Carlos de México. Marca: "El Pabellón Mexicano". A } \\
\text { Barragán Etiqueta para caja de puros. Imp. L. Mayagoitia. } 2003 \\
\text { Imprimió L. Mayagoitia. Academia de San Carlos de México. }\end{array}$ & 76 \\
\hline 77 & Marca: “El profeta”. Fábrica de Cigarros de T. Olavarrieta, 1885 & 78 \\
\hline 78 & $\begin{array}{l}\text { Marca: El Artesano.Fábrica de Mercado Hermano Abril 14, } 1886 \\
\text { Baranda11062 Lit. Debray y Sucs. }\end{array}$ & 79 \\
\hline 79 & $\begin{array}{l}\text { Fábrica de Delgado y Naverán. Reg. Propiedad a favor de Gregorio } \\
\text { Palacio y Cía Marca: "El Rey del Mundo" }\end{array}$ & 79 \\
\hline 80 & $\begin{array}{l}\text { "La lotería" Registro de propiedad artística de Tomás Mercado. } 19 \text { Nov, } \\
1886 \text { Marca "La Lotería". }\end{array}$ & 80 \\
\hline 81 & "La melodía" Litografía para las cajas de puros de Balsa Hermanos & 83 \\
\hline
\end{tabular}




\begin{tabular}{|c|c|c|}
\hline 82 & La Estanquillera. En: Los mexicanos pintados por sí mismos. Litografía & 85 \\
\hline 83 & Etiqueta de cigarros. E. Pugibet. 1805. Litografía & 86 \\
\hline 84 & Trabajadoras del Buen Tono. Fotografía & 87 \\
\hline 85 & Ernesto Pugibet, acompañado por marinos japoneses. & 89 \\
\hline 86 & $\begin{array}{l}\text { Etiqueta. Fábrica de La Bola P. Munguía e Hijos. Papel de hoja de } \\
\text { maíz. Cda. de la Merced No } 3 \text { México. }\end{array}$ & 90 \\
\hline 87 & $\begin{array}{l}\text { Etiqueta. Fábrica de puros y cigarros "La Bola Sin Rival". Calle de la } \\
\text { Merced No } 3 \text { Etiqueta }\end{array}$ & 91 \\
\hline $88-89$ & $\begin{array}{l}\text { Etiquetas. Marca "La Reina". Fábrica de cigarros finos para señoras de } \\
\text { P. Munguía e Hijos }\end{array}$ & 92 \\
\hline 90 & Vegas de la propiedad de la Fábrica El Borrego. México. & 93 \\
\hline 91 & "Los aztecas". Tamaño Águilas. Donato González. Acequia 20 México & 94 \\
\hline 92 & AGN Fondo Teixidor. Trabajadoras del Buen Tono & 95 \\
\hline 93 & $\begin{array}{l}\text { "La ideal" manufactura de tabacos de Julio Pugibet y Cía. Cigarros } \\
\text { perfeccionados al estilo francés }\end{array}$ & 96 \\
\hline \multicolumn{3}{|c|}{ CAPITULO 3} \\
\hline 94 & Johann Moritz Rugendas. "Placeros y rancheros" & 100 \\
\hline 95 & Prida y Cía Veracruz Litográfica de Moreau y Hnos. México I-3 & 101 \\
\hline 96 & Eduard Pingret "El aguador". & 102 \\
\hline 97 & Linati. “El lépero”. & 103 \\
\hline 98 & Linati "El carnicero" & 103 \\
\hline 99 & Linati. "El negro acostado en su hamaca" & 104 \\
\hline 100 & Álbum Pintoresco de la República Mexicana 1849 - 1852 & 105 \\
\hline 101 & "El Tabaco". En: El Álbum Mexicano & 106 \\
\hline 102 & "El cajista" & 108 \\
\hline 103 & "La china". Los mexicanos pintados por si mismos & 108 \\
\hline 104 & $\begin{array}{l}\text { No tengo ganas de pasear señora, comadre o demonio!-¡Mire que soy } \\
\text { una doncella!- ¡Nadie lo diría! }\end{array}$ & 109 \\
\hline 105 & Campillo, Trajes mexicanos. & 110 \\
\hline 106 & Detalle & 110 \\
\hline 107 & El Jarabe. Dib y Lit” ${ }^{\mathrm{a}}$ Campillo. En: México y sus Alrededores & 111 \\
\hline 108 & Detalle & 111 \\
\hline 109 & Lekythoi & 113 \\
\hline 110 & Canopes & 114 \\
\hline 111 & Frascos de Botica & 116 \\
\hline 112 & Botica & 117 \\
\hline $113,114.115$ & Etiquetas Registro de autor: Donato Guerra. Acervo Lino Picaseño & 119 \\
\hline 116 & $\begin{array}{l}\text { "El Gallito" Fábrica de cerillos No } 1 \text { Teodoro Campos y Ca. } 2 \text { da de Sto. } \\
\text { Domingo No } 10 \text { México. Único depósito. Tabaquería del Gallito T. } \\
\text { Campos y Cía. }\end{array}$ & 120 \\
\hline 117 y 118 & Etiqueta Julián Álvarez y etiqueta Álvarez e Hijo & 122 \\
\hline
\end{tabular}




\begin{tabular}{|c|c|c|}
\hline 119,120 & $\begin{array}{l}\text { Etiquetas: "La Selecta" de Álvarez e Hijo y "La Selecta" cromolitografía } \\
\text { de la fábrica Álvarez e Hijo }\end{array}$ & 123 \\
\hline 121 & Etiqueta. Marca: "Primera Diana" de Julián Álvarez & 123 \\
\hline 122 & Etiqueta. Marca: “La Flor” de Henry Clay Habana & 123 \\
\hline 123 & $\begin{array}{l}\text { Etiqueta. Marca: "Henry Clay". Fábrica de Tabacos de Habana. Clz. } \\
\text { Luyano No } 100 \text { Depósito Calle Oradly No } 9 \text { 1⁄2 Julián Álvarez }\end{array}$ & 123 \\
\hline 124 & $\begin{array}{l}\text { Marca: "Henry Clay". Fábrica de Tabacos de Habana. Clz. Luyano No } \\
100 \text { Depósito Calle Oradly No } 9 \text { 1⁄2 Julián Álvarez }\end{array}$ & 124 \\
\hline 125 y 126 & Etiqueta Marca: "Primera Diana”, Fábrica de Julián Álvarez & 124 \\
\hline 127 & "Primera Diana". Fábrica de Julián Álvarez & 124 \\
\hline 128 & $\begin{array}{l}\text { "Don Julián Álvarez” Habana. Chavalier de L’Ordre Nationale de la } \\
\text { Legion D’Honneur Exposition } 1878\end{array}$ & 125 \\
\hline 129 & Etiqueta para caja de puros. Marca: “La Corola” Fábrica Prida y Ca. & 126 \\
\hline 130 & Etiqueta para caja de puros. Isla de Cuba. Habanos & 126 \\
\hline $\begin{array}{l}131,132 \quad y \\
133\end{array}$ & Ejemplos de habilitaciones de la fábrica La Bola & 126 \\
\hline 134 & Habilitación de la fábrica de J. Esteva y Cía & 127 \\
\hline 135 & Habilitación de la fábrica "La Bola Sin Rival" & 127 \\
\hline 136 & Papeleta de la marca: "Supremos" de la Fábrica de Remigio Noriega & 128 \\
\hline 137 & Vitola "Cuauhtemoc" & 128 \\
\hline 138 & Vitola Regalía "La Rica Hoja" & 129 \\
\hline $\begin{array}{l}139, \quad 140 \\
141 \text { y } 142\end{array}$ & Etiqueta de la marca "El Destino" de la fábrica de Manuel P. García & 130 \\
\hline 143 & Vitola "Águila de Oro" & 131 \\
\hline 144 & Vitola. "Porfirio Díaz" H. Upmann & 132 \\
\hline 145 & Vitola "Glorias de Porfirio Díaz" A. Blanco & 132 \\
\hline 146 & Vitola "Especiales para el Coronel González" Partagas & 133 \\
\hline 147 & $\begin{array}{l}\text { Vitola "Recuerdos del Centenario" Independencia, Reforma, Paz A.P \& } \\
\text { Co }\end{array}$ & 134 \\
\hline 148 & Vitolas de la Fábrica de puros La Violeta, Orizaba, 1910. & 135 \\
\hline 149 & Etiqueta de cigarros marca "La Vencedora". & 135 \\
\hline 150 & Vitola "Toro de Lidia" L. Grobet y C & 136 \\
\hline 151 & Etiqueta de la marca "El Gordito" Fábrica de Ignacio Álvarez & 137 \\
\hline 152 y 153 & Etiquetas de la marca "El Torero" & $137-138$ \\
\hline 154 & Etiqueta de la marca "El Lagartijo" Fábrica de Ibarguen y Abasolo & 139 \\
\hline 155 & "La ilusión" Eusebio Rojas & 140 \\
\hline
\end{tabular}




\begin{tabular}{|c|c|c|}
\hline 156 & "Las dos naciones" Fábrica de González Hnos. & 140 \\
\hline 157 & Vitola "Glorias de Benito Juárez" A. Blanco & 141 \\
\hline 158 & Marca "La Asturiana" Remigio Noriega & 142 \\
\hline 159 & $\begin{array}{l}\text { Fábrica de la Fama Tabaco superior de Compostela. Eusebio } \\
\text { Castellanos a cargo de la viuda e hijos "Porfirio Díaz" }\end{array}$ & 143 \\
\hline 160 & $\begin{array}{l}\text { Doble marca "Sol de Mayo" de C. Uribe. Fábrica de puros y Cigarros } \\
\text { por C. Uribe. Despacho de fábrica Esquina Urbina y la Merced, } \\
\text { Toluca. Premiada en la exposición del Estado de México, con medalla } \\
\text { de plata }\end{array}$ & 143 \\
\hline 161 & "El Destino". Litografía para caja de puros & 144 \\
\hline 162 & $\begin{array}{l}\text { "La Patria" ¿Quién vive? México, Siempre contra todo. Marca } \\
\text { depositada. Julio Pugibet y Ca. Manufactura de tabacos de Julio } \\
\text { Pugibet y Cía. México. Cigarros Extra al estilo habano. Cigarettes } \\
\text { genre francais perfeccionnées Cigarette perfezionate all estilo } \\
\text { francese }\end{array}$ & 145 \\
\hline 163 & $\begin{array}{l}\text { "La Mascota" Cigarros exquisitos con tabaco en hebra ¡No hay } \\
\text { mejores! Ernesto Pugibet y Cía. Sn Felipe Neri No } 12 \text { México El libro } \\
\text { de las mascotas Cap. III }\end{array}$ & 145 \\
\hline 164 & Logogrifo de Urrutia de época anterior a las historietas. & 147 \\
\hline 165 & "La ilusión" Especiales. Jeroglífico $\mathrm{N}^{\circ} 5$ & 147 \\
\hline 166 & “Adelina Patti”. Plaza Principal. Arido Rosales. Jeroglífico No 47 & 147 \\
\hline 167 & $\begin{array}{l}\text { "Genoveva de Bramante". Historieta copiada por Urrutia de alguna } \\
\text { estampa de Espinal }\end{array}$ & 148 \\
\hline 168 & $\begin{array}{l}\text { "Genoveva de Bramante". Historieta copiada por Urrutia de alguna } \\
\text { estampa de Espinal (izquierda). Historietas impresas de una piedra de } \\
\text { la ENAP Academia de San Carlos (derecha) }\end{array}$ & 149 \\
\hline 169 & $\begin{array}{l}\text { Gil Blas de Santillana, ENAP Colección de piedras litográficas, Imp } \\
\text { Laura Mayagoitia }\end{array}$ & 149 \\
\hline 170 & Litografía "El remedio del siglo XX" Jeroglífico de Urrutia & 150 \\
\hline 171 & Lit $^{\circ}$ Trinidad Pedroza."El valor mejicano" & 151 \\
\hline 172 & José Guadalupe Posada. Litografías para cajetillas de cigarros & 152 \\
\hline 173 & $\begin{array}{l}\text { José Guadalupe Posada. Grabado y plancha. Museo J. G. Posada. } \\
\text { Aguascalientes }\end{array}$ & 153 \\
\hline 174 y 175 & $\begin{array}{l}\text { Casimiro Castro. Acuarela para etiqueta de cigarros "El Borrego" y } \\
\text { "Asturiana" y etiquetas de cigarros "La Asturiana" }\end{array}$ & 154 \\
\hline 176 & "El peso fuerte". Etiquetas de cigarros de González Hnos. & 155 \\
\hline 177 & "El peso fuerte" Etiquetas de cigarros de González Hnos. & 155 \\
\hline 178 & Etiqueta de cigarros "Especiales" de Yernoy Santa Cruz" & 155 \\
\hline 179 & Etiqueta para cigarros. Gabino Oseguera & 156 \\
\hline
\end{tabular}




\begin{tabular}{|c|c|c|}
\hline 180 у 181 & $\begin{array}{l}\text { Expediente de Registro Autoral. Abril de 1886. Marcas y etiquetas de } \\
\text { los puros del C. Amador Fletes de Tepic. Acervo Lino Picaseño. } \\
\text { UNAM }\end{array}$ & 159 \\
\hline 182 & $\begin{array}{l}\text { Etiquetas de puros de la marca Amador Fletes. Acervo Lino Picaseño. } \\
\text { Fotografía L. Mayagoitia }\end{array}$ & 160 \\
\hline 183 & $\begin{array}{l}\text { "El Destino" García Hermano y Cía. San Andrés Tuxtla. Fábrica de } \\
\text { Tabacos. }\end{array}$ & 161 \\
\hline \multicolumn{3}{|c|}{ CAPITULO 4} \\
\hline $\begin{array}{l}184,185 \quad y \\
186\end{array}$ & $\begin{array}{l}\text { Etiquetas de cigarros de las marcas "Los mexicanos", "Los Aztecas" y } \\
\text { "El destino" de las fábricas de Olavarrieta, Donato González y García } \\
\text { Hno. Respectivamente }\end{array}$ & 163 \\
\hline 187 & $\begin{array}{l}\text { Tabacos supremos- Gran fábrica de puros y cigarros."Moctezuma". } \\
\text { Guanajuato. R. Zamorano y Comp. Calle de Belem } 28\end{array}$ & 163 \\
\hline 188 & $\begin{array}{l}\text { "Los patriotas de América” México, América del Norte, América del Sur. } \\
\text { Miguel Hidalgo, Jorge Washington, Simón Bolívar. Excelentes. Donato } \\
\text { González, Acequia } 20 \text { México }\end{array}$ & 164 \\
\hline 189 & $\begin{array}{l}\text { Fernández y Bermejillo. "El Caudillo Mexicano" M. Hidalgo y Costilla. } \\
\text { Gran fábrica de cigarros. Depósito } 1^{\underline{a}} \text { Calle de Sto. Domingo No. } 9 \\
\text { Tabaquería de la Paz. El mejor tabaco del mundo. Papel sin igual. }\end{array}$ & 165 \\
\hline 190 & $\begin{array}{l}\text { "El caudillo mexicano" Patria libertad y progreso. Gran Fábrica de puros } \\
\text { y cigarros especiales Barberena No 18. Villa y Hno. México (imágenes } \\
\text { de Juan Almonte y Miguel Hidalgo y Costilla) }\end{array}$ & 166 \\
\hline 191 & $\begin{array}{l}\text { "Porfirio" Propiedad Artística Remigio Noriega. Firma Baranda. Registro } \\
\text { de la Academia de San Carlos 11061. Marca depositada "La Asturiana". } \\
\text { Fábrica de cigarros y puros de picadura de hebra. Capuchinas } 12 \\
\text { México. Fábrica Calle de la Libertad No. } 2 \text { México }\end{array}$ & 167 \\
\hline 192 & $\begin{array}{l}\text { "Glorias de México" El } 5 \text { de Mayo Fábrica Los Aztecas de Donato } \\
\text { González }\end{array}$ & 169 \\
\hline 193-194 & $\begin{array}{l}\text { Etiquetas de la fábrica de puros y cigarros de Ruiz Oseguera. "El héroe } \\
\text { de la intervención y "El Héroe del } 2 \text { de Abril" }\end{array}$ & 169 \\
\hline 195 & Cigarros “Los Patriotas" Fábrica de José Benet y Hno. & 170 \\
\hline 196 & $\begin{array}{l}\text { "Porfirio Díaz" Para la elegancia mexicana. Se perseguirá ante la ley a } \\
\text { todo falsificador Fábrica de puros y cigarros Ruiz Oceguera y Comp.- }\end{array}$ & 171 \\
\hline 197 & $\begin{array}{l}\text { "La Batalla de Tecoac". Para la elegancia mexicana. Se perseguirá ante } \\
\text { la ley a todo falsificador- Fábrica de puros y cigarros Ruiz Oseguera y } \\
\text { Comp. Depósito J.M: Barragán Cocheras Núm. } 2 \text { México. Marca } \\
\text { depositada. Especiales "La Batalla de Tecoac" }\end{array}$ & 172 \\
\hline 198 & $\begin{array}{l}\text { Fuente de las Circasianas. Hacienda de Chapingo, México, Texcoco, } \\
\text { Edo. de México. Fotografía L. Mayagoitia febrero } 2008\end{array}$ & 175 \\
\hline 199 & $\begin{array}{l}\text { Registro de propiedad artística Gregorio Palacios y Cía, fecha: } 7 \\
\text { noviembre 1884. Firma Baranda, Registro de la Guía de la Academia de } \\
\text { San Carlos } 11010 \text {. Marca "La Circasiana". Litográfica La Española. } \\
\text { Gran Fábrica de cigarros con tabacos de San Andrés Tuxtla. Picadura }\end{array}$ & 176 \\
\hline
\end{tabular}




\begin{tabular}{|c|c|c|}
\hline & suprema. Juan Vega. El mejor tabaco Veracruz & \\
\hline 200 & $\begin{array}{l}\text { Fuente de las ciracianas y casa principal de la Hacienda de Chapingo, } \\
\text { hoy Universidad Autónoma de Chapingo. México, Texcoco, Edo de } \\
\text { México. Fotografía L. Mayagoitia } 2008\end{array}$ & 176 \\
\hline 201 & $\begin{array}{l}\text { "Romero Rubio". Marca depositada. Elegantes Los cigarros fabricados } \\
\text { al gusto de la capital no tienen comparación en la República. } \\
\text { Especiales. Fábrica Calle de la Libertad No } 2 \text { La Asturiana. Remigio } \\
\text { Noriega. México, Capuchinas } 12 \text {.Esta fábrica elabora la mostaza y } \\
\text { salsa nacional. }\end{array}$ & 177 \\
\hline 202 & $\begin{array}{l}\text { "General Porfirio Díaz" Fábrica de tabacos "La Fama", de Eusebio } \\
\text { Castellanos. Fecha de registro de propiedad artística a favor de la Sra. } \\
\text { Viuda de Castellanos, Nov.4, } 1885 \text { e hijos. Registro en la Guía de la } \\
\text { Academia de San Carlos } 11061 . \text { Tabaco superior de Compostela. } \\
\text { Tepic. }\end{array}$ & 178 \\
\hline 203 & $\begin{array}{l}\text { Gran Fábrica de Cigarros Fernández y Bermejillo. Fecha de registro de } \\
\text { propiedad artística } 22 \text { de mayo de } 1884 \text { a favor de Ruíz Oceguera. } \\
\text { Firma Baranda. Registro de la Guía de la Academia de San Carlos } \\
11010 . \text { Marca "El Ex presidente" El Mejor tabaco del mundo. Papel sin } \\
\text { igual. Depósito Calle Sto Domingo No } 9 \text { México. Tabaquería La paz. } \\
\text { Litográfica Moreau Hnos. }\end{array}$ & 179 \\
\hline 204 & $\begin{array}{l}\text { Fábrica de tabacos y registro de propiedad artística de Gregorio } \\
\text { Palacios y Cía. Fecha: } 27 \text { julio 1887. Marca "Very Good". Registro en la } \\
\text { Guía de la Academia de San Carlos 11065. Litográfica La Española. }\end{array}$ & 180 \\
\hline 205 & $\begin{array}{l}\text { Marca "La Conquista" Gran Fábrica de Tabacos Labrados. Registro de } \\
\text { propiedad Artística a favor de Gregorio Palacios y Cía. Fecha: } 7 \text { de } \\
\text { noviembre de 1884. Firma Baranda, Registro de la Academia de San } \\
\text { Carlos } 11010 \text {. Litográfica La Española. Gran fábrica de tabacos } \\
\text { labrados de gusto exquisito comodidad y limpieza sin rival en calidad. } \\
\text { Sacramento Chávez. Morelia Portal de Iturbide letra D }\end{array}$ & 181 \\
\hline 206 & Fábrica "La estrella" Juan Hegart. Cerillos Universales. Morelia & 181 \\
\hline 207 & "La liga de la honradez" Fábrica de C. Olivarría & 182 \\
\hline 208 & $\begin{array}{l}\text { Etiqueta de cigarros. Marca "La concordia". Depósito de cigarros y } \\
\text { cerillos de Jacinto Carmona. }\end{array}$ & 183 \\
\hline 209 & Etiqueta de cigarros. Marca “El madrigal” José María Merino & 183 \\
\hline 210 & $\begin{array}{l}\text { Etiqueta para puros marca "La Veracruzana" La imagen tomada de una } \\
\text { piedra de la Academia de San Carlos, con separación de color. La } \\
\text { imagen fue trabajada a partir de medios electrónicos Photoshop para } \\
\text { lograr integración de color e impresión de la etiqueta. L. Mayagoitia. } \\
\text { Academia de San Carlos } 2003 \text {. }\end{array}$ & 184 \\
\hline 211 & Tipos de piedra. Cuadro comparativo & 189 \\
\hline 212 & $\begin{array}{l}\text { Litografía Impresa. Marca de cigarros "La Victoria". Lito Dra. Laura } \\
\text { Mayagoitia, Academia de San Carlos, México } 2003 \text { (Con separación de } \\
\text { colores) }\end{array}$ & 194 \\
\hline
\end{tabular}




\begin{tabular}{|l|l|r|}
\hline 213 y 214 & $\begin{array}{l}\text { Litografía impreso por medios electrónicos. Marca de cigarros “La } \\
\text { Victoria". Detalle. }\end{array}$ & 194 \\
\hline 215 & Piedra litográfica. ENAP & 194 \\
\hline CAPITULO 5 & 197 \\
\hline 216 & Pantalla inicial del sistema & 198 \\
\hline 217 & Ficha de captura y visualización de registros & 198 \\
\hline 218 & Tabla general de información & 199 \\
\hline 219 & Tabla general de información & 200 \\
\hline 220 & Reportes & 201 \\
\hline 221 & Logotipo del Sistema Maya & \\
\hline ANEXO 1 & Colección de piedras litográficas. ENAP, Academia de San Carlos \\
\hline ANEXO 2 & CD Sistema MAYARATACIERRAELPICO & \\
\hline
\end{tabular}




\title{
ANEXO 1 COLECCIÓN DE PIEDRAS LITOGRÁFICAS.
}

\author{
UNAM - ENAP
}

ACADEMIA DE SAN CARLOS 


\begin{tabular}{|c|c|c|c|}
\hline $\begin{array}{l}\text { Numero } \\
\text { de piedra }\end{array}$ & DESCRIPCION & Dimensión & $\begin{array}{l}\text { Imagen y número de registro } \\
\text { fotográfico }\end{array}$ \\
\hline 1 & $\begin{array}{l}\text { Etiqueta tabacos "La conquistadora" } \\
\text { Condiciones piedra: Faltantes en ángulo } \\
\text { inferior izquierdo }\end{array}$ & $32 \times 27 \times 5 \mathrm{~cm}$ & $\left.\right|_{1}$ \\
\hline $1 b$ & $\begin{array}{l}\text { Etiqueta puros "El gallito" e } \\
\text { imágenes de caras }\end{array}$ & & 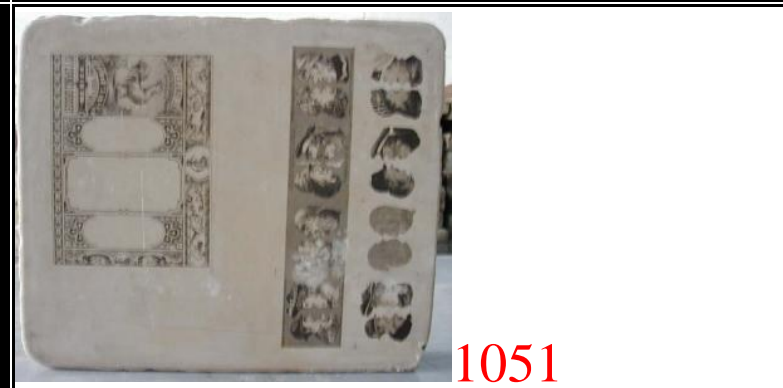 \\
\hline
\end{tabular}




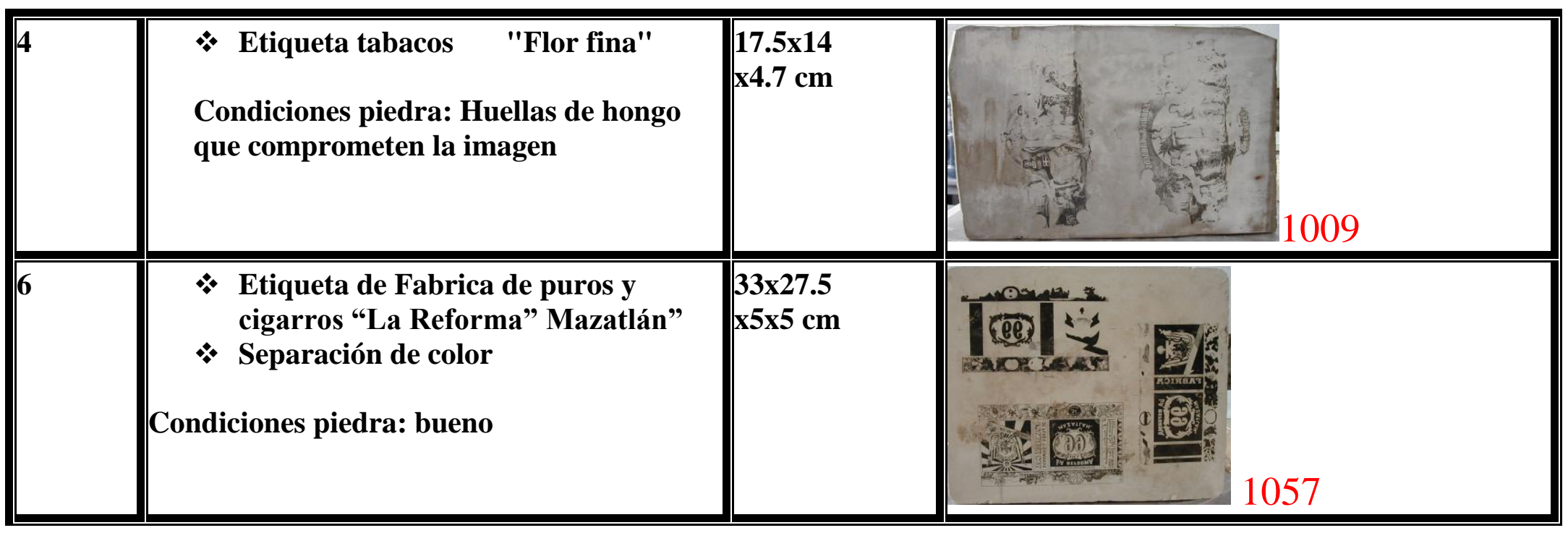




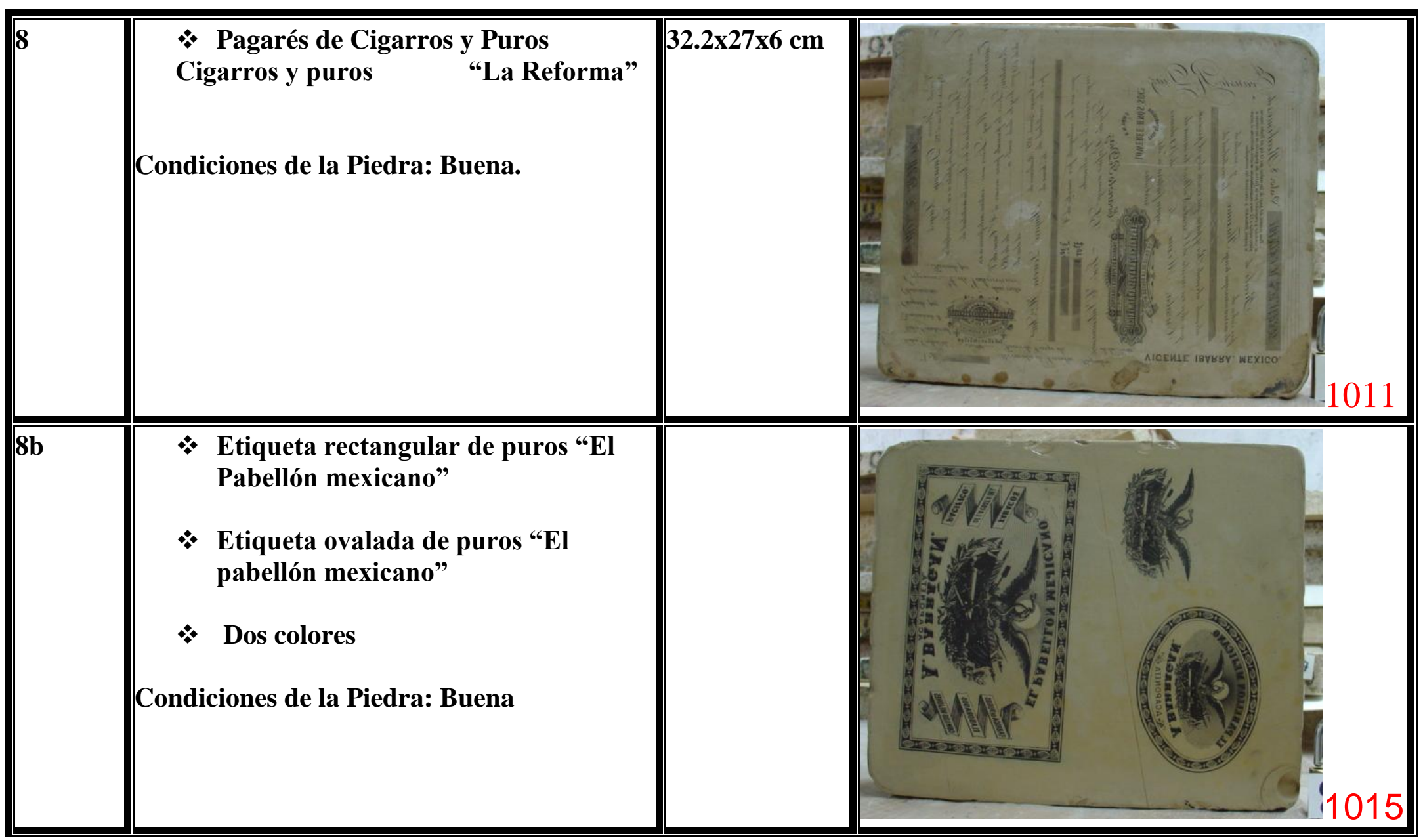




\begin{tabular}{|c|c|c|c|}
\hline 12 & $\begin{array}{l}\text { Etiqueta de Cigarros y tabacos "La } \\
\text { Abundancia" } \\
\text { Etiqueta de cerillos "La } \\
\text { Abundancia" }\end{array}$ & $30 \times 24.5 \times 4 \mathrm{~cm}$ & 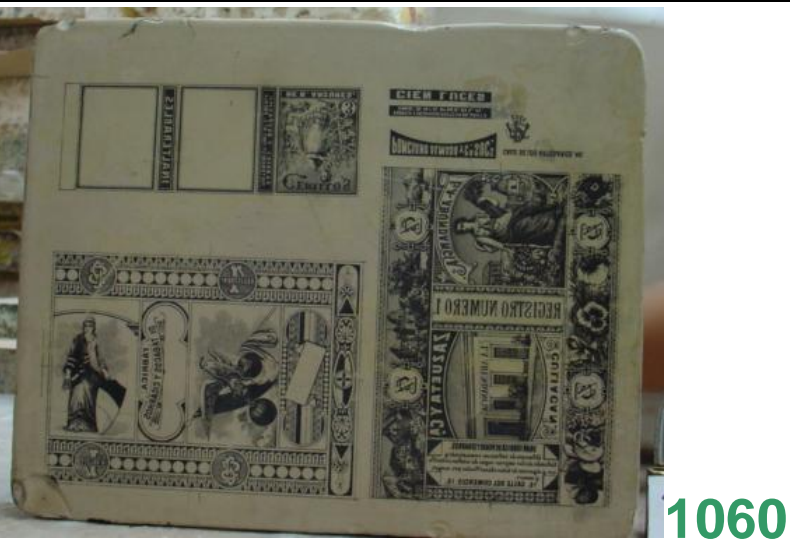 \\
\hline 17 & $\begin{array}{l}\text { Formato de recibo "Tabacalera } \\
\text { Mexicana } \\
\text { Condiciones de la Piedra: fractura }\end{array}$ & $32 \times 20 \times 4.5 \mathrm{~cm}$ & 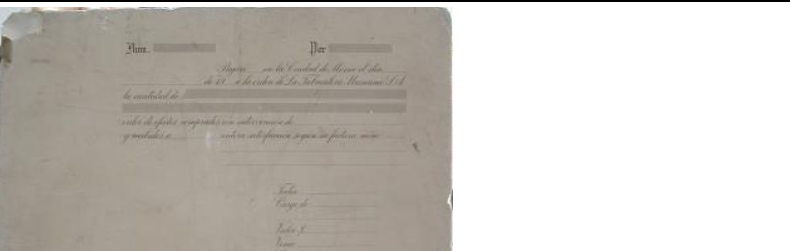 \\
\hline
\end{tabular}




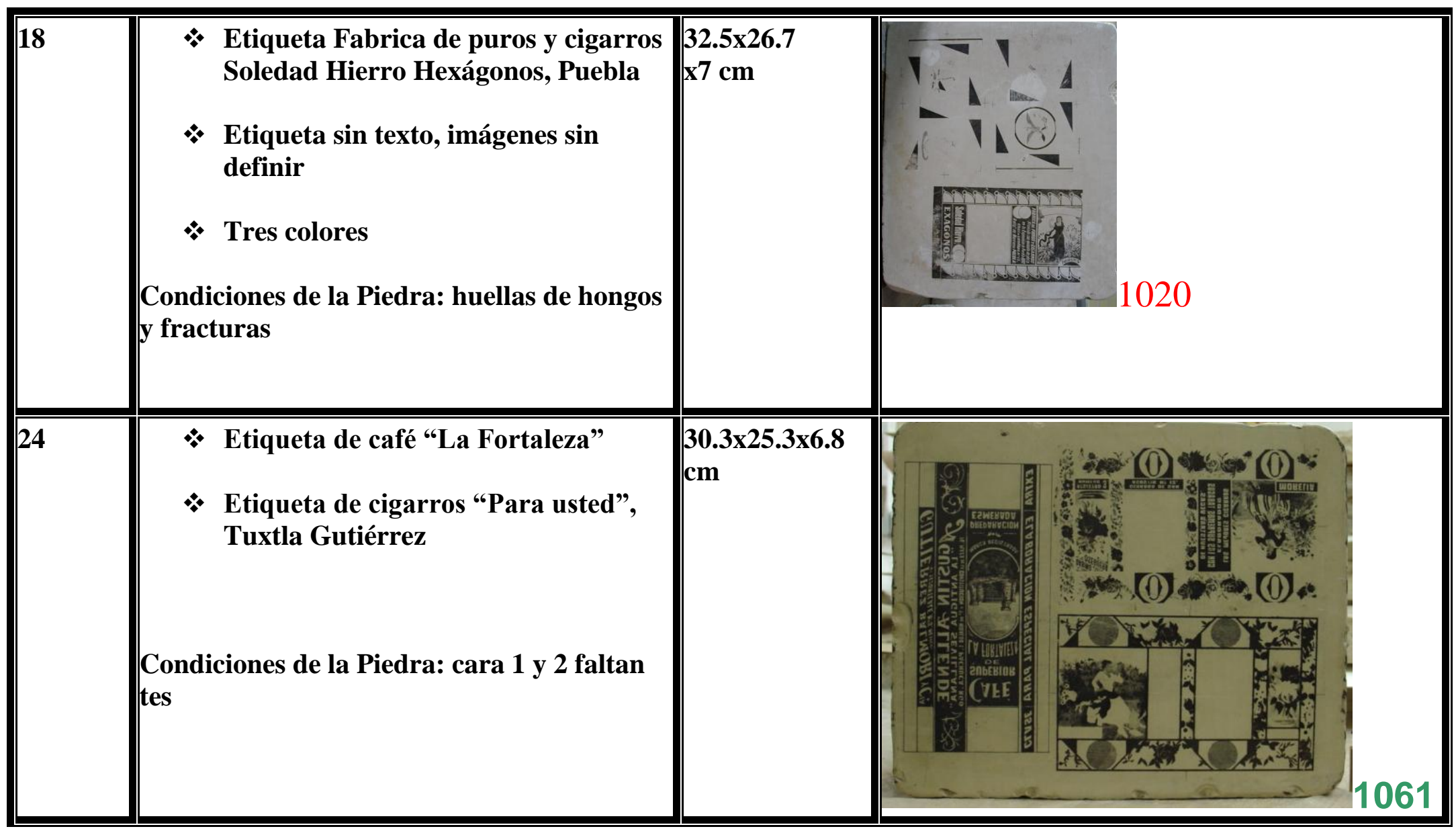




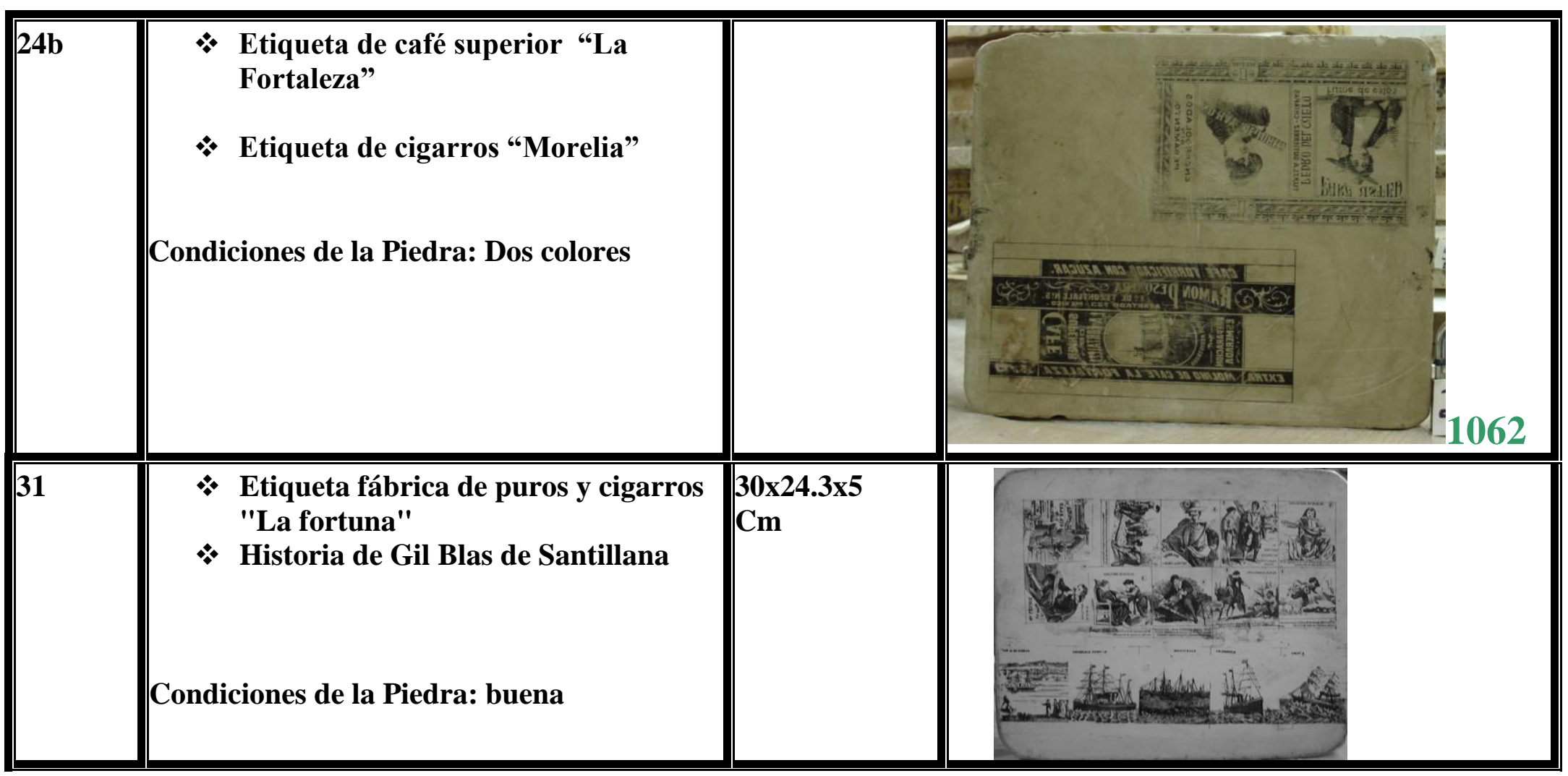




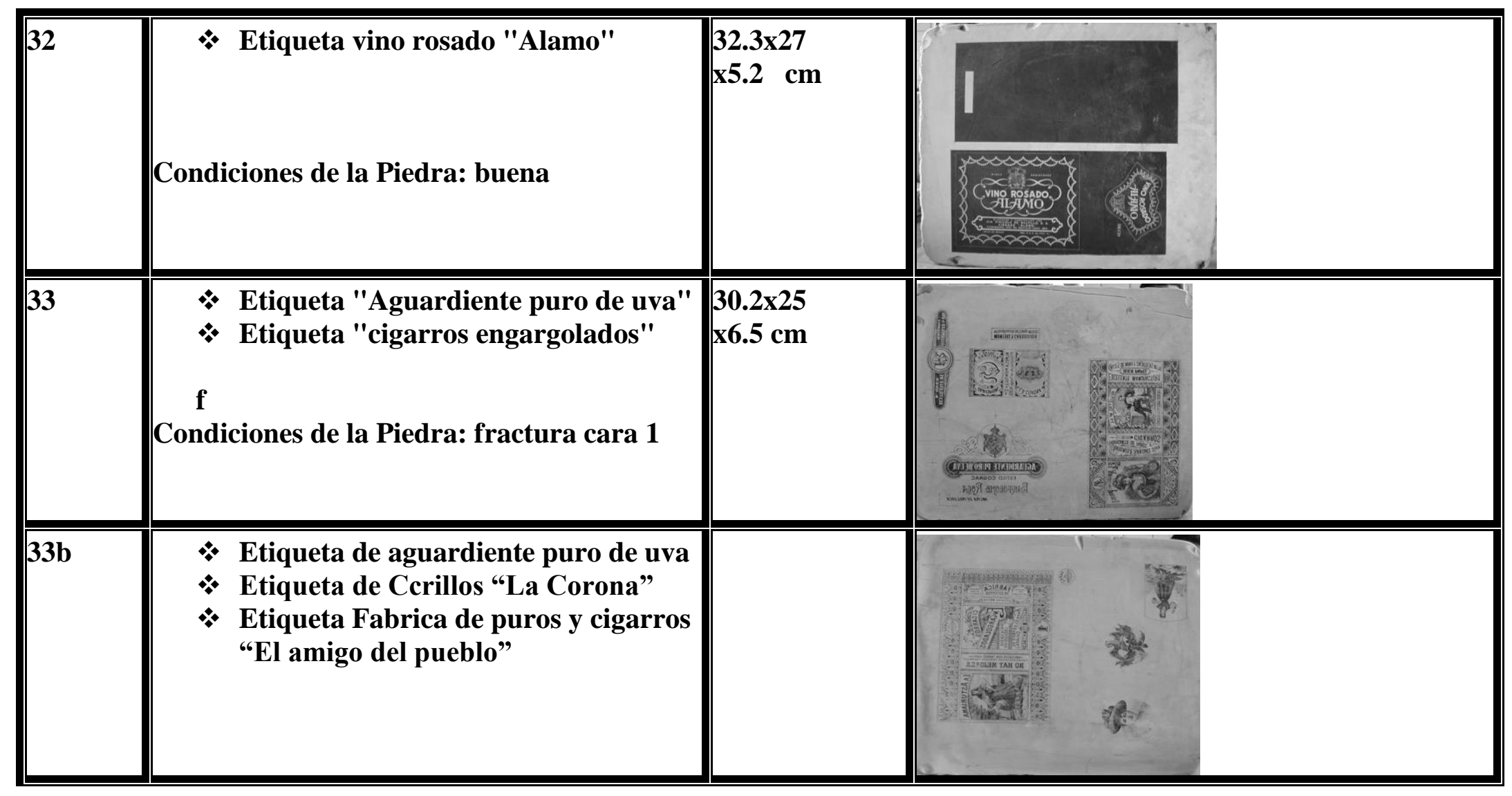




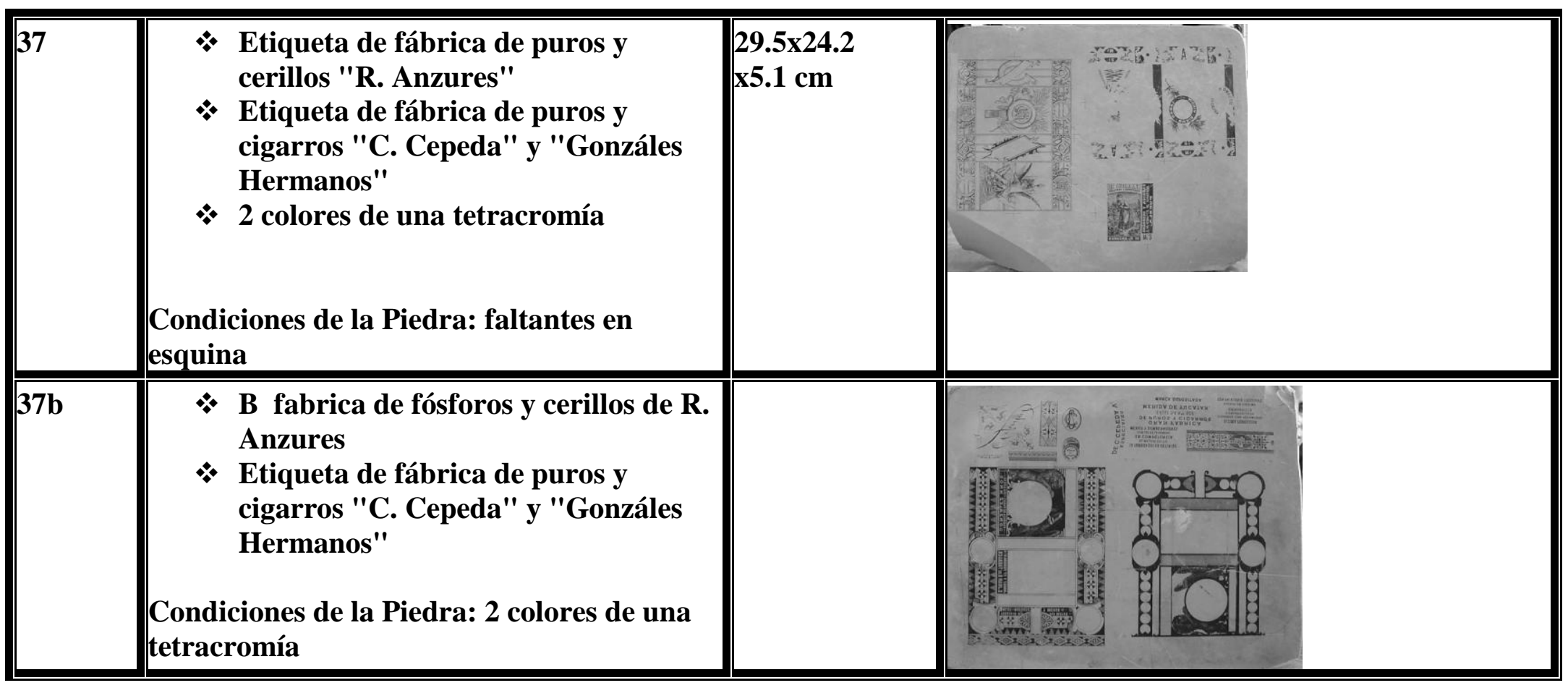




\begin{tabular}{|c|c|c|c|}
\hline 44 & $\begin{array}{l}\text { Etiquetas dibujos de una mujer } \\
\text { alada, y una mujer con fuente. } \\
\text { (Separación de color) } \\
\text { Etiqueta fábrica de cigarros "EI } \\
\text { indio triste", (separación de color) } \\
\text { Condiciones de piedra: faltante en esquina } \\
\text { superior izquierda, laminados manchas }\end{array}$ & $\begin{array}{l}32.4 \times 26.9 \\
\times 6.9 \mathrm{~cm}\end{array}$ & 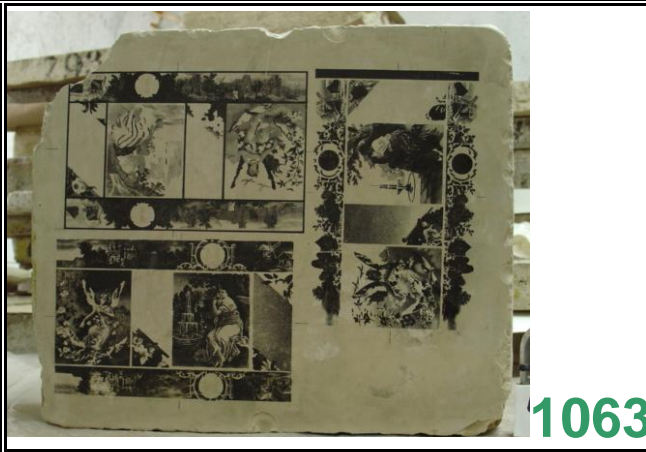 \\
\hline $44 b$ & $\begin{array}{l}\text { Etiqueta fábrica de cigarros "El } \\
\text { indio triste", (separación de color) } \\
\text { Condiciones de piedra: faltante en esquina } \\
\text { superior izquierda, laminados manchas }\end{array}$ & & 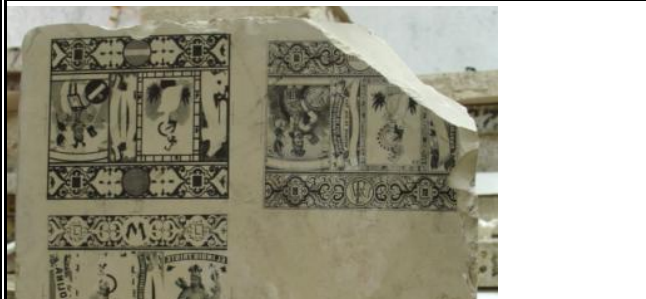 \\
\hline 47 & $\begin{array}{l}\text { * Etiqueta de cigarros "El As de oros", } \\
\text { y etiqueta de tabacos } \\
* \text { Etiquetas dibujo de flores } \\
\text { Condiciones de la Piedra: fracturas rayones } \\
\text { laminados manchas }\end{array}$ & $33 \times 27 \times 7 \mathrm{~cm}$ & 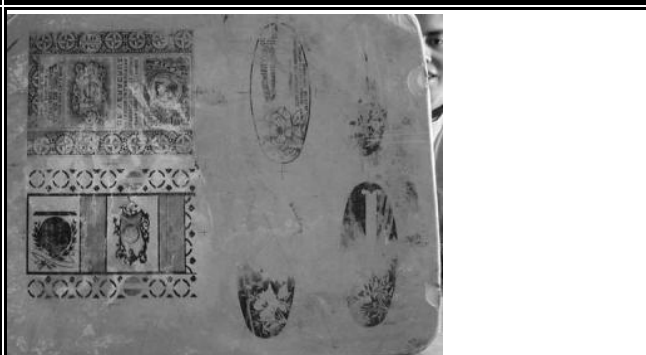 \\
\hline
\end{tabular}




\begin{tabular}{|c|c|c|c|}
\hline 51 & $\begin{array}{l}\text { Etiqueta, fabrica de puros "Carlos } \\
\text { Vudoyra } \\
\text { Dos colores } \\
\text { Condiciones de la Piedra:buena }\end{array}$ & $37.8 \times 24 \times 5.5 \mathrm{~cm}$ & $\int_{1065}$ \\
\hline 53 & $\begin{array}{l}\text { *tiqueta, fabrica de aguas gaseosas } \\
\text { "Flores" } \\
\text { *os colores } \\
\text { * Etiqueta de cigarros "La Bella } \\
\text { Unión" } \\
\text { * Dos colores } \\
\text { * Condiciones de la Piedra:buena }\end{array}$ & $30.5 \times 25 \times 5.6 \mathrm{~cm}$ & 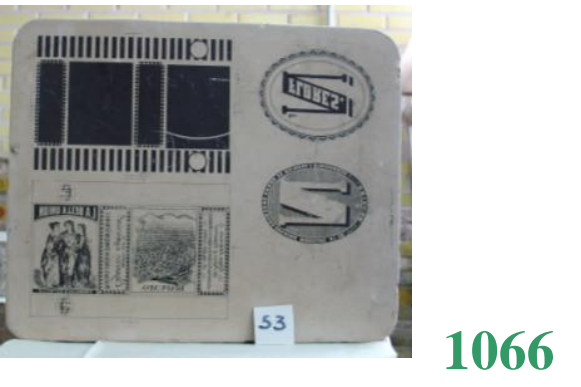 \\
\hline 57 & $\begin{array}{l}\text { Etiqueta: Gran fabrica de puros y } \\
\text { cigarros "El vapor" } \\
\text { Dos colores } \\
\text { Condiciones de la Piedra: buena }\end{array}$ & $30.5 \times 25.3 \times 5 \mathrm{~cm}$ & 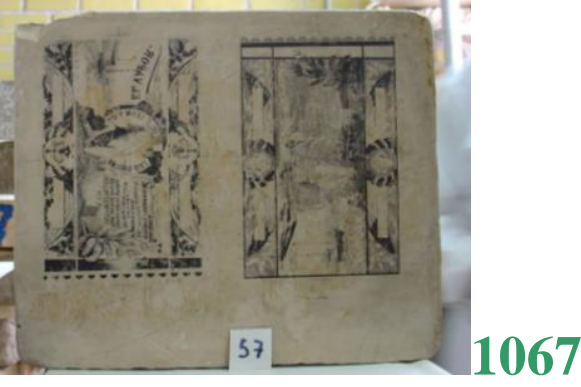 \\
\hline
\end{tabular}




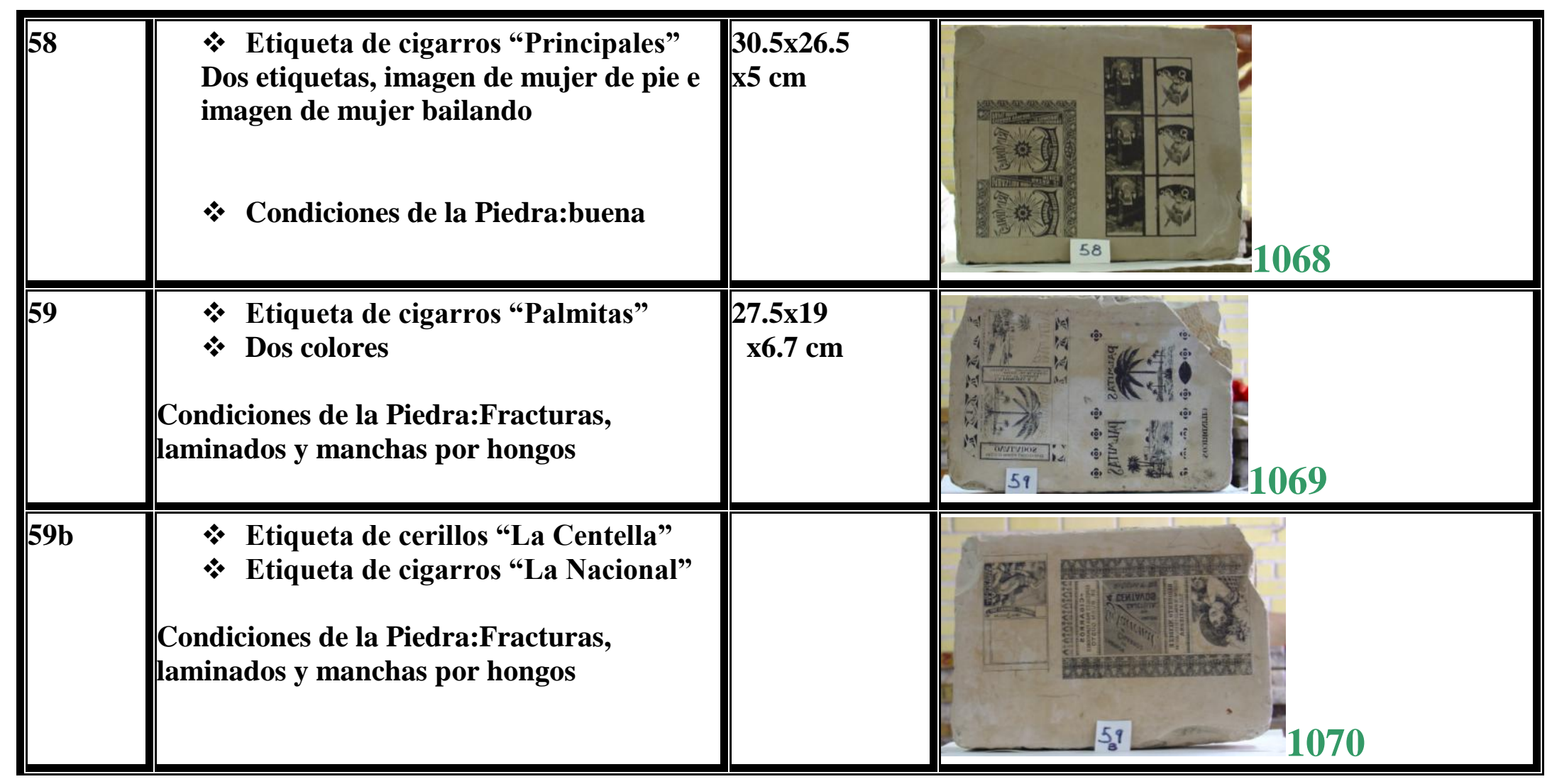




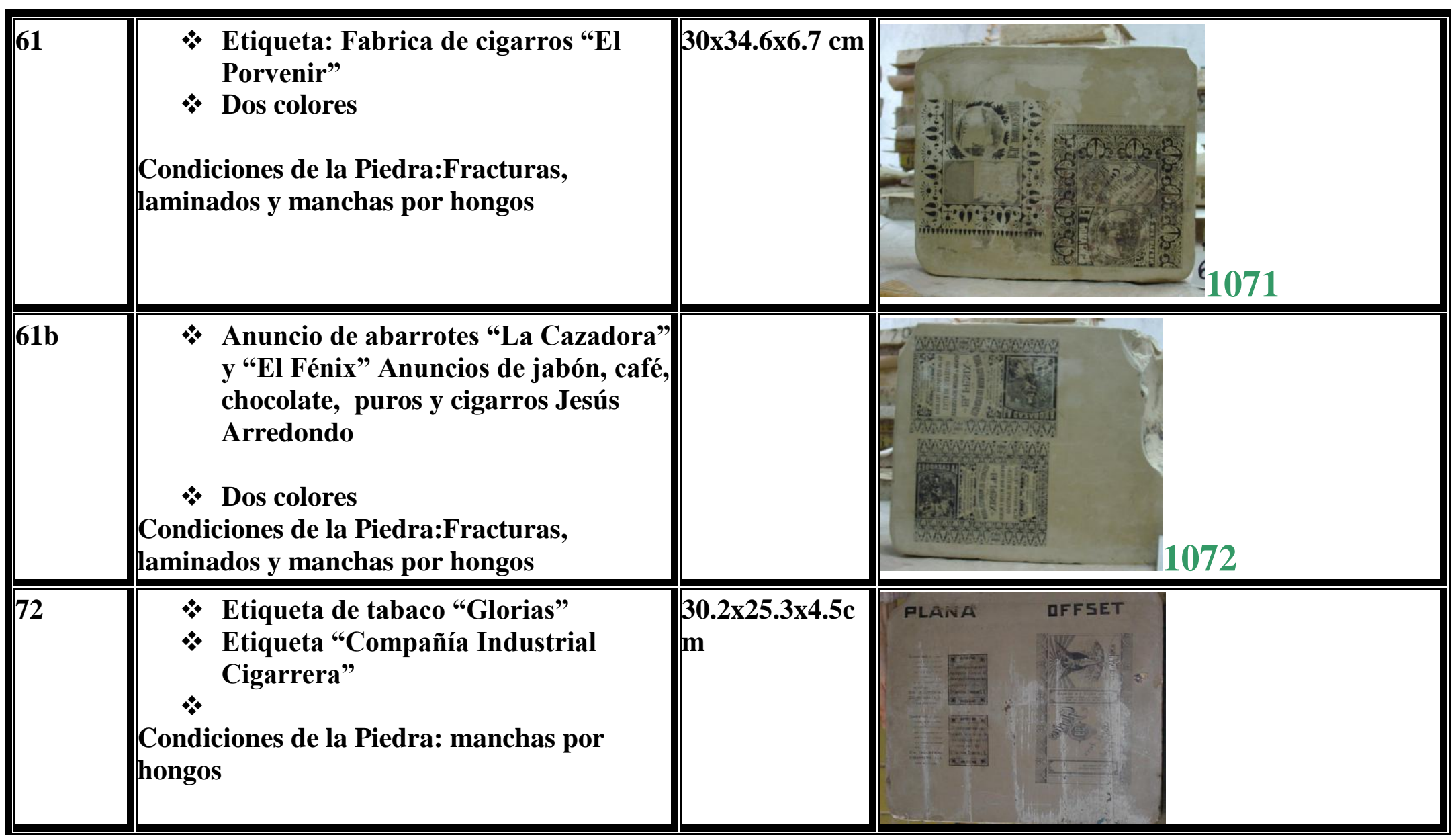




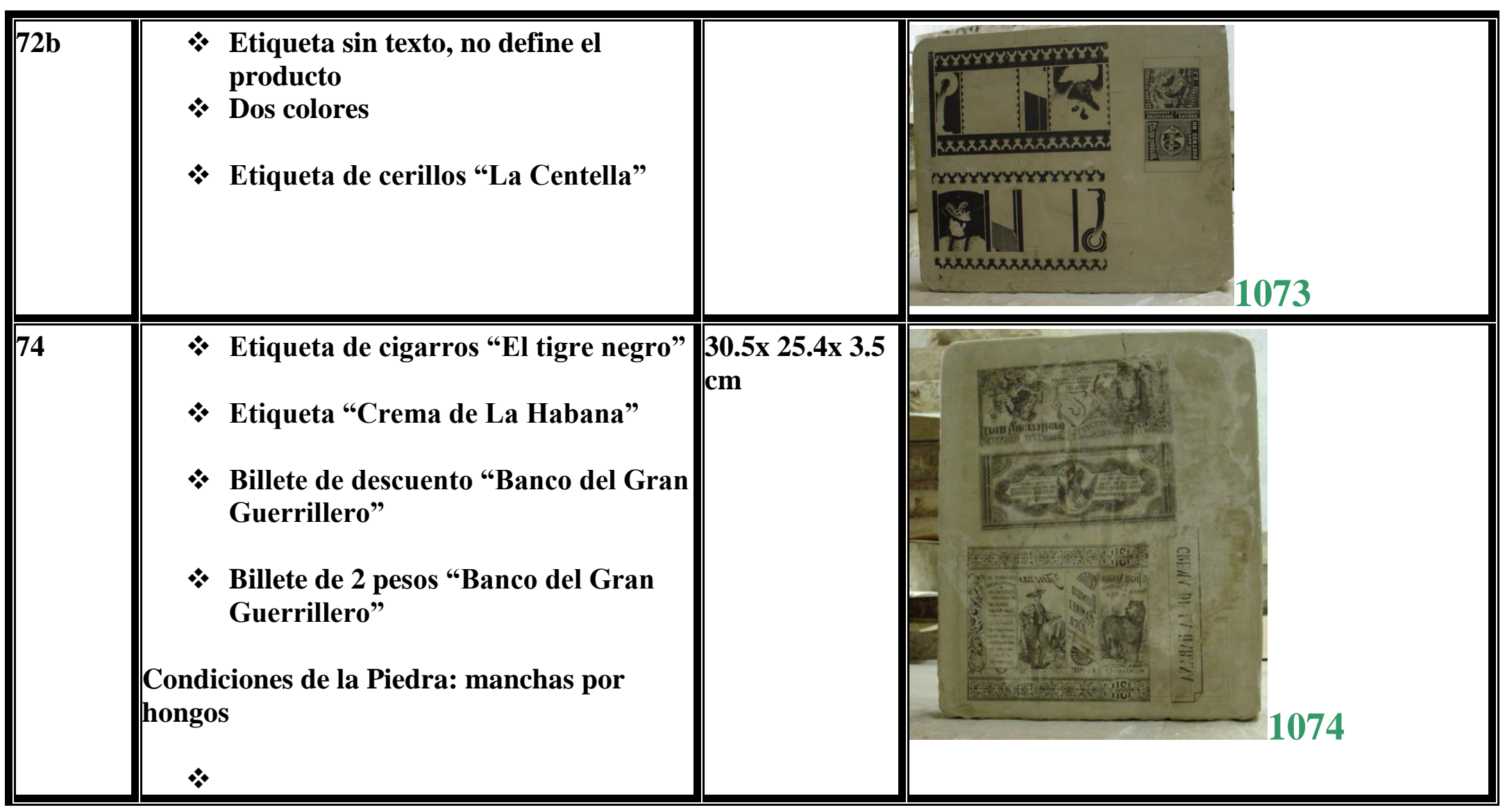




\begin{tabular}{|c|c|c|c|}
\hline $74 b$ & \begin{tabular}{|l} 
*tiqueta "Cruz Roja" \\
Tres colores \\
\\
* Etiqueta del Ayuntamiento de \\
Tehuacan \\
. Dos colores \\
Condiciones de la Piedra: buena
\end{tabular} & & 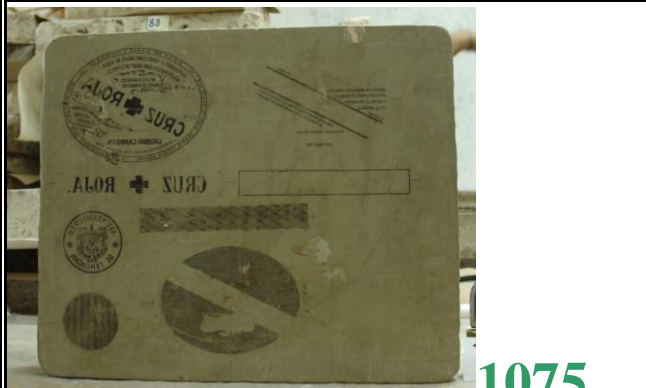 \\
\hline 76 & $\begin{array}{l}\text { Fabrica de cigarros "EI Vesubio", } \\
\text { Celaya } \\
* \text { Etiqueta de cigarros "La Nacional" } \\
* \text { Etiqueta de cerillos "La Victoria" } \\
\text { Condiciones de la Piedra: Faltantes en los } \\
\text { lados }\end{array}$ & $32.4 \times 27 \times 4.5 \mathrm{~cm}$ & 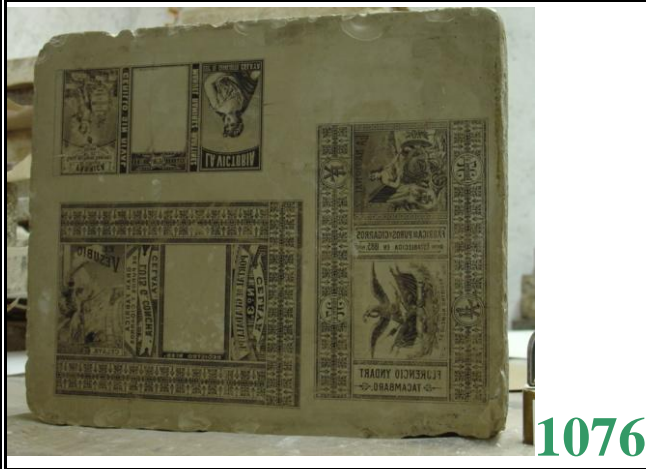 \\
\hline
\end{tabular}




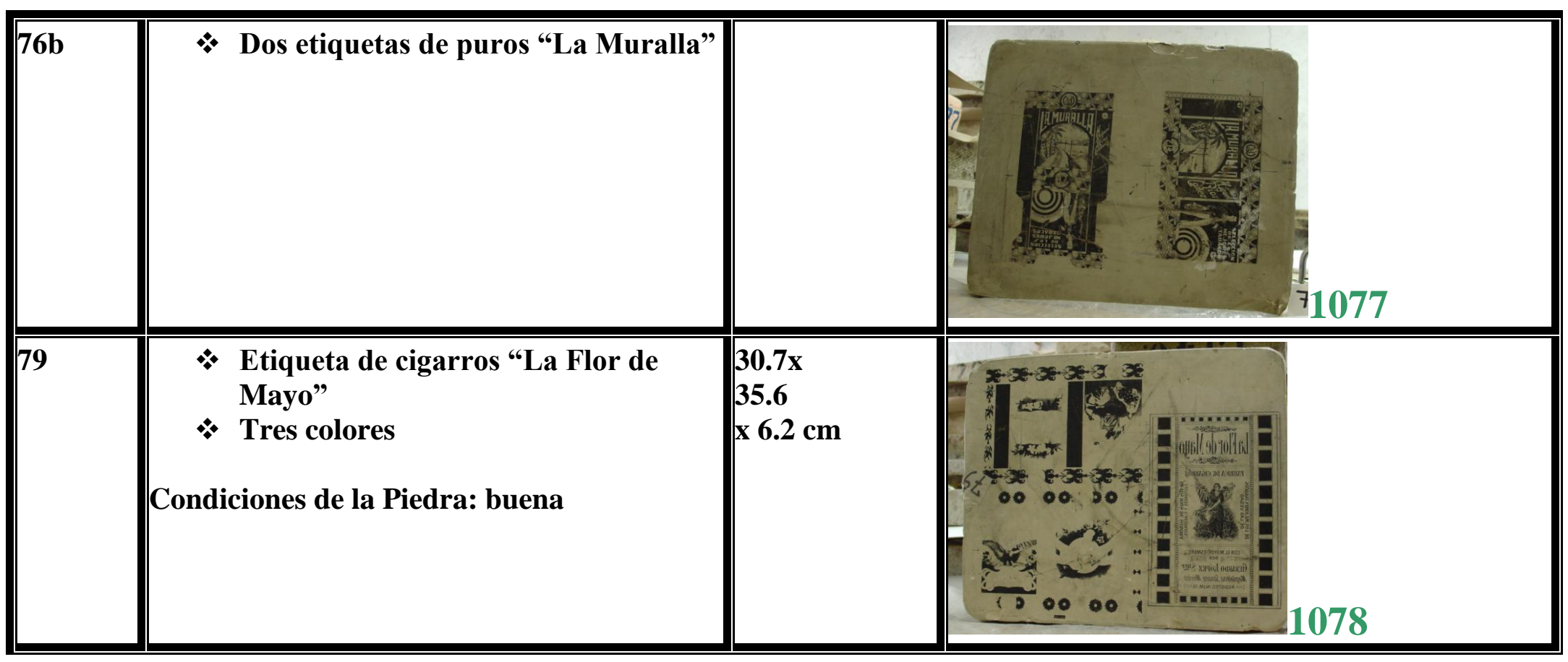




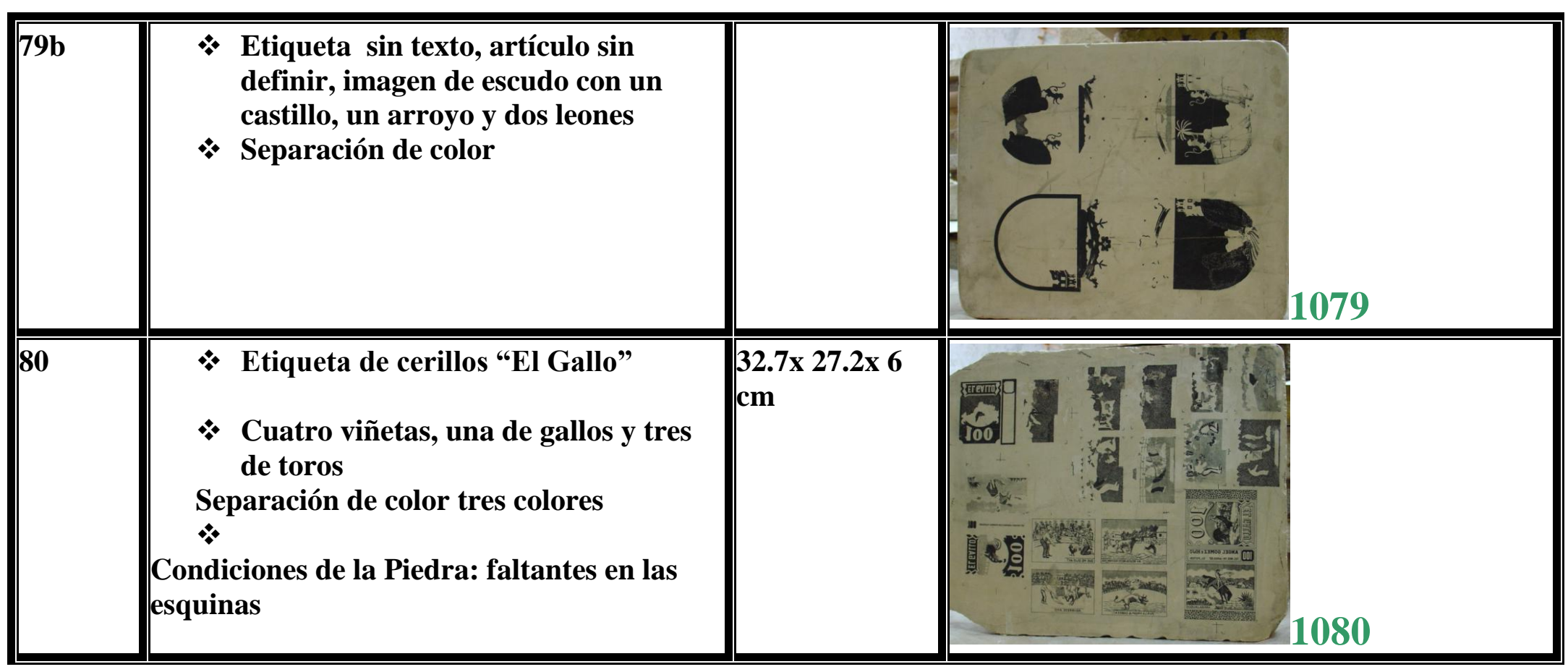




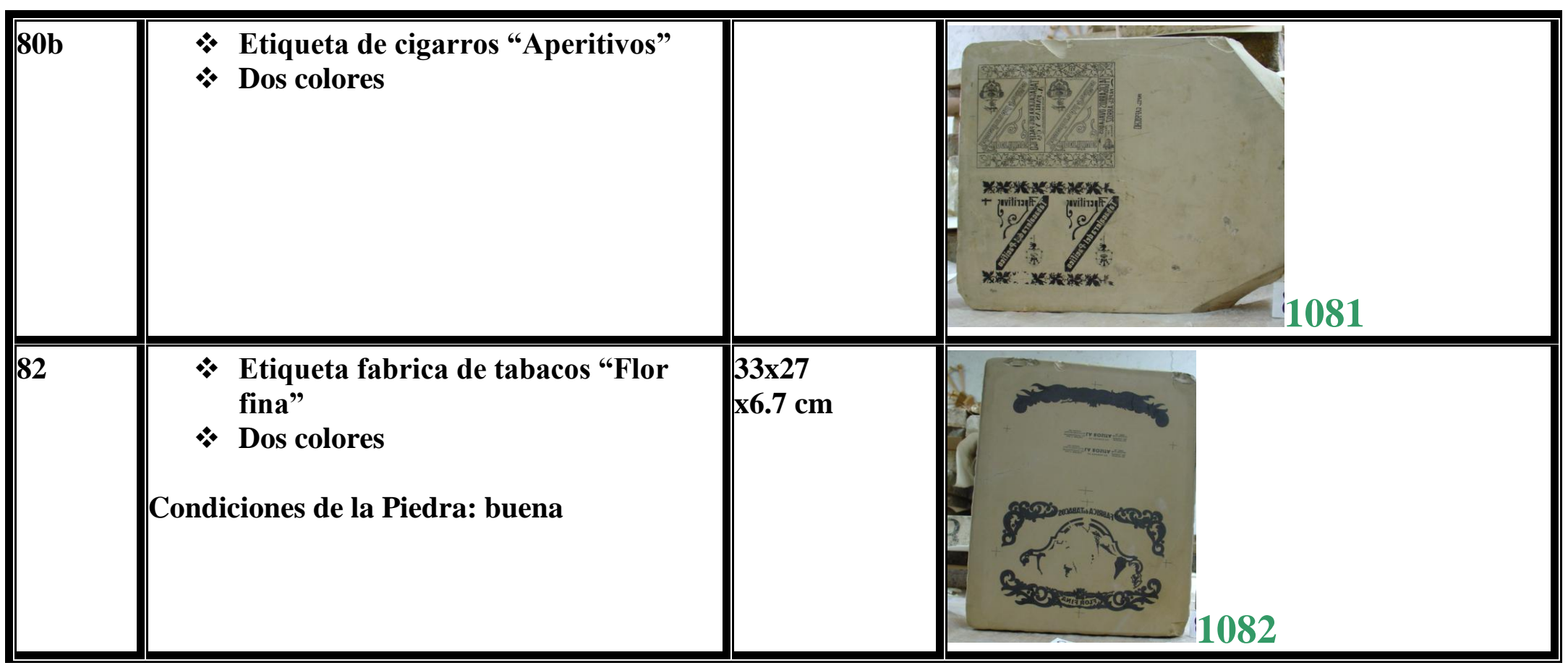




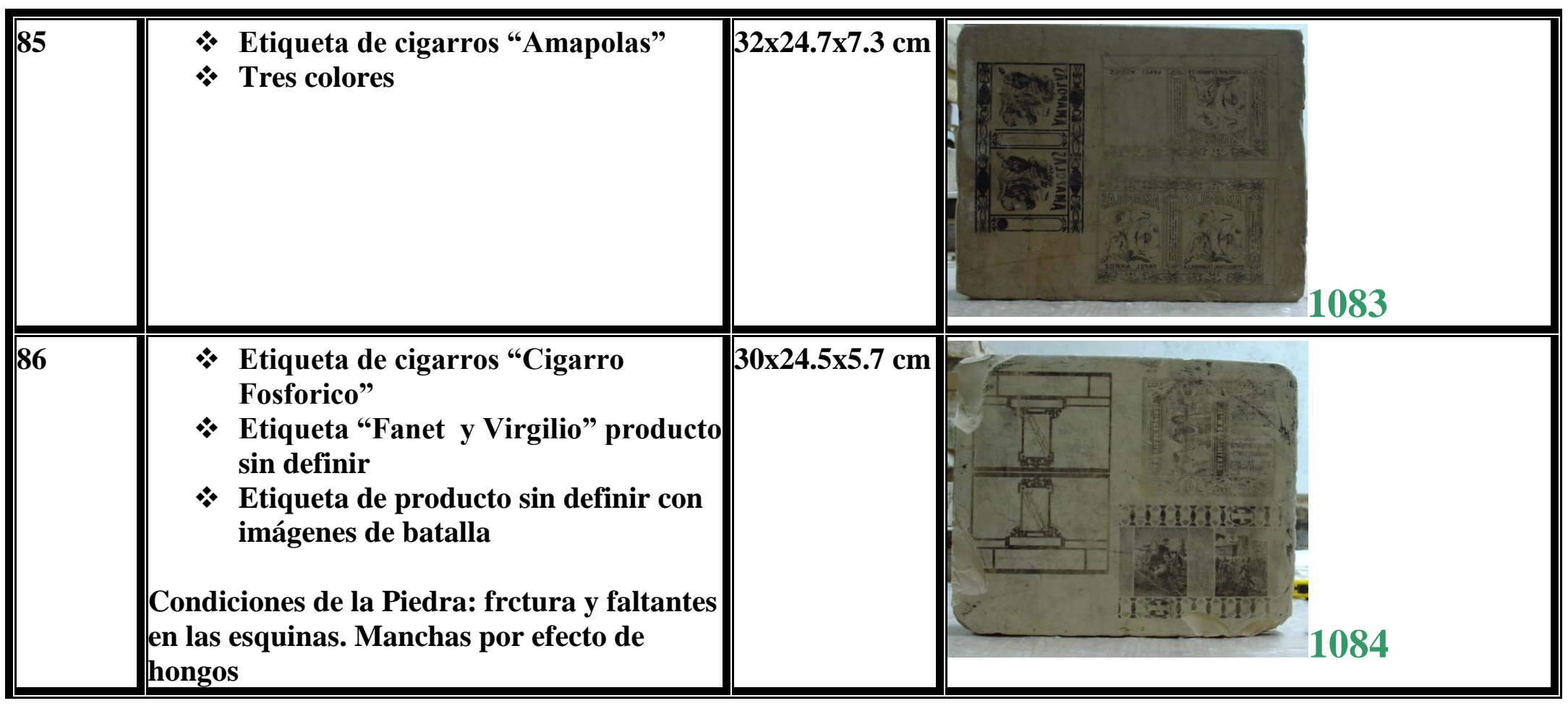




\begin{tabular}{|c|c|c|}
\hline 88 & $\begin{array}{l}\text { Etiqueta de Fábrica de puros "El } \\
\text { vapor" } \\
\text { Etiqueta de Fábrica de puros "La } \\
\text { Reforma del } 99 " \\
\text { Condiciones de la piedra: buena, pero la } \\
\text { imagen comprometida por efecto de la } \\
\text { humedad }\end{array}$ & $30.2 \times 25.5 \times 4 \mathrm{~cm}$ \\
\hline 89 & $\begin{array}{l}\text { Etiqueta de puros y cigarros "La } \\
\text { Perla Mexicana" } \\
\text { * Tres colores }\end{array}$ & $33 \times 27.5 \times 5.2 \mathrm{~cm}$ \\
\hline
\end{tabular}




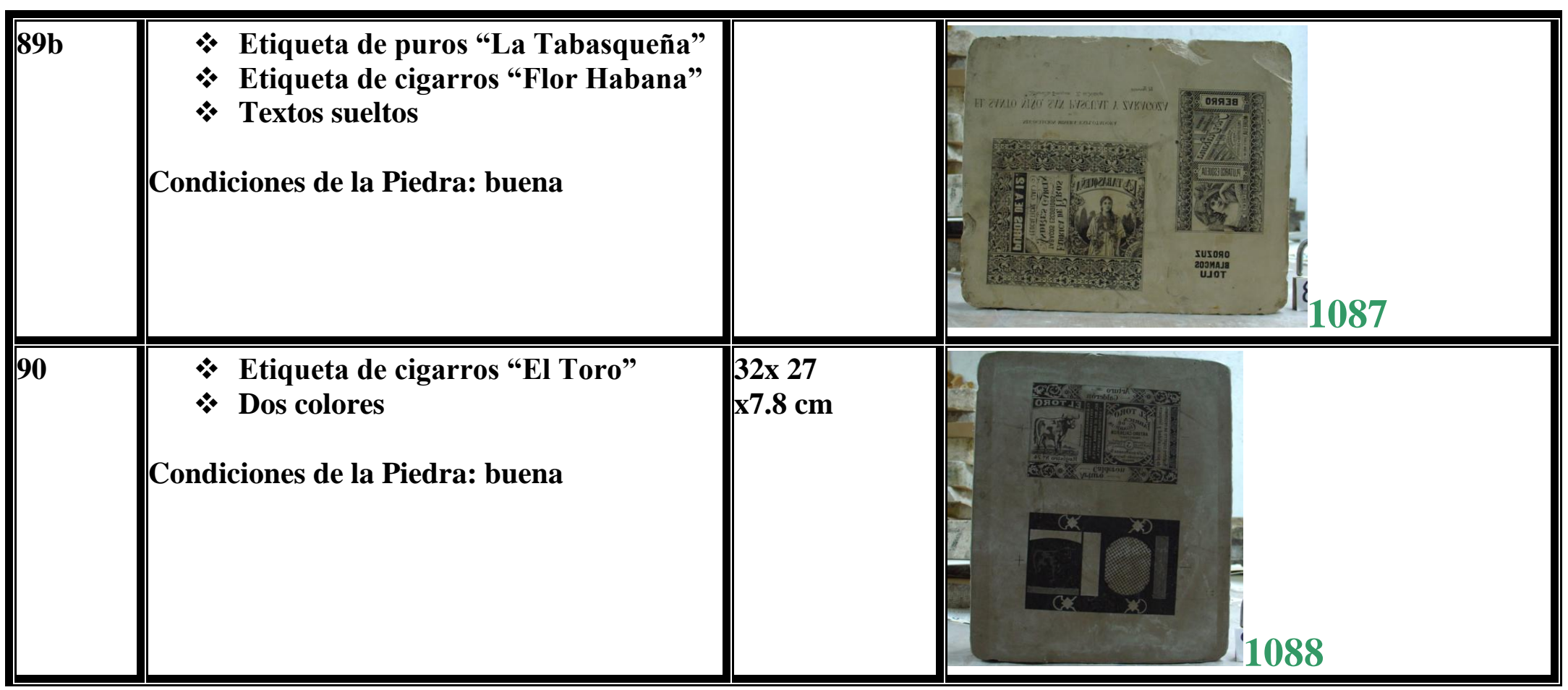




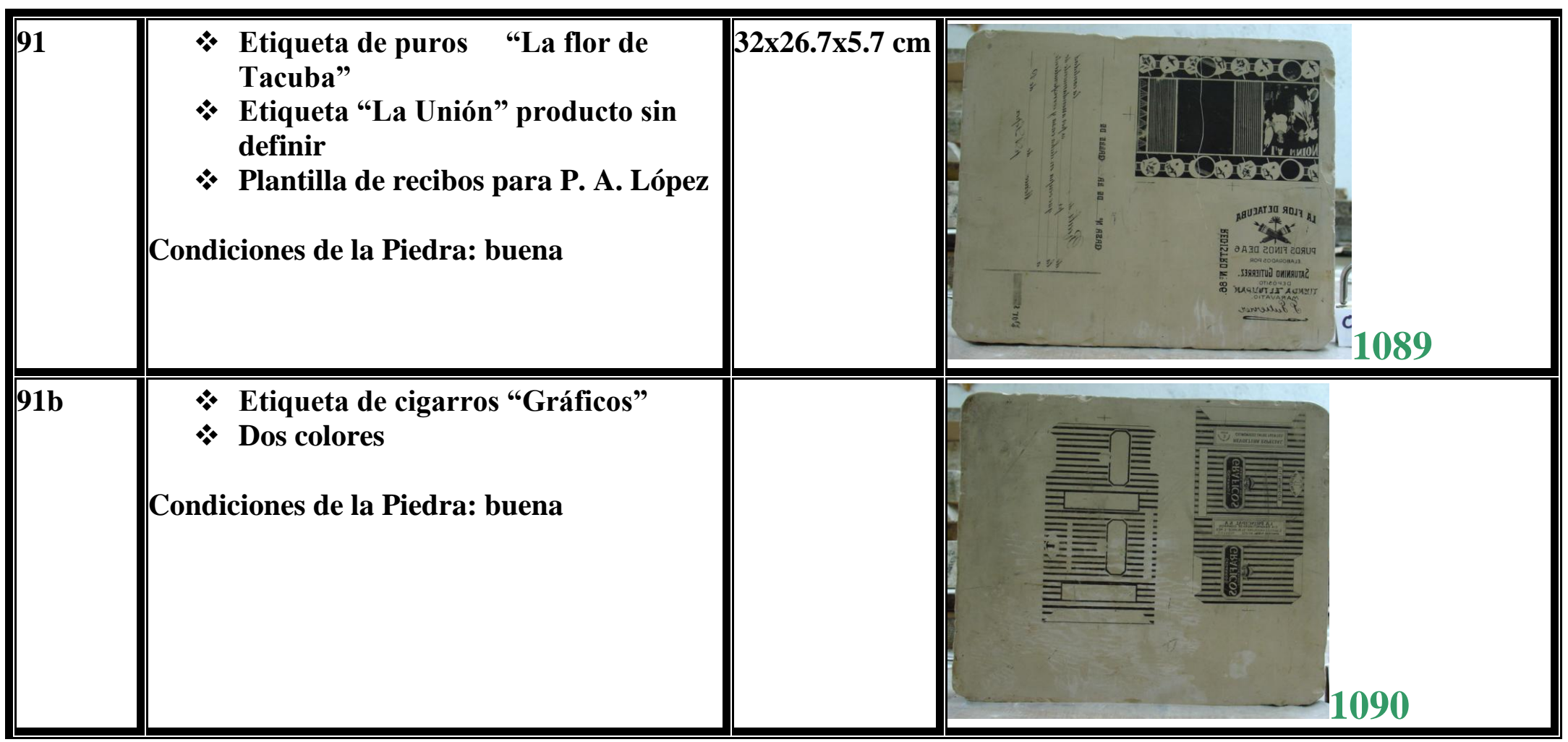




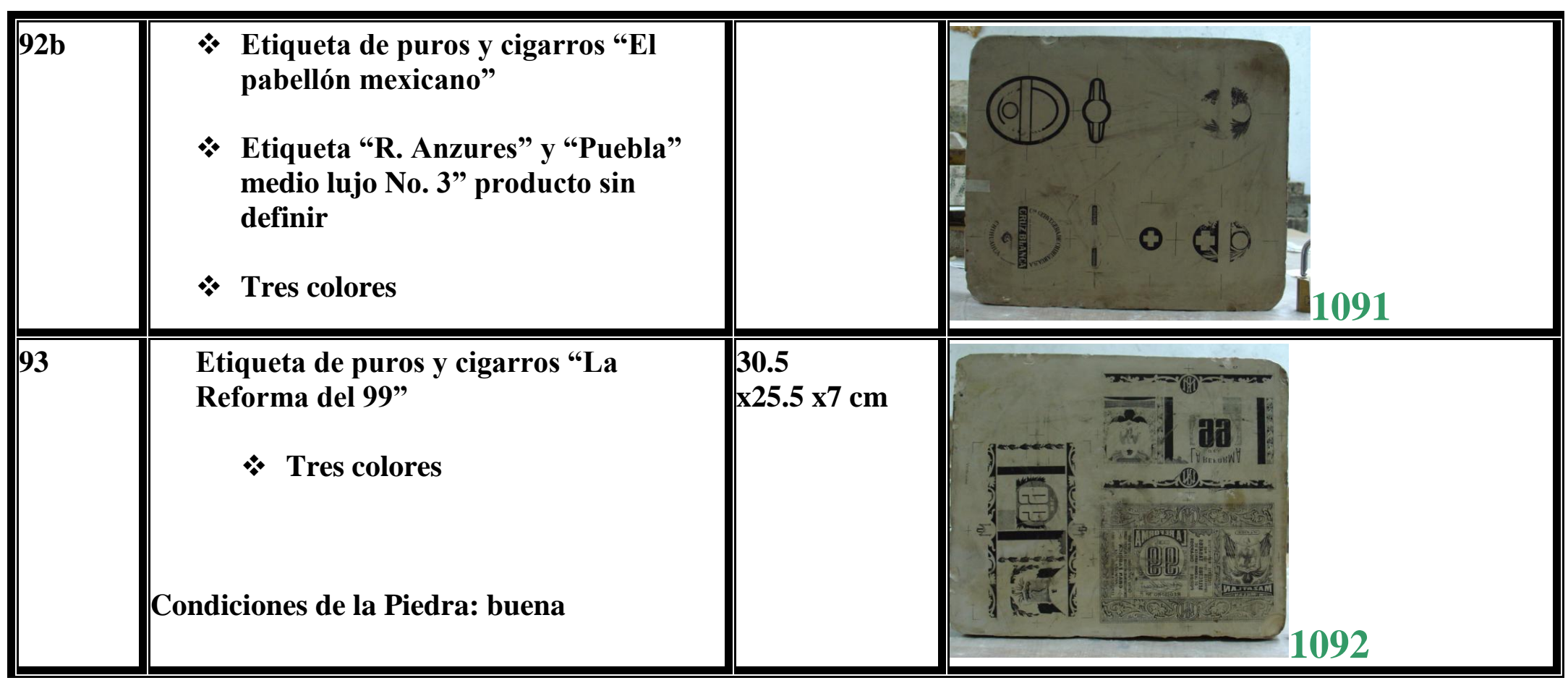




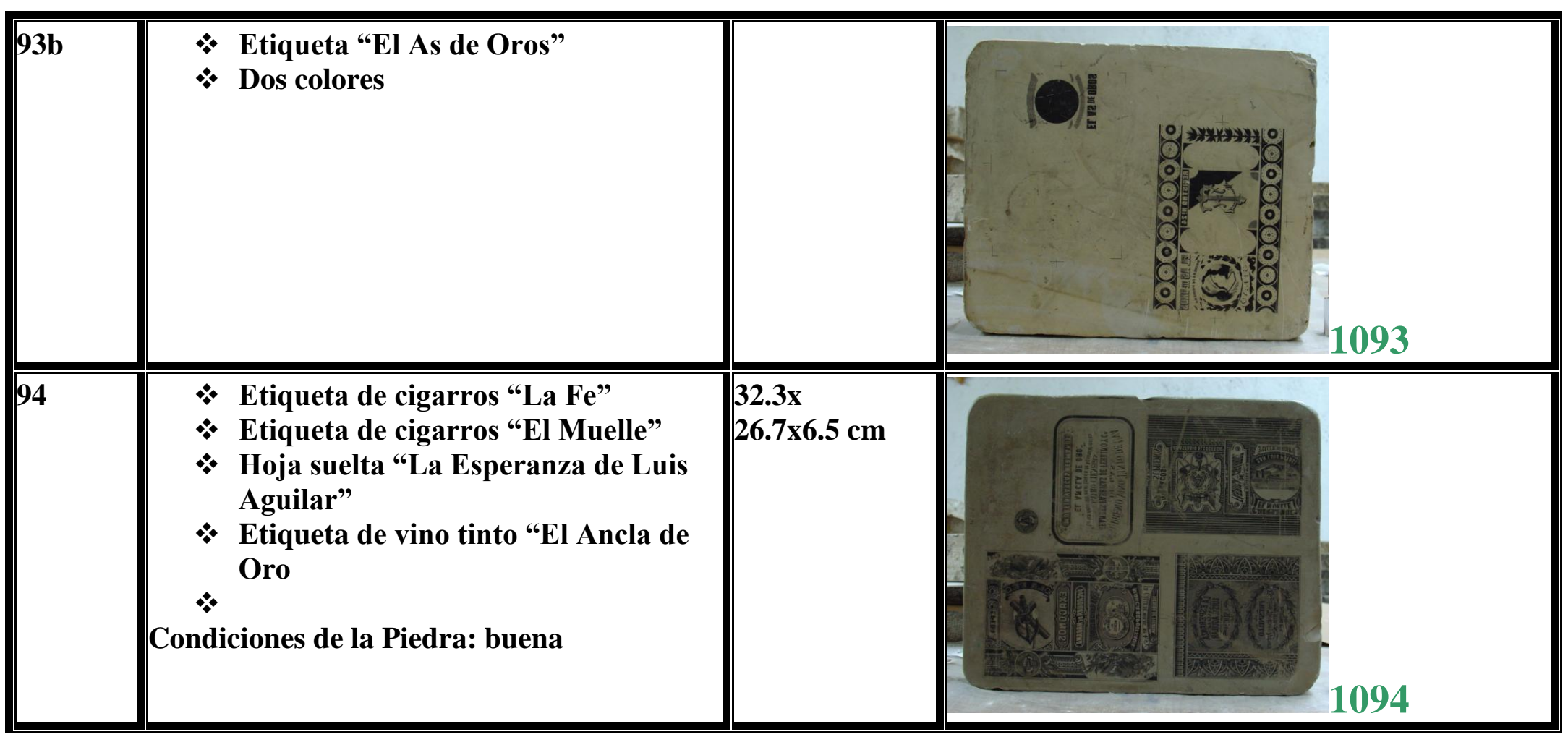




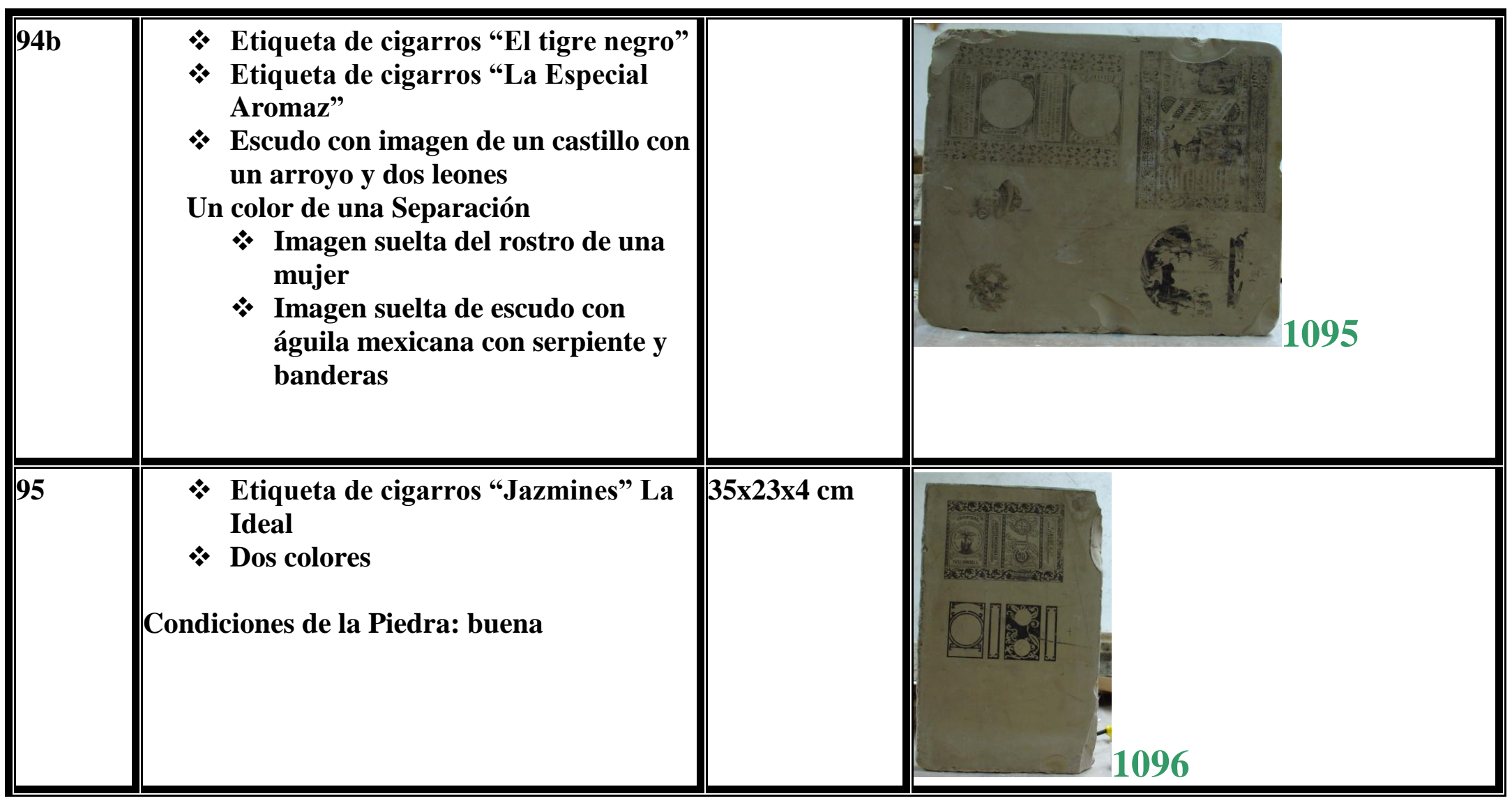




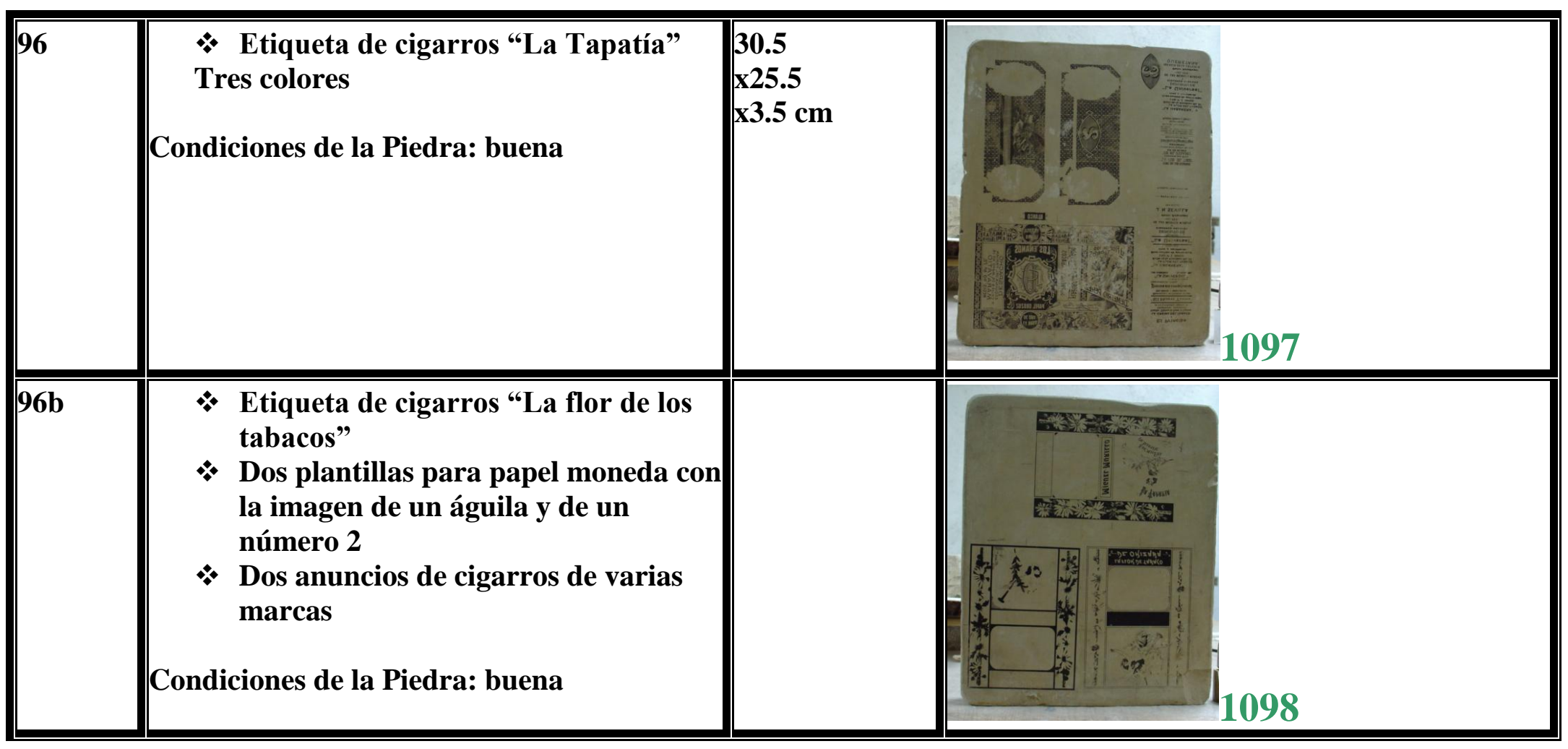




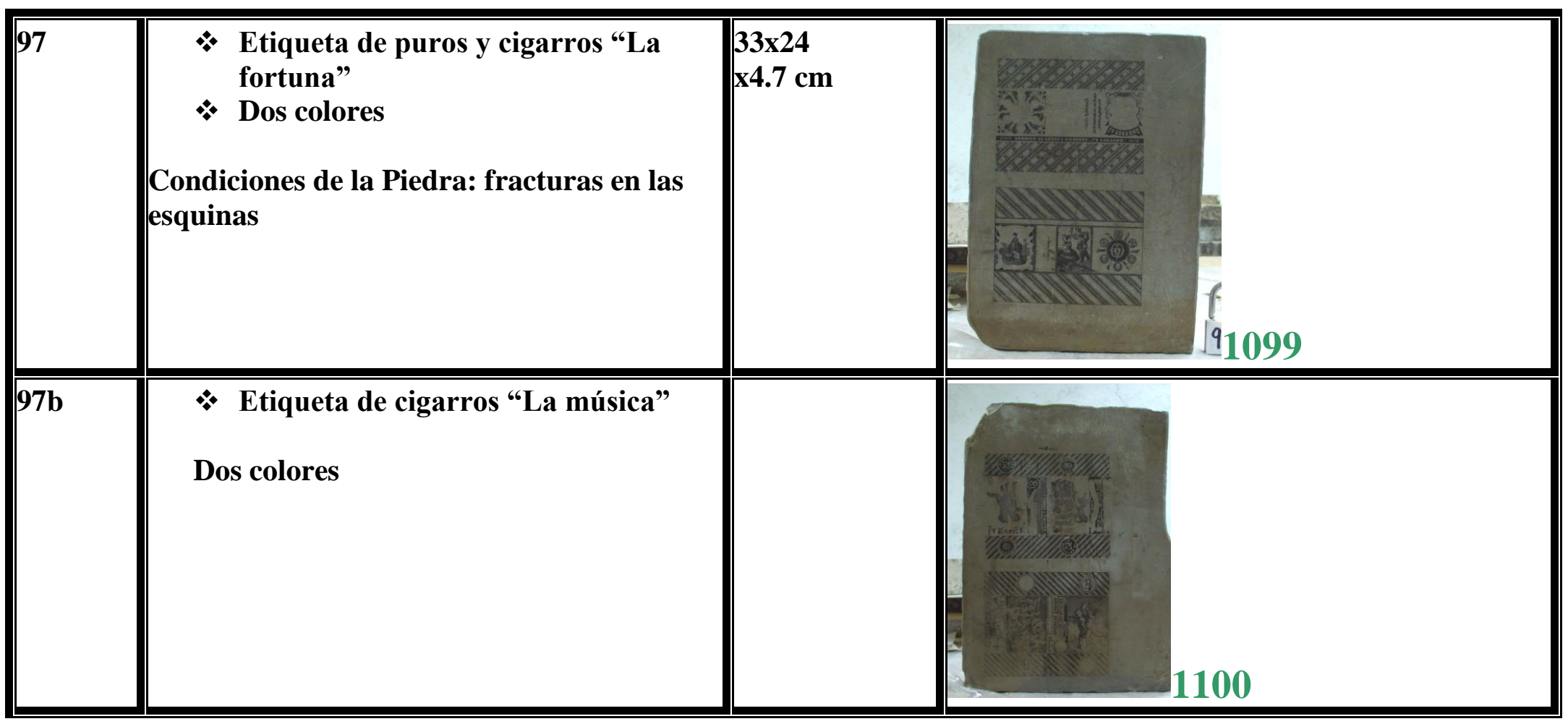




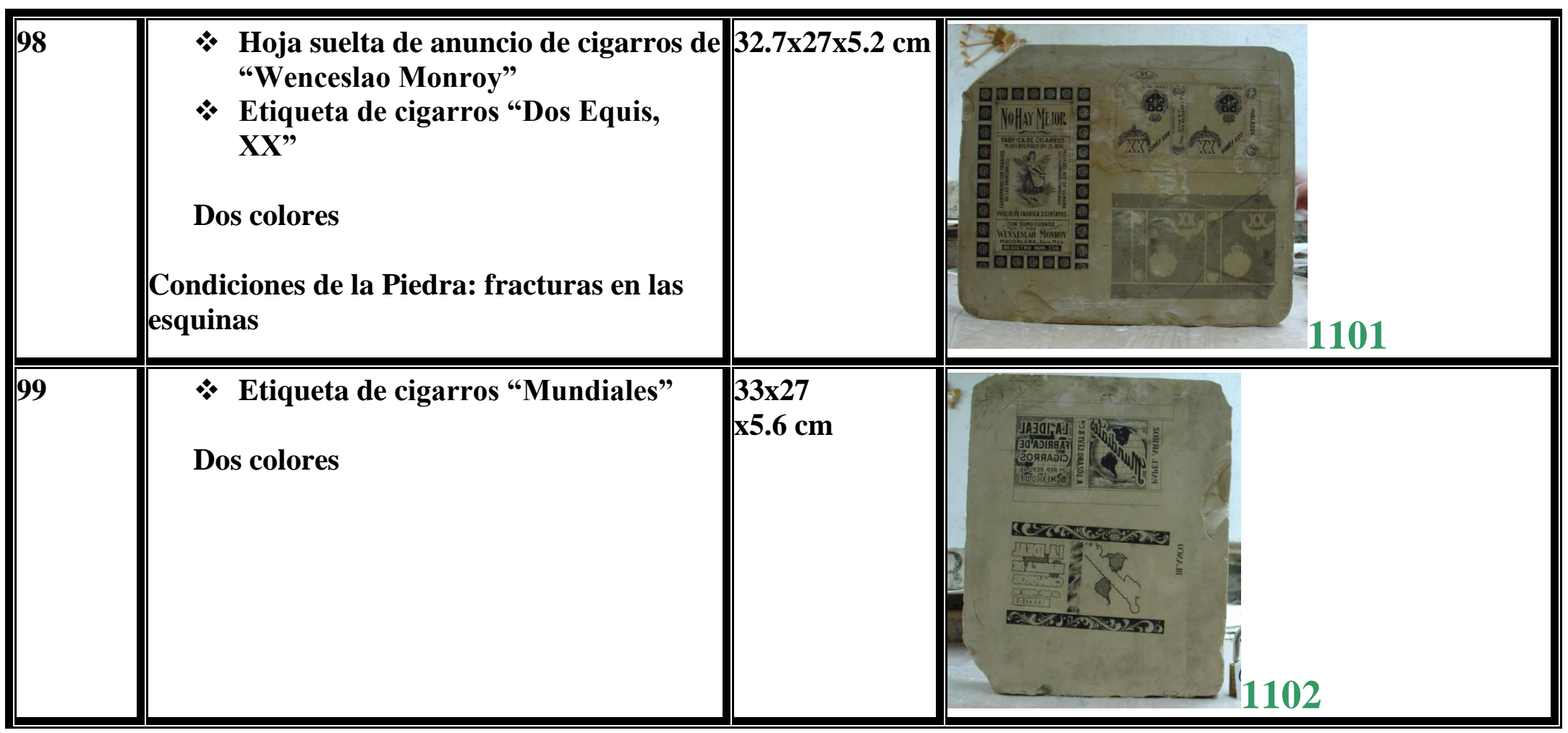




\section{ANEXO 2 CD SISTEMA}

MAYARATACIERRAELPICO 